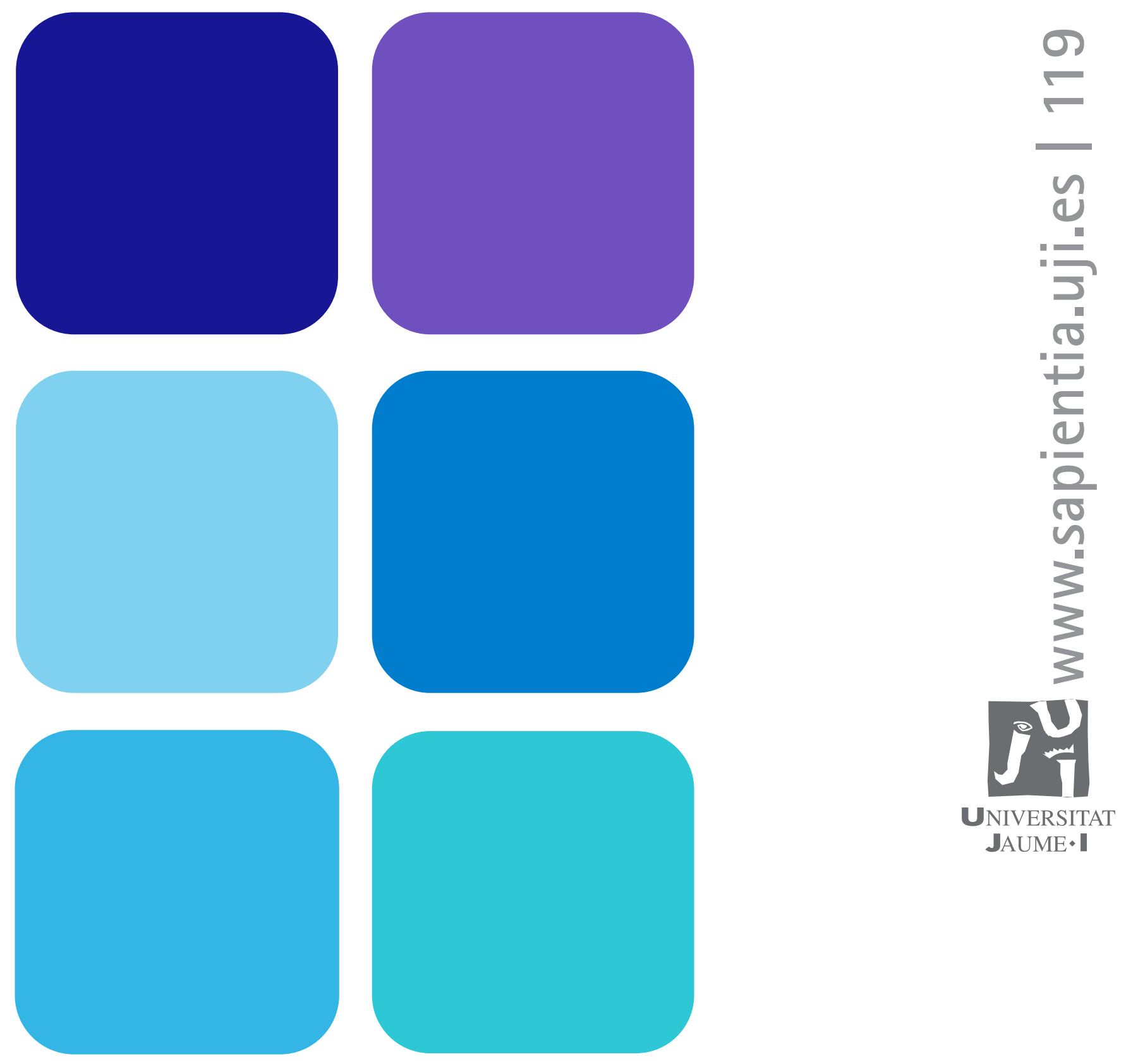

\title{
La construcció del pensament matemàtic en l'educació infantil
}

Inmaculada Pérez Serrano

Manuel Alcalde Esteban

Gil Lorenzo Valentín 


\section{La construcció del pensament matemàtic en l'educació infantil}

Inmaculada Pérez Serrano

Manuel Alcalde Esteban

Gil Lorenzo Valentín

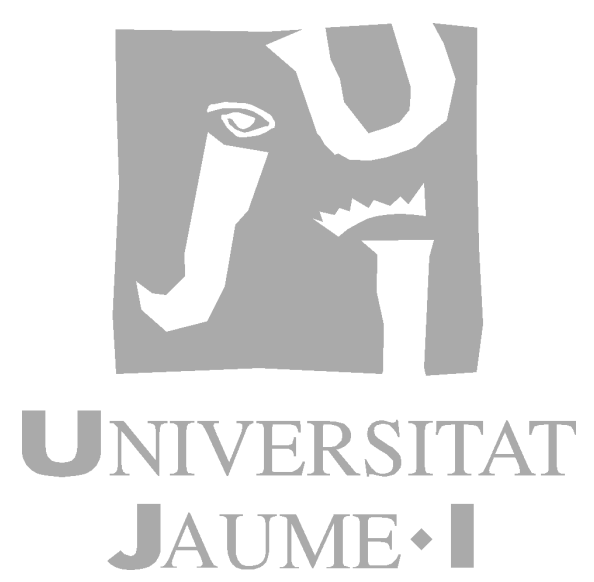

Departament d'Educació

Codi d'assignatura MI1017 
Edita: Publicacions de la Universitat Jaume I. Servei de Comunicació i Publicacions Campus del Riu Sec. Edifici Rectorat i Serveis Centrals. 12071 Castelló de la Plana http://www.tenda.uji.es e-mail: publicacions@uji.es

Col·lecció Sapientia 119

www.sapientia.uji.es

Primera edició, 2016

ISBN: 978-84-16356-95-9

urte

Uniós de EDitoriales
UnTVERStTarLas Española

Publicacions de la Universitat Jaume I és una editorial membre de l'UNE, cosa que en garanteix la difusió de les obres en els àmbits nacional i internacional. www.une.es

\section{c) (i) (2)}

Reconeixement-CompartirIgual

CC BY-SA

Aquest text està subjecte a una llicència Reconeixement-CompartirIgual de Creative Commons, que permet copiar, distribuir i comunicar públicament l'obra sempre que s'especifique l'autoria i el nom de la publicació fins i tot amb objectius comercials i també permet crear obres derivades, sempre que siguen distribuïdes amb aquesta mateixa llicència.

http://creativecommons.org/licenses/by-sa/3.0/legalcode

Aquest llibre, de contingut cientific, ha estat avaluat per persones expertes externes a la Universitat Jaume I, mitjançant el mètode denominat revisió per iguals, doble cec. 


\section{ÍNDEX}

Introducció

Tema 1. Desenvolupament dels conceptes lògics

1. Introducció

1.1. Històrica

1.2. Al tema

2. Formalització dels conceptes de la teoria de conjunts

2.1. Introducció

2.2. Conjunts

2.2.1. Definicions i conceptes bàsics

2.2.2. Operacions entre conjunts

2.3. Correspondències

2.4. Relacions binàries

3. Els conceptes lògics a l'aula d'infantil

3.1. Consideracions prèvies

3.2. Capacitats per desenvolupar a l'aula d'infantil.

3.3. Desenvolupament de les capacitats.

Tema 2. Els nombres naturals en l'educació infantil

1. Introducció

1.1. Reflexió sobre el concepte de nombre natural

1.2. Contextos i usos del nombre natural

2. Formalització del conjunt dels nombres naturals.

2.1. Definició de nombre natural.

2.2. Operacions en $N$.

2.3. Ordre en $N$

3. Sistemes de numeració

3.1. Evolució històrica

3.2. Definició i tipus

3.2.1. Sistemes de numeració additius

3.2.2. Sistemes de numeració posicionals

4. Els nombres naturals a l'aula d'infantil

4.1. Consideracions prèvies

4.2. Capacitats per desenvolupar a l'aula d'infantil

4.3. Desenvolupament de les capacitats.... 
Tema 3. Càlcul operacional en l'eduació infantil

1. Introducció

1.1. Reflexió general sobre les operacions a l'escola.

2. El càlcul operacional a l'aula d'infantil

2.1. Consideracions prèvies

2.2. Capacitats a desenvolupar a l'aula d'infantil

2.3. Desenvolupament de les capacitats....

Tema 4. Iniciació a la mesura

1. Introducció

1.1. Històrica

2. Formalització dels conceptes de magnitud i mesura

2.1. Concepte de magnitud.

2.2. Mesura d'una magnitud.

2.3. Unitat de mesura

3. La iniciació a la mesura a l'aula d'infantil.

3.1. Consideracions prèvies

3.2. Capacitats a desenvolupar a l'aula d'infantil

3.3. Desenvolupament de les capacitats....

Tema 5. Primeres nocions espacials i geomètriques

1. Introducció

1.1. Històrica

1.2. Al tema

2. Els primers passos per la geometria

2.1. Preliminars

2.2. Geometries

2.3. Referents psicoevolutius

3. Introducció teòrica .

3.1. Línies en el pla

3.1.1. Antecedents: pla, punts i vectors

3.1.2. La recta

3.1.3. La circumferència

3.2. Superfícies en el pla

3.2.1. Angles

3.2.2. Polígons

3.2.2.1. Triangles

3.2.2.2. Quadrilàters

3.2.2.3. Pentàgons

3.2.2.4. Hexàgons

3.2.3. Consideracions sobre els polígons

3.2.3.1. Mosaics

3.2.3.2. Polígons regulars: simetries

3.2.4. Cercle

3.3. Figures en l'espai

3.3.1. Angles en l'espai

3.3.2. Cossos geomètrics 
3.3.2.1. Políedres

3.3.2.2. Cossos redons

3.4. Transformacions geomètriques en el pla

3.4.1. Moviments rígids o isometries

3.4.1.1. Translacions.

3.4.1.2. Girs o rotacions

3.4.1.3. Simetries axials

3.4.1.4. Composició de moviments en el pla

3.4.2. Transformacions equiformes

3.4.2.1. Proporcionalitat de segments

3.4.2.2. Teorema de tales

3.4.2.3. Homotècies

3.4.2.4. Semblances

3.5. Transformacions geomètriques en l'espai

3.5.1. Simetria especular

4. La iniciació a la geometria a l'aula d'infantil

4.1. Capacitats per desenvolupar a l'aula d'infantil

4.2. Desenvolupament de les capacitats.

Referències bibliogràfiques.

Bibliografia recomanada

Índex de figures 


\section{Introducció}

Presentem en aquest document un material per a la formació inicial i permanent del professorat d'educació infantil, on es mostren propostes didàctiques per treballar els continguts matemàtics en aquesta etapa educativa, que es concreten en conceptes lògics, iniciació als nombres naturals i a les operacions d'addició i subtracció, primeres experiències de mesura i relacions amb l'espai i la geometria.

Encara que els esmentats continguts estan treballats en publicacions d'altres autors, en aquesta pretenem oferir-los als nostres lectors en un text estructurat al voltant de les capacitats matemàtiques que cal treballar amb l'alumnat d'educació infantil.

Cadascun dels temes compta amb una introducció que ens permet reflexionar respecte de dues qüestions que considerem importants. Una és l'evolució històrica dels continguts corresponents i l'altra és l'aspecte teòric d'aquests conceptes, que s'exposa per tal de recordar-los i apropar-los al lector.

A continuació, com a part més important del text i com a nucli que justifica aquesta publicació, s'inclou en cada tema un extens apartat referent al tractament didàctic dels continguts d'educació infantil per tal de treballar-los a l'aula i aconseguir, d'aquesta manera, el desenvolupament del pensament lògico-matemàtic de l'alumnat. Els esmentats continguts s'ajusten al currículum establert en la legislació vigent per aquesta etapa educativa.

En l'apartat didàctic es presenten els esmentats continguts a partir de la realitat $i$ per a ser aplicats en ella. Com a conseqüència i atorgant-li la importància màxima a aquesta qüestió, totes les situacions que s'enuncien acompanyant els aspectes didàctics del text formen part d'altres més complexes que es treballen a l'aula, en les quals els conceptes matemàtics són essencials per a la seua interpretació $i$ resolució. De vegades les activitats matemàtiques sorgiran del desenvolupament d'alguns projectes de treball globalitzats, en altres ocasions es plantejaran a partir de les necessitats que generen les diferents àrees del currículum. Sols quan es detecten alguns continguts que no hagen aparegut en cap activitat com les esmentades abans, el docent afavorirà de manera intencionada l'aparició de situacions que provoquen les incògnites que els portaran al seu descobriment.

En tots els casos caldrà partir de les idees prèvies de l'alumnat sobre cadascun dels conceptes a treballar i, en particular, de les seues propostes personals per a resoldre les diferents situacions que s'hi plantegen. En alguns moments ens aproparem als procediments generals de conceptualització com a forma d'iniciar-los en el descobriment i la construcció de les eines matemàtiques que socialment s'utilitzen en les situacions en què intervenen.

Atenent les recomanacions del Parlament Europeu i del Consell d'Europa sobre les competències clau per a l'aprenentatge permanent, entenem que la competència matemàtica sols es concreta i cobra sentit en la mesura que els elements $i$ 
raonaments matemàtics que s'estudien són utilitzats per enfrontar-se a aquelles situacions quotidianes que els necessiten. Per això, el seu desenvolupament a l'escola s'aconseguirà partint d'una àmplia varietat d'activitats reals, derivades d'altres camps del coneixement, de les situacions habituals que es donen a l'aula i de les pròpies experiències i vivències de l'alumnat. En l'etapa d'educació infantil es tracta d'aconseguir que els xiquets i les xiquetes s'inicien en l'aplicació de les destreses i actituds que els permetran, en les etapes educatives posteriors, raonar matemàticament, comprendre una argumentació matemàtica i expressar-se $\mathrm{i}$ comunicar-se en llenguatge matemàtic per a donar una millor resposta a les situacions de la vida de diferent nivell de complexitat (Alsina, 2004, 2011a, b).

L'objectiu d'aquest material és proporcionar una eina per als professionals de la docència i per l'estudiantat del Grau en Mestre/a, que els ajude a reflexionar sobre els fenòmens educatius que ocorren a l'aula escolar i els permeta enfrontar-s'hi des d'un plantejament que considera l'ensenyament-aprenentatge de les matemàtiques com una tasca interdisciplinària i globalitzadora, que parteix d'una concepció sociocultural de l'educació en general i de l'educació matemàtica en particular (Vygotsky, 1989; Bishop, 1999). Tanmateix, desenvoluparem el seu contingut prenent com a marc general de les característiques psicològiques dels xiquets i les xiquetes els quatre estadis del desenvolupament cognitiu de les persones que Jean Piaget (Piaget i Inhelder, 1984) estableix en els seus estudis.

Respecte a l'alumnat del Grau en Mestre/a d'Educació Infantil de la Universitat Jaume I, aquest document representa un material complementari per les classes presencials, en les quals s'aprofundeix en el text que relaciona la fonamentació matemàtica dels conceptes amb la seua didàctica, mitjançant la realització de diferents activitats que es desenvolupen al llarg del curs acadèmic.

Pressuposem que, a les aules d'infantil on es treballen els continguts d'aquest document, es troben els materials didàctics estructurats que descriurem més endavant o d'altres semblants ideats i fabricats pels docents i/o l'alumnat, que hauran de compartir en la seua essència allò que és fonamental per a la construcció dels continguts matemàtics que es desenvolupen en aquesta publicació. Els esmentats materials constitueixen un suport imprescindible per al treball a l'aula relatiu als conceptes estudiats.

El present document no esgota les activitats que els mestres i les mestres d'educació infantil han de realitzar a les aules. La gran varietat de possibles dispositius didàctics que poden oferir als xiquets i les xiquetes és impossible de reflectir en qualsevol publicació. El nostre interés és posar l'atenció en el que han de treballar per fonamentar matemàticament els procediments emprats per l'alumnat i donar indicacions de com han de fer-ho. Mai esgotarem la creativitat didàctica que un docent ha de tenir en la seua tasca diària. 


\section{TEMA 1}

\section{Desenvolupament dels conceptes lògics}

\section{Introducció}

Mitjançant la formació de conjunts i la classificació i ordenació d'elements, en aquest tema pretenem oferir als xiquets i les xiquetes les eines matemàtiques que els ajuden a respondre les preguntes que la realitat els planteja respecte a «com són els objectes?, en què s'assemblen?, en què es diferencien?, com es relacionen?».

Comença amb una aproximació al significat de la lògica en la història, continua amb la formalització d'alguns conceptes de la Teoria de Conjunts i finalitza amb un extens tractament didàctic de com treballar els conceptes lògics a l'aula d'infantil.

\subsection{Històrica}

Una primera definició de lògica podria enunciar-se com «la disciplina que tracta dels mètodes de raonament, és a dir, que ofereix regles i tècniques per tal de determinar si un argument és vàlid».

A grans trets, la història de la lògica es divideix en tres etapes: la lògica grega, la lògica escolàstica i la lògica matemàtica.

El primer estudi sistemàtic del raonament lògic es troba en l'obra d'Aristòtil (384$322 \mathrm{aC}$ ). La lògica aristotèlica enuncia les fórmules amb paraules del llenguatge quotidià.

Durant la segona etapa, la lògica es va abstraure del llenguatge i es caracteritzà per unes regles sintàctiques diferenciades $i$ unes funcions semàntiques especials.

En aquestes dues etapes els teoremes lògics es derivaven del llenguatge usual.

En la tercera etapa, la lògica queda marcada per l'ús d'un llenguatge artificial en el qual els signes $i$ les paraules es regeixen per una sintaxi exacta $i$ tenen una funció estretament delimitada i definida. En aquest cas, en primer lloc es construeix un sistema purament formal i sols més tard es busca una interpretació en el llenguatge quotidià. Leibniz (1646-1716) va ser el precursor d'aquesta manera d'usar la lògica. 
El naixement de la lògica contemporània se situa entre els anys 1847, quan De Morgan publica el seu llibre Formal Logic, i 1854 quan es publica el primer llibre de Boole que porta per títol Investigació sobre les lleis del pensament, en el qual es construeix i es desenvolupa la lògica formal com un nou tipus d'àlgebra que subministra un algorisme fàcil pel raonament sil·logístic. Després de la mort de Boole i fins a la publicació, entre 1910 i 1913, de Principia Mathematica de Russell i Whitehead, l'interés per la lògica va ser mínim. En aquesta darrera obra s'intenta posar de manifest que tota la matemàtica pura es pot deduir d'un petit nombre de principis lògics fonamentals (axiomes).

Kurt Gödel, en el seu teorema d'incompletesa, va demostrar al 1931 que això no és possible perquè en un sistema formulat de manera estrictament lògica hi ha sempre proposicions indecidibles a partir dels axiomes del sistema. Estableix, a més a més, que l'aritmètica bàsica no pot demostrar la seua pròpia consistència i, per tant, és impossible demostrar-la respecte de qualsevol sistema matemàtic més complex. Aquest teorema està considerat com el resultat més important de la lògica matemàtica.

\subsection{Al tema}

Com s'ha esmentat en el punt anterior, la lògica es pot considerar com la disciplina filosòfica que estudia les formes o estructures del pensament. També és l'àrea de la filosofia que estudia els raonaments i les condicions segons els quals aquests seran correctes i veritables.

S'entén per raonament l'operació mental mitjançant la qual s'obté la comprensió teòrica de la realitat, la formació de conceptes i la indagació sobre la seua naturalesa.

Amb aquestes definicions inicials ja es pot intuir que la introducció, el desenvolupament i l'estudi de conceptes lògics estan justificats dins de l'aula d'infantil, perquè pensar és determinar relacions entre conceptes i quan raonem ja estem formant judicis entre dos o més.

Si es poguera establir un ordre d'accés al pensament, una primera operació mental lògica seria l'anomenada aprehensió, que consisteix a enfrontar-se a un objecte determinat per a obtenir com a resultat l'elaboració d'un concepte o una idea. Una segona operació mental lògica és el judici, en el qual la intel·ligència aferma o rebutja l'existència d'una relació entre dues naturaleses, essències o conceptes. Com a tercera operació mental lògica hi hauria el raciocini, on s'agrupen, es lliguen i es vinculen els conceptes per la raó segons unes regles o lleis determinades.

La lògica està present en qualsevol nivell de pensament existent, des del més quotidià fins al més elevat de l'ésser humà, un exemple del qual podria ser el mètode científic. 


\section{Formalització dels conceptes de la teoria de conjunts}

La Teoria de Conjunts és l'encarregada de simbolitzar el llenguatge matemàtic. És per això que formant conjunts expressem els conceptes que componen el currículum escolar i afavorim el seu aprenentatge.

Presentem, a continuació, una breu formalització d'alguns conceptes de la Teoria de Conjunts, necessaris per treballar els continguts d'aquest tema i també dels posteriors de la present publicació.

\subsection{Introducció}

El concepte de conjunt és intuïtiu i no es pot definir amb rigor. Es podria entendre com «una agrupació d'elements feta amb qualsevol criteri». El criteri pot no ser una propietat característica comú, sinó simplement el desig o la necessitat d'agrupar certs objectes o elements per a formar un conjunt. Així, podem parlar d'un conjunt de persones, de fruites, de contes, o del conjunt d'objectes que hi ha en un moment determinat dins d'un calaix. Un conjunt està ben determinat si se sap si un element donat pertany o no al conjunt; així, el conjunt dels bolígrafs blaus està ben determinat, perquè en veure un bolígraf podem saber si és blau o no. El conjunt de les persones altes no està ben determinat fins que no quede establert $o$ definit de forma unívoca què és ser alt, perquè en veure una persona, no sempre es podrà dir si és alta o no, o poden haver-hi diferents persones que opinen distint sobre la seua altura.

Els conjunts es representen, normalment, amb una lletra majúscula: $\boldsymbol{A}, \boldsymbol{B}, \boldsymbol{K} \ldots$

Anomenarem element a cadascun dels objectes que formen part d'un conjunt. Aquests elements tenen caràcter individual, tenen qualitats que ens permeten diferenciar-los i cadascun és únic, de manera que no hi ha elements duplicats o repetits. Els representarem amb una lletra minúscula: $\boldsymbol{a}, \boldsymbol{b}, \boldsymbol{k} \ldots$ Quan un element $\boldsymbol{a}$ forma part d'un conjunt $\boldsymbol{A}$, direm que pertany a eixe conjunt i ho expressarem com $a \in A$.

Es defineix cardinal d'un conjunt com «la quantitat d'elements que hi ha en el conjunt».

S'anomena conjunt universal o referencial, que habitualment representarem amb la lletra $\boldsymbol{U}$, el conjunt de tots els elements dels quals s'estiga tractant en una determinada situació; així, si parlem de mamífers, $\boldsymbol{U}$ és el conjunt de tots els animals mamífers; si parlem de ciutats, $\boldsymbol{U}$ és el conjunt de totes les ciutats. Aquest conjunt universal o referencial pot esmentar-se explícitament o, en la majoria dels casos, es dóna per conegut atès el context que s'estiga tractant. 
Sempre ha estat molt utilitzada la idea de conjunt al llarg de la història, en qualsevol representació o explicació matemàtica, però no serà fins al segle xIX quan se li atorgarà rigor.

En aquest segle, Cantor posa les bases per a la construcció de la Teoria de Conjunts: definicions, introducció a cardinals, conjunt ben ordenat... Inicialment es plantejaren alguns problemes lògics relacionats amb aquesta teoria, que es van resoldre mitjançant l'elaboració de sistemes axiomàtics (són conjunts d'afirmacions admeses com a vertaderes sense necessitat de demostració) com els de ZermeloFrenkel, els de Newman..., que la fonamenten adequadament.

\subsection{Conjunts}

En aquest apartat es fa un recorregut per alguns conceptes (operacions, relacions...) de la Teoria de Conjunts que resulten fonamentals perquè els xiquets i les xiquetes d'educació infantil puguen construir els seus coneixements matemàtics.

\subsubsection{Definicions i conceptes bàsics}

Com s'ha esmentat al punt anterior, s'admet la idea de conjunt com l'agrupació en un tot de determinats objectes (no necessàriament físics) ben definits i diferenciats els uns dels altres. A partir d'aquesta idea, introduirem a continuació els següents conceptes essencials:

- Determinacions d'un conjunt:

- Per comprensió: explicitant la propietat característica dels seus elements. Per exemple, el conjunt de vocals de l'alfabet espanyol: $V=\{$ vocals de l'alfabet espanyols.

- Per extensió: enumerant, un per un, tots els elements que el componen. Per exemple, el conjunt format per les lletres a, e, i, o, u: $V=\{a, e, i, o, u\}$.

- Representacions d'un conjunt:

- Representació gràfica: diagrama lineal, diagrama de Venn (línia corba tancada que delimita els elements del conjunt) o un altre diagrama format per qualsevol línia tancada.
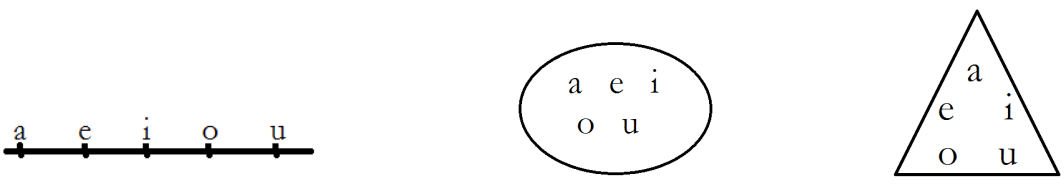

Figura 1. Representació de conjunts: diagrama lineal (esquerra), de Venn (centre)

i un altre de línia tancada (dreta) 
- Representació simbòlica: com s'ha esmentat abans, s'utilitzaran lletres en minúscula per tal de representar els elements d'un conjunt $i$ en majúscula per a representar els conjunts.

- Conjunts iguals: aquells que tenen els mateixos elements. Per exemple, el conjunt format per les vocals de la paraula «meravellosa» i el que té com a elements les vocals de «coseta»: $M=\{e, a, o\}=\{o, e, a\}=C$.

- Subconjunts: un conjunt A és subconjunt d'un altre X si i sols si qualsevol element de A és també element de X, la qual cosa s'expressa formalment per: $A \subset X \leftrightarrow[\forall a \in A \rightarrow a \in X]$. Per exemple, si X és el conjunt de tots els mamífers i A és el dels felins, és clar que A és un subconjunt de $X$, per tant tots els felins són mamífers.

- Conjunt universal o referencial: com ja s'ha esmentat abans, és el conjunt de tots els elements dels quals s'estiga tractant en un determinat moment o situació i s'anomena per la lletra $\mathbf{U}$.

- Conjunt complementari d'un subconjunt: siga A un subconjunt de X. Definim complementari de A respecte a $X$ com el conjunt dels elements de $\mathrm{X}$ que no pertanyen a A. Formalment: $A \subset X: A_{X}^{c}=\{x \in X / x \notin A\}$. Per exemple, si $\mathrm{X}$ és el conjunt de mobles d'una casa i A és el de les cadires, el complementari de A respecte a X és el conjunt dels mobles que no són cadires (taules, llits, consoles, armaris...).

- CONJUNT BUIT: $\Phi$, aquell que no té cap element.

\subsubsection{Operacions entre conjunts}

- Unió: siguen A i B dos conjunts. El conjunt unió de A i B està format per tots els elements que pertanyen a $\mathbf{A}$ o a $\mathrm{B}$. La representació formal és: $A \cup B=\{x / x \in A \vee x \in B\}$. Per exemple, si A és un conjunt de boletes de fusta per a fer un collar i $\mathrm{B}$ és un de boletes roges, $A \cup B$ serà el conjunt de boletes que siguen de fusta o roges, com es veu en la figura 2 .

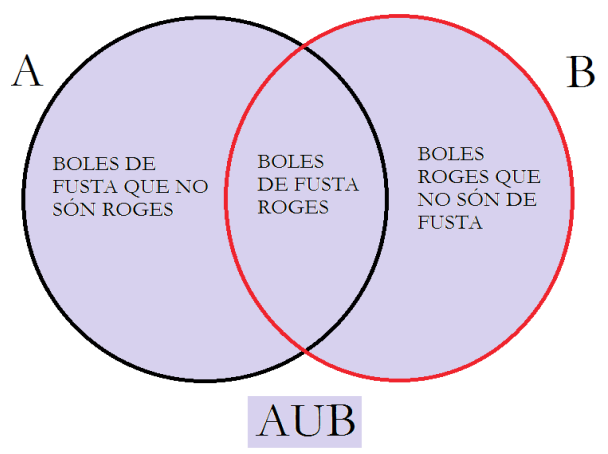

Figura 2. Representació de la unió dels conjunts A i B 
Si els conjunts no tenen elements en comú, per exemple, $C$ és un conjunt de boletes de color blau i B segueix sent un de boles roges, $C \cup B$ serà el conjunt de boletes que siguen blaves o roges. La representació gràfica serà ara la que apareix en la figura 3.

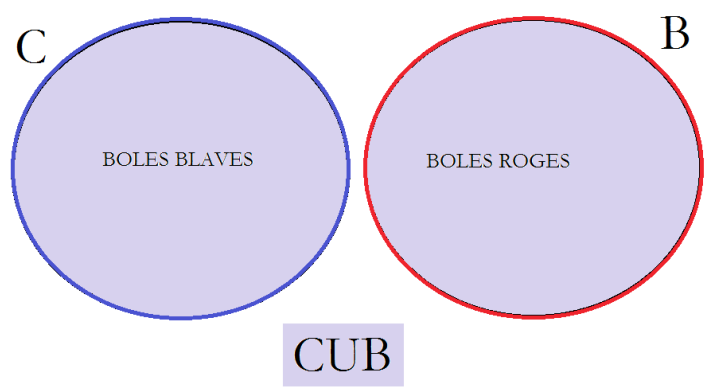

Figura 3. Representació de la unió dels conjunts C i B

- Intersecció: siguen A i B dos conjunts. El conjunt intersecció de A i B està format per tots els elements que pertanyen a $\mathbf{A}$ i a $\mathbf{B}$. Expressat formalment: $A \cap B=\{x / x \in A \wedge x \in B\}$. Per exemple, si $\mathbf{A}$ i $\mathbf{B}$ son els conjunts dels exemples anteriors, $A \cap B$ serà el conjunt de boletes que siguen de fusta i de color roig. La representació es pot observar en la figura 4.

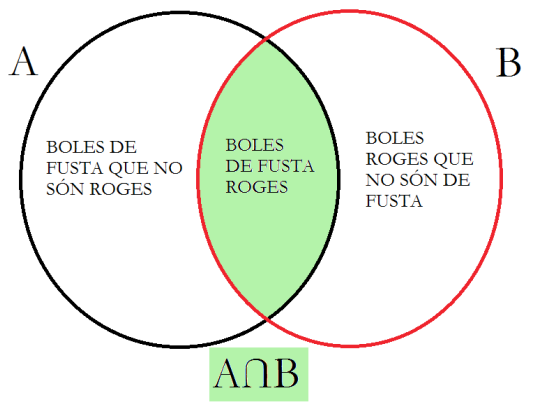

Figura 4. Representació de la intersecció dels conjunts A i B

Si els conjunts no tenen elements en comú, la seua intersecció és el conjunt buit i s'anomenen conjunts disjunts. Per exemple, si volem obtenir la intersecció dels conjunts $\mathrm{C}$ i B anteriors, observem que $C \cap B=\Phi$ i per tant no es podria acolorir cap zona comú en la representació gràfica.

Algunes propietats de la unió i de la intersecció:

1. Commutativa: $A \bigcup B=B \bigcup A$ i $A \cap B=B \cap A$

2. Associativa: $A \bigcup(B \bigcup C)=(A \bigcup B) \bigcup C i A \cap(B \cap C)=(A \cap B) \cap C$

3. Distributiva:

$A \bigcup(B \cap C)=(A \cup B) \cap(A \cup C) i A \cap(B \bigcup C)=(A \cap B) \bigcup(A \cap C)$

4. $A \bigcup A^{c}=U$ i $A \bigcup \Phi=\mathrm{A}$

7. $A \cap A^{c}=\Phi$ i $A \cap \Phi=\Phi$ 
- Partició d'un conjunt: siga $\mathbf{A}$ un conjunt i $\mathbf{A}_{1}, \mathbf{A}_{2}, \ldots, \mathbf{A}_{\mathbf{n}}$ subconjunts de A. Direm que $\left\{A_{1}, A_{2}, \ldots, A_{n}\right\}$ és una partició de $\mathrm{A}$, si i només si (en endavant sii):

- Tots els $\mathbf{A}_{\mathrm{i}}$ són subconjunts no buits de $\mathrm{A}: A_{i} \neq \Phi, \forall i=1, \ldots, n$

- La unió de tots els subconjunts $\mathbf{A}_{\mathbf{i}}$ és el conjunt $\mathbf{A}: \bigcup_{i=1}^{n} A_{i}=A$

- Els subconjunts $\mathbf{A}_{\mathbf{i}}$ són disjunts dos a dos: $A_{i} \cap A_{j}=\Phi, \forall i \neq j$

Per posar un exemple, utilitzarem els blocs lògics de Dienes (figura 5) compostos per 48 peces de fusta o plàstic organitzades al voltant de quatre característiques (color, forma, grandària $\mathrm{i}$ grossària) que es distribueixen en funció de tres valors pel color (roig, groc i blau), quatre per la forma (cercle, triangle, quadrat i rectangle), dos per la grandària (gran i menut) i dos per la grossària (gros i prim) (Kothe, 1982; Santos, 1992).

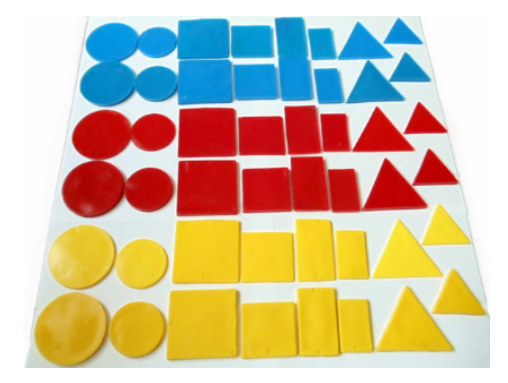

Figura 5. Imatge dels blocs lògics de Dienes

Així, si A és el conjunt de les 48 peces dels blocs lògics de Dienes i considerem com a $\mathbf{A}_{1}$ el de les peces grans i com a $\mathbf{A}_{2}$ el de les petites, es pot comprovar fàcilment que $\left\{A_{1}, A_{2}\right\}$ és una partició de $\mathrm{A}$. Mentre que si $\mathbf{A}_{1}$ són les peces roges, $\mathbf{A}_{2}$ les circulars i $\mathbf{B}_{3}$ les grosses, $\left\{B_{1}, B_{2}, B_{3}\right\}$ no és una partició de $\mathrm{A}$ perquè no s'acompleixen la segona i tercera condicions.

- Producte cartesià: es defineix el producte cartesià dels conjunts A i B com el conjunt format pels parells ordenats que tenen com a primer component un element de A i com a segon un de $\mathbf{B}: A x B=\{(a, b) / a \in A \wedge b \in B\}$.

Per exemple, si $\mathbf{A}=$ \{paella, sopa, macarrons $\}$ és el conjunt de primers plats d'un menú i $\mathbf{B}=\{\mathbf{c a r n}, \mathbf{p e i x}\}$ és el de segons plats, el producte cartesià serà el conjunt de totes les possibles combinacions que es poden obtenir seleccionant un primer i un segon plat, és a dir, $\mathbf{A} \times \mathbf{B}=\{$ (paella, carn), (sopa, carn), (macarrons, carn), (paella, peix), (sopa, peix), (macarrons, peix)\} .

Algunes propietats del producte cartesià:

1. $\operatorname{card}(A \times B)=\operatorname{card}(A) \cdot \operatorname{card}(B)$

2. $A \times B \neq B \times A$

3. $A \times(B \cup C)=(A \times B) \cup(A \times C)$ 


\subsection{Correspondències}

Una correspondència, $\mathbf{f}$, entre dos conjunts $\mathbf{A}$ i $\mathbf{B}$ és qualsevol criteri que ens permet associar elements de A amb elements de B. A s'anomena conjunt inicial i B conjunt final.

Els elements de A als quals els correspon algun element de $\mathbf{B}$ són els elements origen i els de $\mathbf{B}$ que s'associen amb algun de A són els elements imatge.

Formalment, una correspondència $\mathbf{f}$ és una terna $(A, B, G(f))$, on:

- A, B són conjunts i $f: A \rightarrow B$ associa elements de A amb elements de $\mathbf{B}$. Quan dos elements, $x \in A$ i $y \in B$, estan associats mitjançant aquesta correspondència, ho expressem per $f(x)=y$.

- $D(f)=\{x \in A / \exists y \in B: f(x)=y\}$ és el conjunt domini de la correspondència $\mathrm{i}$ està format pels elements origen.

- $\operatorname{Im}(f)=\{y \in B / \exists x \in A: f(x)=y\}$ és el conjunt imatge de la correspondència i està format pels elements imatge.

- $G(f) \subset A x B$, s'anomena graf de la correspondència i està format pels parells $(\mathbf{x}, \mathbf{y})$ on $\mathbf{x}$ és un element origen i $\mathbf{y}$ és la seua corresponent imatge: $G(f)=\{(x, y) \in A \times B / x \in D(f), y \in \operatorname{Im}(f) \wedge y=f(x)\}$.

Qualsevol correspondència ens permet definir la seua correspondència recíproca o inversa, de la següent manera: $f^{-1}: B \rightarrow A / D\left(f^{-1}\right)=\operatorname{Im}(f) i \operatorname{Im}\left(f^{-1}\right)=D(f)$. És a dir, la correspondència inversa associa els elements de $\mathbf{B}$ amb els seus corresponents en $\mathbf{A}$ i converteix els elements origen en imatges i viceversa. Així, si $x \in A, y \in B$ i $f(x)=y \Rightarrow f^{-1}(y)=x$.

Algunes correspondències poden ser:

- Unívoca: a cada element de A li correspon un element o cap de B. Per exemple, si $\mathbf{A}=\{$ Elena, Irene, Ángela, Adela $\}$ i $\mathbf{B}=\{\mathbf{b}, \mathbf{i}, \mathbf{r}, \mathbf{l}, \mathbf{a}\}$, establim entre ells la correspondència que associa cada nom de $\mathrm{A}$ amb la seua lletra inicial en B. Com es pot comprovar en la figura 6 , aquesta correspondència és unívoca.

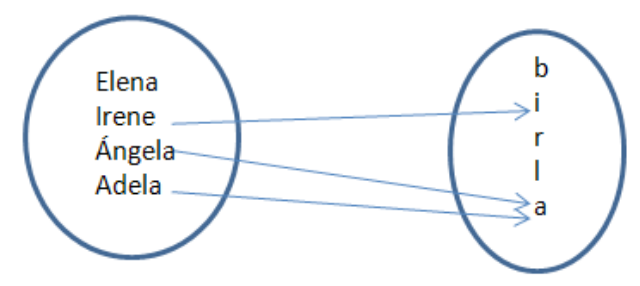

Figura 6. Representació d'una correspondència unívoca

- Biunívoca: tant $\mathbf{f}$, com $\mathbf{f}^{-1}$, són unívoques. És a dir, a cada element de A li correspon un o cap de $\mathbf{B}$ i a cada element de $\mathbf{B}$ li correspon un o cap de A. Si 
ara $\mathbf{A}=\{$ Elena, Irene, Ángela, Jorge $\}, \mathbf{B}=\{\mathbf{b}, \mathbf{i}, \mathbf{r}, \mathbf{l}, \mathbf{a}\}$ i associem elements amb el mateix criteri anterior, podem veure en la figura 7 que la correspondència és biunívoca.

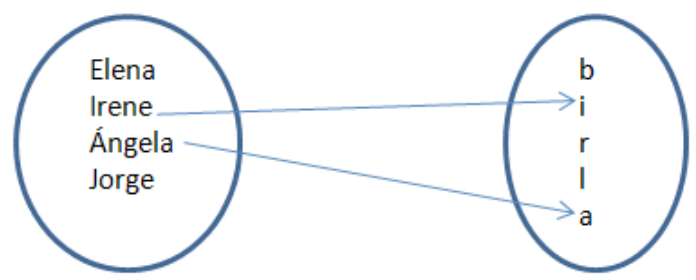

Figura 7. Representació d'una correspondència biunívoca

- Aplicació: tot element de A té imatge en $\mathbf{B}$ i aquesta és única. És a dir, $\forall a \in A, \exists ! b \in B / f(a)=b$. Veiem en aquest cas un exemple amb $\mathbf{A}=\{$ Elena, Irene, Ángela, Adela $\}$ i $\mathbf{B}=\{\mathbf{a}, \mathbf{e}, \mathbf{i}, \mathbf{0}, \mathbf{u}\}$. Si associem elements d'ambdós conjunts amb el mateix criteri de les correspondències anteriors, en la figura 8 observem que hem definit una aplicació.

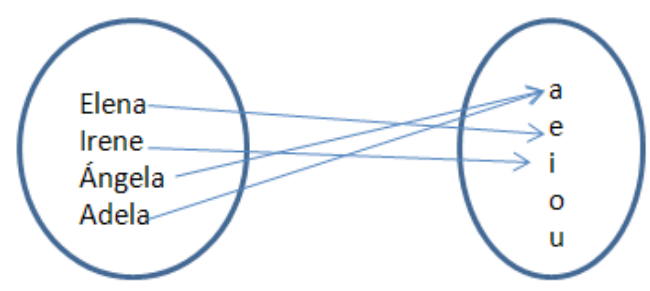

Figura 8. Representació d'una aplicació

- Bijectiva: tot element de A té una única imatge en $\mathbf{B}$ i tot element de $\mathbf{B}$ té un únic origen en $\mathbf{A}$, o dit d'una altra manera, tant $\mathbf{f}$ com $\mathbf{f}^{-1}$ són aplicacions. En aquest cas mostrem l'exemple amb $\mathbf{A}=$ \{Elena, Irene, Ángela, Úrsula, Odet $\}$ i $\mathbf{B}=\{\mathbf{a}, \mathbf{e}, \mathbf{i}, \mathbf{o}, \mathbf{u}\}$. Si associem elements amb el criteri anterior, en la figura 9 podem observar una aplicació bijectiva.

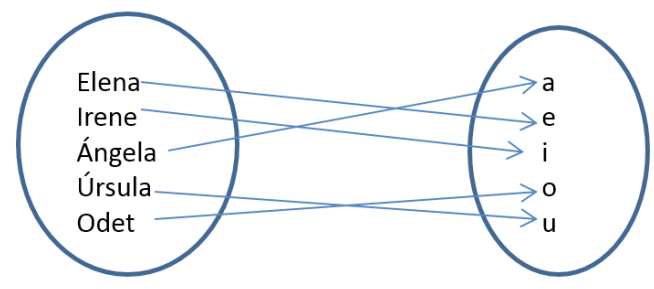

Figura 9. Representació d'una aplicació bijectiva

- Composició d'aplicacions: donada una aplicació $f: A \rightarrow B$, i una altra $g: B \rightarrow C$ de forma que $\forall a \in A \quad f(a)=b \wedge \forall b \in B \quad g(b)=c$, es defineix la composició d'aplicacions com una altra aplicació $g \circ f: A \rightarrow C$, acomplint que $\forall a \in A \quad g \circ f(a)=g(f(a))=g(b)=c$. Si les aplicacions $f$ i $g$ són bijectives, la seua composició $g \circ f$ també ho és. 


\subsection{Relacions binàries}

Una relació binària és una associació o connexió que s'estableix entre parelles d'elements d'un conjunt. Poden haver-n'hi moltes definides en un mateix conjunt. Analíticament, podem dir que la relació $\mathbf{R}$ és una terna $(\mathbf{A}, \mathbf{A}, \mathbf{G}(\mathbf{R}))$, on $G(R) \subset A \times A$, com ocorre al punt anterior, aleshores direm que $\mathbf{x} \mathbf{R y}$ sii $(\mathbf{x}, \mathbf{y})$ pertany a $\mathbf{G}(\mathbf{R})$.

Les propietats que poden complir les relacions binàries són $\forall x, y, z \in A$ :

1. Reflexiva: xRx. Tot element està relacionat amb si mateix. Per exemple, la relació «practicar el mateix esport» definida en un conjunt de persones acompleix la propietat reflexiva.

2. Antireflexiva: $x \bar{R} x$. Qualsevol element no es relaciona amb si mateix. Per exemple, «ser pare de» és una relació antireflexiva.

3. Simètrica: $\mathbf{x} \mathbf{R y} \rightarrow \mathbf{y R x}$. Si un element es relaciona amb un altre, aleshores el segon es relaciona amb el primer. Per exemple, la relació «practicar el mateix esport» acompleix la propietat simètrica.

4. Antisimètrica: $\mathbf{x} \mathbf{R y} \wedge \mathbf{y} \mathbf{R x} \rightarrow \mathbf{x}=\mathbf{y}$ o bé, $\mathbf{x} \neq \mathbf{y} \wedge \mathbf{x} \mathbf{R y} \rightarrow y \bar{R} x$. Si un element està relacionat amb un altre $i$ aquest ho està amb el primer, necessàriament han de ser el mateix element (si partim de dos element diferents i el primer es relaciona amb el segon, aleshores el segon no està relacionat amb el primer). Per exemple, «tenir més edat que» és una relació antisimètrica.

5. Transitiva: $\mathbf{x R y} \wedge \mathbf{y R z} \rightarrow \mathbf{x R z}$. Si un primer element està relacionat amb un segon, i alhora aquest es relaciona amb un tercer, aleshores el primer ho està també amb el tercer. Per exemple, la relació «ser de la mateixa edat» acompleix la propietat transitiva.

6. Connexa: $\mathbf{x R y} \wedge \mathbf{y R x}$. Si agafem dos elements qualssevol s'acompleix que el primer està relacionat $\mathrm{amb}$ el segon o viceversa. Per exemple, la relació «ser menor o igual» definida en el conjunt dels nombres naturals és connexa.

Una relació binària definida en un conjunt és relació binària d'equivalència (RBE) si compleix les propietats reflexiva, simètrica i transitiva. En el conjunt en el qual està definida aquesta relació es produeix una classificació dels seus elements, que s'organitzen en subconjunts, anomenats classes d'equivalència, formats pels elements que estan relacionats entre si, és a dir, que són equivalents respecte d'aquesta relació. El conjunt els elements del qual són les classes d'equivalència s'anomena conjunt quocient.

Per exemple, en el conjunt $\mathbf{A}=$ \{estudiants del Grau en Mestre/a de l'UJI $\}$ definim la relació binaria $a R b \leftrightarrow a i b$ van nàixer en la mateixa població. Anem a comprovar si és d'equivalència: 
- Reflexiva: qualsevol element de $\mathrm{A}$ està relacionat amb si mateix, puix que cada estudiant ha nascut en el mateix poble que ell/a (aRa).

- Simètrica: si un estudiant va nàixer en la mateixa població que un altre, el segon també va nàixer en el mateix poble que el primer $(\mathbf{a R b} \rightarrow \mathbf{b R a})$.

- Transitiva: si un estudiant va nàixer en la mateixa població que un altre $\mathrm{i}$ aquest en la mateixa que un tercer, el primer va nàixer en el mateix poble que el tercer $(\mathbf{a R b} \wedge \mathbf{b} \mathbf{R c} \rightarrow \mathbf{a R c})$.

Per acomplir aquestes tres propietats, la relació «nàixer en la mateixa població» és una relació binària d'equivalència, que agrupa els estudiants en classes d'equivalència formades pels estudiants del mateix poble, com per exemple, $\mathbf{A}_{1}=\{$ estudiants de Mestre/a de l'UJI nascuts a Castelló $\}, \mathbf{A}_{2}=\{$ estudiants de Mestre/a de l'UJI nascuts a Vila-real $\}, \mathbf{A}_{3}=\{$ estudiants de Mestre/a de l'us nascuts a Benicàssim $\} \ldots$ Aquestes classes, que són subconjunts de A, generen una partició d'aquest conjunt i són els elements del conjunt quocient $\mathbf{A} / \mathbf{R}$ :

$\mathbf{A} / \mathbf{R}=\left\{\mathbf{A}_{1}, \mathbf{A}_{2}, \mathbf{A}_{3}, \ldots\right\}=\{\{$ estudiants de Mestre/a de l'UsI nascuts a Castelló $\},\{$ estudiants de Mestre/a de l'UII nascuts a Vila-real\}, \{estudiants de Mestre/a de l'UJI nascuts a Benicàssim $\}, \ldots\}$

Una relació binària definida en un conjunt és relació binària d'ordre (RBO) si compleix les propietats reflexiva, antisimètrica i transitiva (també s'anomena $d$ 'ordre ampli). Per exemple, en el conjunt $\mathbf{A}=$ \{estudiants del Grau en Mestre/a de l'UsI triats de manera que no hi ha dues persones amb la mateixa edat\} definim la relació binaria $a R b \leftrightarrow a$ té menor o igual edat que b. Anem a comprovar si és d'ordre:

- Reflexiva: qualsevol element de A està relacionat amb si mateix, puix que cada estudiant té la mateixa edat que ell/a (aRa).

- Antisimètrica: si considerem dos estudiants diferents i el primer té menor o igual edat que el segon, és clar que el segon no pot tenir menor o igual edat que el primer (tenint en compte que en A no hi ha dos estudiants amb la mateixa edat) $(\mathbf{a} \neq \mathbf{b} \wedge \mathbf{a} \mathbf{R} \mathbf{b} \rightarrow b \bar{R} a)$.

- Transitiva: si un estudiant té menor o igual edat que un altre i aquest menor o igual que un tercer, el primer té menor o igual edat que el tercer $(\mathbf{a R b} \wedge$ bRc $\rightarrow$ aRc).

Per acomplir aquestes tres propietats, la relació «tenir menor o igual edat que» és una relació binària d'ordre (ampli) en el conjunt $\mathrm{A}$.

Si s'acomplira l'antireflexiva a més de l'antisimètrica i la transitiva, tindríem una relació binària d'ordre estricte (per exemple, «tenir menor edat que» en un conjunt de persones qualssevol). Si una relació binaria sols acompleix les propietats reflexiva i transitiva s'anomena de preordre («ser múltiple de» en el conjunt 
dels nombres enters). Qualsevol relació d'ordre definida anteriorment s'anomena d'ordre parcial, perquè no se li ha exigit que acomplisca la propietat connexa. Si aquesta propietat s'acompleix, les relacions s'anomenen d'ordre total.

\section{Els conceptes lògics a l'aula d'infantil}

\subsection{Consideracions prèvies}

Per ajudar-los a entendre la realitat que els envolta, els xiquets i les xiquetes d'educació infantil han d'anar coneixent les característiques o qualitats dels objectes, així com els seus valors (per exemple, la qualitat color pot prendre els valors roig, verd, groc...), per tal de poder formar conjunts i establir relacions entre ells. És a dir, hauran d'avançar des del coneixement físic dels objectes fins a un coneixement lògico-matemàtic, dels mateixos, que els permeta agrupar-los i relacionar-los en funció de les seues semblances o diferències.

\subsection{Capacitats per desenvolupar a l'aula d'infantil}

L'objectiu del tema serà establir els primers passos d'aquest pensament lògic d'una manera seqüencial i adequada a l'educació infantil, que contribuirà a desenvolupar en l'alumnat les següents capacitats:

1. Captar les qualitats dels objectes a partir del contacte directe amb ells.

1.1. Manipular i diferenciar materials separats i continus.

1.2. Distingir característiques sensorials mitjançant la vista.

1.3. Distingir característiques sensorials mitjançant el tacte.

1.4. Distingir característiques sensorials mitjançant l'olfacte.

1.5. Distingir característiques sensorials mitjançant el gust.

1.6. Distingir característiques sensorials mitjançant l'oïda.

2. Descriure diverses característiques que té un objecte.

3. Descriure diverses característiques que no té un objecte.

4. Reconèixer característiques d'objectes representats en imatges.

5. Identificar objectes determinats per diverses de les seues característiques.

6. Identificar diversos elements que tenen una mateixa característica.

7. Formar conjunts segons característiques sensorials dels objectes.

7.1 Formar conjunts determinats per una característica enunciada de manera afirmativa.

7.2 Formar conjunts determinats per una característica enunciada de forma negativa.

7.3 Formar conjunts determinats per una característica i observar el conjunt que determina la seua negació.

7.4 Formar conjunts determinats per més d'una característica comuna.

8. Enumerar els elements que formen part d'un conjunt i reconèixer alguns que no en formen part. 
9. Identificar la propietat característica que determina un conjunt.

10. Formar conjunts a partir d'elements representats en imatges.

11. Representar gràficament els conjunts formats.

12. Trobar diferències entre els elements d'un conjunt determinat per una característica i formar subconjunts a partir d'elles.

13. Classificar elements per semblances qualitatives.

14. Completar sèries d'elements en les quals vagen canviant les característiques del material segons un criteri donat.

15. Ordenar elements segons els matisos d'una de les seues qualitats.

16. Establir correspondències qualitatives entre els elements de dos conjunts.

17. Representar gràficament relacions i associacions d'elements.

\subsection{Desenvolupament de les capacitats}

En aquest apartat es recorren per ordre creixent de dificultat els procediments per a la construcció dels conceptes que es treballen en el tema, des del primer contacte que els xiquets i les xiquetes hi tenen a l'aula, fins al seu grau d'adquisició, cosa que es pot aconseguir en finalitzar aquesta etapa. La major part del treball d'aquestes capacitats es desenvoluparà al llarg del 2n cicle d'educació infantil (3-6 anys), encara que algunes qüestions molt senzilles es poden tractar al final del 1r cicle (0-3 anys).

En general, treballarem a partir de situacions reals que es plantegen i es desenvolupen a l'aula i a l'entorn, i haurem d'aprofitar les experiències anteriors de l'alumnat per tal de agafar-les com a punt de partida per a la construcció dels conceptes lògico-matemàtics corresponents a aquesta etapa.

Els materials didàctics específics són una ajuda que sempre cal tenir a l'aula d'infantil com a complement de les situacions abans esmentades. No només perquè és una edat en la qual han de manipular, també perquè el seu ús possibilita la creació de referents gràfics i imatges mentals als quals recórrer quan s'intenta fer qualsevol pas cap a l'abstracció.

Cal invertir temps per conèixer les possibilitats que un material ofereix, pensar activitats per a desenvolupar les potencialitats dels xiquets i les xiquetes d'educació infantil i, evidentment, treballar les capacitats que s'estudien a continuació.

En particular, volem prestar especial atenció als blocs lògics de Dienes que s'han descrit en l'apartat 2.2.2, i als que farem freqüent referència al llarg d'aquest tema, per considerar-los un material estructurat que integra moltes característiques dels objectes i que permet realitzar una gran varietat d'activitats relacionades amb el desenvolupament del pensament lògico-matemàtic al qual es refereixen les capacitats del present tema.

Iniciarem el treball amb aquest material al principi del segon cicle llevant les peces rectangulars i eliminant totes les primes. Cap la meitat del cicle incorporarem els 
rectangles grossos i, una vegada haja avançat un poc més el segon curs, es treballarà també la grossària, utilitzant les peces primes i les grosses. Amb aquest material es pretén assolir, entre d'altres, els següents dos objectius:

1. Reconèixer i diferenciar colors, formes, grandàries i grossàries.

2. Formar conjunts i classificar en funció de les característiques esmentades.

Podem trobar comercialitzats altres materials estructurats de característiques semblants als blocs lògics de Dienes, l'essència dels quals coincideix amb aquests, permetent-nos treballar objectius semblants i col·laborant també a la construcció del coneixement matemàtic de l'alumnat.

S'aconseguirà dotar un aula d'educació infantil amb el material didàctic necessari, bé comprant-lo en tendes especialitzades, bé construint-lo el mateix docent amb ajuda de l'alumnat i/o dels familiars.

\section{Captar les qualitats dels objectes a partir del contacte directe amb ells}

El desenvolupament d'aquest procés ha d'estar lligat irremeiablement al fet habitual de manipular els objectes de la realitat i de rebre la major quantitat d'informació possible a través de la percepció pels sentits. Seran el tacte i la vista els primers sentits que discriminaran les característiques dels objectes, que es completaran amb les que es poden conèixer gràcies a les dades obtingudes amb els altres tres.

L'extensió d'aquest treball aconsella fraccionar-lo en apartats diferenciats per a cadascun dels sentits, a més de dedicar-ne un a la diferenciació inicial entre els dos tipus de materials que poden trobar en la realitat: separats i continus.

\subsection{Manipular i diferenciar materials separats $i$ continus}

El treball en aquesta capacitat serà diferent en funció dels materials que hi haja al davant. Haurem de distingir, doncs, entre materials separats i continus.

Els primers serien «tots aquells que estiguen compostos per unitats singulars», és a dir, unitats clarament diferenciables les unes de les altres, mentre que els segons «no estan compostos per aquest tipus d'unitats». Exemples del primer tipus podrien ser les taronges d'un fruiter, els llapis de color d'un estoig, els xiquets i les xiquetes de l'aula... Exemples clarificadors del segons tipus són un líquid qualsevol, una corda, un tros de tela...

En educació infantil s'intentarà que, a través de la manipulació, els nens i les nenes vagen experimentant, comparant i descobrint materials que es poden manipular un a un (els separats: pilotes, pedres, joguets, boletes...) i d'altres que no (els continus: sorra, aigua, corda, farina...). I tot això es farà mitjançant activitats de posar 
i treure, omplir i buidar, transportar, enfilar..., en definitiva, activitats quotidianes que els infants poden fer també fora de l'aula. En qualsevol dels casos s'adaptaran els materials a les possibilitats manipulatives i motrius pròpies de cada edat.

El coneixement de les diferències entre aquests dos tipus de materials, prepara el camí cap a la construcció del concepte de quantitat. Així, si es tracta de quantificar els materials separats caldrà realitzar activitats de comptatge amb els nombres naturals, i si es tracta de quantificar els materials continus es desenvoluparan activitats de mesura. Aquestes darreres són més complexes per a l'alumnat que les de comptatge, perquè el seu resultat és relatiu i depén de la unitat seleccionada per a mesurar.

En el treball referent a la quantificació dels materials, de vegades alguns dels separats presenten dificultats pel seu comptatge i es quantifiquen mesurant-los. Els anomenarem àrids, i alguns exemples són els macarrons, l'arròs, les lentilles... Malgrat què aquests materials no solen comptabilitzar-se, els xiquets i xiquetes poden utilitzar-los com a separats en la realització d'algunes activitats (un collar de macarrons, un dibuix emplenat de llentilles enganxades, etc.).

\subsection{Distingir característiques sensorials mitjançant la vista}

En aquest apartat es treballaran les següents qualitats dels objectes: grandària, color, forma, longitud i grossària.

A. Grandària dels objectes. Cap al final del 1r cicle cal treballar les diferències entre gran i menut, utilitzant objectes de grandària molt contrastada i que siguen el més semblant possible respecte de les altres característiques que els defineixen (dels mateixos colors, material...), per evitar que siguen aquestes les que centren l'atenció de l'alumnat (una pilota de ping-pong i una de bàsquet en un projecte sobre esports, dues prestatgeries en una activitat d'organització de l'aula, dos llibres de la biblioteca d'aula...).

Ja en el 2n cicle, per exemple en la comparació d'entrepans o llibres de contes, apareixerà un objecte més gran que el menut i més xicotet que el gran i que tinga una grandària intermèdia entre les dues anteriors. La confusió que crea la presència d'aquest objecte fa necessària la recerca d'un nom nou que reflectisca aquesta situació. És el moment d'introduir la idea de mitjà com la grandària que es troba entre gran i menut.

Mitjançant un procediment anàleg i un poc més avançat el cicle, augmentarem els diferents valors de les grandàries dels objectes que es treballen i caldrà introduir en el llenguatge quotidià paraules que matisen allò que volem dir respecte d'aquesta qualitat, per tal de concretar-la i fer la comunicació el més exacta possible, per exemple, molt gran, molt menut, gegant, nan...

A mesura que es van adquirint aquests coneixements, es poden comparar les grandàries d'objectes que no siguen tant semblants en la resta de caracterís- 
tiques, per a aconseguir la generalització dels conceptes. Així, per exemple, observaran i contrastaran les diferents grandàries d'una bala de vidre (cani$c a$ ), del got d'un iogurt, d'una caixa de sabates i d'un armari de l'aula.

B. Color dels objectes. Per treballar els colors, en un principi, caldrà prestar atenció individualment a cadascun d'ells, procurant que a l'aula hi haja més presència d'objectes d'eixe determinat color i introduint-hi el vocabulari associat. Per exemple, per al roig es pot aprofitar algun projecte sobre aliments i portar a l'aula tomàquets, maduixes, cireres, síndria, etc., a més que els infants vinguen a classe amb diferents peces de roba de color vermell. En el moment que coneguen més d'un color caldrà que contrasten objectes d'aquests colors per discriminar-los i que ho verbalitzen adequadament.

En el procés d'adquisició dels diferents colors, es fa necessari que els xiquets i les xiquetes els utilitzen per a produir representacions gràfiques pròpies en les quals aparega un color o més d'un, bé mitjançant pintura de dits, llapis de colors, ceres o retoladors, per exemple.

Una proposta per a iniciar el treball amb els colors seria començar amb el roig, el blau i el groc. Es podria continuar amb el verd i el taronja, introduint posteriorment les barreges dels colors coneguts a més del blanc i el negre, així com els tons obscur i clar dins de cada color.

C. Forma dels objectes. Aquest treball és compartit amb el de les capacitats a desenvolupar dins del tema 5 «Primeres nocions espacials i geomètriques», per aquest motiu no ens estendrem ara en la introducció geomètrica de les figures. No obstant això, considerarem la forma com una més de les qualitats que caracteritzen els objectes i que ens ajuda a descriure'ls i a reconèixer-los.

Per a treballar les figures geomètriques, prestarem atenció en un principi a cercles, triangles i quadrats, procurant que a l'aula hi haja més presència d'objectes en els quals els trobem en alguna de les seues cares i introduint el vocabulari associat (pots redons pel cercle, caixes amb alguna cara quadrada pels quadrats, envasos de sandvitx pels triangles, per exemple, com es mostra a la figura 10). Quan coneguen més d'una forma, caldrà que contrasten objectes d'aquestes formes per discriminar-les.
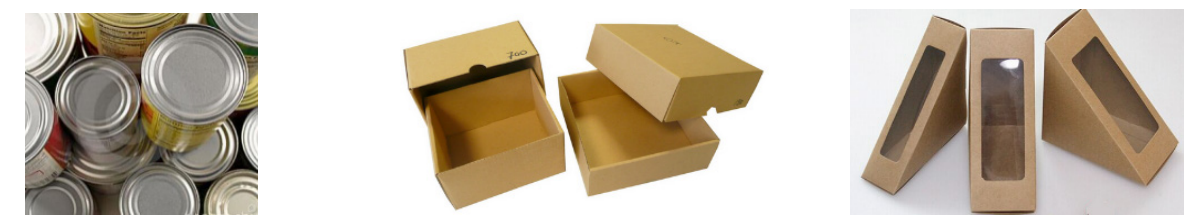

Figura 10. Imatges d'objectes per a treballar cercles, quadrats i triangles

L'aprofundiment en els conceptes geomètrics corresponents a aquestes figures planes es desenvolupa amb més detall en el tema 5 d'aquest volum. 
Cap a la meitat del $2 \mathrm{n}$ cicle $\mathrm{i}$ una vegada aquestes figures hagen estat treballades, afegirem els rectangles a partir de molts objectes quotidians que tenen alguna cara rectangular (portes, llibres, fulls, finestres, pissarres, taules, etc.).

En el procés d'adquisició de les diferents formes, cal que els xiquets i les xiquetes utilitzen diferents materials didàctics per visualitzar-les i construir-les (figures geomètriques de plàstic, blocs lògics...).

A més, treballarem també gràficament mitjançant activitats de retallar-les, acolorir-les i dibuixar-les, utilitzant inicialment figures model en cas que ho necessiten i sense model més endavant.

Caldrà introduir altres formes que no s'anomenen geomètricament de cap manera especial, per exemple, forma d'arbre, de casa, de peix, de lluna creixent... Podem treballar-les amb activitats d'encaixos en les quals diferents peces hauran d'introduir-se en forats o siluetes que tinguen la seua mateixa forma i anomenar aquestes formes (figura 11).

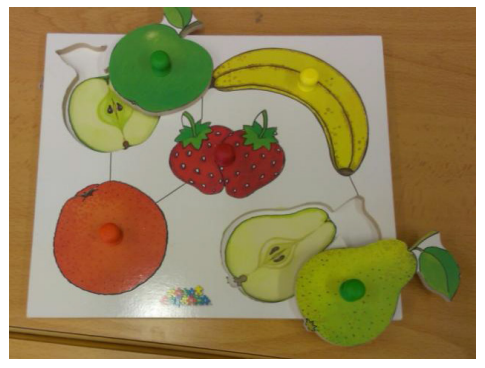

Figura 11. Imatge d'un material didàctic d'encaixos

D. Longitud dels objectes. Respecte de la magnitud longitud, i tenint en compte les diferents direccions en les quals aquesta es pot considerar, treballarem el llarg, l'alt i l'ample d'alguns objectes.

Des del començament del $2 \mathrm{n}$ cicle cal treballar els contrastos llarg-curt i altbaix utilitzant objectes de llargària i alçada molt contrastada i que siguen el més semblant possible respecte de les altres característiques que els determinen, per evitar que siguen aquestes les que centren la seua atenció (dues cordes per nugar uns paquets, dues torres fetes amb blocs per a representar els edificis del seu poble, dos camins marcats al pati per fer una carrera, dos arbres del pati...).

Més endavant, cal introduir també la diferència entre ample i estret, amb un procediment semblant a l'anterior i utilitzant objectes, el més plans possible, per poder reconèixer amb claredat la direcció en la qual observem l'amplària sense confondre-la amb la llargària (per exemple, un camí fet amb paper continu i un altre amb paper higiènic).

Progressivament s'anirà completant el vocabulari amb la introducció de modificadors per a aquestes dimensions: molt alt, molt curt, poc llarg... 
A mesura que es van adquirint aquests coneixements, es poden treballar les comparacions amb objectes que no siguen tant semblants en la resta de característiques, per a aconseguir la seua generalització (una corda i un camí en l'escenificació d'un conte; un arbre i una casa en un treball sobre les vacances; una tovallola i una banyera en un projecte sobre els habitatges familiars).

E. Grossària dels objectes. Cap al final de l'etapa i treballant en alguns objectes tridimensionals s'assimilarà aquesta característica, segons els casos, a una de les dues dimensions horitzontals. S'estudiarà el contrast gros-prim sense confondre'l amb ample-estret. Per exemple, en el cas del tronc d'un arbre, direm que és alt i gros, no alt i ample, com s'ha esmentat abans en el cas dels camins.

\subsection{Distingir característiques sensorials mitjançant el tacte}

En aquest apartat es treballaran les següents qualitats dels objectes: textura, duresa, humitat, temperatura, grandària, forma i grossària. També es dedicarà atenció als materials concrets amb els quals han estat fabricats els objectes.

A. Textura dels objectes. Iniciarem aquest treball establint diferències entre les sensacions agradables i desagradables que senten els xiquets i les xiquetes quan recorren amb la mà les superfícies de determinats objectes amb textures molt contrastades. Per exemple, es pot aprofitar un projecte sobre els oficis per portar a classe un tros de vellut $i$ un paper de vidre que utilitzen les modistes i els fusters, introduint-hi el vocabulari associat, suau i aspre, respectivament, per expressar-les.

Més endavant, a més de percebre les anteriors textures, experimentaran sensacions diferents en tocar alguns objectes, per exemple, en un treball de classe relacionat amb els aliments, una poma i un alvocat sense pelar. El vocabulari que s'introduirà per tal d'anomenar-les serà ara llis i rugós, respectivament, per diferenciar les superfícies que no presenten plecs o irregularitats de les que si ho fan.

Caldrà buscar exemples que mostren les relacions que es poden establir entre aquestes textures. Així, trobarem en diferents situacions que es treballen a l'aula, teixits com per exemple la pana que és rugosa i suau alhora, la superfície d'un full que és llisa i suau i un fregall que és rugós i aspre.

B. Duresa dels objectes. En el contacte que l'alumnat té amb els objectes, a més de percebre les textures de les seues superfícies, també pot apreciar la resistència que presenten a ser deformats quan s'exerceix una força sobre ells. Així, per exemple, en una situació d'elaboració d'un regal per algun familiar, en què han de pintar una pedra o un tros de fusta $i$ envernissar-les amb un cotó, experimentaran les diferències entre aquests materials i les anomenaran amb els adjectius dur i tou, respectivament. 
C. Humitat dels objectes. Quan realitzen activitats en les quals intervinga el seu contacte o el d'altres objectes amb aigua, diferenciaran entre sec i banyat, per exemple, introduint les mans davall del raig de l'aixeta quan se les renten abans d'esmorzar i comparant-les una vegada se les han eixugat. Posteriorment, caldrà afegir nous matisos, noves sensacions d'aquesta qualitat, així, entre banyat i sec es podria situar la sensació d'humit, tocant la terra d'un test que forma part de les plantes que es cuiden a l'aula i que haja estat regada amb suficient antelació o la tovallola amb què ja s'han eixugat les mans. En tots els casos, l'alumnat ha d'utilitzar el vocabulari associat.

D. Temperatura dels objectes. A més de les qualitats anteriors, quan els xiquets i les xiquetes entren en contacte amb objectes també perceben la seua temperatura, per exemple, quan toquen el vidre de les finestres, el radiador de la calefacció, quan mengen un gelat o sopa... Les referències a aquesta qualitat s'anomenen fred i calent, i normalment formen part del seu bagatge vital previ. Afegirem nous matisos respecte d'ella parlant de temperat, que es situaria entre el fred i el calent, quan toquen, per exemple, a altre company, quan xafen descalços el tatami de psicomotricitat o toquen un got de llet que s'haja calfat un poc al menjador de l'escola.

E. Grandària, forma i grossària dels objectes. Totes les matisacions respecte a aquestes tres qualitats que s'han tractat per la vista es treballaran també amb el tacte, realitzant activitats en les quals l'alumnat manipule objectes que no puguen veure per a reconèixer i verbalitzar les seues característiques, que hauran conegut $\mathrm{i}$ treballat prèviament per la vista.

F. Materials concrets. Caldrà completar tot el treball anterior amb el reconeixement pel tacte de materials quotidians, com la fusta, el vidre, el metall, el paper, el plàstic, les teles, el marbre... Seran les combinacions de les anteriors qualitats, les que els permetran identificar-ne un o altre. Per exemple, llis, fred i suau són característiques del vidre; temperat, rugós i suau corresponen a la pana... El treball de trobar quin és quin els farà aprofundir en la reflexió sobre allò que el tacte els diu.

L'estudi de cadascuna de les característiques tàctils que acabem d'esmentar comença amb la diferència entre grans contrastos i es matisa a poc a poc al llarg del $2 \mathrm{n}$ cicle amb la introducció dels modificadors molt, poc, etc. (molt banyat, molt suau, poc fred...).

\subsection{Distingir caracteristiques sensorials mitjançant l'olfacte}

L'olfacte és un dels cinc sentits que ens apropa a allò que ens envolta. Però de la mateixa manera que el tacte i la vista ens donen una informació prou objectiva de la realitat, no passa tant amb l'olfacte. Aquest és molt més subjectiu. És evident que hi haurà olors que obtindran el consens generalitzat, allò que faça molt mala olor $\mathrm{o}$ allò que en faça de molt bona. Però tot i així, aquest sentit junt amb el del 
gust, entra dins de la part més personal que tenim en accedir a allò que ens sembla la realitat.

Al llarg del 2n cicle caldrà incidir en diferències molt marcades entre objectes 0 coses que facen bona olor, mala olor i que no en facen gens. Cal dir que les dues primeres sensacions no plantegen cap dificultat per ser molt fàcil trobar objectes que les provoquen (perfum, xocolata, amoníac, peix...). L'absència d'olor és més complicada de treballar, perquè resulta difícil aïllar un objecte inodor d'altres que l'envolten per a aconseguir que la sensació siga real. Per exemple, si volem olorar aigua destil·lada haurem d'utilitzar un got de vidre per evitar les interferències olfactives dels envasos de plàstic.

En general, els xiquets i les xiquetes diferenciaran entre allò que els resulta agradable, allò que no els ho resulta o allò que no els provoca cap sensació d'aquest tipus, proporcionant-los diferents elements que oloraran amb els ulls tapats o tancats, verbalitzant les seues percepcions. El material que utilitzarem per a aquestes activitats s'obtindrà directament d'elements presents en l'aula o d'altres que portaran de casa per indicació nostra i que estaran relacionats amb el desenvolupament d'algun projecte o situació d'aula.

En la segona meitat del cicle, el treball se centrarà a associar aromes, perfums, olors tant de bo siguen agradables com no, als elements que els produeixen (taronja, pintura, xoriç, crema corporal, lleixiu, clavegueram brut...).

\subsection{Distingir característiques sensorials mitjançant el gust}

El gust és un sentit molt important en la vida de les persones perquè està lligat al plaer de menjar. De manera anàloga al sentit de l'olfacte, al qual està freqüentment unit, el gust també està lligat al subjectivisme, encara que hi ha alguns sabors reconeguts de manera universal que cal aprendre per tal de poder descriure allò que degustem.

Al començament del cicle cal diferenciar clarament entre allò que és dolç, salat o insípid (galetes, xocolata, llepolies...; papes, pipes...; aigua...) sabent que l'absència de sabor és complicada de treballar per raons semblants a les de l'olfacte.

Més endavant s'ampliarà a altres sabors, com ara àcid i amarg. Caldrà trobar-los exemples propers per tal que fixen el sabor. Així, el iogurt natural sense sucre o la llima tenen un gust àcid i el pomelo, les tiges de les carxofes, la tònica o el bíter sense alcohol, el tenen amarg.

Els xiquets i les xiquetes distingiran entre dolç, salat, àcid i amarg, assaborint diferents elements amb els ulls tapats o tancats i evitant, dins del possible, interferències de l'olfacte. Utilitzarem per a aquesta tasca objectes o elements presents a l'aula o que hagen portat de casa per indicació nostra i que novament formaran part de l'activitat habitual de classe. 
Completarem aquest treball desenvolupant la capacitat d'associar alguns sabors fàcils d'identificar als elements que els produeixen (crema de xocolata, pernil, poma, llima, taronja...).

De manera anàloga als altres sentits, podem anar matisant a poc a poc les diferències de sabors amb la introducció dels modificadors molt, poc, etc. (molt dolç, molt àcid, poc salat...).

\subsection{Distingir característiques sensorials mitjançant l'oüda}

Generalment, s'entén per educar l'oïda un treball musical, però el nostre objectiu és només reconèixer sons, distingir-los i saber d'on vénen. Per a això treballarem amb l'alumnat la identificació dels que habitualment troben al seu voltant i la verbalització del seu origen d'acord a les nocions d'orientació espacial.

Començarem per sons quotidians, com ara els que provenen del carrer (d'una motocicleta, d'un clàxon, d'unes campanes...), de casa (del timbre, de la ràdio, de la rentadora...), del col·legi (música d'inici, del colp d'una porta, de l'ordinador...), etc. També els que poden estar presents en diferents llocs alhora.

Posteriorment, distingiran els sons ambientals dels més musicals i els que els resulten agradables dels que no.

Intentarem que associen de manera inequívoca alguns sons concrets als llocs en els quals es produeixen i que discriminen clarament els que no es corresponen, per exemple serà usual sentir la rentadora en l'àmbit de la llar, però no a l'aula.

\section{Descriure diverses caracteristiques que té un objecte}

En el moment que som capaços de descriure algunes característiques dels objectes de l'entorn, estem preparats per transmetre als altres els aspectes de la realitat que hem pogut conèixer. Aquests passos inicials són essencials per tal de poder agrupar i relacionar els objectes, que és el nostre darrer objectiu. S'ha intentat estimular, des del punt de vista de l'anàlisi, els sentits que capten i s'apropien de les característiques de tot el que els envolta. Una vegada interioritzades aquestes per l'alumnat, se'ls demanarà el següent pas que consistirà a transmetre el que han percebut, mitjançant la descripció de les propietats dels objectes.

Aquest treball és per a tot el $2 \mathrm{n}$ cicle d'infantil i la dificultat serà creixent $\mathrm{i}$ adequada al seu nivell. Cada vegada els exigirem descripcions més acurades, amb més característiques i més completes. Per exemple, si es tracta de descriure una pilota, en un principi serà suficient dir que és rodona, més endavant esperarem que afegisquen gran, blava, dura, rugosa, etc. 


\section{Descriure diverses caracteristiques que no té un objecte}

En moltes situacions de la vida diària, el nostre pensament a l'hora de descriure objectes es refereix a característiques en negatiu, és a dir, es fixa en aquelles característiques que un objecte no té (perquè ens agradaria que les tingués, perquè el comparem amb un altre que sí que les té...). Per exemple, quan descrivim un cotxe puntualitzem que no té sostre plegable, o que no és elèctric, o que no és un $4 \times 4$.

Aquest treball és, en general, més complicat que el de les descripcions anteriors, en les quals es descobreixen les qualitats que sí estan presents i es verbalitzen, perquè requereix pensar en aquelles que no es veuen i ser capaços d'argumentar que no hi són presents.

Evidentment, és també més complicat per als nens i nenes d'educació infantil i, en moltes ocasions, és més anàrquic i autònom que controlar les qualitats que sí hi són presents en els objectes a descriure. Per exemple, les coses roges són únicament roges, però les que no ho són, poden ser blaves, grogues, verdes...

Ho treballarem en la segona meitat del $2 \mathrm{n}$ cicle i, si no hi troben les característiques que no són presents, podem ajudar-los amb preguntes específiques respecte a elles o comparant l'objecte a descriure amb altre o altres que sí les tinguen. Per exemple, si esperem que ens diguen d'una carpeta que no és de cartó, podem comparar-la amb una altra que sí que ho siga perquè descobrisquen la diferència. Així mateix, es poden fer aquests tipus d'activitats utilitzant els blocs lògics de Dienes com una ajuda molt valuosa per treballar aquesta capacitat.

Quan hagen descrit objectes utilitzant de forma separada les dues maneres de expressar les seues característiques, estaran preparats per a usar en les seues descripcions expressions combinades en les quals es referisquen tant a característiques presents en un determinat objecte, com a les que no ho són.

\section{Reconèixer característiques d'objectes representats en imatges}

Per a ampliar el desenvolupament de les capacitats de descripció de característiques, l'alumnat treballarà també, en els dos últims cursos de l'etapa, amb objectes que no puguen manipular, sinó que sols observen en representacions gràfiques de diversos tipus: dibuixos, revistes, pòsters, fotografies, catàlegs..., relacionats amb diferents projectes o situacions de treball que es duguen a terme a l'aula.

Evidentment, es tractarà d'objectes coneguts i propers als xiquets i les xiquetes, que hauran manipulat amb anterioritat $\mathrm{i}$ que ara han de descriure sense tenir-los davant físicament.

En aquestes descripcions el sentit que més usen és el de la vista i sempre comencen anomenant les característiques visuals que observen. Cap al final del cicle s'intentarà que també expliciten en aquestes descripcions característiques que puguen 
haver conegut amb anterioritat respecte dels altres sentits, i que estiguen presents en els objectes treballats. Han d'imaginar, han de fer l'esforç de recordar com és eixe objecte en la realitat per tal de fer una descripció el més fidel possible. Per exemple, començaran descrivint una taronja dient que és rodona i de color taronja, però més endavant hauran de saber dir que és dura, rugosa, àcida, humida en l'interior i seca en l'exterior...

\section{Identificar objectes determinats per diverses de les seues característiques}

La construcció del coneixement es completa realitzant activitats inverses a les de les capacitats 2 i 3 . En aquest cas, i a partir d'una descripció que els proporcionarem, hauran de trobar l'objecte susceptible d'acomplir-la. Però abans han d'estar entrenats en el que suposa la descripció per tal d'entendre els mecanismes que la condueixen.

Es treballarà en tot el $2 \mathrm{n}$ cicle $\mathrm{i}$ es poden usar, com a complement, jocs d'endevinalles o el joc del veig-veig. Normalment, en les primeres activitats d'aquests tipus, serà el mestre qui descriga l'objecte que ha de trobar l'alumnat. Cap al final de l'etapa poden ser ells qui facen la descripció, perquè d'altres troben l'objecte.

Cal notar que si sols estem buscant objectes que acomplisquen unes característiques determinades, poden haver-hi diversos que servisquen com a resposta. Pel contrari, si estem jugant a endevinalles o al veig-veig, sols servirà un objecte concret com a resposta a la descripció plantejada.

\section{Identificar diversos elements que tenen una mateixa característica}

Fins ara el que interessava era descriure les qualitats que té un objecte i per això hem dotat l'alumnat d'eines per fer-ho.

Com a complement farem un treball que necessita un poc més d'abstracció, en el qual ens interessarà la característica o qualitat comuna a objectes varis.

Es tracta ara que els xiquets i les xiquetes, en desenvolupar alguna de les situacions que es treballen a l'aula, agrupen uns quants objectes que tenen una mateixa característica, per exemple, que agafen tres llapis rojos de la safata dels colors per tal de pintar el mural o que porten unes quantes teles llises que hi ha al racó de les disfresses.

Aquestes tasques es realitzen a tot el $2 \mathrm{n}$ cicle d'infantil i constitueix el primer pas, per a la tasca posterior de formar conjunts, que s'estudiarà en la capacitat següent. Només és un primer pas, perquè fins que no es demanen tots els elements del conjunt referencial que tenen una característica comuna, no es formarà vertaderament eixe conjunt. 


\section{Formar conjunts segons característiques sensorials dels objectes}

Com es comenta en el punt 3.1, el treball a l'aula d'educació infantil ha de possibilitar que els xiquets $i$ les xiquetes avancen «des d'un coneixement físic dels objectes fins a un coneixement lògico-matemàtic dels mateixos, que els permeta agrupar-los i relacionar-los en funció de les seues semblances o de les seues diferències».

Fins ara s'ha desenvolupat un treball més centrat en els aspectes físics dels objectes contemplats de manera individual, mentre que a partir d'aquesta capacitat els considerarem agrupats o relacionats entre ells per avançar en el coneixement lògico-matemàtic abans esmentat.

Per tal de realitzar les activitats de formació de conjunts, cal tenir en compte les següents orientacions:

1. Sempre que siga possible, cal usar els nens i nenes com a elements del conjunt. Per exemple, formar un conjunt amb tot l'alumnat que haja dut fruita per esmorzar.

2. Fixar molt clarament el conjunt referencial, per delimitar sense cap mena de dubte els objectes amb els quals han de treballar. Per exemple, si es vol formar un conjunt de peces de construcció de fusta, aclarir molt bé que s'han de treure d'una caixa determinada on hi ha els que ens interessen, evitant així que puguen dispersar-se buscant per tota la classe.

3. Usar llocs diferents per tal de formar els conjunts i que no siga sempre en el terra o en les taules, per tal de possibilitar la generalització del concepte. Per exemple, reconèixer el conjunt de xiquets i xiquetes que formen un grup determinat dins de l'aula tant si són a la taula de treball, a l'estora de l'assemblea o com si es troben al pati.

4. En el cas d'utilitzar diagrames per a representar conjunts, aquests han de ser de diferents formes (triangulars, rectangulars...) per tal de facilitar l'esmentada generalització de la idea de conjunt i evitar que s'associe només als diagrames de Venn.

5. Treballar amb propietats característiques clares $i$ apropiades a les edats de l'alumnat. Per exemple, no és convenient formar un conjunt de motxilles pel seu preu, sinó pel seu color.

6. Utilitzar diferents situacions d'aula per a treballar els conjunts, sabent que ens poden ajudar a desenvolupar altres conceptes i a resoldre altres situacions problemàtiques.

L'extensió d'aquesta capacitat aconsella fraccionar-la en apartats diferenciats i ordenats per la seua dificultat a l'aula d'infantil. 


\subsection{Formar conjunts determinats per una característica enunciada de manera afirmativa}

Començarem amb situacions reals molt properes als xiquets i les xiquetes, que els interessen i amb les quals es pugen sentir identificats. S'ha d'insistir en la necessitat d'agrupar tots els elements d'un conjunt referencial que acomplisquen una característica concreta perquè estiga correctament format el conjunt que aquesta determina.

Les indicacions que donarem a l'alumnat referents a la formació de conjunts es referiran només a una característica que serà comuna a tots els elements que ens interessen, a més de ser molt clara i coneguda per ells i elles (per exemple colors, formes, grandàries...). Caldrà fixar clarament el referencial i usar la paraula tots entenent-la com la que ens obliga a no deixar d'agafar cap element que hauria de formar part del conjunt. Un exemple d'aquest treball podria ser: «En una situació d'aula en la qual els xiquets i les xiquetes estan preparant material per a pintar un dibuix, els demanem que del pot dels llapis de colors traguen tots els que són verds», i un altre exemple: "Al voltant d'una activitat d'educació física en la qual cal fer una cursa en el pati, els demanem que es col-loquen junts, en un lloc determinat, tots els que porten calçat esportiu».

En els primers passos d'aquesta tasca pot produir-se l'anomenat error de contaminació, (segons Piaget) que consisteix a canviar la característica que determina el conjunt que estan formant per una altra d'algun o alguns elements ja incorporats al conjunt, que en eixe moment cobra més interés pels xiquets i les xiquetes (habitualment trien una característica de l'últim element que han seleccionat per formar part del conjunt, com es pot veure en la figura 12). Per exemple, suposem que d'un conjunt referencial format per unes quantes peces dels blocs lògics, es demana reunir totes les peces de color blau per a fer amb elles una torre. En un moment de la tria un xiquet o xiqueta elegeix un cercle blau. L'error de contaminació es manifesta quan a partir d'eixe moment comença a triar cercles oblidant el color blau i contaminant aquesta característica amb la de cercle. No és que no hagen entés el que havien de fer, és que la seua atenció se centra a partir d'una determinada peça en un altre interés, en una altra característica.

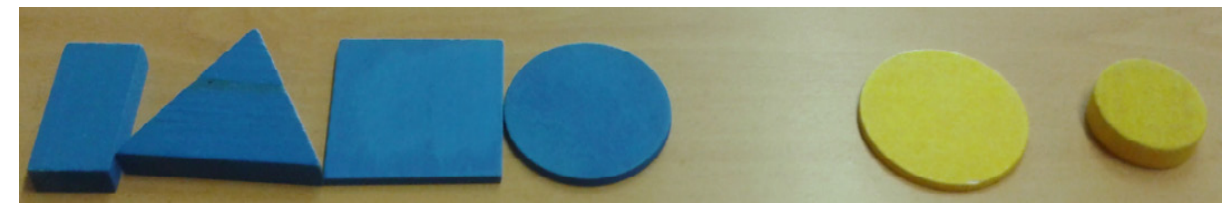

Figura 12. Representació d'un exemple d'error de contaminació

Com que aquest problema es presenta amb més freqüència quan el referencial té molts elements i el conjunt que hem de formar també té un cardinal elevat, començarem treballant la formació de conjunts on no hi haja molts elements, a partir de referencials els cardinals dels quals no siguen molt elevats.

En qualsevol cas, si es produeix l'error de contaminació i per ajudar-los a superar-lo els farem preguntes comparant l'element incorrecte amb els que havien 
agafat al principi i reflexionant amb ells i elles sobre quina era la característica que determinava el conjunt per fer-los detectar la seua equivocació i donar-los la possibilitat d'esmenar-la. En l'exemple anterior, si agafen un cercle groc els preguntarem quin color tenen totes les peces anteriors, perquè s'adonen que la característica comuna és el color blau i no la forma cercle.

Quan l'alumnat acabe la tasca de formar un conjunt, parlarem amb ells i elles per recordar quina era la propietat característica que determinava el conjunt i preguntant-los si estan tots els elements que l'integren, si no n'han deixat cap fora i fixant així, definitivament, la característica del conjunt format.

Més endavant, farem el mateix tipus d'activitats i anirem augmentant el nombre d'elements del referencial i dels conjunts que formen, insistint en la necessitat que estiguen tots els elements que tenen una característica comuna per tenir format el conjunt.

Com els xiquets i les xiquetes van coneixent cada vegada més característiques dels objectes, podrem utilitzar també les noves (longitud, amplària, textura, etc.) per a ampliar les possibilitats de formació de conjunts que existien al començament d'aquest treball.

Per a referir-se als grups d'objectes formats, el docent usarà la paraula conjunt (hem format el conjunt dels llapis verds, de les peces grogues, dels xiquets i les xiquetes amb dos germans...) fins que aquesta passe, avançada l'etapa d'infantil, a formar part del vocabulari habitual de l'alumnat per designar els grups d'elements amb una característica comuna.

Les confusions que es produeixen quan es formen els conjunts, motivades per l'error de contaminació abans esmentat, van desapareixent a mesura que l'alumnat creix i, normalment, estan totalment superades cap al final d'aquesta etapa.

\subsection{Formar conjunts determinats per una característica enunciada de forma negativa}

Una vegada treballada la capacitat 3 i recorreguts els primers passos de la 7.1, es pot iniciar la formació de conjunts utilitzant per determinar-los característiques enunciades de forma negativa (al cas anterior dels llapis de colors, els demanaríem tots els que no són rojos, per exemple).

És una manera de formar conjunts més complicada que la anterior i, generalment, va acompanyada de preguntes de l'alumnat com «però, vols els grocs, els blaus o quins?». Front a aquests interrogants ens mantindrem en la negació de la característica indicada, «els que no són rojos», per ajudar a què es produïsca en els xiquets $i$ les xiquetes el pensament que els permeta discriminar la informació i esbrinar quins són els elements que ens interessen, com es pot veure en la figura 13. 


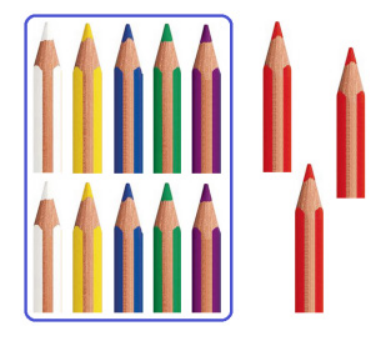

Figura 13. Representació d'un conjunt determinat per una característica negativa

Aquest treball comparteix amb la capacitat anterior el fet d'entendre i utilitzar adequadament les paraules tots i conjunt, l'última només per part del docent en un principi i per tot l'alumnat al final de l'etapa.

\subsection{Formar conjunts determinats per una característica i observar el conjunt que determina la seua negació}

Fins ara s'ha treballat per separat la formació de conjunts determinats per característiques enunciades de forma afirmativa i de forma negativa. El que es pretén en aquesta capacitat és reflexionar amb els xiquets i les xiquetes perquè s'adonen del fet que sempre que formen un conjunt determinat per una característica afirmativa, apareix format automàticament el que té com a característica la negació de l'anterior. Per exemple, relacionat en una situació d'aula en la qual s'estan treballant els aliments, han format el conjunt de «xiquets i xiquetes que han portat fruita per esmorzar» a partir del referencial de tot l'alumnat de la classe; tots els que no s'han incorporat a aquest conjunt formen per la seua part un altre conjunt la característica del qual és «no haver portat fruita per esmorzar». En la figura 14, en un exemple amb les peces grans dels blocs lògics, es veu clarament com la formació del conjunt dels cercles implica immediatament la del conjunt dels que no són cercles.

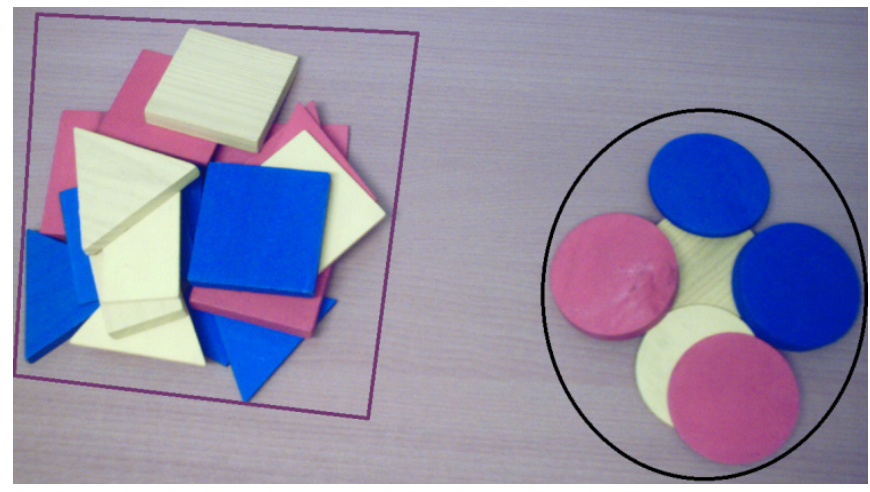

Figura 14. Representació d'un conjunt de cercles i d'un altre que no ho són

En el fons el que s'està treballant és el concepte de conjunt complementari, encara que no és necessari utilitzar aquest vocabulari amb els xiquets i les xiquetes. Com que el desenvolupament d'aquesta capacitat exigeix conèixer en profunditat les dues maneres de formar conjunts que s'han treballat en la 7.1 i la 7.2, deixarem aquesta tasca per a l'última part del $2 \mathrm{n}$ cicle. 
És important reflexionar amb l'alumnat al voltant de les propietats característiques dels dos conjunts i de la presència respectiva en cadascun d'ells de tots els elements que les acompleixen. També haurem de conversar amb l'alumnat al voltant de les característiques dels conjunts per tal de verbalitzar correctament tant la que és afirmativa (conjunt de cercles) com la seua negació (conjunt dels que no són cercles).

Igualment, aprofitarem aquesta capacitat per reforçar l'ús adequat de les paraules tots i conjunt, de manera anàloga als casos anteriors.

\subsection{Formar conjunts determinats per més d'una característica comuna}

També en el darrer curs i com a complement i ampliació del que ja s'ha treballat en les capacitats anteriors, s'inicia la formació de conjunts determinats per diverses característiques comunes. Evidentment, el primer pas serà utilitzar sols dues (per exemple, en una activitat de decorar un mural, els demanem que porten de l'armari del material escolar tots els pots de pintura de dits de color vermell) i, si es veu que no presenta molta dificultat, ampliarem les característiques fins que els conjunts en queden determinats per tres o quatre. Aquesta última possibilitat es donarà generalment quan els xiquets i les xiquetes es troben en una situació molt propera $\mathrm{i}$ amb molt d'interés per a ells, en la qual intervinguen materials o objectes les característiques dels quals siguen molt conegudes i estiguen molt ben estructurades, com ocorre en el cas dels blocs lògics.

Més endavant, es pot ampliar la dificultat combinant alguna característica enunciada de forma afirmativa amb una altra de forma negativa (d'entre tot l'alumnat de la classe i per fer un determinat joc han de triar les que són xiques i no porten calçat d'esport, per exemple).

També dedicarem atenció al reforç del vocabulari associat i al seu ús adequat.

\section{Enumerar els elements que formen part d'un conjunt i reconèixer alguns que no en formen part}

De manera complementària a la tasca de formar conjunts, potenciarem en l'alumnat la realització d'un treball de revisió d'allò que han fet i d'explicació de les raons per les quals hi ha en el conjunt uns determinats elements i uns altres no. Aquesta activitat de reflexió els permet passar d'una visió més general del conjunt i de la seua propietat característica, a una altra de més analítica, que posa la mirada en els elements un a un i comprova la seua idoneitat en l'àmbit del conjunt format.

L'anàlisi reflexiva dels elements els ha de dur a adonar-se que cadascun d'ells pot estar en diferents conjunts segons la característica principal que es trie. Eixos elements pertanyen a un conjunt perquè hi ha un criteri basat en una determinada propietat característica que els ha reunit i que no és incompatible amb altres 
criteris que situen alguns elements en conjunts diferents (un determinat retolador pot formar part d'un conjunt de retoladors, d'un de retoladors amb tapadora, d'un d'objectes d'escriptura verds...).

Es desenvoluparà aquesta capacitat durant tot el 2 n cicle d'infantil i s'utilitzarà en els dos darrers anys el vocabulari pertànyer i no pertànyer per expressar la relació que existeix entre els elements i els conjunts, per exemple, el retolador verd pertany al conjunt d'objectes d'escriptura verds.

\section{Identificar la propietat característica que determina un conjunt}

Fent referència de nou a la reversibilitat en la construcció del coneixement, treballarem amb l'alumnat perquè siguen capaços d'identificar la propietat característica d'un conjunt que ja està format, és a dir, perquè troben el criteri pel qual hem agrupat uns determinats elements. Evidentment, es tractarà d'una sola característica que, a més d'estar present de manera afirmativa, serà clara i coneguda pels xiquets i les xiquetes.

Aquesta tasca no pot realitzar-se fins que no estiga treballada la formació inicial de conjunts i l'alumnat haja incorporat l'agrupament d'elements com una acció habitual en les seues activitats. És per això que no desenvoluparem aquesta capacitat fins a la segona meitat del 2 n cicle d'educació infantil.

Quan els preguntem: Com són els elements d'un conjunt?, en què s'assemblen?, per què els hem agrupat així?, la contestació adequada ha de servir per explicar la propietat característica que ens ha permès reunir-los. En principi, no els resulta fàcil de trobar-la. La tasca d'abstraure la propietat comuna a partir de l'anàlisi dels elements del conjunt és prou més difícil que la de triar els que acompleixen una determinada característica explícita. Amb molta freqüència resulta necessària la intervenció del docent per a aconseguir que siguen capaços de trobar la propietat que s'està buscant. Mitjançant preguntes d'ajuda (com és aquest?, i aquest?, s'assemblen?, com són tots?...) el docent intentarà que els xiquets i les xiquetes comparen les característiques dels diferents elements del conjunt i detecten quina és la que està present en tots ells.

En el desenvolupament d'aquestes activitats es presenta de vegades l'anomenat error de limitació (segons Piaget). Es produeix en els primers moments de treballar la capacitat i consisteix en limitar la propietat general del conjunt per altres característiques que sols compleixen uns quants elements del mateix. Per exemple, si tenim format un conjunt amb totes les peces triangulars dels blocs lògics (figura 15), en lloc de descobrir el fet de ser triangle com la propietat buscada, ens diuen que tenen un conjunt amb «peces grogues, blaves i roges» o un conjunt de «peces grans i petites»,. Per ajudar-los a superar aquest error és necessari interactuar amb ells utilitzant les preguntes esmentades abans, per a potenciar la reflexió que els permeta abstraure la característica buscada. 


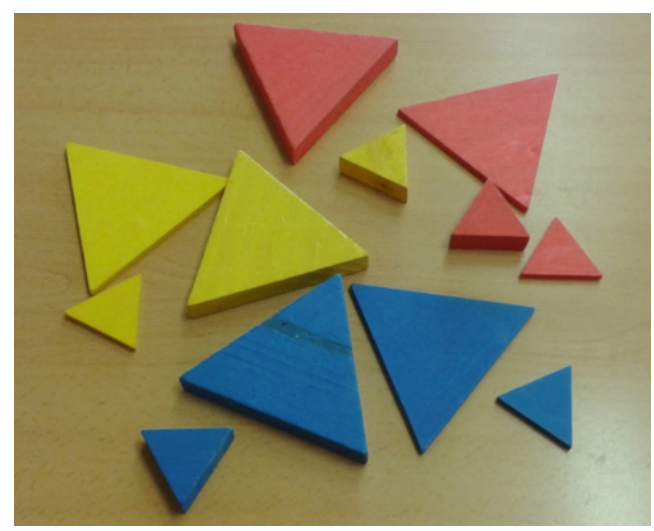

Figura 15. Representació d'un exemple per a il·lustrar l'error de limitació

Cap al final de l'etapa ja no es produeix aquest error de limitació i poden trobar ells i elles a soles la propietat característica afirmativa d'un determinat conjunt. Com a complement d'aquest treball podem intentar la identificació de la propietat característica d'un conjunt quan hi estiga present de manera negativa, encara que és més difícil i pot ser que no es puga aconseguir en educació infantil, llevat que s'utilitzen materials amb característiques que els siguen molt conegudes (cercles no vermells, per exemple).

\section{Formar conjunts a partir d'elements representats en imatges}

Tot el que s'ha comentat en les capacitats anteriors respecte de la formació de conjunts es refereix a situacions on els elements són objectes reals que es troben a l'abast de l'alumnat per poder manipular-los i agrupar-los. En els dos últims cursos de l'etapa es poden plantejar també activitats en les quals siga necessari formar conjunts treballant amb representacions gràfiques (pòster, revista, catàleg, fotografia, activitat de transferència...) on els elements del conjunt referencial ocupen tot el paper $i$ els del conjunt que volem formar estan disseminats entre els altres. Es tracta d'indicar quins són els elements que ens interessen utilitzant una marca gràfica que els distingisca, per exemple, en una imatge que conté diferents animals i que s'està treballant a l'aula amb motiu de la visita a una granja- escola, els demanem que marquen d'alguna manera les vaques per retallar-les després.

Podem usar diferents sistemes de representació que recorreran els següents passos:

1. Ratllar, pintar del mateix color o posar una marca similar sobre els elements del conjunt que es vol formar. Encara no utilitzem el diagrama clàssic. A l'exemple de les vaques, les marcarien amb una creu de color roig, com es mostra a la figura 16. 


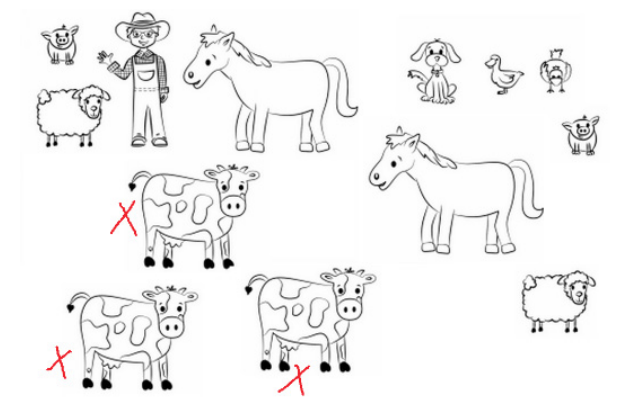

Figura 16. Representació amb creus de la selecció dels elements d'un conjunt

2. Arrodonir individualment cada element que forma part del conjunt, sense utilitzar encara un diagrama comú per a tots. En el mateix exemple, l'alumnat encercla cada vaca amb una línia tancada de color verd, com es mostra a la figura 17.

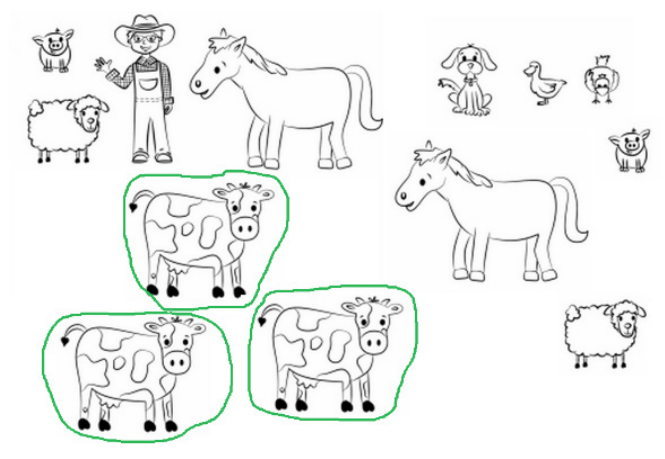

Figura 17. Representació amb diagrama individual de la selecció dels elements d'un conjunt

3. Introduir el diagrama que englobe tots els elements que formen el conjunt, com una línia tancada que ens permet separar els elements que ens interessen dels que no. Seguint amb l'exemple de la granja, els xiquets i les xiquetes han rodejat totes les vaques amb una línia tancada de color morat, com es mostra a la figura 18 .

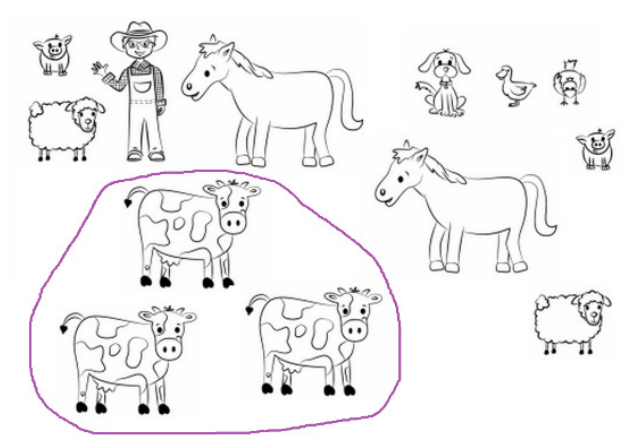

Figura 18. Representació amb un únic diagrama dels elements d'un conjunt 
En tot aquest treball és important recordar l'orientació 4 de la capacitat 7, en la qual es recomana utilitzar diagrames de diferents formes per a representar conjunts, per tal de facilitar la generalització del concepte.

\section{Representar gràficament els conjunts formats}

Aquesta capacitat intenta avançar amb l'alumnat en la part del simbolisme. Es pretén que puguen ser capaços de traslladar al paper conjunts que han format en la realitat. Aquesta acció s'ha de justificar des de la necessitat de fer-ho per «guardar-ho», per «recordar-ho», per «no oblidar-nos a l'hora d'explicar-ho a casa» o «a un altre grup de companys i companyes del col·legi», per exemple. S'ha d'entendre la representació com una cosa útil perquè siga motivada la seua construcció.

Normalment es treballa en el darrer curs de l'etapa i forma part de l'inici dels xiquets i les xiquetes en el llenguatge matemàtic, atenent a raons d'economia d'escriptura, d'exactitud en la transmissió de la informació... Per exemple, hem format dos conjunts, un amb algunes xiquetes per representar un conte i un altre amb uns quants xiquets per representar-ne un altre. Aleshores anotarem els noms de cadascun d'ells i els envoltarem per separat amb dos diagrames.

Hem de recordar la importància d'utilitzar diagrames diferents i d'observar que el conjunt existeix amb independència del diagrama, que aquest sols actua com una frontera que ens ajuda a localitzar els elements que ens interessen tancant-los en el seu interior i separant-los de la resta.

\section{Trobar diferències entre els elements d'un conjunt determinat per una característica i formar subconjunts a partir d'elles}

Quan s'ha format un conjunt, tots els elements del conjunt referencial que acompleixen la característica que el determina estan inclosos en ell, però cal adonar-se que, a més de l'esmentada característica, alguns d'aquests elements poden tenir una altra o altres qualitats comunes. Eixe és l'objectiu, observar-los i intentar agrupar aquests elements en altres conjunts que anomenarem subconjunts de l'inicial (prefix sub per trobar-se dins d'un altre).

Per exemple, si construïm el conjunt de les peces grans dels blocs lògics, a dintre d'ell tenim peces de diverses formes. Aleshores, un subconjunt que podem trobar és el dels triangles grans, com es mostra en la figura 19. 


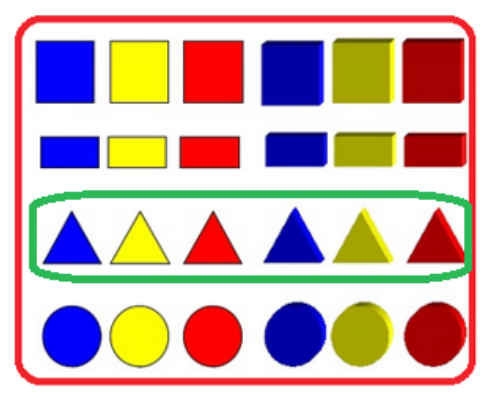

Figura 19. Representació del subconjunt de triangles dins de les peces grans dels blocs lògics

La complicació d'aquest treball està relacionada amb la dificultat de l'alumnat per realitzar classificacions jeràrquiques d'elements, fet que provoca l'oblit per part de molts xiquets i xiquetes de la característica que determina el conjunt inicial del qual s'ha tret el subconjunt i la identificació d'aquest últim sols per la segona característica observada. Caldrà fer-los conscients que les peces del subconjunt acompleixen la condició de ser grans i triangles, és a dir, verifiquen les dues propietats característiques considerades $i$, per tant, pertanyen als dos conjunts.

Evidentment, per tal de desenvolupar aquesta capacitat, caldrà haver treballat amb anterioritat la formació de conjunts determinats per dues característiques. Serà per això que la reservarem per a l'últim curs d'educació infantil.

\section{Classificar elements per semblances qualitatives}

La paraula classificar té la mateixa etimologia que classes, i també un significat semblant en el context en el qual ens trobem. Classificar elements és una tasca associada a l'existència d'una relació binària d'equivalència, que ens permet agrupar-los reunint en un mateix conjunt els elements que es relacionen precisament per la RBE definida (vegeu 2.4 d'aquest tema). Per exemple, en el conjunt de peces dels blocs lògics, la relació «ser del mateix color» és d'equivalència i classifica els blocs en tres conjunts. Les classes d'equivalència seran les agrupacions que formarem amb els elements que són equivalents per la relació. En l'exemple anterior, els tres grups formats són la classe dels blocs lògics rojos, la dels blaus i la dels grocs. Perquè una classificació estiga ben realitzada tots els elements del conjunt referencial han de pertànyer a alguna de les classes d'equivalència i cap d'ells pot formar part de dues classes alhora.

Cal diferenciar aquest concepte del de formar un conjunt perquè, encara que mantenen una dinàmica que podríem dir semblant, en acabar les dues accions el resultat no ho és tant. Podem establir tres diferències clares, treballant en un conjunt referencial qualsevol:

1. Propietat front a valor. Quan es classifica, es defineix la relació d'equivalència en funció d'una propietat general dels elements, per exemple «ser del mateix color» en un conjunt format per algunes peces dels blocs lògics que s'ha triat com a referencial (figura 20, esquerra). La formació d'un conjunt 
es realitza a partir d'un valor concret d'alguna de les propietats dels elements, per exemple «ser roges» en el referencial anterior (figura 20, dreta).
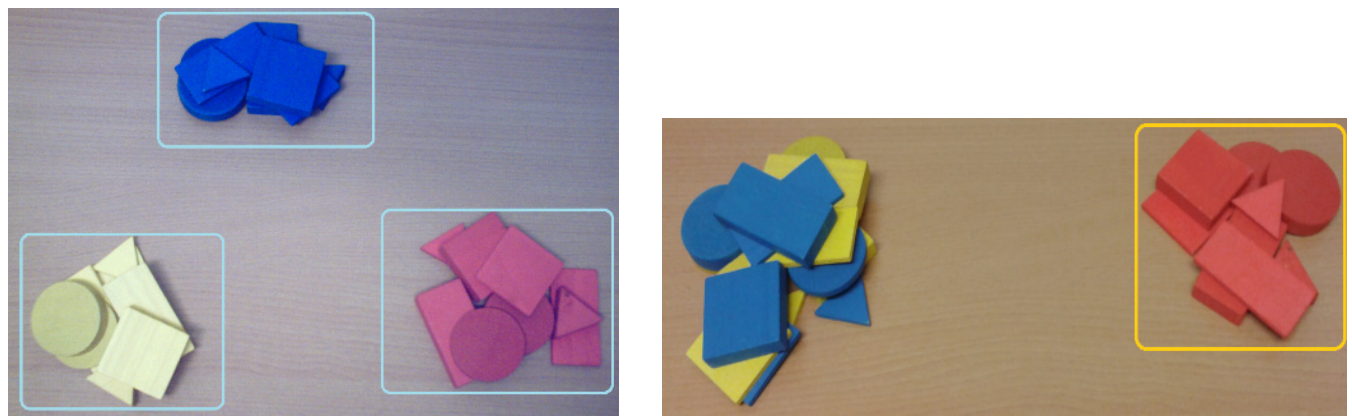

Figura 20. Classificació d'alguns blocs lògics pel color (esquerra); formació del conjunt de peces roges (dreta)

2. Diversos conjunts front a un conjunt. En classificar obtenim tantes classes d'equivalència com valors té la propietat general considerada en la relació. Per exemple, si classifiquem pel tipus de vehicle un conjunt de peces de plàstic de sis mitjans de transport diferents i sis colors, n'obtenim diversos conjunts, com es veu a la part esquerra de la figura 21. Quan formem el conjunt dels avions, sols s'obté un conjunt (figura 21, dreta).
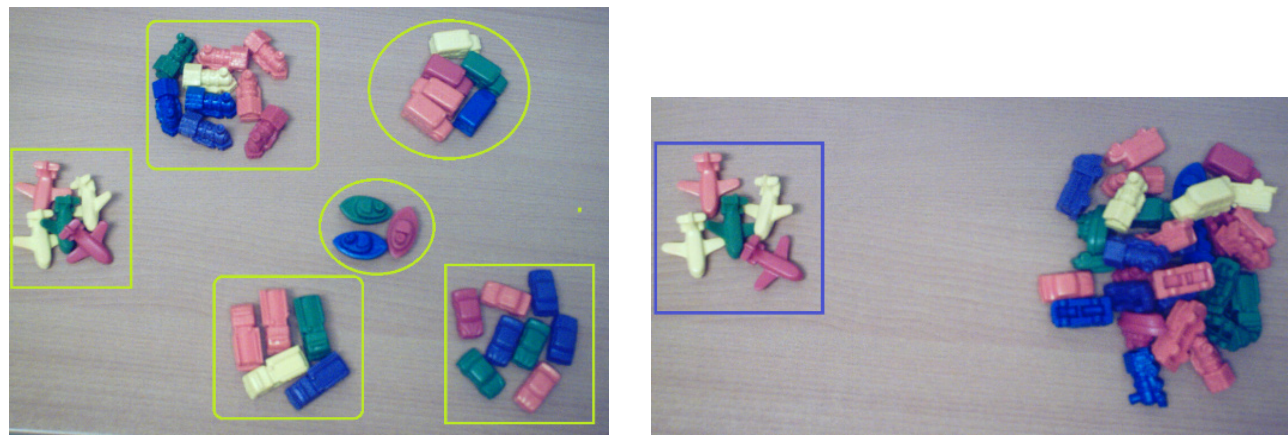

Figura 21. Classificació dels mitjans de transport pel tipus de vehicle (esquerra); formació del conjunt d'avions (dreta)

3. Tots els elements del conjunt referencial front a només uns quants. En una classificació tots els elements del conjunt referencial pertanyen a alguna de les classes, mentre que quan formem un conjunt sols alguns dels elements inicials s'agrupen per formar-lo, com es veu clarament en les figures 18 i 19.

En la realitat, els objectes, els animals, les persones, els fets, les malalties, les professions..., estan classificats, unes vegades per un criteri, d'altres per un altre, però classificats. És per això que cal estudiar aquest aspecte i estimular des d'educació infantil activitats relacionades amb ell, per tal d'enfrontar-se a la realitat amb un dels coneixements més necessaris per entendre-la.

El treball d'aquesta capacitat començarà al principi del segon cicle. Les primeres classificacions consistiran en la formació de parelles d'elements equivalents, uti- 
litzant pocs elements i obtenint, per tant, poques classes. És possible un exemple a partir d'una granja amb animals de plàstic entre els quals hi ha dues gallines, dues vaques i dos conills, han d'agrupar els animals que són del mateix tipus, obtenint així tres classes (tres parelles). Aquesta iniciació manté l'essència del que és una classificació: hi ha un conjunt referencial, formem classes i els elements queden distribuiits totalment. La dificultat de les activitats de formació de parelles ha de ser creixent durant el cicle, augmentant la quantitat d'elements en el conjunt referencial, la qual cosa provocarà un augment del nombre de parelles.

A més de la formació de parelles, també es treballaran les classificacions en les quals s'obtenen classes amb més de dos elements. Començarem utilitzant conjunts referencials amb pocs elements per obtenir poques classes amb cardinals menuts. Usant un exemple semblant a l'anterior i partint d'un conjunt de deu animals, agruparan tres ovelles, tres porcs i quatre cavalls. A mesura que avança el cicle augmentarem el nombre d'elements del conjunt referencial i, per tant, creixerà el nombre de classes que s'obtenen i els seus cardinals.

Caldrà acompanyar la formació de les classes amb la verbalització de les semblances entre els elements que pertanyen a cadascuna d'elles. Per exemple, en el cas anterior l'alumne verbalitzarà: «Ajunte aquests tres animals perquè són ovelles, aquests altres tres perquè són porcs...».

Com a complement d'aquest treball inicial de classificació i cap al final del cicle, podrem classificar de diverses maneres un mateix conjunt amb la finalitat d'observar les diferències entre el nombre de classes que obtenim en cada cas i entre els seus respectius cardinals. Si estem treballant amb un pot d'instruments d'escriptura, per exemple, podrem classificar-los pel tipus d'objecte, pel color, per si tenen o no tapadora, etc., i reflexionar amb els xiquets i les xiquetes sobre els diferents resultats que obtenim (el nombre de classes, el d'elements per classe...). Un exemple gràfic es mostra en la figura 22 , amb diferents classificacions d'un conjunt de peces dels blocs lògics. A la part esquerra s'ha classificat aquest conjunt en funció del color de les peces, obtenint tres classes d'equivalència; al centre, per la seua forma, obtenint-ne quatre i a la dreta s'observen dues classes segons la grossària de les peces. En aquestes activitats es torna a insistir en la necessitat que l'alumnat siga conscient de les diverses característiques que estan presents alhora en un mateix element.
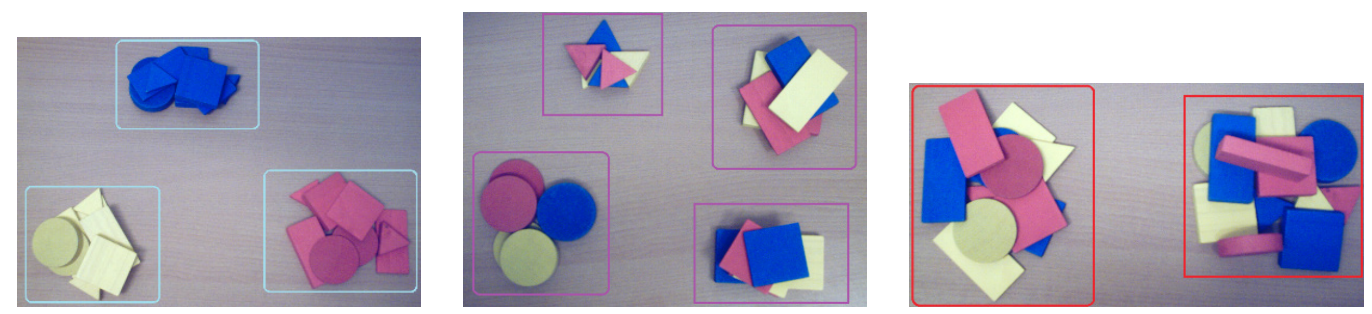

Figura 22. Classificacions d'algunes peces dels blocs lògics: segons el color (esquerra), la forma (centre) i la grossària (dreta) 
També en aquest moment poden fer classificacions amb elements evocats, és a dir, que no els tenen al davant físicament o en una imatge. Han de ser elements del seu entorn coneguts per ells i elles en els que puguen pensar fàcilment. Per exemple, poden classificar les persones de la seua família, uns contes que hi ha en la biblioteca de l'aula però que en eixe moment no tenen en les mans, els jocs que més els agraden, etc.

Cal tenir en compte que les propietats dels objectes que utilitzarem com a criteris per fer les classificacions hauran de ser molt clares, senzilles i ben conegudes per l'alumnat.

\section{Completar sèries d'elements en les quals vagen canviant les característiques del material segons un criteri donat}

El treball de completar sèries és molt diferent del que hem vist en les capacitats anteriors referent a la formació de conjunts o a les classificacions. Parlarem de sèries quan tinguem un conjunt d'elements ordenats d'una determinada manera, tenint en compte que aquest ordre es concreta en la repetició d'un grup inicial d'elements que ja estan ordenats i que anomenarem mòdul de la sèrie. El que es pretén és que l'alumnat repetisca aquest mòdul en l'ordre adequat fins a tenir-lo una quantitat de vegades determinada o fins que els elements s'esgoten.

Evidentment, per completar sèries necessitem que entre els elements amb els quals treballem hi haja alguns que siguen iguals en totes les seues característiques per poder repetir exactament el mòdul proposat les vegades que siga necessari.

Representarem en aquest text els diferents tipus de mòduls que utilitzem en les sèries mitjançant expressions numèriques en les quals cada nou dígit indicarà un canvi de propietats en els elements, el valor absolut dels nombres ens dirà quants elements iguals hi ha en el mòdul i la suma dels dígits serà el seu cardinal. Per exemple, si treballem les sèries amb fitxes de parxís podem proposar d'ordenar-les segons els mòduls següents:

- Mòdul de la sèrie: roig, groc, verd, blau (figura 23). Per abreujar en la redacció del text el representarem per 1111, indicant així que cap element es repeteix en el mòdul.

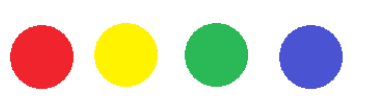

Figura 23. Representació del mòdul de quatre elements diferents d'una sèrie

- Mòdul de la sèrie: roig, roig, groc, verd, blau (figura 24). La representació abreujada serà ara 2111, on el 2 indica que hi ha dues fitxes juntes del mateix color. 


\section{$\bullet \bullet \bullet \bullet$}

Figura 24. Representació del mòdul de cinc elements d'una sèrie amb tres canvis de característica

- Mòdul de la sèrie: roig, verd, verd, blau, groc, groc (figura 25). La representació 1212 segueix el mateix patró que en els casos anteriors.

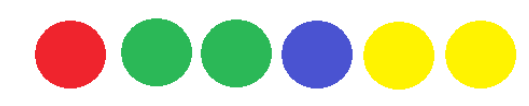

Figura 25. Representació del mòdul de sis elements d'una sèrie amb tres canvis de característica

Al principi del $2 \mathrm{n}$ cicle d'infantil iniciarem el treball de completar sèries el mòdul de les quals no tinga més de tres elements i on canvie una sola de les seues propietats. Per exemple, si enfilem boles de fusta per fer un collar i volem que els xiquets i les xiquetes repetisquen una blanca i una negra o una groga, una blava i una roja, estarem treballant amb una sèrie de mòdul 11 o de mòdul 111, respectivament.

En els primers passos d'aquestes activitats convé proporcionar-los un model que continga dues vegades el mòdul perquè puguen observar la repetició i descobrir quin és realment el mòdul de la sèrie. En l'exemple anterior els oferirem una groga, una blava, una roja i de nou una groga, una blava, una roja i l'alumnat haurà de repetir a continuació altres grups de tres boles dels mateixos colors en el mateix ordre (figura 26). Si enfilàrem una bola verda, una roja i una altra roja, el mòdul que haurien de repetir seria en aquest cas del tipus 12 i es tractaria d'una sèrie de més dificultat que l'anterior.

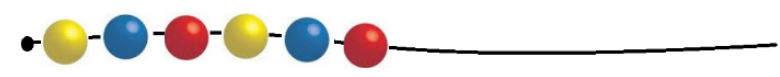

Figura 26. Representació de dos mòduls, de tres elements diferents per una característica, d'una sèrie

Una vegada introduït el concepte de mòdul de la sèrie, no serà necessari mostrar-lo a l'alumnat més d'una vegada perquè puguen continuar la sèrie.

Més endavant es pot augmentar el mòdul de la sèrie i aquest podrà estar constituït per fins a 5 elements que s'agruparan d'un en un o en dos petits grups de més d'un element. Per exemple, si volem decorar la classe pintant els ninots d'una sanefa de diferents colors, podem pintar un ninot verd, un roig, un blau, un groc i un taronja (mòdul 11111) o dos rojos i tres blaus (mòdul 23, com es mostra en la figura 27) o un verd i tres grocs (mòdul 13), etc., perquè els xiquets i les xiquetes continuen acolorint els ninots següents respectant aquest ordre. 


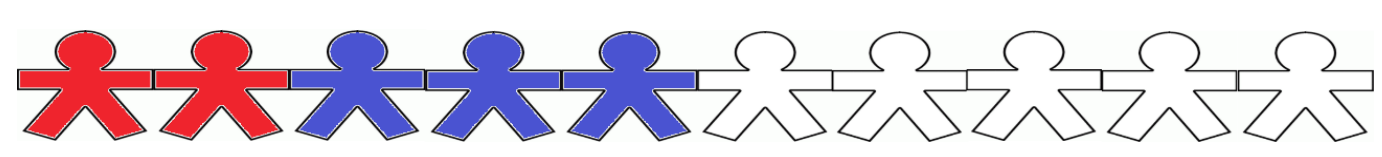

Figura 27. Representació dels cinc elements del mòdul d'una sèrie amb un canvi d'una característica

En la segona meitat del cicle cal ampliar el treball manipulatiu de les sèries amb la utilització de mòduls que es presentaran a l'alumnat mitjançant representacions gràfiques. Al principi amb gomets de diferents formes, colors, grandàries, etc., $\mathrm{o}$ amb objectes dibuixats que acoloriran (figura 27), per passar posteriorment a què els xiquets i les xiquetes copien i pinten els diferents elements que composen la sèrie. També es podria fer utilitzant materials didàctics estructurats adients a la formació de sèries gràfiques (figura 28).

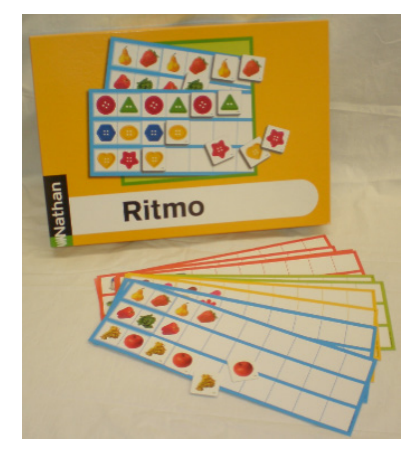

Figura 28. Ritmo (fabricat per Nathan)

Cap al final del cicle el mòdul pot arribar a estar constituït per fins a 9 elements que podran agrupar-se d'un en un o en diversos grups de més d'un element. Així, tornant al collar, podrem tenir mòduls 111111111 (una bola de cada color), 34 (tres boles blaves i quatre grogues), 1232 (una bola groga, dues blaves, tres roges i dues verdes, com es veu en la figura 29), 223 (dues boles grogues, dues blaves, tres roges), etc.

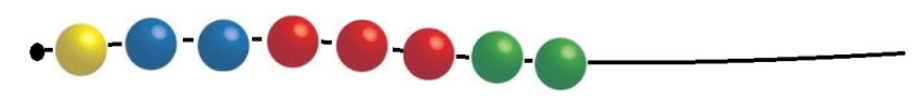

Figura 29. Representació d'un mòdul de vuit elements d'una sèrie amb tres canvis d'una característica

També podem augmentar la dificultat de les sèries ordenant els elements d'acord amb la variació de més d'una de les seues propietats, tenint cura que en aquests casos els mòduls no tinguen molts elements. Per exemple, en el collar podem utilitzar boles de grandàries diferents i col·locar una bola roja gran, una blava petita i una verda mitjana (mòdul 111, figura 30) o dues roges grans i tres blaves petites (mòdul 23, figura 31). En el cas de les representacions gràfiques podem treballar també amb series en les quals canvie més d'una propietat. 


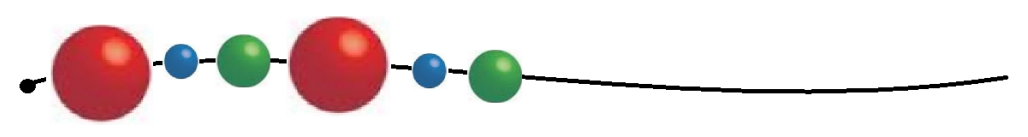

Figura 30. Representació d'un mòdul de tres elements d'una sèrie amb dos canvis de dues característiques

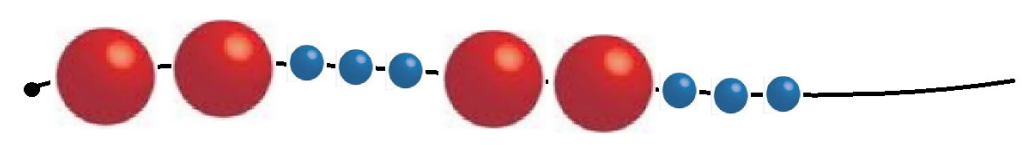

Figura 31. Representació d'un mòdul de cinc elements d'una sèrie amb un canvi de dues característiques

El nivell fins al qual es pot arribar al llarg de l'etapa en la dificultat de la tasca de completar sèries depén molt de les possibilitats de l'alumnat. Si fóra possible, seria convenient ampliar-lo a sèries més complexes que les esmentades, bé perquè els mòduls tinguen més elements o bé perquè canvien més propietats dels elements alhora. A més, també s'intentarà fer aquest treball a partir de sèries inventades pels mateixos infants.

\section{Ordenar elements segons els matisos d'una de les seues qualitats}

Quan es classifica, el que es fa és organitzar la realitat en funció de les semblances que tenen els objectes. En aquestes activitats, l'important és la similitud de les característiques. Però, de vegades, no ens interessen les semblances, sinó els diferents matisos que presenten els objectes respecte d'alguna de les seues qualitats. La grandària, per exemple. Si volem ordenar caixes per aquesta característica ens fixarem en les diferents grandàries que trobem i en funció d'aquestes diferències les ordenarem.

Treballarem a partir de situacions quotidianes per tal d'establir les ordenacions, no és necessari forçar activitats d'ordre perquè perdrien tot el seu interés inicial.

Relacionat amb situacions que es presenten a l'aula començaran ordenant objectes quotidians per grandàries i per longituds aprofitant el coneixement de gran, mitjà, menut, llarg i curt treballat en la capacitat 1.2. Quan s'hagen realitzat aquestes primeres ordenacions podem treballar utilitzant referències d'altura, amplària, grossària, $\mathrm{i}$ ordenant en principi només tres elements. Usant el vocabulari que s'ha introduït a la capacitat 1 , expressaran la relació d'ordre que establim entre els elements. Per exemple, en l'ordenació creixent d'unes caixes per les seues grandàries, els xiquets i les xiquetes verbalitzaran: «Aquesta caixa és més petita que la següent, que és més petita que...».

Més tard, ampliarem la quantitat d'elements fins a 5 i els ordenarem també a partir d'altres característiques que puguen tenir: temperatura, grau d'humitat... 
Cap al final del cicle repassarem tot allò treballat anteriorment i ampliarem la dificultat amb l'augment del nombre d'elements a ordenar i utilitzant altres criteris més complicats (tonalitats de color, escales de sons...).

Al llarg de tot el cicle es pot completar el treball manipulatiu que han fet amb objectes de l'entorn, amb la utilització de materials didàctics específics (figura 32).
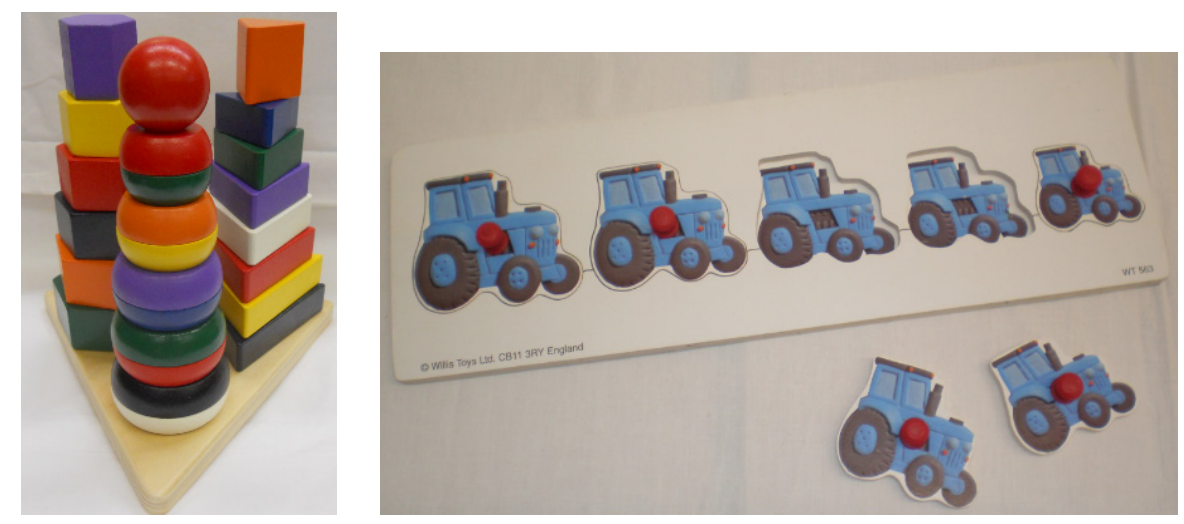

Figura 32. Pyramide 3 en 1, fabricat per Small Foot Company (esquerra) i Decreixent Tractors, fabricat per Willis Toys Ltd (dreta)

\section{Establir correspondències qualitatives entre els elements de dos conjunts}

Les correspondències són la manera d'exposar matemàticament les associacions que s'estableixen entre els elements de dos conjunts.

En aquesta capacitat es treballaran situacions reals on apareguen correspondències unívoques i biunívoques i aplicacions bijectives i no bijectives (vegeu 2.3 d'aquest tema), perquè l'alumnat puga observar diferents maneres d'associar uns elements amb altres. Evidentment, el nom d'aquests tipus de correspondències i aplicacions no s'introduirà a l'aula.

Al principi del cicle cal aprofitar les correspondències habituals que es troben en el seu medi, per exemple: cada alumne s'associa amb el seu nom i cognoms (segurament serà una aplicació bijectiva); cada alumne/a s'associa amb la seua foto per saber el lloc on penjar la jaqueta (bijectiva); cada alumne/a s'associa amb el seu lloc per seure (bijectiva, si no queden cadires buides); cada alumne/a s'associa amb el seu grup de treball (no bijectiva, però sí aplicació); cada taula col·lectiva de l'aula amb el grup de treball que l'ocupa (bijectiva, si no queda cap taula buida) (figura 33); cada racó de l'aula amb les activitats que es poden desenvolupar en ell (correspondència).... 


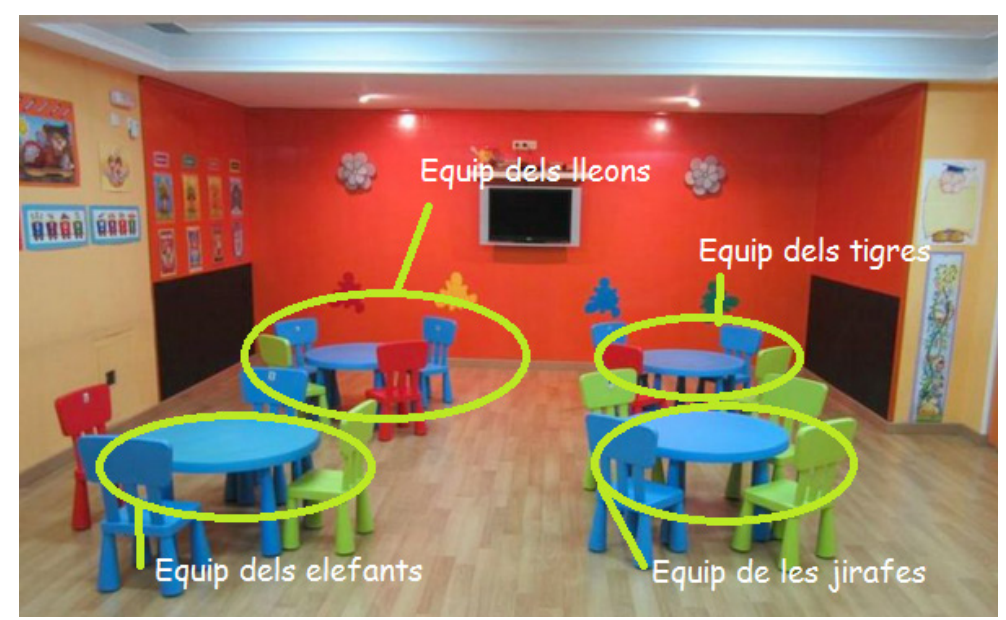

Figura 33. Representació d'una correspondència entre taules col·lectives i grups de treball

També es poden treballar les correspondències que intervenen en jocs d'associació de sons amb moviments o accions. Per exemple, els xiquets i les xiquetes caminen per dins de l'aula $\mathrm{i}$ han d'acomplir les indicacions següents: quan el docent fa una palmada, s'ajupeixen; quan fa sonar un xiulet, fan un salt; quan toca el tabal, s'aturen... En aquests casos es poden donar correctament les instruccions mitjançant una aplicació bijectiva, com la de l'exemple, o es pot modificar l'actuació de la mestra per fer que aparega algun so que no tinga cap moviment associat, és a dir, sona una flauta sense que tinguen una pauta per a aquest so, per exemple. En aquest moment estem treballant amb una correspondència biunívoca.

Totes aquestes activitats van creant estructures mentals que possibiliten la connexió amb altres pensaments posteriors més complicats, que són la base de futurs conceptes matemàtics (funció cardinal i ordinal del nombre, per exemple).

També cal treballar correspondències per criteris d'ús, com la següent: en un conjunt tindríem xiquets $\mathrm{i}$ xiquetes disfressats de bomber, metge, cuiner, jardiner $\mathrm{i}$ policia, i a sobre d'una taula posaríem una xeringa, un fonendoscopi, una mànega de bomber, una escala, un perol, un barret de cuiner, un arruixador, un rastell. Cada xiquet i xiqueta hauria d'agafar els utensilis que corresponen a la seua professió, amb el que aconseguiríem una correspondència no unívoca.

Es poden ampliar aquestes activitats amb correspondències per criteris d'associació de qualitats iguals. Per exemple, disposem d'una caixa de globus i d'una altra de cintes. L'alumnat deu associar cada globus amb una cinta del mateix color que ell per lligar-lo.

En la segona meitat del cicle, cal plantejar jocs de transformació en els quals han de construir una figura bé amb peces reals, bé amb gomets de diferents formes o altres materials, que reproduïsca una altra ja construïda, aplicant un canvi a alguna de les característiques de les peces que composen la figura inicial. Per exemple, construïm una caseta amb peces blaves dels blocs lògics i els demanen que construïsquen una altra caseta del mateix format però amb peces roges (figura 34). 

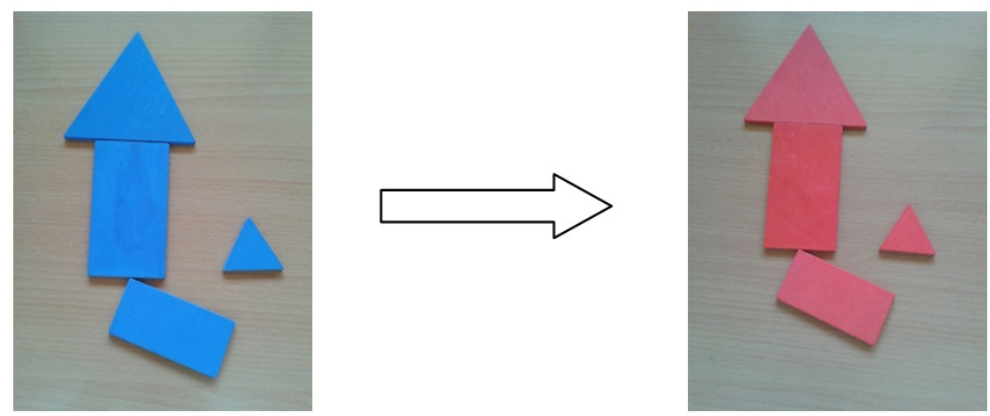

Figura 34. Representació d'una correspondència de transformació amb blocs lògics

Cap al final del cicle es provaran criteris més complexos per tal d'associar els elements de diferents conjunts i es completarà el treball amb representacions gràfiques de correspondències.

En tots els casos l'alumnat verbalitzarà els criteris d'associació que defineixen les correspondències que establim (nugue aquest globus blau amb la cinta blava, per exemple).

\section{Representar gràficament relacions $i$ associacions d'elements}

Aquesta capacitat complementa el treball desenvolupat en les quatre darreres, incorporant representacions gràfiques dels diferents conceptes estudiats, a mesura que les possibilitats dels xiquets $\mathrm{i}$ les xiquetes ho permetan. Cal ser conscients de l'evolució de la seua motricitat fina i serà, per tant, un element més a considerar, però no l'únic, per tal de saber si estan fent correctament el que es demana.

Quan es tracta de representar una classificació en un full amb elements dibuixats, poden pintar d'un mateix color aquells que pertanyen a la mateixa classe, o envoltar-los amb un diagrama com es veu en la figura 35, on s'han classificat alguns animals de la granja pel criteri «ser animals iguals».

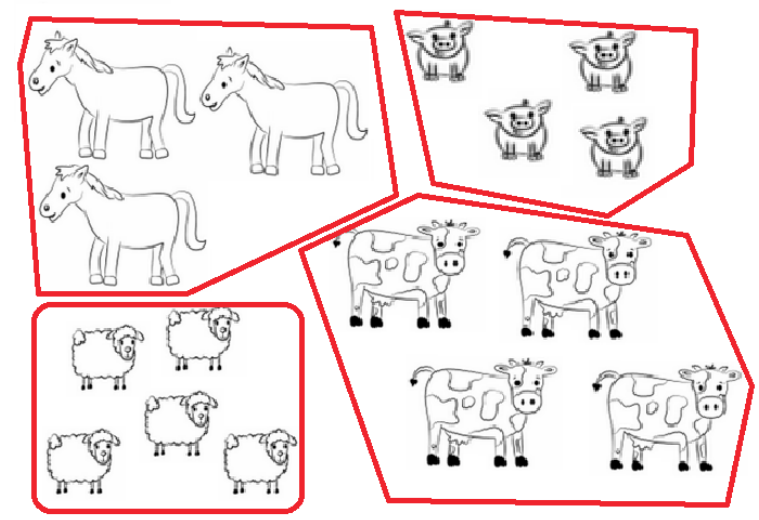

Figura 35. Representació d'una classificació amb diagrames

El treball gràfic amb sèries s'ha comentat ja en la capacitat corresponent. 
Si es tracta de representar una ordenació, podem treballar de tres maneres diferents. En primer lloc, poden retallar els dibuixos i ordenar-los. Més endavant utilitzaran una línia (o fletxa) per a unir l'element primer de l'ordenació (el més gran, per exemple) amb el que el segueix i cadascú amb el posterior de la mateixa manera. Per últim, i depenent del moment en què ens trobem en el treball amb les grafies i l'ordenació dels nombres, es poden numerar els elements indicant el seu ordre mitjançant el que segueixen els nombres naturals (figura 36).
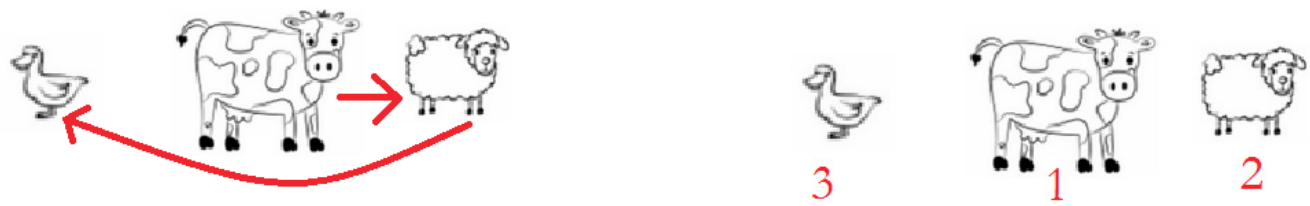

Figura 36. Representació d'una ordenació de gran a menut amb fletxes (esquerra) i nombres (dreta)

Seran les fletxes les encarregades de representar gràficament les associacions entre els elements de dos conjunts quan entre aquests s'haja establert qualsevol tipus de correspondència. En la figura 37 es mostra un exemple en què, tornant a treballar amb les imatges dels animals de la granja, se n'ha definit una que associa els animals iguals.

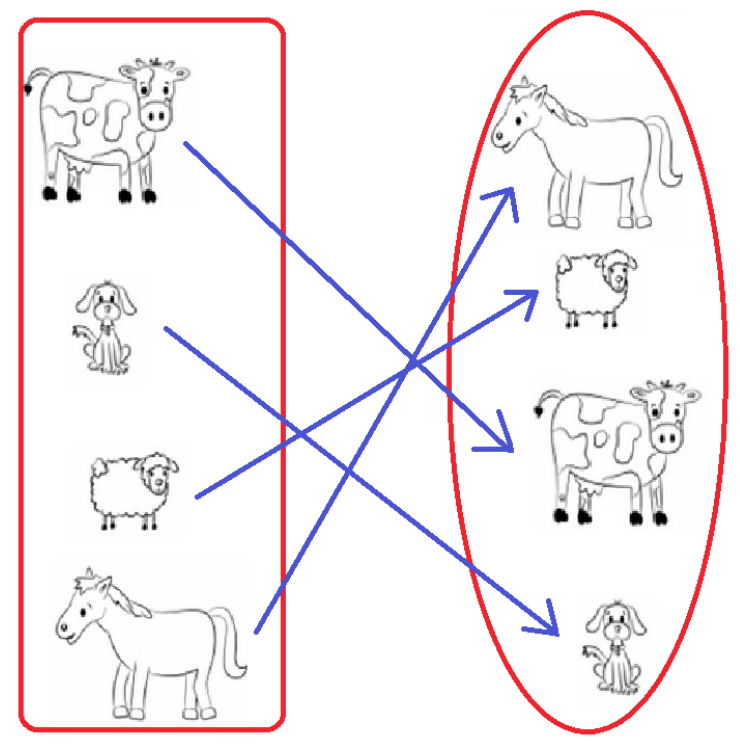

Figura 37. Representació d'una correspondència que associa parelles d'animals iguals 


\section{TEMA 2}

\section{Els nombres naturals en l'educació infantil}

\section{Introducció}

En aquest tema es treballa la construcció del concepte de nombre natural a partir de la Teoria de Conjunts, per oferir als mestres d'educació infantil les ferramentes necessàries per a introduir aquest concepte als xiquets i les xiquetes, proporcionant-los així els recursos matemàtics que els ajuden a respondre les preguntes que la realitat els planteja respecte a «quants n'hi ha?» en diferents situacions.

Comença amb una reflexió sobre el concepte de nombre natural, continua amb una formalització del conjunt que formen aquests nombres i dels sistemes de numeració, incloent una aproximació històrica, per finalitzar amb un extens tractament didàctic de com introduir els primers nombres naturals a l'aula d'infantil.

\subsection{Reflexió sobre el concepte de nombre natural}

Si la pregunta que ens feren fos si sabem què és un nombre, tothom podria afirmar que, efectivament, sap què és un nombre. Si més no, també ens podríem atrevir a explicar-ho, però a l'hora de definir-ho clarament comencen les dificultats.

Hi ha moltes definicions que s'aproximen el concepte de nombre, però cap d'aquestes és totalment independent:

- Entitat abstracta que representa una quantitat específica.

- Símbols que s'utilitzen per a representar els nombres: numerals.

- Elements que formen els sistemes numèrics.

El concepte de nombre varia en les persones, segons l'edat i la formació que tenen. Per als xiquets i les xiquetes els nombres indiquen quantitats o ubicacions (cardinal i ordinal), o també els símbols per a representar-les.

Tornant a la pregunta què és un nombre?, trobaríem possibles respostes, per exemple a la pregunta, què és el nombre $u$ ?, podrien aparèixer: $0,1, u$, so del nom del nombre. 
Analitzem-les:

- ○ referent intuïtiu, una marca, un símbol, un punt... indicarà una unitat, una sola cosa. Per a representar el dos, caldrien dos símbols com aquest:

- 1 , signe o guarisme que en la nostra societat indica una unitat, una sola cosa. Amb aquest signe se simbolitzen quantitats, s'opera... L'única intuïció és que és un únic símbol per a l'u; però el 2, també és un símbol únic, mentre que la quantitat és dos (que correspon a un conjunt que té un element $i$ un altre element); el mateix passaria amb 3... Aleshores, és una representació abstracta.

- $u$, nom escrit que en la nostra llengua indica una unitat, una sola cosa. Amb aquesta es parla, s'escriu o es llig. No s'opera. No és intuïtiu a priori, perquè segons l'idioma s'escriu amb una o diverses lletres (en català $u$ o un, una o dues lletres; en castellà un o uno, dues o tres lletres; en anglès one, també tres lletres...).

- so del nom del nombre, s'ha d'identificar una paraula concreta amb una quantitat, i aquest so també és diferent segons l'idioma amb el qual es parle.

Al llarg del 2n cicle d'educació infantil (3-6 anys), els nens i les nenes utilitzen processos propis d'identificació de la quantitat. Al principi potser no saben què representa un nombre ni com és la xifra que el correspon, però saben si tenen més o menys objectes per a jugar que el company o la companya, perquè la idea de quantitat és intuïtiva.

Per tant, quin és el procés d'introducció dels nombres? Com en molts altres moments de l'ensenyament, aquest és un procés en espiral, al qual es pot accedir des de distints punts. La nostra societat està envoltada de xifres, de nombres, de paraules que signifiquen nombres i quan parlem utilitzem els nombres indiscriminadament. Per tant, en el mateix aprenentatge natural de l'alumnat, apareixen nombres. En l'escola, es començarà per allò que és més intuïtiu, com ara agrupacions d'elements que indiquen la quantitat, a la que s'anirà associant a poc a poc els noms dels nombres. L'u comptabilitzarà un objecte, el dos, dos objectes i així, successivament. Més endavant s'introduiran les xifres, la seua grafia, i, en una fase posterior, els noms escrits.

En el 2n cicle d'educació infantil s'introdueix de l'1 al 9. A més del contacte amb els nombres que l'alumnat tindrà a partir de les seues experiències en la realitat, es poden utilitzar alguns materials didàctics com els que es mostren a continuació, per tal d'ajudar els xiquets $i$ les xiquetes a construir aquests nombres i dominar el seu ús i significat.

El material Anelles de colors consta d'una base de fusta amb uns pilars fixos de diferents alçades, d'anelles de colors que s'han de col·locar en els pilars i d'unes fitxes quadrades on apareixen els nombres representats per quantitats de cercles en uns casos i per xifres en uns altres (figura 38). 


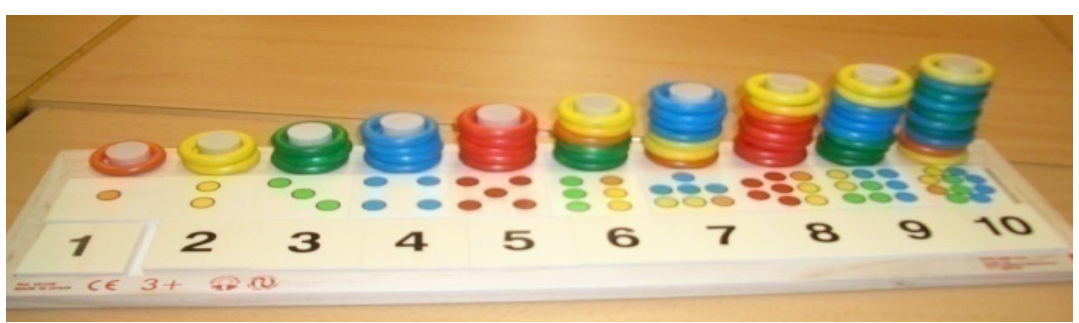

Figura 38. Anelles de colors (fabricat per Goula)

Segons el moment en el qual es trobe l'alumnat, podrem utilitzar només els cercles, els cercles i les xifres o sols les xifres per associar-los amb les anelles (figura 39).
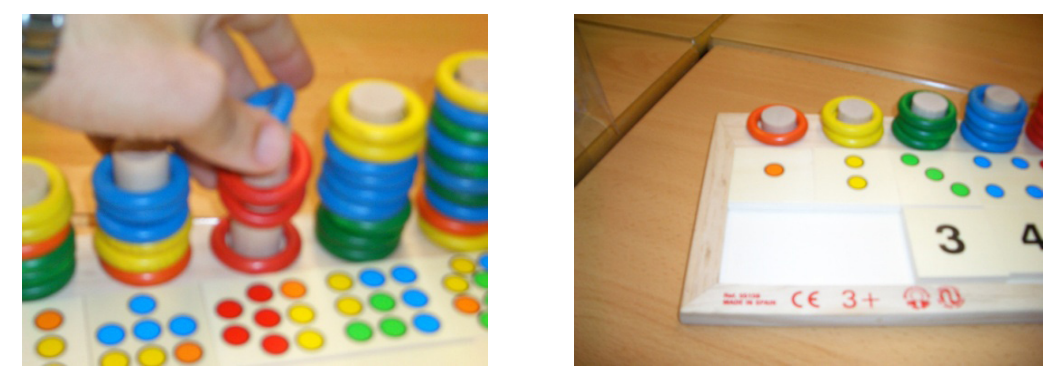

Figura 39. Ús d'anelles de colors sols amb punts (esquerra) i amb punts i xifres (dreta)

És molt intuïtiu i no necessita massa motricidad fina. Per contra, no duu els noms dels nombres escrits i, com que els pilars són fixos i la seua alçada és la que correspon a la quantitat d'anelles que cal posar, els xiquets i les xiquetes poden omplir-los amb anelles sense reflexionar molt si és o no el nombre correcte d'unitats. Si volem comprovar que coneixen bé els nombres, podem alterar la posició de les fitxes quadrades associant-les amb pilars que no els corresponen i observar si són capaços d'arreplegar la quantitat adequada d'anelles.

Un altre material, anomenat Aprenc a comptar, està format per fitxes de plàstic de dos colors que tenen impresa la grafia o el nom dels nombres de l'1 al 10, varetes de plàstic de deu longituds diferents adaptades a les quantitats i boles de colors que s'enfilen en cadascuna d'elles. En aquest material, totes les peces estan soltes i es pot muntar com un trencaclosques (figura 40).

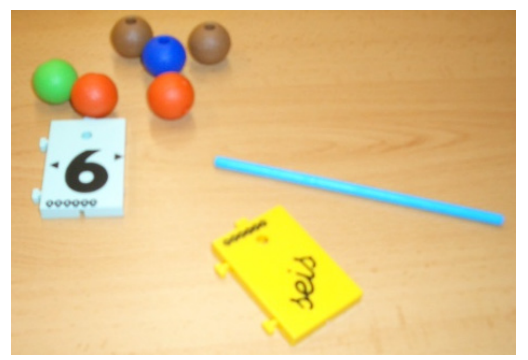

Figura 40. Peces del material Aprenc a comptar (fabricat per Lado)

Per a utilitzar-lo cal tenir una certa motricitat fina, perquè totes les peces han de ser col·locades al seu lloc i el forat de les boles no és gaire gran (això no passa en 
el joc Anelles de colors). Segons el moment evolutiu de l'alumnat, podem usar els noms escrits del nombres o no.

En la figura 41 es mostra una seqüència gràfica de la construcció del nombre 6 i de la introducció de la seua grafia i del seu nom escrit.
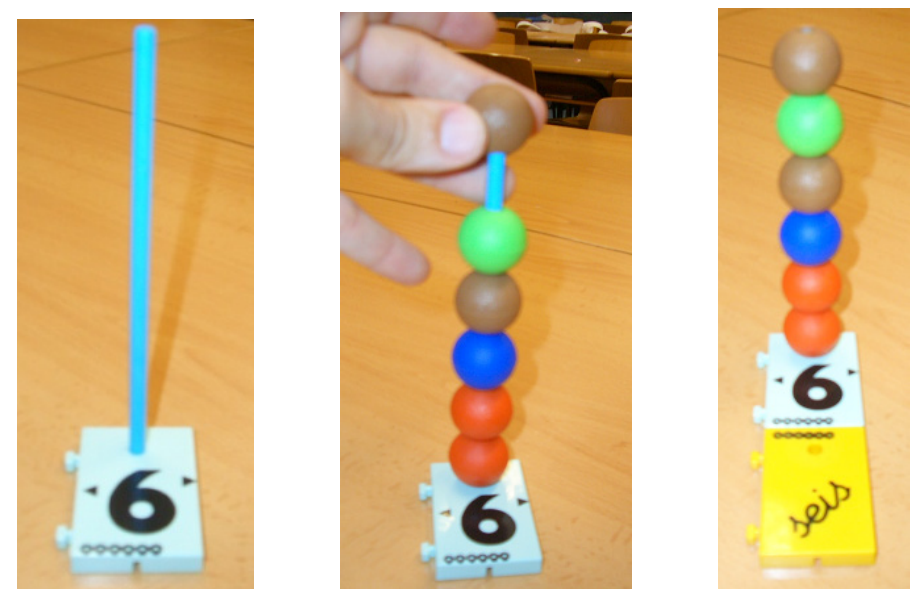

Figura 41. Seqüència de la construcció del nombre 6 (d'esquerra a dreta)

Al principi, cada vareta s'associarà, segons la seua altura, amb el nombre corresponent. Més endavant podem associar cada vareta amb diferents nombres per a comprovar si els coneixen realment (figura 42) i assignen adequadament la quantitat de boles.
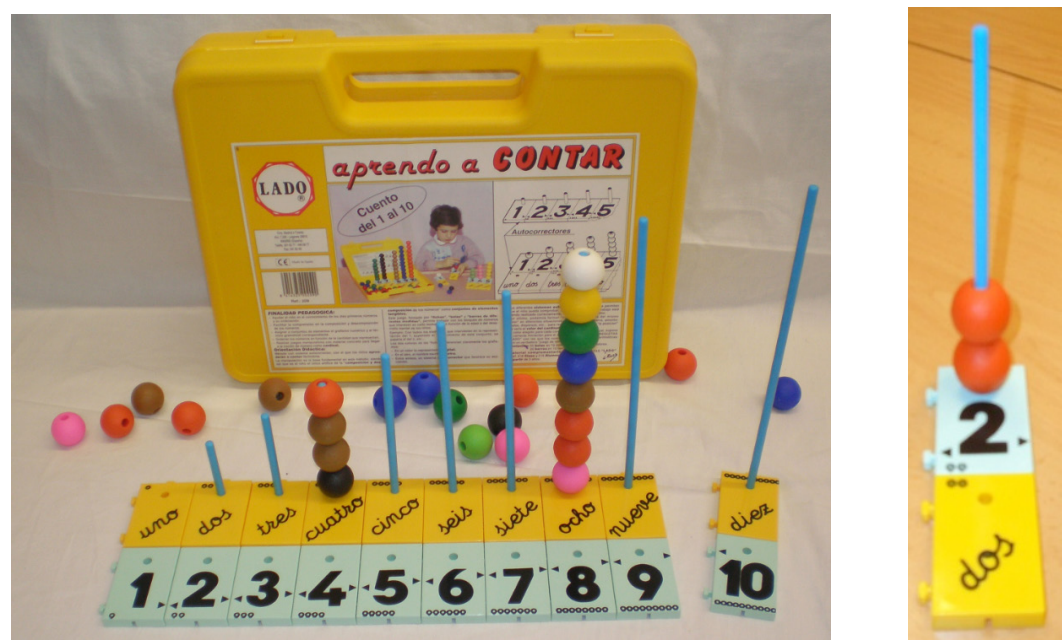

Figura 42. Varetes associades als nombres per la seua altura (esquerra) i ús de la vareta del 6 amb peces del 2 (dreta) 


\subsection{Contextos i usos del nombre natural}

El conjunt dels nombres naturals es denota com $\mathbb{N}: \mathbf{0 , 1}, \mathbf{2}, \mathbf{3} \ldots$, i els utilitzem:

- Per a comptar: 5 xiquets i xiquetes en un grup de treball, 3 personatges en un conte...

- Per a ordenar: la 1a planta de l'escola, el 3r alumne que arriba a classe...

- Per a mesurar: $84 \mathrm{~cm}$ d'alçada, el gerro conté 4 gots de suc...

- Per a operar: 3 nens i 4 nenes fan 7 alumnes, em menge 2 galetes de 5 i en queden $3 \ldots$

- Per a identificar o codificar: el telèfon de l'us és 964728 000, l'aula 1117...

Hi ha funcions que l'alumnat ja té integrades abans de saber comptar, perquè són intuïtives. Aquestes funcions (Gallego et al., 2005) i el treball que realitzarem amb objectes de l'entorn ens permetran aconseguir que els xiquets i les xiquetes arriben a considerar el nombre natural com a cardinal i com a ordinal. Cardinal en el sentit de comptar una quantitat d'objectes i ordinal en el sentit d'ordenar-los.

La definició actual de nombre que inclou aquests dos aspectes es basa en la intuïció i està relacionada íntimament amb el concepte de conjunt i quantitat d'elements d'un conjunt. Aquesta formalització de la idea de nombre no ha estat present sempre al llarg de la història i no apareix fins al segle XIX quan G. Cantor defineix formalment els conjunts numèrics, el primer dels quals és el dels nombres naturals. Hi ha altres definicions, com l'axiomàtica de Peano, però ens centrarem en la de Cantor per estar més a prop de la ment de l'alumnat escolar.

\section{Formalització del conjunt dels nombres naturals}

Com a pas previ al treball didàctic en la formació dels docents i per tal de fonamentar-lo, considerem necessari incloure les bases formals de la construcció del conjunt dels nombres naturals, perquè estiguen a l'abast de qualsevol lector que les vulga consultar. Òbviament, aquest tractament formal de la construcció dels nombres no s'ha de realitzar a l'aula d'infantil.

\subsection{Definició de nombre natural}

En el tema 1 «Desenvolupament dels conceptes lògics» hem parlat del concepte de conjunt i d'altres associats a ell com els següents: element, cardinal, operacions entre conjunts, correspondències i aplicacions, relacions binàries, etc.

A partir d'ells i considerant un conjunt $\mathbf{X}$ format per tots el conjunts finits existents, definim la següent relació binària entre els seus elements: si $\mathbf{A}$ i $\mathbf{B}$ són dos 
conjunts finits arbitraris que pertanyen a $\mathbf{X}$, direm que són coordinables, equipotents o equipol·lents $(\boldsymbol{A} R \boldsymbol{B})$ sii existeix una aplicació bijectiva entre ells.

Aquesta és una relació binària d'equivalència perquè acompleix les propietats següents:

- Propietat reflexiva. Entre un conjunt i ell mateix sempre existeix la identitat com a aplicació bijectiva $(\boldsymbol{A} R \boldsymbol{A})$.

- Propietat simètrica. Si entre els conjunts $\mathbf{A}$ i $\mathbf{B}$ es defineix una aplicació bijectiva $\mathbf{f}$, la seua inversa $\mathbf{f}^{-1}$ és una aplicació bijectiva entre $\mathbf{B}$ i $\mathbf{A}(\mathbf{A} R \mathbf{B} \rightarrow$ B $R \mathbf{A})$.

- Propietat transitiva. Si entre els conjunts A i B es defineix una aplicació bijectiva $\mathbf{f}$, i al mateix temps entre els conjunts $\mathbf{B}$ i $\mathbf{C}$ es defineix una altra bijecció $\mathbf{g}$, entre els conjunts $\mathbf{A}$ i $\mathbf{C}$ queda també definida una bijecció per la composició de les aplicacions $\mathbf{f}$ i $\mathbf{g}$ anteriors $(\mathbf{A} R \mathbf{B}$ i $\mathbf{B} R \mathbf{C} \rightarrow \mathbf{A} R \mathbf{C})$.

Per ser d'equivalència origina una classificació dels elements de $\mathbf{X}$. Aleshores definim nombre natural com «la propietat comú de tots els conjunts finits d'una classe d'equivalència determinada per aquesta relació d'equipotència».

Però, com es pot concretar eixa propietat comú?

L'existència d'una aplicació bijectiva entre A i B ens indica que cada element del conjunt inicial (A) rep en el conjunt final (B) una imatge o element amb el qual es correspon de manera única, i cada element del conjunt final s'associa també de manera única amb un element del conjunt inicial, com es veu en l'exemple de la figura 43.

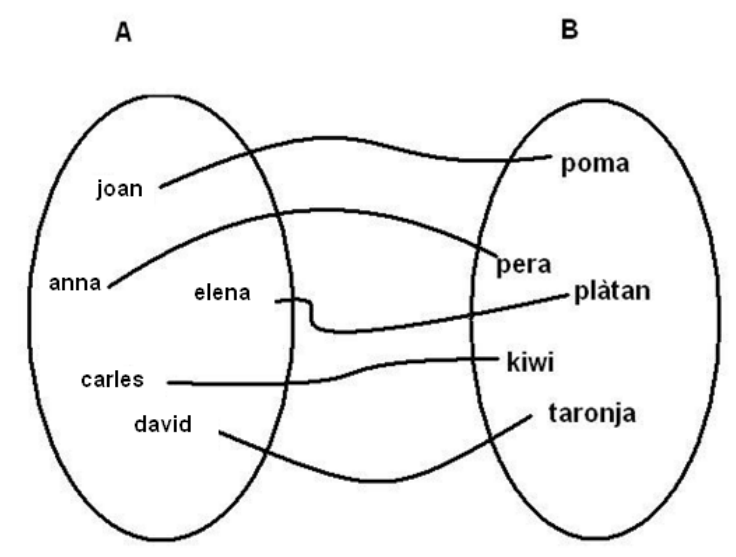

Figura 43. Representació d'una aplicació bijectiva entre dos conjunts finits

Aquesta associació un a un dels elements dels dos conjunts ens assegura que els conjunts equipotents, coordinables o equipol·lents, per ser bijectius entre sí, tenen el mateix cardinal i, per tant, serà el cardinal comú la propietat que estàvem concretant i que caracteritza a tots els conjunts finits d'una mateixa classe d'equivalència. 
Així, el nombre zero representa a la classe d'equivalència del conjunt buit, el nombre u a la classe d'equivalència dels conjunts equipotents, per exemple, al conjunt $\mathrm{A}=\{\mathrm{el} \mathrm{Sol}\}$ (si ens permetem usar $u$ o $u n$ en la definició d'u, es pot redactar: el nombre $u$ representa a la classe d'equivalència dels conjunts amb un element), el dos representaria tots els conjunts equipotents, per exemple, al conjunt $\mathrm{A}=\{$ la Terra, la Lluna\} (si acceptem usar dos en la definició del dos, es pot redactar: el nombre dos representa a la classe d'equivalència dels conjunts amb dos elements), etc. En general, un conjunt $\boldsymbol{A}$ pertany a la classe del nombre natural $\boldsymbol{m}$ si $\operatorname{card}(\boldsymbol{A})=\boldsymbol{m}$.

Una vegada queda clar que tots els conjunts equipotents, coordinables o equipollents tenen el mateix cardinal, amb un que utilitzem per a representar-los a tots ens bastaria. És a dir, tots els conjunts amb 5 elements contenen la mateixa informació pel que fa al cardinal; per tant, amb un conjunt que els represente n'hi ha prou. Ocorre el mateix per a tots els nombres naturals i, per tant, amb un sol conjunt finit podem representar qualsevol d'aquests nombres.

\subsection{Operacions en $\mathrm{N}$}

Siguen a i b dos nombres naturals i $\boldsymbol{A}$ i $\boldsymbol{B}$ dos conjunts finits, arbitraris i disjunts, de manera que $\mathbf{a}=\operatorname{card}(\boldsymbol{A})$ i $\mathbf{b}=\operatorname{card}(\boldsymbol{B})$. Es defineix l'addició de $\mathbf{a}$ i $\mathbf{b}$, com el cardinal de la unió de A i $\boldsymbol{B}$. És a dir:

$$
\forall a, b \in N \wedge \forall A, B \in X / a=\operatorname{card}(A), b=\operatorname{card}(B) \wedge A \cap B=\Phi: a+b=\operatorname{card}(A \cup B)
$$

A partir de les propietats de les operacions entre conjunts es pot demostrar que l'addició de nombres naturals acompleix les propietats commutativa i associativa.

Siguen a i b dos nombres naturals i $\boldsymbol{A}$ i $\boldsymbol{B}$ dos conjunts finits, arbitraris, de manera que $\mathbf{a}=\operatorname{card}(\boldsymbol{A})$ i $\mathbf{b}=\operatorname{card}(\boldsymbol{B})$. Es defineix la multiplicació de $\mathbf{a} \mathbf{i} \mathbf{b}$, com el cardinal del producte cartesià de $\mathbf{A} \mathbf{i} \boldsymbol{B}$. És a dir:

$$
\forall a, b \in N \wedge \forall A, B \in X / a=\operatorname{card}(A), b=\operatorname{card}(B): a \times b=\operatorname{card}(A \times B) .
$$

A partir de les propietats de les operacions entre conjunts es pot demostrar que la multiplicació de nombres naturals acompleix la propietat commutativa, associativa i distributiva respecte de l'addició.

\subsection{Ordre en $\mathrm{N}$}

Si en aquest conjunt definim la relació «ser menor o igual» de la següent manera:

$$
\forall a, b \in N: a \leq b \leftrightarrow \exists n \in N / a+n=b
$$

es pot comprovar que és una relació binària d'ordre total perquè acompleix les propietats següents: 
- Propietat reflexiva. Qualsevol nombre natural sempre és menor o igual que ell mateix, perquè $\exists 0 \in N / a+0=a(a \leq a)$

- Propietat antisimètrica. Si un nombre natural és menor o igual que un altre $\mathrm{i}$ a la vegada el segon és menor o igual que el primer, necessàriament ambdós nombres són iguals. És a dir,

$$
\begin{aligned}
& \forall a, b \in N / a \leq b \wedge b \leq a \rightarrow \exists n \in N / a+n=b \wedge \exists m \in N / b+m=a \rightarrow \\
& (b+m)+n=b \rightarrow m+n=0 \rightarrow m=0=n \rightarrow a=b(a \leq b \wedge b \leq a \rightarrow a=b)
\end{aligned}
$$

- Propietat transitiva. Si un nombre natural és menor o igual que un altre i a la vegada aquest és menor o igual que un tercer, aleshores el primer és menor o igual que el tercer. És a dir:

$$
\begin{aligned}
& \forall a, b, c \in N / a \leq b \wedge b \leq c \rightarrow \exists n \in N / a+n=b \wedge \exists m \in N / b+m=c \rightarrow \\
& (a+n)+m=c \rightarrow a+(n+m)=c \rightarrow a \leq c(a \leq b \wedge b \leq c \rightarrow a \leq c)
\end{aligned}
$$

- Propietat connexa. Donats dos nombres naturals qualssevol, o el primer és menor o igual que el segon o el segon és menor o igual que el primer. És a dir, $\forall a, b \in N: a \leq b \vee b \leq a$. Per a demostrar aquesta propietat haurem de contemplar dos casos:

1. Si $\boldsymbol{a}=\boldsymbol{b}$, és evident que $a \leq b \vee b \leq a$

2. Si $\boldsymbol{a} \neq \boldsymbol{b}$, existirà sempre un altre nombre natural que sumat a un d'aquests donarà com a resultat l'altre, és a dir:

$$
\exists n \in N / a+n=b \vee b+n=a \rightarrow a \leq b \vee b \leq a
$$

Direm aleshores que $\mathbb{N}$, amb la relació anterior, és un conjunt totalment ordenat i no hi haurà cap dubte a l'hora d'establir si un nombre natural és major, menor 0 igual que un altre.

Encara que hem definit la relació d'ordre «ser menor o igual» amb el símbol $\leq$, es podria definir de manera semblant la relació «ser major o igual» amb el símbol $\geq$. En qualsevol dels casos, si eliminem la possibilitat d'igualtat entre els nombres, les relacions definides es converteixen en altres d'ordre estricte que s'anomenen «ser menor estrictament» $\mathrm{o}$ «ser major estrictament» i es representen amb els símbols $<\mathrm{i}>$, respectivament.

En aquest moment comencen a tenir més sentit les paraules cardinal i ordinal. L'aspecte cardinal del nombre natural serà el que es refereix a les quantitats, és a dir, als cardinals dels conjunts i l'ordinal serà el que designa l'ordre i estableix comparacions entre els cardinals dels conjunts per a ordenar-los. 


\section{Sistemes de numeració}

Encara que la construcció del sistema de numeració decimal no forma part en sentit estricte dels continguts numèrics per desenvolupar a l'aula d'infantil, considerem important que el personal docent conega l'evolució i l'ampliació del camp numèric, així com les regularitats que emmarquen el funcionament de la seua representació. Per atendre a aquest interés presentem els dos apartats següents que es refereixen a l'evolució històrica $\mathrm{i}$ al funcionament dels sistemes de numeració (vegeu 3.2 d'aquest tema).

\subsection{Evolució històrica}

No sabem amb seguretat quan va començar l'ésser humà a necessitar un sistema d'escriptura de nombres, és a dir, un sistema de numeració, però sembla segur que uns dels primers instruments utilitzats per a comptar van ser els dits de la mà (Ifrah, 2001). Això implicaria que les primeres representacions numèriques es farien agafant com a referent el cinc i, posteriorment, es referiren al deu pel fet que es podien utilitzar els dits d'ambdues mans. Sembla que la humanitat usava la quantitat «deu» com a referent quan el llenguatge parlat es va consolidar. Si més no, és el que podem deduir, en l'àmbit indoeuropeu, del nostre sistema numèric i del nom d'alguns nombres com ara deu, en llatí decem; onze, en llatí undecim (un més deu); dotze, en llatí duodecim (dos més deu). Fins i tot es podria pensar en una base (vegeu 3.2 d'aquest tema) vint, tot comptant els dits dels peus i les mans (en llatí viginti).

No obstant això, quan va créixer la necessitat de representar nombres més grans, era possible escriure grups de cinc ratlles (IIIII) fins a arribar a la quantitat que es volia. Un exemple d'aquest mètode és un os de llop trobat a Txèquia on apareixen 55 incisions bastant profundes dividides en grups de cinc. Aquest os té uns 35.000 anys d'edat aproximadament. No cal dir que aquest sistema (de representació simple) primitiu i antic no constituïa una eina eficaç per a un càlcul desenvolupat.

A partir del III mil·lenni aC, els egipcis van utilitzar un sistema numèric (d'agrupament múltiple) procedent de la seua escriptura jeroglífica. Aquest sistema de base 10 utilitzava signes diferents per a les unitats, les desenes, les centenes, etc. En la figura 44 es veu com una determinada potència de deu podia tenir representacions gràfiques molt semblants però no idèntiques.

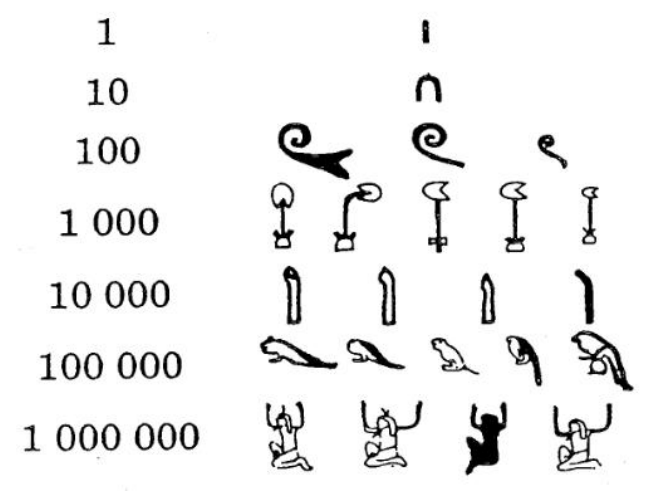

Figura 44. Símbols en l'escriptura jeroglífica egípcia (Ifrah, 1988) 
Permetia escriure nombres grans i oferia una gran innovació respecte als antics sistemes. Cal dir, però, que el procediment de composició consistia en repetir els símbols de la mateixa manera que l'home primitiu repetia les ratlles. En l'escriptura jeroglífica s'escrivia indistintament d'esquerra a dreta o de dreta a esquerra. Els signes numèrics modificaven la seua orientació en funció d'aquests sentits d'escriptura. A la figura 45, on es representa el 2.425 , es veu com l'orientació dels símbols és diferent a la de la figura 44.

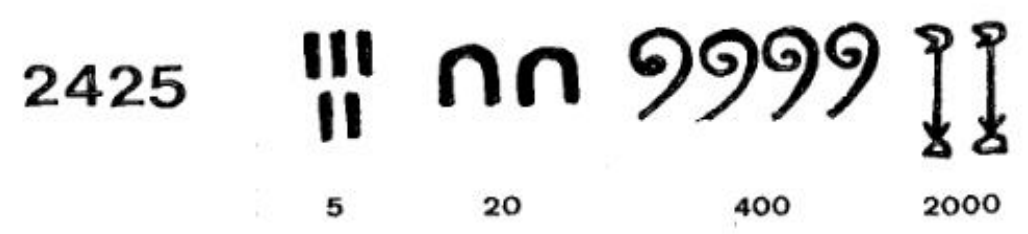

Figura 45. Escriptura jeroglífica del nombre 2.425 (Ifrah, 1988)

Els mateixos egipcis, poc després, van utilitzar un sistema de numeració més modern i més pràctic relacionat amb l'escriptura hieràtica. El sistema continuava sent decimal, però no era necessari repetir constantment els caràcters, sinó que se n'havien introduït uns de nous que indicaven quantes vegades es repetia cada símbol (sistema d'agrupament multiplicatiu).

Aquest canvi que trobem en el papir Rhind, també anomenat d'Ahmes, (s. XVII aC), conservat en el British Museum de Londres, ens mostra un aspecte que havia de ser fonamental per als nostres sistemes de numeració: la no necessitat de repetir els símbols.

El sistema de numeració que utilitzaven els grecs al voltant del $600 \mathrm{aC}$, concretament els atenesos, xifrava les quantitats amb la primera lletra del nom del nombre corresponent, era un sistema acrofònic. Les unitats fins al 4 es representaven per ratlles, el nombre 5 es representava per la lletra PI majúscula per ser PENTE el nom grec d'aquesta quantitat, pel 10 s'utilitzava la lletra DELTA majúscula per ser DEKA el nom d'aquest nombre, etc. També es van crear símbols mixtos a partir del cinc: si s'afegia el símbol del deu inscrit simbolitzava el 50, si era el del cent, 500, si el del mil, 5.000 (figura 46). 


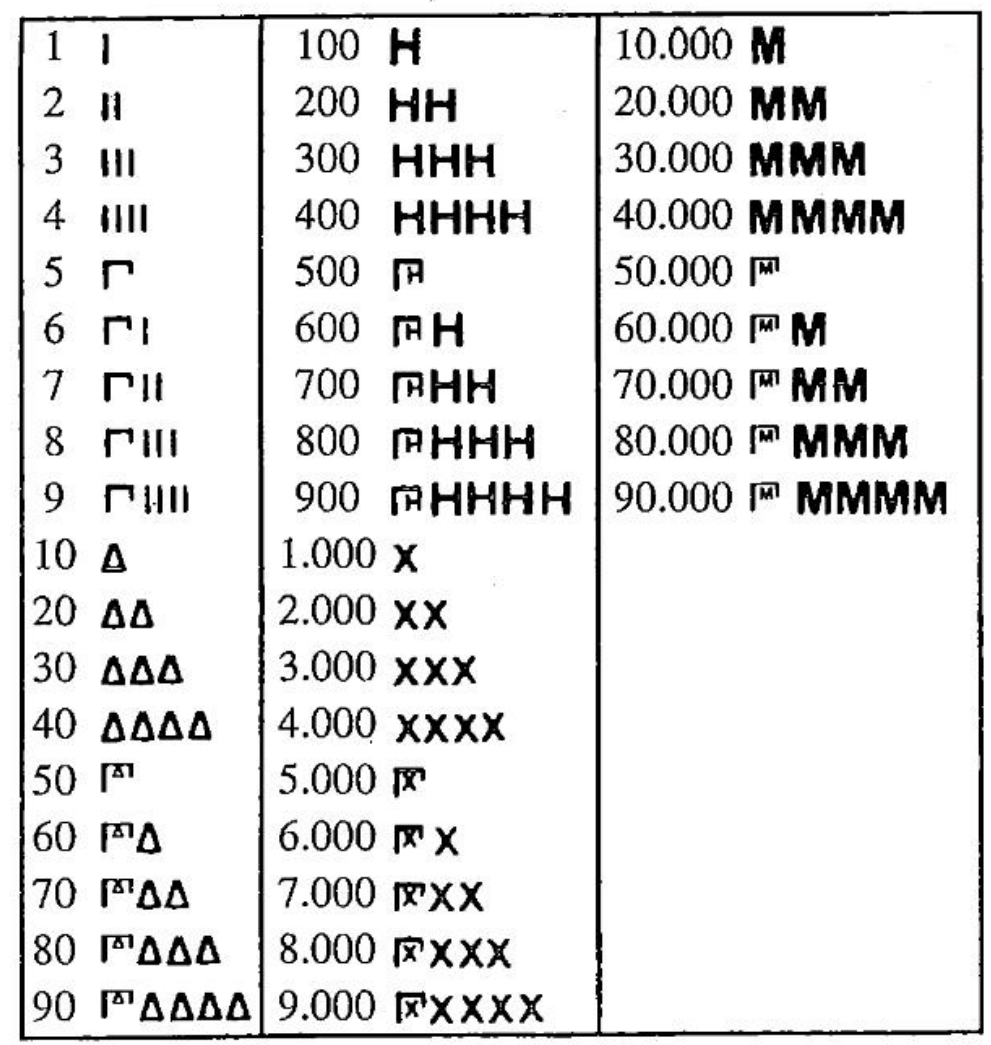

Figura 46. Representacions numèriques en l'escriptura acrofònica grega (Ifrah, 1988)

En la figura 47 es mostra un exemple de la representació del nombre 7.699, usant les xifres de la taula anterior.

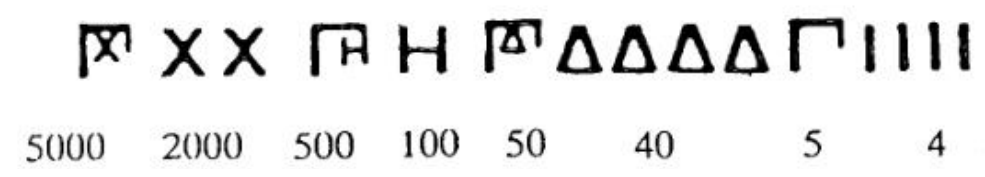

Figura 47. Escriptura acrofònica del nombre 7.699 (Ifrah, 1988)

Poc després, aquest sistema numèric va ser substituït per un altre que feia servir totes les lletres de l'alfabet grec (acompanyades d'una barra horitzontal a la part superior quan representaven nombres) i alguns altres símbols procedents de l'alfabet fenici (figura 48).

\begin{tabular}{|c|c|c|c|c|c|c|c|c|c|c|c|}
\hline A & $\alpha$ & alpha & 1. & I & $\iota$ & iota & 10 & $\mathbf{P}$ & $\rho$ & ro & 100 \\
\hline B & $\beta$ & beta & 2 & $\mathbf{K}$ & $\kappa$ & kappa & 20 & $\Sigma$ & $\sigma$ & sigma & 200 \\
\hline$\Gamma$ & $\gamma$ & gamma & 3 & $\Lambda$ & $\lambda$ & lambda & 30 & $T$ & $\tau$ & tau & 300 \\
\hline$\Delta$ & $\delta$ & delta & 4 & M & $\mu$ & $\mathrm{mu}$ & 40 & $\mathbf{Y}$ & $v$ & upsilon & 400 \\
\hline E & $\epsilon$ & epsilon & 5 & $\mathbf{N}$ & $v$ & $\mathrm{nu}$ & 50 & $\Phi$ & $\phi$ & phi & 500 \\
\hline$\Sigma$ & 5 & digamma & 6 & $\Xi$ & $\xi$ & ksi & 60 & $\mathrm{X}$ & $x$ & khi & 600 \\
\hline $\mathrm{Z}$ & $\zeta$ & dzeta & 7 & O & $\sigma$ & omicron & 70 & $\Psi$ & $\psi$ & psi & 700 \\
\hline H & $\eta$ & eta & 8 & П & $\pi$ & pi & 80 & $\Omega$ & $\omega$ & omega & 800 \\
\hline$\Theta$ & $\theta$ & thêta & 9 & $G$ & 9 & qoppa & 90 & $m$ & $\lambda$ & san & 900 \\
\hline
\end{tabular}

Figura 48. Numeració alfabètica grega (Ifrah, 1988) 
Amb aquest sistema es podrien xifrar els nombres que van de l'u al nou-cents noranta-nou. Per a escriure els milers, afegien una coma a la part esquerra superior de la lletra; així una ' $\alpha$ indicava mil, i una 'i indicava deu mil. Amb aquest sistema es podia escriure fins al nou-cents noranta-nou mil nou-cents noranta-nou.

Tot seguint l'exemple grec, els romans van utilitzar també les lletres de l'alfabet per a escriure els nombres d'acord amb els valors de la figura 49.

\begin{tabular}{|ll|ll|ll|}
\hline un & I & deu & $\mathrm{X}$ & cent & $\mathrm{C}$ \\
dos & II & vint & $\mathrm{XX}$ & dos-cents & $\mathrm{CC}$ \\
tres & III & trenta & $\mathrm{XXX}$ & tres-cents & $\mathrm{CCC}$ \\
quatre & IV & quaranta & $\mathrm{XL}$ & quatre-cents & $\mathrm{CD}$ \\
cinc & V & cinquanta & $\mathrm{L}$ & cinc-cents & $\mathrm{D}$ \\
sis & VI & seixanta & LX & sis-cents & DC \\
set & VII & setanta & LXX & set-cents & DCC \\
vuit & VIII & vuitanta & LXXX & vuit-cents & DCCC \\
nou & IX & noranta & XC & nou-cents & CM \\
\hline
\end{tabular}

Figura 49. Numeració romana

El principi d'equivalències era molt semblant al grec, de manera que la unitat era simbolitzada per una I, i es podia repetir al principi fins a quatre vegades IIII (4). La unitat següent era $\mathrm{V}$, que simbolitzava el 5. Més endavant es va introduir la regla segons la qual només es permet repetir qualsevol xifra fins a tres vegades. Així, per a expressar el nombre 4, es resta una unitat de la xifra següent IV (4). En general, quan dues xifres van juntes, la inferior se suma a la superior si va a la dreta (VI) i es resta si va a la esquerra (IV), tenint en compte que les úniques xifres que resten són: I davant de $\mathrm{V}$ i X, X davant de L i C, i C davant de $\mathrm{D}$ i M (mil). Així, per exemple, el 999 s'escrivia CMXCIX.

El mecanisme més utilitzat per a escriure nombres superiors al mil era posar una ratlla dalt de qualsevol símbol, que indicava que aquest s'havia de multiplicar per mil; el dos mil, per exemple, s'escrivia $\overline{I I}$, i el deu mil, $\bar{X}$. Així, per exemple, el 3.749 s'escrivia bé MMMDCCXLIX, o bé $\overline{I I I} D C C X L I X$.

Però el sistema de numeració més modern i pràctic va nàixer a l'Índia al voltant del segle III aC. Conservava la base decimal i el caràcter d'agrupament multiplicatiu del sistema egipci. Cap al segle $v$ de la nostra era es va incorporar a aquest sistema un canvi fonamental respecte dels anteriors, que consistia en la introducció d'un guarisme per a escriure la xifra zero, que indicava la absència d'algun ordre d'unitats en el nombre, obtenint així un sistema de numeració on el valor de cada xifra depenia de la posició que ocupava en la representació del nombre (sistema de numeració posicional: d'agrupament multiplicatiu, amb valor posicional de les xifres i amb ús de la xifra zero). 
Aquestes xifres hindús van anar estenent-se i adoptant formes diverses en diferents llengües. Els àrabs adoptaren els sistemes d'escriptura numèrica que havien après dels grecs i els hindús i utilitzaren tots dos. Però introduïren a Occident, al voltant del segle $\mathrm{x}$, el sistema de numeració que triomfaria i s'impondria als altres, i que va rebre el nom de numeració aràbiga o indoaràbiga, les xifres inicials de la qual eren les que es representen en la figura 50.

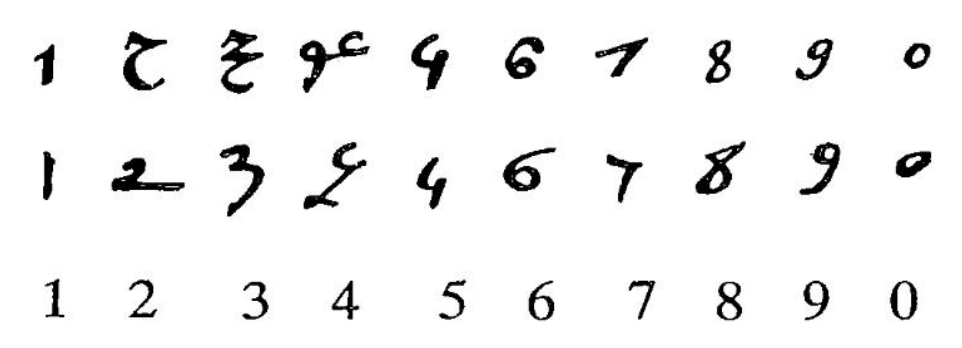

Figura 50. Xifres àrabs (Ifrah, 1988)

En el món cristià, es va adoptar aquest sistema hindú i àrab perquè oferia uns grans avantatges respecte del romà i, encara que es va fer públic al segle XIII arran de l'edició del Liber abaci de Leonardo de Pisa, Fibonacci, no es va utilitzar de manera normalitzada fins al segle xv, en el qual la impremta va fer possible que el seu coneixement arribara a una franja de població molt més àmplia que al principi. Les xifres del sistema hindú han evolucionat al llarg del temps fins a arribar als nostres dies. En la figura 51 s'il·lustren els primers passos d'aquesta evolució.

\begin{tabular}{|c|c|c|c|c|c|c|c|c|c|c|}
\hline Fechas & 1 & 2 & 3 & 4 & 5 & 6 & 7 & 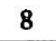 & 9 & 0 \\
\hline $\begin{array}{l}\text { siglo } \\
\text { XII }\end{array}$ & 1 & $\begin{array}{l}3 \\
3\end{array}$ & $\begin{array}{l}\mathbf{3} \\
3\end{array}$ & $R$ & $\begin{array}{l}y \\
5\end{array}$ & $\begin{array}{l}6 \\
6\end{array}$ & 7 & 8 & 2 & - \\
\hline $\begin{array}{l}\text { siglo } \\
\text { XIII }\end{array}$ & 1 & 7 & 3 & 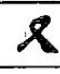 & 4 & 6 & $\Lambda$ & 0 & 9 & 6 \\
\hline $\begin{array}{l}\text { siglo } \\
\text { XIV }\end{array}$ & 2 & $z$ & 3 & 8 & 4 & $\mathbb{b}$ & 1 & 8 & 9 & 0 \\
\hline $\begin{array}{l}\text { siglo } \\
\text { Xv }\end{array}$ & $\mathbb{Z}$ & 2 & 3 & $l$ & 5 & 6 & A & 8 & $?$ & 8 \\
\hline $\begin{array}{l}\text { hacia } \\
1524\end{array}$ & ' & $z$ & 3 & $\ell$ & 5 & 6 & $\wedge$ & 8 & 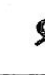 & - \\
\hline
\end{tabular}

Figura 51. Evolució de les xifres àrabs a Europa (Ifrah, 1988)

Altres civilitzacions o societats han tingut sistemes de numeració diferents. Alguns exemples dels quals són: el xinés al $1500 \mathrm{aC}$., el babilònic al s. XIII aC. i el maia al s. XII aproximadament. Es pot trobar àmplia informació sobre aquests $i$ altres sistemes de numeració en Ifrah (1988 i 2001). 


\subsection{Definició i tipus}

Un Sistema de Numeració és un conjunt de normes i convenis per a llegir i escriure nombres utilitzant la menor quantitat de símbols possible.

Caldrà tornar a la història, una altra vegada, per a entendre qüestions importants dels sistemes de numeració i la depuració que han sofert per causes d'economia d'escriptura, de dificultat i, de vegades, religioses.

Quan l'ésser humà va començar a comptar va usar els dits, pedres, marques en bastons, nusos en una corda i d'altres formes per a passar d'un nombre al següent. A mesura que la quantitat creix, es fa necessari un sistema de representació més pràctic. En diferents parts del món $i$ en èpoques distintes es va arribar a la mateixa solució: quan s'aconsegueix un determinat nombre d'unitats (de primer ordre) s'agrupen i es fa una marca diferent, que representa aquest grup (unitat de segon ordre). A la quantitat d'unitats d'un ordre necessària per a obtenir una unitat de l'ordre següent se l'anomena base del sistema de numeració. Es continua afegint unitats de primer ordre fins que es torna a aconseguir per segona vegada el nombre anterior i s'hi afegeix una altra marca de la segona classe. I així, s'hi continua formant unitats de segon ordre fins a arribar a un nombre d'elles igual a la base. Aleshores s'agrupen aquestes unitats de segon ordre i s'introdueix una marca diferent per representar aquesta nova unitat (de tercer ordre). Procedint de manera semblant $\mathrm{i}$ de forma successiva es van construint els diferents ordres superiors d'unitats.

La base que més s'ha utilitzat al llarg de la història és la base 10, segons totes les aparences, perquè aquest és el nombre dels dits de les mans de l'ésser humà. Hi ha alguna excepció notable, com ara la numeració babilònica, que usava 10 i $60 \mathrm{com}$ a bases, i la numeració maia, que usava 20 i 5, encara que amb alguna irregularitat. Des de fa 5.000 anys, la gran majoria de les civilitzacions ha comptat en unitats, desenes, centenes, milers, etc., és a dir, de la mateixa manera com continuem fent-ho avui.

No obstant això, la forma d'escriure els nombres ha estat molt diversa i molts pobles han vist impedit el seu avanç científic per no disposar d'un sistema de numeració que permetera utilitzar uns procediments eficaços per al càlcul. Quasi tots els sistemes utilitzats representen amb exactitud els nombres naturals, encara que en alguns es poden confondre uns nombres amb altres (en el del sistema egipci d'agrupament multiplicatiu, per exemple). Molts d'aquests no són capaços de representar grans quantitats i d'altres requereixen un nombre de símbols tan gran que els fa poc pràctics. A més, no permeten, en general, efectuar operacions tan senzilles com la multiplicació i exigeixen procediments molt complicats que només estaven a l'abast d'uns pocs iniciats. Pel que fa a la divisió, és molt més greu, ja que no existien regles per a poder fer-la. De fet, quan es va començar a utilitzar a Europa el sistema de numeració actual, els abaquistes, professionals del càlcul, es van oposar amb les més peregrines raons, entre les quals hi havia la següent: «Sent el càlcul quelcom complicat en si mateix, hauria de ser un mètode diabòlic aquell que permetera efectuar les operacions de manera tan senzilla». 
El sistema actual va ser inventat pels indis i transmès a Europa pels àrabs, com ja s'ha esmentat anteriorment. De l'origen indi del sistema hi ha suficients proves en documents indis i àrabs. Leonardo de Pisa (Fibonacci), va ser un dels introductors del nou sistema a l'Europa de 1202. El gran mèrit dels indis va ser la utilització del zero amb valor numèric per a ocupar diferents posicions en la representació dels nombres, la qual cosa evita confusions i permet un sistema en què només deu símbols poden representar qualsevol nombre encara que siga molt gran, i simplificar la manera d'efectuar les operacions.

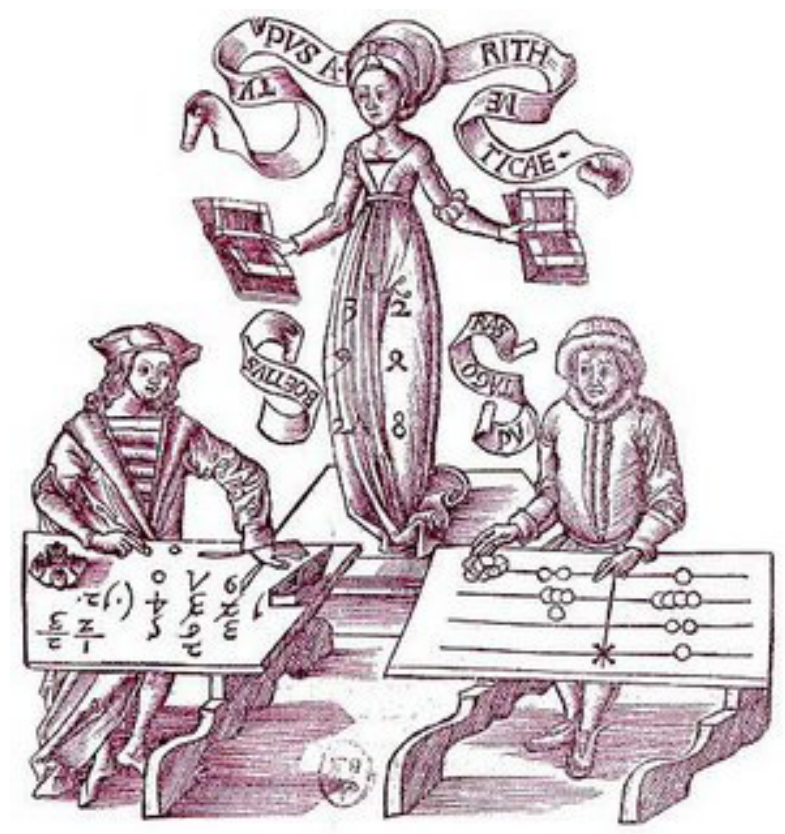

Figura 52. Gravat del començament del segle Xvi que representa el triomf dels algorismes sobre els àbacs. Els algoristes, emprant les nou xifres i el zero, s'imposen als abaquistes, ja que són capaços de fer més ràpidament les operacions aritmètiques. En segon pla, la dama Aritmètica, amb un vestit guarnit de xifres, mostra amb la mirada quines són les seues preferències (Ifrah, 1988)

La introducció d'aquest sistema de numeració que ara fem servir com si haguera existit des de sempre no va ser fàcil. En el segle Xvi, tres-cents anys més tard de la seua introducció a Europa per Fibonacci, encara es feien competicions entre $a b a-$ quistes, que feien servir l'àbac, i algoristes, que feien els comptes més o menys com nosaltres ara (figura 52). Els àbacs van resistir, malgrat tot, fins al segle Xx, quan encara es podien trobar als bancs, comerços, etc., sobretot de països orientals.

\subsubsection{Sistemes de numeració additius}

Per veure com funciona la representació numèrica en un sistema additiu, considerem el sistema jeroglífic egipci. Per cada unitat s'escriu un traç vertical, per cada desena un símbol en forma d'arc i per cada centena, miler, desena i centena de miler i milió, un jeroglífic específic. Així, per a escriure 754 feien servir 7 jeroglífics de centenes, 5 de desenes i 4 traços. D'alguna manera, totes les unitats estan físicament presents. 
Els sistemes additius són aquells que acumulen els símbols de totes les unitats, desenes..., necessaris fins a completar el nombre. Una de les seues característiques és, per tant, que es poden posar els símbols en qualsevol ordre, encara que, en general, és preferible una disposició determinada. Cada xifra té un valor propi que no depén del lloc que ocupa i es diuen additius perquè, per tal de conèixer-ne el nombre, s'ha de fer una addició. Com ja s'ha comentat, les dificultats de representar nombres grans i les complicacions que hi havia a l'hora d'operar, feren que no prosperaren.

\subsubsection{Sistemes de numeració posicionals}

Aquests sistemes es basen en el principi del valor relatiu; és a dir, cada xifra representa valors diferents depenent de la posició que ocupe en l'expressió del nombre. L'exemple per excel·lència seria el Sistema de Numeració Decimal (a partir d'ara SND), però n'hi ha d'altres que també l'utilitzen i que s'explicaran més endavant. La base (vegeu 3.2 d'aquest tema) suposa un punt d'inflexió en la col·locació de les xifres. És a dir, si un sistema de numeració posicional té base $\boldsymbol{b}$ significa que «b unitats de qualsevol ordre formen una unitat d'ordre immediat superior», com s'ha esmentat anteriorment. La base representa també la quantitat de xifres que el sistema utilitza, és a dir, $\boldsymbol{b}$ és el nombre de símbols diferents permesos en un sistema de numeració posicional per a escriure els nombres.

Analitzem l'snd. La base serà 10 i s'utilitzen com a xifres $0,1,2,3 \ldots, 9$. Per a representar quantitats inferiors a 10 , unitats de primer ordre o unitats, s'utilitza una sola xifra.

En arribar a la base, és a dir, la quantitat que s'obté en afegir 1 al 9, el sistema utilitza el criteri posicional i necessita dues xifres per a representar el nombre en el qual hi ha un grup i cap unitat solta. Cadascun d'aquests grups formats per 10 unitats s'anomena desena o unitat de segon ordre. Per a expressar dotze, per exemple, s'escriu 12. Utilitzem dues xifres: la que s'escriu més a l'esquerra, l'1, és la xifra de les desenes, mentre que el 2 és la xifra de les unitats. Però en el fons estem escrivint:

$$
\mathbf{1} \times 10+\mathbf{2}=\mathbf{1 2}
$$

Agafant un altre exemple, $72: 7 \times 10+\mathbf{2}=\mathbf{7 2}$.

De la mateixa manera, en passar al graó següent, la centena, s'ha de recórrer a una nova posició a l'esquerra de les anteriors, per a escriure xifres que indiquen grups de 10 desenes, per exemple 325: $\mathbf{3} \times 100+\mathbf{2} \times 10+\mathbf{5}=\mathbf{3 2 5}$. I així successivament.

Hi podríem posar molts exemples, $8.795: \mathbf{8} \times 1.000+\mathbf{7} \times 100+\mathbf{9} \times 10+\mathbf{5}=\mathbf{8 . 7 9 5}$. Si la quantitat és molt gran, representem l'u seguit de zeros, utilitzant potències de 10:

$$
\mathbf{9} \times 10^{6}+\mathbf{6} \times 10^{5}+\mathbf{5} \times 10^{3}+\mathbf{3} \times 10+\mathbf{2}=\mathbf{9 . 6 0 5 . 0 3 2} .
$$


Aquesta manera de representar els nombres s'anomena descomposició polinòmi$c a$. Cal notar que quan en un nombre no existeixen unitats d'un determinat ordre, es col·loca un zero en la posició corresponent, però, en la descomposició polinòmica no apareix. Simplement, a l'exemple anterior, els sumands que representarien $\mathbf{0} \times 10^{4}$ o $\mathbf{0} \times 10^{2}$, s'obvien.

A les unitats no cal posar potència de 10 , perquè seria amb exponent 0 , ja que $10^{0}$ $=1$. Tampoc cal explicitar l'exponent de la potència $10^{1}$; per tant, $25=2 \times 10^{1}+5$ $\times 10^{0}$ ho escrivim $25=2 \times 10+5$.

El funcionament de l'sND es reprodueix en cada sistema posicional siga aquest de la base que siga, exceptuant la utilització del punt o qualsevol altra marca per separar els blocs de tres xifres, els noms de les diferents ordres d'unitats (és a dir, unitats, desenes, centenes..., queda reservat únicament per a l'sND) i la manera de llegir els nombres (per exemple, 132 es llegeix «cent trenta-dos», mentre que $132_{(4}$ es llegeix «u, tres, dos en base quatre»).

Si utilitzem diferents sistemes de numeració per a representar un nombre, n'obtenim diverses expressions que s'anomenen numerals. Així, per exemple: 7, $21_{13}$, VII..., són numerals que corresponen a la quantitat de dies d'una setmana. Com que generalment el treball amb nombres i operacions es fa referit a un sol sistema de numeració, s'assimila la paraula numeral a la paraula nombre i s'utilitzen indistintament.

Desenvolupem a continuació alguns exemples de sistemes posicionals en altres bases.

\section{Sistema de numeració en base 5}

És un sistema que s'ha utilitzat al llarg de la història pel fet que 5 és el nombre dels dits d'una mà. Utilitza les xifres $0,1,2,3$ i 4, i es canvia d'ordre d'unitats afegint una xifra a l'esquerra del numeral, quan s'arriba a un agrupament de 5 unitats de qualsevol ordre (per la qual cosa mai ha d'aparèixer el valor de la base entre les xifres d'un nombre, ni cap superior a ella).

Quan tenim expressada una quantitat en base 5, podem saber el numeral que li correspon en l'SND a partir d'unes senzilles operacions d'addició i multiplicació. Suposem que el nombre, escrit en base 5, és $23401_{(5}$. Si volem saber quin és el seu valor en l'SND, caldrà desenvolupar la seua descomposició polinòmica en la base 5 i realitzar les operacions que s'hi indiquen:

$$
\mathbf{2 3 4 0 1}_{(5}=2 \times 5^{4}+3 \times 5^{3}+4 \times 5^{2}+1=2 \times 625+3 \times 125+4 \times 25+1=\mathbf{1 . 7 2 6} .
$$

El paper de les potències de 10 en l'SND, en aquest moment, el fan les potències de 5 . 
Recíprocament, també es pot passar un numeral expressat en l'sND a un sistema de base 5. Utilitzant els mateixos nombres d'abans, suposem que volem escriure en base 5 el nombre 1.726. Numèricament, el procediment que s'ha de seguir consisteix a dividir per 5 el $1.726 \mathrm{i}$, successivament, els diferents quocients que obtenim en cada divisió fins arribar a un quocient menor que 5, ordenant a continuació els resultats de les diferents divisions. En el numeral que busquem, l'últim quocient serà la xifra de les unitats de l'ordre més alt i els residus de les divisions, collocats en ordre invers al de la seua obtenció, seran les xifres dels següents ordres descendents.
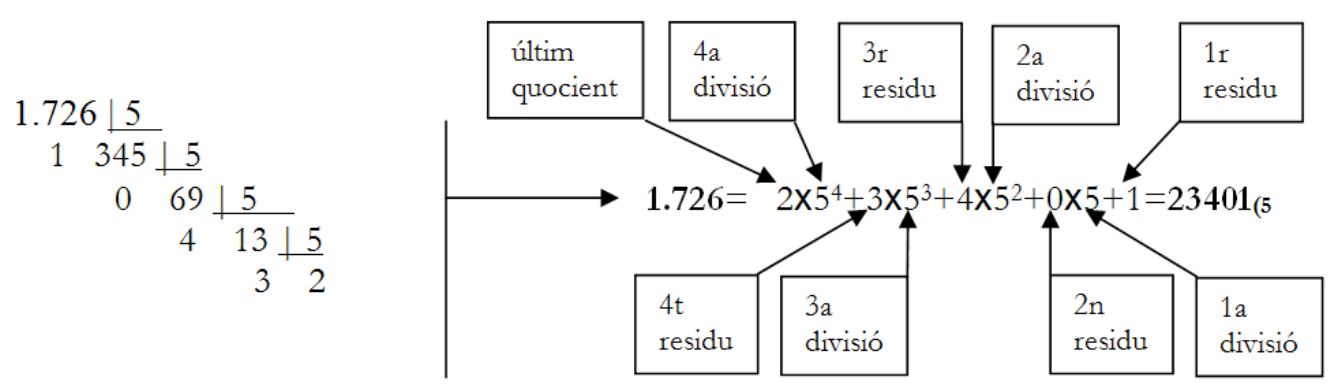

Manipulativament, és com si tinguérem 1.726 peces soltes i el que se'ns demana és fer munts de 5 peces, després de 5 munts, a continuació de 5 munts de 5 munts, i així mentre puguem, ordenant els resultats obtinguts en cada tipus d'agrupament de manera anàloga al cas numèric.

\section{Sistema de numeració en base 2}

És un sistema que s'utilitza molt en l'actualitat en informàtica i en tecnologia. Qualsevol informació s'enregistra mitjançant zeros i uns.

Utilitza les xifres 0 i 1 i es canvia d'ordre d'unitats afegint una xifra a l'esquerra del numeral quan s'arriba a un agrupament de 2 unitats de qualsevol ordre.

Seguint un procés semblant al descrit per a la base 5, si agafem el $100 \mathrm{i}$ volem passar-lo a base 2, dividim successivament per dos fins a obtenir un quocient menor que aquest nombre i després ordenem les xifres. Així:

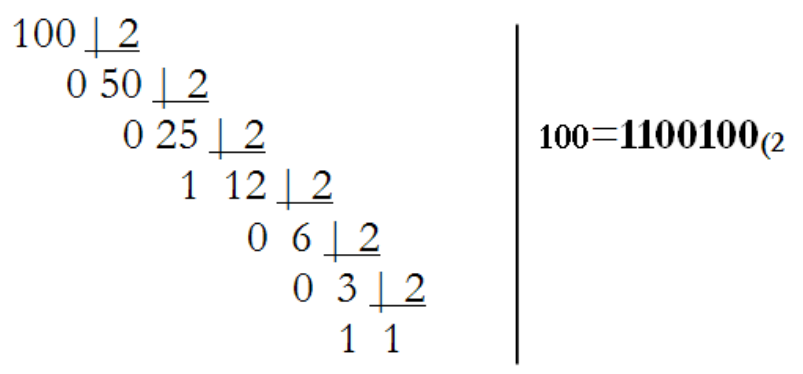


Per esbrinar el valor d'aquesta expressió en base 10, escrivim la descomposició polinòmica corresponent $\mathrm{i}$ realitzem els càlculs:

$$
\mathbf{1 1 0 0 1 0 0}_{(2}=1 \times 2^{6}+1 \times 2^{5}+1 \times 2^{2}=64+32+4=\mathbf{1 0 0} .
$$

\section{Sistema de numeració duodecimal}

En el segle XVIII, el naturalista francès Georges-Louis Leclerc, comte de Buffon (1707-1783), va proposar l'adopció del sistema duodecimal, de base dotze, que ja es coneixia de l'antiguitat, per aplicar-lo a les unitats de mesura (Ifrah, 1988).

La raó és fàcil de comprendre: el 10 és un nombre molt gran per a l'escassa quantitat de divisors enters que té. Descartant els obvis 1 i 10, només és divisible per 2 i per 5. En canvi, el dotze, un poc més gran, té més divisors. A més de l'1 i el mateix 12, trobem el 2, el 3, el 4 i el 6 . Aquests divisors eren importants per dues coses: fraccionar la quantitat de mercaderies i el preu de les unitats de mesura dels productes; així, calcular preus i tornar diners era una tasca més senzilla. El costum que hi ha avui de comptar les mercaderies per dotzenes i d'utilitzar en alguns països unitats de mesura que es relacionen entre si de dotze en dotze (un peu, 12 polzades; un xíling, 12 penics; etc.) té l'origen en aquest sistema.

\section{Sistema de numeració sexagesimal}

Aquest sistema és heretat dels babilonis i els sumeris. La base és 60 i en l'actualitat es continua utilitzant per a mesurar el temps i els angles. Es pot considerar que s'ha mantingut fins als nostres dies per la importància que van tenir els càlculs astronòmics i trigonomètrics dels matemàtics antics. Igual que el sistema de numeració duodecimal, la gran quantitat de divisors que té el 60 (és el menor nombre que es pot dividir al mateix temps per $2,3,4,5$ i 6) el feia òptim per a aquest tipus de càlculs.

En l'actualitat, aquest sistema funciona únicament amb tres ordres d'unitats: segons, minuts i hores o graus, segons s'estiga mesurant temps o angles. D'aquesta manera, 60 segons ( $1 \mathrm{r}$ ordre) faran 1 minut ( $2 \mathrm{n}$ ordre) i 60 minuts faran bé una hora, bé un grau ( $3 \mathrm{r}$ ordre). A partir d'aquest ordre, les dues magnituds han evolucionat de manera diferent per tal de construir les noves unitats. Així, en el cas del temps, els dies, les setmanes, els mesos, els anys, etc., ja no s'han format agrupant 60 unitats de l'ordre anterior. En el cas de la mesura d'angles, no hi ha unitat d'ordre superior al grau, ja que l'angle recte, de $90^{\circ}$, el pla, de $180^{\circ}$ i el complet, de $360^{\circ}$, no s'han format agrupant 60 unitats de l'ordre anterior.

La nomenclatura que s'usa en aquest sistema és diferent de la dels altres sistemes de numeració i representa separadament les quantitats que corresponen a cadascun dels ordres del nombre, per això utilitza les xifres del sistema de numeració decimal. Si el que es mesura és el temps o són angles, s'utilitzen maneres diferents 
d'expressar els ordres de les unitats. En el cas del temps, escriurem $h$ per a indicar les hores, min per a indicar els minuts is per a indicar els segons, per exemple, $5 \mathrm{~h} 15$ min $43 \mathrm{~s}$. Per al cas de la mesura d'angles, escriurem ${ }^{\circ}$ per a indicar els graus, ' per a indicar els minuts i " per a indicar els segons, per exemple $35^{\circ} 42^{\prime} 33^{\prime \prime}$.

El pas d'una expressió numèrica del sistema de numeració decimal al sistema de numeració sexagesimal, o a l'inrevés, vol dir poder expressar una mateixa quantitat en els dos sistemes de numeració o a partir d'una expressió arribar a l'altra. Així és que farem servir la proporcionalitat, és a dir, expressarem amb proporcions les equivalències entre els decimals i les agrupacions de 60 (minuts o segons).

De manera quotidiana, cal evitar interferències incorrectes entre el sistema decimal i el sistema sexagesimal. Així:

- Cinc hores i mitja no són 5,30h; són 5,5 h o bé 5 h 30 min

- Tres quarts d'hora no són 0,45 h; són 0,75 h o bé 45 min

- Un quart d'hora no és 0,15 h; és 0,25 h o bé $15 \mathrm{~min}$

\section{Els nombres naturals a l'aula d'infantil}

\subsection{Consideracions prèvies}

Quan l'alumnat d'educació infantil comença la seua escolarització no és la primera vegada que té accés als nombres, fet que cal tenir molt present. La quotidianitat amb la qual el nombre es presenta en el nostre medi, siga parlat o siga escrit, en qualsevol de les diferents manifestacions de comunicació que establim, fa que estiga com a habitual en el seu conscient des d'edats molt primerenques la presència d'uns signes, grafies o guarismes que expliquen coses que passen al seu voltant.

Vol dir açò que hi ha una idea formada a dintre seu de què signifiquen aquests nombres? Segurament no, i eixa és la tasca que cal desenvolupar en l'educació infantil: que el nombre siga entés com l'eina matemàtica que les persones han ideat per tal de representar, simbolitzar, anomenar les quantitats i ordenar-les. Això en un primer moment. És evident que hi ha més usos del nombre natural, però aquestes dues funcions són l'objectiu principal del tema. Estem parlant de les funcions cardinal i ordinal, que de ben segur han estat incorporades de manera intuïtiva al pensament dels xiquets i les xiquetes abans d'entrar a l'escola, «tinc més joguines que tu» $\mathrm{o}$ «he acabat el primer». Aquestes dues idees podem considerar-les com a punt de partida a l'hora de treballar la numeració en educació infantil.

Referit als continguts, si la pregunta és, «què es fa de 3 a 6 anys en relació al bloc de nombres?», la resposta és clara: «Del 0 fins al 9». Tan simple sembla, però pot arribar a ser bastant complicada. No pel treball que cal desenvolupar a l'aula, allò difícil pot tenir la seguretat que el binomi quantitat-nombre està perfectament 
assolit fins al nou, així com el seu ordre. Almenys hem de plantejar-nos com a objectiu aconseguir aquesta seguretat. No oblidarem reflexionar sobre el fet que la quantitat és una noció independent de les característiques sensorials o de les posicions dels objectes als quals s'hi refereix (i així cinc taules és la mateixa quantitat que cinc formigues, i no ens deixarem confondre per res aliè a l'esmentada quantitat). També cal treballar amb atenció les grafies d'aquests nombres, perquè l'habilitat del traç no està totalment desenvolupada en l'alumnat i la representació gràfica de les xifres no comença sent «d'impremta», és una grafia més quotidiana. És convenient observar per on comencen a escriure i amb quina orientació, per tal d'ajudar-los a aconseguir una representació clara dels nombres.

El fet de treballar del 0 al 9 no vol dir que no puguen veure en educació infantil nombres superiors al nou i amb més xifres. De fet, quan es passa llista, per exemple, o es mira la data en el calendari ja veuen nombres més alts. En aquests casos, l'aproximació que fan al nombre es basa sols en el seu dibuix i no en el valor o significat que tenen les xifres que el componen. Deixarem l'estudi de la formació de la desena i de la construcció de l'sND per a l'educació primària. Aleshores serà el moment d'introduir un nou concepte i una nova forma de procedir quan treballen els nombres, agrupar de deu en deu, la qual cosa resoldrà un problema que no és el de comptar, sinó el d'aclarir-nos en representar els nombres quan són molts els elements considerats.

I tot això sense oblidar que la numeració, com a part de les matemàtiques, té el seu punt de partida i d'arribada en la realitat, i que el nostre treball matemàtic a l'aula serà significatiu en la mesura que ho contextualitzem socioculturalment i l'integrem en un treball globalitzat que no deixe com un compartiment estanc qualsevol tipus de saber.

\subsection{Capacitats per desenvolupar a l'aula d'infantil}

Com establir els primers passos d'una manera seqüencial i adequada a l'educació infantil respecte dels nombres naturals serà l'objectiu del tema, contribuint a desenvolupar en l'alumnat les següents capacitats:

1. Establir comparacions entre quantitats d'objectes separats i expressar els resultats amb l'ajuda de quantificadors.

2. Comparar quantitats d'objectes separats amb l'ajuda dels aspectes quantitatius de les correspondències entre conjunts.

3. Conèixer els deu primers nombres naturals a partir de l'experiència amb conjunts d'objectes.

4. Formar i reconèixer conjunts que tinguen el mateix nombre d'elements que un donat.

5. Classificar conjunts segons el seu cardinal.

6. Formar i reconèixer conjunts que tinguen més o menys elements que un donat. Comparar els cardinals dels conjunts. 
7. Ordenar conjunts segons el seu cardinal i ordenar els cardinals d'aquests conjunts. Comptar progressivament i regressivament.

8. Expressar nombres ordinals en la seua numeració específica.

9. Utilitzar els nombres per tal de representar quantitats.

\subsection{Desenvolupament de les capacitats}

Amb les mateixes consideracions de l'apartat 3.3 del tema anterior, estudiarem ara els procediments per a la construcció dels conceptes que integren aquest tema a l'aula d'infantil.

\section{Establir comparacions entre quantitats d'objectes separats $i$ expressar els resultats amb l'ajuda de quantificadors}

En el moment que es vol iniciar la numeració, cobra sentit parlar d'unitat front als cardinals dels conjunts d'objectes que tenen més d'un element. És el singular i el plural el que està en el fons. Els xiquets i les xiquetes necessiten aïllar un element, saber que aquest és una unitat, per després enfrontar-se al que serà la multiplicitat d'un grup d'elements.

Atendrem aquesta necessitat treballant situacions de manipulació de quantitats i d'estimació, a grans trets, de les seues diferències quantitatives en comparar-les.

Abans d'entrar en el $2 \mathrm{n}$ cicle d'educació infantil, l'alumnat segurament haurà estat en contacte amb el concepte d'unitat en situacions quotidianes (un dit per a un any, un germà, una mamà...). A l'aula caldrà insistir al principi en la diferenciació de la unitat front a la multiplicitat i en la utilització de les paraules un o molts (també podria utilitzar-se l'expressió diversos) per a expressar cada cas.

Més endavant s'amplia el treball de quantificació de materials separats amb el coneixement d'alguns quantificadors que complementen els conceptes inicials, com per exemple molts contraposat a pocs, o tots (aquest quantificador s'ha esmentat en la capacitat 7 del tema 1, quan s'ha treballat la formació de conjunts) contraposat a cap. També inclourem quantificadors intermedis, com per exemple alguns, entre tots i cap. El docent utilitzarà de manera natural el vocabulari associat a aquests conceptes, fins a aconseguir que l'alumnat l'incorpore a les seues conversacions sense cap problema.

En els primers passos del desenvolupament d'aquesta capacitat treballarem exclusivament amb objectes reals en situacions quotidianes, per passar posteriorment a la realització d'activitats amb representacions gràfiques en les quals siga necessari utilitzar els quantificadors esmentats (dibuixar moltes estrelles en un mural en el qual hi ha pocs núvols -figura 53-, trobar poques vaques en la fotografia d'una granja on hi ha molts cavalls, descobrir que no hi ha cap xiquet o xiqueta en la imatge d'un carrer...). 


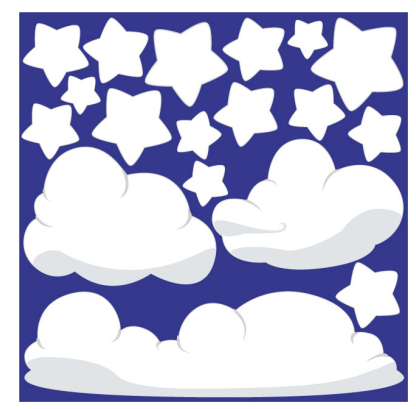

Figura 53. Representació de pocs núvols i moltes estrelles

La meta final d'aquest treball serà la quantificació exacta dels materials separats mitjançant el comptatge i per això utilitzarem més endavant els nombres naturals.

\section{Comparar quantitats d'objectes separats amb l'ajuda dels aspectes quantitatius de les correspondències entre conjunts}

La diferència entre aquesta capacitat i la primera és que ara es comprova, amb ajuda dels instruments matemàtics necessaris, si l'estimació de la comparació de quantitats realitzada per l'alumnat és correcta o no. En l'anterior es feia una apreciació intuïtiva, ara utilitzarem les correspondències biunívoques (en el cas de comparar cardinals diferents) o les aplicacions bijectives (en el cas de comparar cardinals iguals), per extreure conclusions quantitatives que ens permeten afermar o desmentir si el que s'havia apreciat de manera estimativa era cert o no.

Això ho farem ja des de l'inici del cicle treballant amb dos conjunts de cardinals molt contrastats, els elements dels quals siguen el més semblants possible (millor si són iguals). És a dir, si el que volem és que comparen quantitats i puguen arribar a expressar hi ha més_que _o hi ha menys_que _, intentarem que no siga una altra característica diferenciadora dels elements la que capte la seua atenció. Així, en comparar dos llapis i set llapis de colors (de la mateixa marca, longitud, grossària...), el que es pretén és que puguen percebre que la quantitat és diferent. Però si comparem dues taules i set llapis de colors, com que els elements són molt diferents, el nombre d'objectes deixa de ser la característica que més crida l'atenció i serà el volum, per exemple, cosa que els farà dir que n'hi ha més en les taules, quan realment, n'hi ha més en els llapis de colors.

També en aquest moment es pot començar a treballar el concepte d'igualtat respecte de la quantitat, aprofitant situacions o activitats que es presenten en classe. Per exemple, a l'aula es formen grups de tres xiquets o de tres xiquetes per fer un treball i se'ls demana que comproven que tots tenen el mateix nombre de membres. En qualsevol activitat d'aquest tipus caldrà que verbalitzen hi ha igual quantitat de _que de _ o hi ha tants de _com de _, quan es comprove la igualtat comparant els cardinals dels conjunts. 
Com que els elements que s'utilitzen són molt semblants, l'estimació de quantitats no presenta dubtes, generalment. En cas que sí es presentaren, caldria recórrer a les correspondències per tal d'assegurar les estimacions que hi facen. Així, s'establiria una correspondència biunívoca o una aplicació bijectiva entre els dos conjunts associant un a un els elements d'ambdós fins que en un d'ells (biunívoca) o en tots dos (bijectiva) no quede cap element.

Cap a la meitat de cicle, cal introduir alguna diferència entre els elements que formen els conjunts per comparar. Aquesta no ha de ser molt significativa, però s'ha de començar a separar la idea de quantitat de la idea de forma, color, grandària... En l'exemple anterior, es poden usar llapis de colors i retoladors per «marcar», o llibres i llibretes, és a dir, no són exactament els mateixos elements però s'assemblen prou. També augmentarem la dificultat disminuint la diferència entre els cardinals dels conjunts, insistint en la seua igualtat quan es produïsca i usant les expressions adients a cada situació: hi ha més_que , hi ha menys_que , hi ha igual de _que de_.

De la mateixa manera que al principi del cicle, usarem les correspondències per aclarir els dubtes que hi puguen sorgir. En aquest treball ampliarem el vocabulari de l'alumnat incorporant les paraules habituals en les correspondències, com ara cadascun, quelcom, uns, cap, no tots, almenys..., dotant-les de sentit en utilitzar-les en contextos adequats. Per exemple, en repartir tasques de classe per als xiquets i les xiquetes direm «cadascun ha de triar una tasca» o en associar alumnes amb cadires en una activitat de psicomotricitat, direm «no tots pujaran dalt d'una cadira, almenys tres es quedaran baix perquè han de fer un itinerari senyalat pels seus companys i companyes», etc.

Les situacions manipulatives esmentades fins ara es completaran amb activitats gràfiques en les quals es treballaran tots els conceptes anteriors a partir de conjunts representats en imatges, verbalitzant de nou les comparacions de quantitats que facen i utilitzant, quan siga necessari, correspondències gràfiques per tal de comprovar-les. En la figura 54 es mostra l'exemple amb animals de granja comentat en la capacitat 1 , on la gran diferència entre el nombre de vaques i el de cavalls fa innecessari representar la correspondència per saber que hi ha poques vaques $i$ molts cavalls.

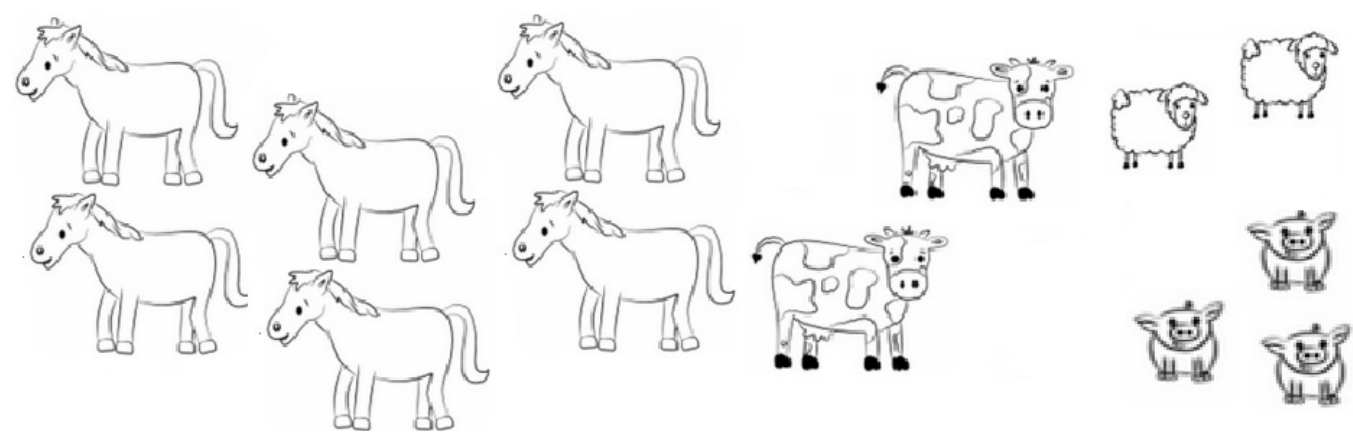

Figura 54. Representació d'animals de granja amb poques vaques i molts cavalls 
Quan el nombre de vaques i el de cavalls és bastant semblant, es pot representar una correspondència biunívoca entre els dos conjunts per ajudar-los a esbrinar que hi ha més cavalls que vaques, com es veu en la figura 55.
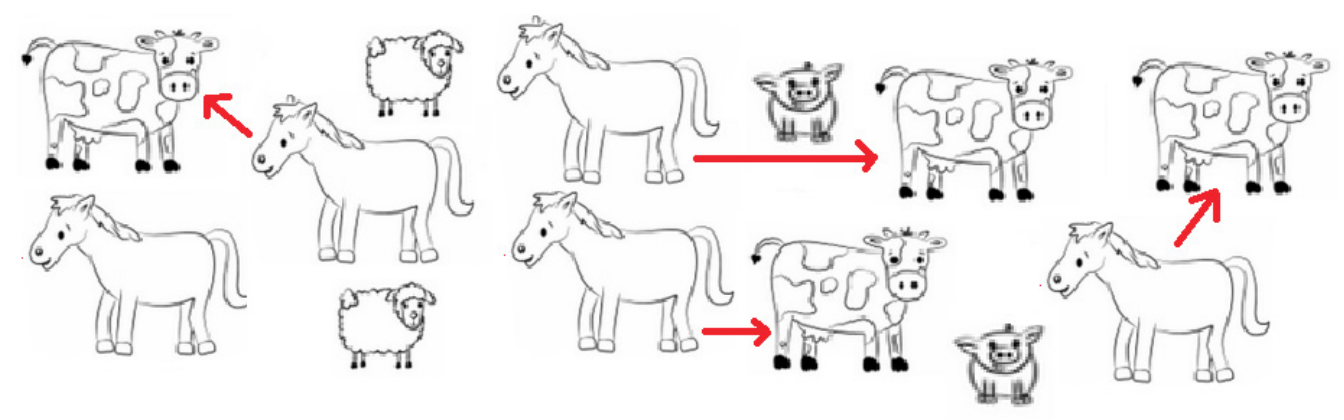

Figura 55. Representació d'una correspondència biunívoca entre el conjunt de cavalls $i$ el de vaques

Cap al final del cicle, repassarem tot el que s'ha vist prèviament i s'augmentarà la dificultat de les activitats, comparant quantitats d'elements, els quals podran ser totalment diferents, amb la finalitat d'aïllar la idea de quantitat de qualsevol altra característica física dels objectes. En aquest moment final del cicle, i si l'alumnat no domina els nombres, és quan es fan més necessàries les comprovacions mitjançant correspondències, perquè és quan l'alumnat tendeix a confondre més les situacions de comparança.

Es reforçarà el domini del vocabulari adient i del treball gràfic esmentat anteriorment.

\section{Conèixer els deu primers nombres naturals a partir de l'experiència amb conjunts d'objectes}

L'objectiu d'aquesta capacitat és matisar la percepció aproximada de la quantitat introduint els nombres per a precisar-la. Per tal de construir-ne cadascun utilitzarem sempre el procediment següent: afegir un element a la quantitat corresponent al nombre anterior al qual volem introduir i presentar el nou nombre associant-lo a la quantitat que acabem de formar.

Abans de començar el 2n cicle d'educació infantil, els xiquets i les xiquetes són ja capaços de distingir entre l'1 i el 2 a partir de l'observació del seu propi esquema corporal i de les preguntes quotidianes al voltant de la seua edat que representen amb els dits. També és probable que troben aquests nombres en objectes aliens al seu propi cos, tenint en compte que 2 serà la quantitat que resulta quan afegim un element a un altre que ja teníem. A mesura que realitzem activitats d'aquest tipus, els nens i les nenes identifiquen les paraules un i dos, associant-les a les quantitats d'objectes corresponents, sense que siga necessària la identificació de les grafies. 
Al principi d'aquest cicle caldrà repassar l'1 i el 2 i introduir el 3 com el nombre corresponent a la quantitat que resulta quan hi afegim un nou element a dos que ja en teníem (tens dos anys i vas a fer-ne un més, és a dir, tres; éreu dos infants pintant el mural i us hi ajuda un altre, ara en sou tres; ...). Per tal de reforçar aquesta idea, comptarem fins a tres objectes reals, evitant la recitació cantada dels nombres descontextualitzats (comptar les fotos dels dos o tres companys que falten avui a classe perquè es troben malalts, comptar els tres colors amb què pintarem un dibuix ...). A més de comptar hauran de construir conjunts de tres elements (formar un grup de tres xiquetes, per exemple; treure tres carpetes de la prestatgeria; ...), fer sèries de mòdul fins a tres elements... (vegeu capacitat 14 del tema 1), sempre de manera manipulativa. Ens assegurarem que l'alumnat domina les paraules que anomenen els nombres coneguts fins ara i la seua correcta associació amb les quantitats corresponents. Tanmateix, introduirem les grafies 1, 2 i 3 sense que siga necessari que les hagen d'escriure en aquest moment. Podem tenir-les penjades en les parets de l'aula, observar-les en el calendari, en les dates de la pissarra, en la llista de classe. També podrien omplir amb gomets les seues siluetes buides i grans, com s'indica en la figura 56, en la qual l'1 està completat, el 2 iniciat i el 3 encara buit, o caminar per damunt d'elles...
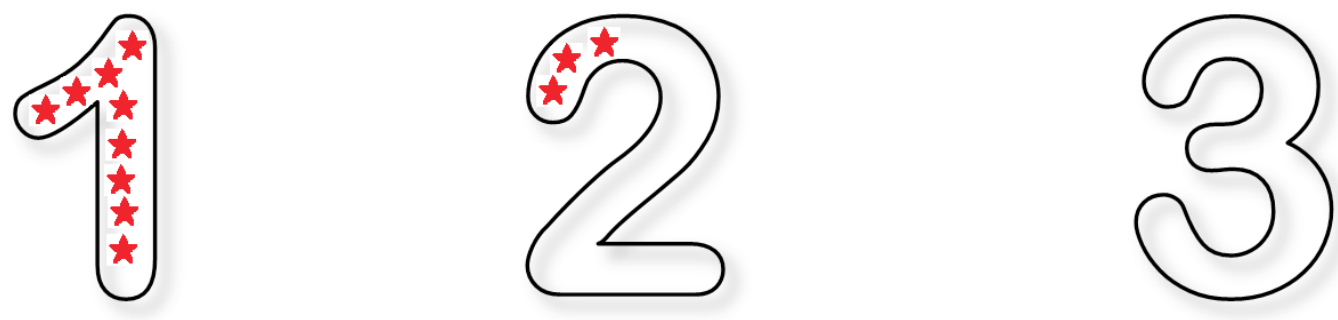

Figura 56. Representació de les siluetes de l'1, el 2 i el 3

A la meitat del cicle repassarem aquests tres nombres i introduirem el 4 i el 5 afegint sempre un element a la quantitat del nombre anterior. Per tal de reforçar aquests nombres nous usarem el seguit anterior d'activitats arribant fins al 5: comptar objectes reals, construir conjunts i completar sèries. Caldrà ampliar aquestes activitats manipulatives amb el comptatge i la construcció de conjunts amb suport gràfic (comptar els 5 cavalls d'una foto d'una granja, per exemple la de la figura 55, comptar els 4 cotxes d'un catàleg de joguines, dibuixar 4 estrelles en un cel pintat...).

També s'haurà de treballar l'escriptura de les grafies dels nombres per part de l'alumnat, tenint en compte les limitacions que poden presentar associades al seu nivell d'orientació espacial i de lateralitat, a més del grau de desenvolupament de la seua motricitat fina.

Abans de continuar amb més nombres, introduirem el zero, per indicar quan no hi ha cap element.

El zero no és el primer nombre en introduir-se i aquest fet té una explicació. És la manera de representar el contrari del que representen la resta de nombres. 
És l'únic que es refereix a l'absència de quantitat, per això no podem pensar que el tractament és igual. Cal dir també que ha estat un fet històricament difícil de conciliar amb els diferents sistemes de numeració. Encara que la humanitat ha utilitzat el zero per representar l'absència d'elements des de fa més de 4.000 anys en la civilització babilònica, aquest no es va usar per ocupar un lloc en la representació dels nombres de diverses xifres fins que els indis l'incorporaren al seu sistema de numeració aproximadament al segle v. Cal triar bé situacions que originen la necessitat de representar que no hi ha cap element d'algun tipus per tal de justificar la seua aparició. Per exemple, la puntuació d'un alumne en un quadre que arreplega els resultats d'un joc, el nombre de xiquets i xiquetes que estan malalts un determinat dia en un llistat de faltes de cada mes, el nombre de germans d'alguns nens, etc.

Més endavant, per completar l'estudi dels nombres en educació infantil s'introdueixen el 6,7, 8 i 9, sempre pel procediment d'afegir un element a la quantitat que correspon al nombre anterior. S'usarà el mateix esquema de treball que s'ha seguit pels altres nombres: comptar fins a 6, 7, 8 o 9 objectes, construir conjunts que tinguen aquests nombres com a cardinals i completar sèries de mòdul fins a 9 elements, mitjançant activitats que estaran relacionades amb situacions d'interés per a l'alumnat i que es realitzaran tant de manera manipulativa com amb suport gràfic (comptar o construir conjunts a partir de revistes, catàlegs, fotografies, llibres, dibuixos...). Per exemple, si estem treballant un projecte en classe sobre Egipte, els podem presentar diferents il·lustracions (figura 57), perquè compten els elements que hi apareixen.
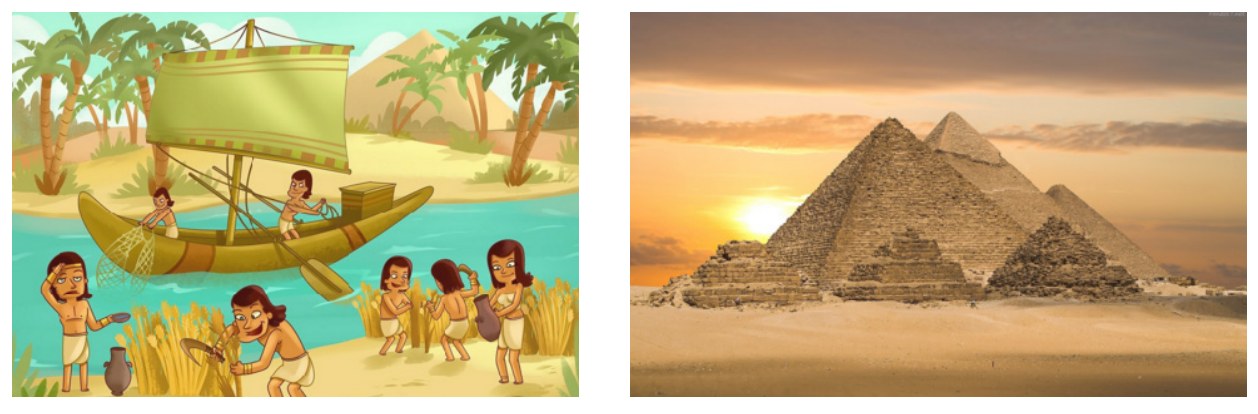

Figura 57. Imatges d'Egipte per a comptar persones (esquerra) i piràmides (dreta)

Es reconeixen les noves grafies i es reforça la representació gràfica d'aquestes i de les anteriors, sabent que cap al final de l'etapa ha millorat prou el nivell d'orientació espacial i de lateralitat de l'alumnat, així com l'evolució de la seua motricitat fina. És important que coneguen altres tipus de grafies a més de les que s'utilitzen en la classe, per diversificar i enriquir el seu coneixement (buscar representacions dels nombres en llibres, calendaris, cartells i observar les seues semblances i diferències).

Caldrà treballar també l'estimació de quantitats d'elements a cop d'ull, per ajudar a aconseguir que es fixen en la quantitat i no en la grandària, la forma, el color, etc., dels objectes, potenciant d'aquesta manera el desenvolupament del seu sentit numèric. En qualsevol activitat en l'escola ens trobem amb agrupacions d'elements, 
per exemple, quan van a classe de psicomotricitat podem tenir preparats diferents pilots de materials per utilitzar-los: un amb 3 pilotes, un altre amb 5 pals i un altre amb 7 cons. Es tracta d'identificar, per exemple, el nombre de pals sense que siga necessari comptar els elements.

\section{Formar i reconèixer conjunts que tinguen el mateix nombre d'elements que un donat}

A mesura que l'alumnat va coneixent els nombres, caldrà desenvolupar estratègies per tal de reforçar la seua funció cardinal. Això passarà per afermar la idea de nombre d'un conjunt, fins que aquesta quede assolida suficientment i, amb ella, els xiquets i les xiquetes assimilen l'aspecte cardinal dels nombres naturals.

En la segona part del cicle, i tenint en compte que usarem els nombres que coneguen en cada moment, caldrà que formen conjunts amb el mateix cardinal que un altre donat. Haurem d'insistir en què els elements poden ser diferents als del model, només caldrà que el conjunt tinga el mateix cardinal. Per exemple, si estem preparant la taula per fer un berenar d'aniversari, posem cinc plats en la taula principal, al costat de la qual hi ha una altra amb gots i culleres (figura 58).
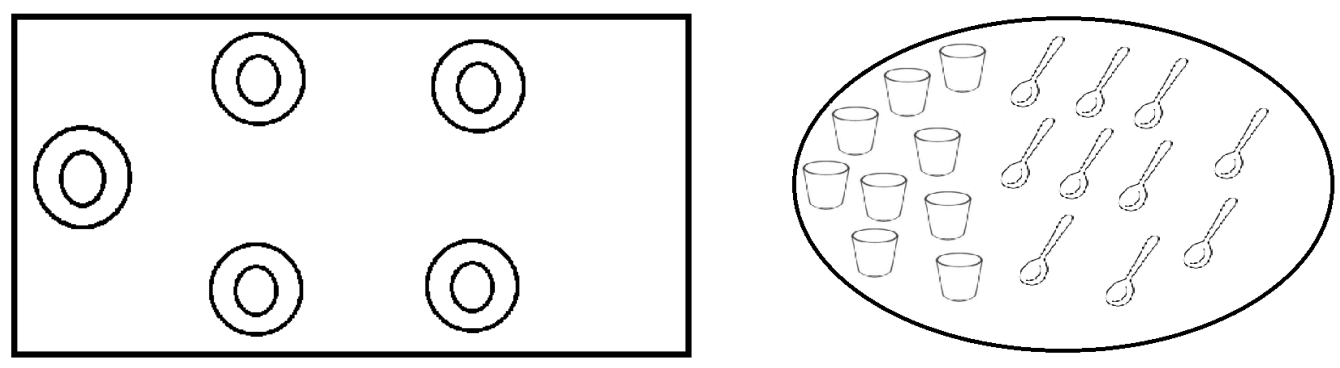

Figura 58. Representació d'una taula amb 5 plats i d'una altra amb gots i culleres

Els xiquets i les xiquetes hauran d'acabar de parar taula formant conjunts de tants gots o de tantes culleres com plats hi ha.

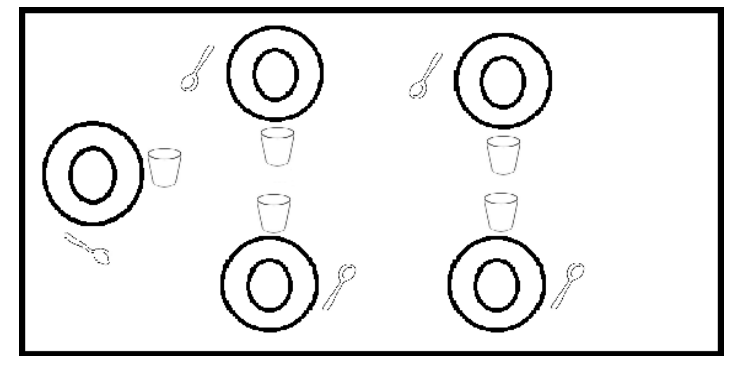

Figura 59. Representació d'una taula amb conjunts equipotents de plats, gots i culleres

Una vegada estiga creat el nou conjunt, és important preguntar-los quants elements hi havia en el primer i quants n'hi ha en el que han format. En aquest moment la força ha de recaure en la comprovació de la igualtat dels cardinals i en la 
seua correcta verbalització: "Hi ha igual quantitat de gots (o de culleres) que de plats», «n'hi ha 5 de cada», per exemple.

Si el que es vol és reconèixer la igualtat de cardinals entre un conjunt donat $\mathrm{i}$ un altre que han de seleccionar, l'alumnat triarà, entre diversos conjunts amb diferents quantitats d'elements, algun el cardinal del qual siga igual que el del primer. Per exemple, hem triat un grup de sis xiquets i xiquetes per fer un ball i tenim diverses caixes amb cintes de colors que han d'utilitzar en el ball; es tracta que seleccionen la caixa que té el mateix nombre de cintes que d'alumnes. Cal preguntar-los «quin és el motiu que els ha fet agafar eixe conjunt» i els demanarem que verbalitzen la igualtat de quantitats i la igualtat numèrica de manera anàloga al cas anterior, és a dir, «hi ha igual quantitat de nens i nenes que de cintes», «n'hi ha 6 de cada», per exemple. En un primer moment sols hi haurà un conjunt que complirà la condició i, més endavant, pot haver-hi més d'un per a triar.

Tant en el cas de formar conjunts com en el de reconèixer-los es pot treballar al principi amb objectes reals i més endavant amb representacions gràfiques, realitzades tant pel mateix alumnat com preparades pels docents. En qualsevol dels casos hauran de fixar-se en la quantitat d'elements del conjunt inicial i del conjunt format o triat i verbalitzar la igualtat dels seus cardinals reforçant-la amb la utilització del nombre comú.

\section{Classificar conjunts segons el seu cardinal}

El que es pretén amb aquesta capacitat és comprovar si els xiquets i les xiquetes tenen interioritzada la idea de quantitat associada al concepte de nombre i si són capaços de considerar-la com una propietat dels elements d'alguns conjunts que els permet classificar-los.

Es començarà el darrer curs del cicle perquè es tracta d'aprofundir en el coneixement dels conceptes de quantitat i nombre, per a aconseguir que l'alumnat els integre de manera natural en el seu pensament, ja que són dos conceptes que sempre estan presents en la realitat.

Podem desenvolupar aquest treball a partir d'un material preparat, buscat o construït per nosaltres mateixos en el qual, junt amb qualitats com colors, formes, etc., aparega també la quantitat com una més de les característiques de les peces que el componen. Per exemple, preparem 24 bosses i 24 gots de plàstic transparent amb 3, 4 o 5 caramels del mateix tipus (amb pal o sense pal) i del mateix sabor (maduixa, taronja, llima i menta) en cada recipient. Caldrà que ho classifiquen de totes les maneres possibles que se'ls puga ocórrer a partir de les nostres propostes de guardar el material en quatre, dos o tres caixes.

En un primer moment el criteri triat per tal de fer les classificacions serà el sabor (quatre classes, una en cadascuna de les quatre caixes), el tipus de caramel o el de recipient (dues classes, una en cada caixa). Posteriorment, insistint en què 
continuen classificant de maneres diferents a com ja ho han fet, ha d'aparèixer la classificació pels cardinals, és a dir, l'agrupació de tots els envasos que tinguen tres caramels, per un costat, tots els que en tinguen quatre, per altre i tots els que en tinguen cinc, en darrer lloc (tres classes ara, una en cadascuna de les tres caixes).

En aquest moment és quan ja han considerat el cardinal del conjunt com una propietat que pot caracteritzar conjunts $i$, per tant, pot servir com a criteri per a classificar el conjunt referencial. S'ha produït de manera natural l'associació quantitat i nombre, per tant s'ha identificat el nombre amb la quantitat que li correspon.

En les classificacions anteriors podem posar nom a cadascuna de les classes que es formen: amb pal, sense pal; els de llima, els de maduixa, els de taronja, els de menta; les bosses, els gots. Procedirem de manera anàloga en la darrera classificació; així, el nom que correspon a la classe formada per tots els envasos de tres caramels podria ser «els de $3 »$, «els de 4» seria el nom de la classe formada pels envasos amb quatre caramels $\mathrm{i}$ «els de 5 » el de la formada pels de cinc caramels. Cal adonar-se que estem fent ús de la definició formal de nombre natural segons Cantor (vegeu la «Introducció» d'aquest tema) i que les classes obtingudes en la darrera classificació s'han construit en aplicar la relació binària d'equivalència «tenir el mateix cardinal». Serà doncs, en aquest cas, el nombre natural allò que caracteritza cadascun dels conjunts classificats.

També és convenient que miren al seu voltant i troben situacions en les quals es classifiquen conjunts pel seu cardinal: envasos per a ous (figura 60), caixes de llapis de colors, de gomes d'esborrar, paquets de fulls, etc.

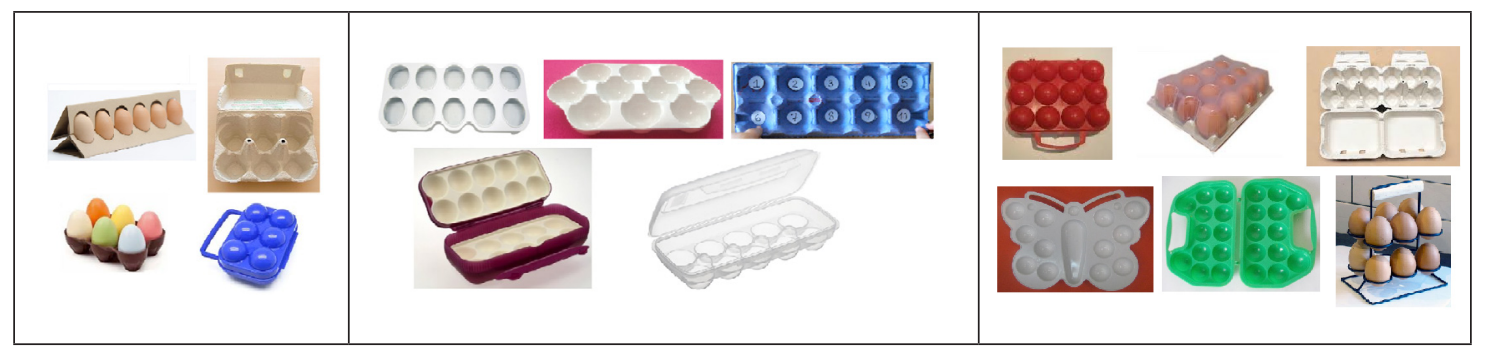

Figura 60. Classificació d'envasos per a 6, 10 o 12 ous

Més endavant treballarem aquesta capacitat utilitzant materials gràfics en els quals aparega el cardinal com una de les seues característiques. Per exemple, relacionat amb un treball a l'aula sobre el camp, podem fabricar un material compost per fitxes de cartolina amb dibuixos de flors, arbres i bolets, de tres colors diferents $\mathrm{i}$ amb dos, tres o quatre dibuixos en cada fitxa (figura 61). 


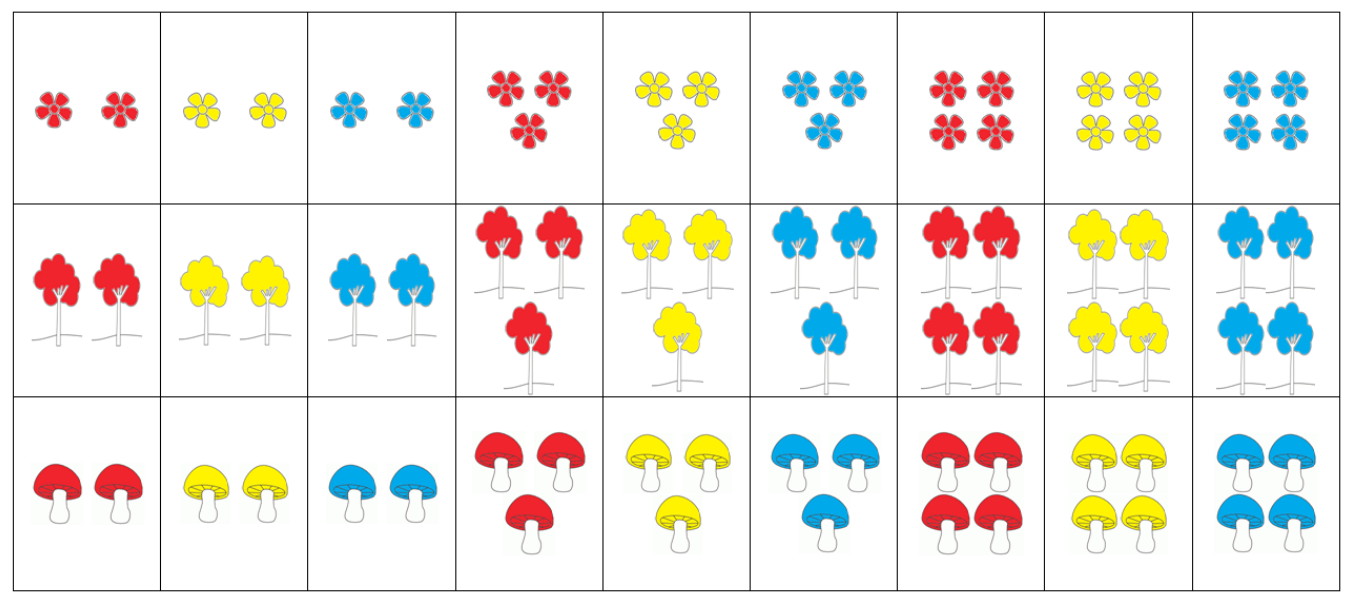

Figura 61. Exemple de material gràfic per a treballar la classificació pel cardinal

Poden classificar-les per colors i per figures de manera prou fàcil. El nostre interés serà que ho facen també pel nombre de dibuixos de cada fitxa, per arribar a les mateixes finalitats que al casos anteriors.

És imprescindible que l'alumnat verbalitze tot el treball que faça amb objectes reals o gràfics i que expresse correctament les relacions que s'estableixen entre les diferents peces dels materials i les igualtats numèriques que es tenen en compte per a establir les classes d'equivalència.

\section{Formar i reconèixer conjunts que tinguen més o menys elements que un donat. Comparar els cardinals dels conjunts}

Com a complement de la capacitat 4 i avançant en el coneixement dels dos aspectes dels nombres naturals, cal treballar ara la seua funció ordinal i seran aquesta capacitat i la següent les encarregades de fer-ho. Els conjunts continuaran sent els instruments que usarem per tal de treballar-les.

També en la segona part del cicle i tenint en compte els nombres que l'alumnat coneix en cada moment, caldrà que formen conjunts amb més o menys elements que un altre donat. Haurem d'insistir en què els elements poden ser diferents als del model, només caldrà que el nou conjunt tinga més o menys elements que aquell. Per exemple, si hem triat un grup de quatre alumnes per a preparar un mural, podem demanar-los que traguen de l'armari del material d'aula més o menys cartolines que xiquets i xiquetes són per a treballar amb elles. Quan estiga creat el nou conjunt els preguntarem quants elements hi havia en el primer conjunt $i$ quants n'hi ha en el que han format. En aquest moment la força ha de recaure en la comprovació de la desigualtat dels cardinals i en la seua correcta verbalització: hi ha més o menys quantitat de cartolines que de xiquets $i$ xiquetes, hi ha cinc o tres cartolines i quatre xiquetes, per exemple. En qualsevol dels casos, hauran de completar la verbalització expressant la comparació entre els nombres utilitzant el vocabulari correcte: cinc és major que quatre o tres és menor que quatre. 
Si el que es vol és reconèixer la diferència de cardinals entre conjunts, l'alumnat haurà de trobar, a partir d'un conjunt model i de diversos de distints cardinals, algun amb més o menys elements que el primer. Per exemple, hem posat en una taula cinc plats buits per a preparar un berenar i tenim unes caixes amb diferents quantitats de bosses de papes (3), d'ametles (2), de cacaus (7), de potets d'olives (4), etc.; es tracta que troben quina és la caixa que té més o menys bosses o potets, que plats hi ha. Cal preguntar-los «quin és el motiu que els ha fet agafar eixe conjunt» $\mathrm{i}$ demanar-los que verbalitzen la diferència de quantitats i la desigualtat numèrica de manera anàloga al cas anterior, per exemple, hem triat la caixa que té set bosses de cacaus perquè hi ha més bosses que plats, o hem triat la caixa que té tres bosses de papes perquè hi ha menys bosses que plats. Les expressions de les comparacions numèriques seran ara, respectivament, 7 és major que 5 o bé 3 és menor que 5. En un primer moment sols hi haurà un conjunt que complirà la condició i, més endavant, pot haver-hi més d'un.

Per realitzar totes aquestes activitats es pot treballar primer amb objectes reals i després amb representacions gràfiques, sense oblidar que sempre han de fixar-se en la quantitat d'elements del conjunt inicial i del conjunt format o triat. Per exemple, en un projecte sobre l'univers volem que els xiquets i les xiquetes dibuixen trajectòries que diferents coets espacials recorren per anar d'uns planetes a uns altres. Els oferim la representació d'un conjunt amb tres coets i els demanem que dibuixen més planetes que coets hi ha per poder elaborar distints murals amb les esmentades trajectòries (figura 62).
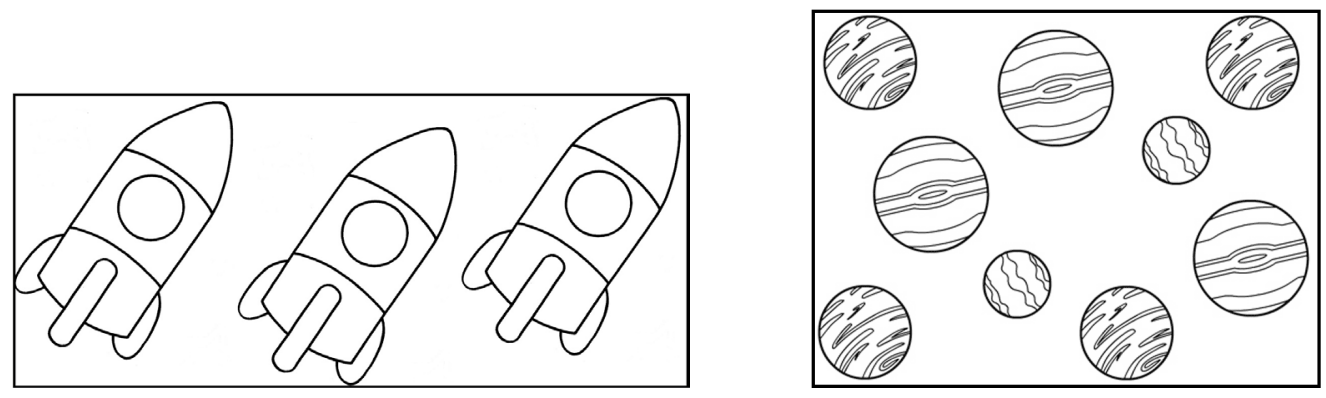

Figura 62. Representació d'un conjunt amb tres coets espacials i d'un altre amb nou planetes dibuixats per l'alumnat

És imprescindible arribar sempre a expressar adequadament la desigualtat entre els cardinals dels dos conjunts i, per tant, el seu ordre.

En el desenvolupament d'aquesta capacitat hem de reconèixer dos nivells d'aproximació als nombres. Primerament, en observar els conjunts, cal comparar la quantitat d'elements que hi ha, fixant-se només en ells. Després, es fixaran en els nombres que simbolitzen els cardinals, els compararan i, recordant les quantitats que representen, els ordenaran. Aquesta serà l'acció que buscàvem ara, ordenar dos nombres comparant cardinals de conjunts. 
7. Ordenar conjunts segons el seu cardinal i ordenar els cardinals d'aquests conjunts. Comptar progressivament $i$ regressivament

Com a complement de la capacitat anterior i amb la intenció d'ordenar tota la sèrie numèrica que es treballa en educació infantil, es pretén ara ordenar més de dos conjunts en funció del seu cardinal i, per tant, ordenar més de dos nombres. Continuarem reproduint el mateix procés de comparació, però amb la dificultat afegida de treballar amb més conjunts.

Es començarà comparant les quantitats d'elements de tres conjunts que poden o no correspondre a nombres consecutius i, després de verbalitzar les seus desigualtats, s'arribarà a l'expressió de l'ordre entre els nombres implicats. Per exemple, si en la cistella on deixen els seus esmorzars tenim dos entrepans de paté, quatre de tonyina i sis de pernil dolç, ordenaran els conjunts corresponents i verbalitzaran: $h i$ ha menys entrepans de paté que de tonyina i menys de tonyina que de pernil dolç, per poder dir a continuació que dos és menor que quatre i quatre és menor que sis. Evidentment, també es podria realitzar la comparació inversa i ordenar així els nombres de major a menor.

Aquestes situacions, que treballarem primerament amb objectes reals i després amb representacions gràfiques, aniran complicant-se en la segona meitat del cicle fins que puguen arribar a ordenar nou conjunts i, amb ells, els nou nombres associats.

És important que completem aquestes activitats amb altres en les quals siga necessari comptar ordenadament diferents quantitats d'objectes per ajudar-los a fixar l'ordenació dels nombres de manera natural en el seu pensament. Podem ajudar-nos de jocs o cançons (Els elefants en la tela de l'aranya, Les pometes del pomer, La cançó de les ampolles, John Brown era un petit indi...) en les quals el comptatge es realitze tant progressivament com regressiva, acompanyant-lo de la representació real d'allò que estan cantant (xiquets i xiquetes que fan d'elefants, pilotes que simulen pomes que es lleven $\mathrm{i}$ es posen d'un pomer...), perquè no es tracta sols de recitar els nombres sense més, sinó d'associar-los a la quantitat d'objectes que els correspon.

\section{Expressar nombres ordinals en la seua numeració especifica}

En aquesta capacitat es pretén que l'alumnat conega els noms i les representacions dels nombres ordinals, associant-los amb els cardinals corresponents, en diferents accions quotidianes que ho justifiquen.

Es tracta d'introduir, sobretot en el darrer curs de l'etapa, les paraules primer, segon, etc., relacionant-les amb les posicions en una fila, l'arribada en una cursa, els passos a seguir per fer un dibuix, una recepta de cuina..., i també d'utilitzar les formes escrites $1 r, 2 n$, etc., per a representar-les. 
L'objectiu que ens marquem en el desenvolupament d'aquesta capacitat és que els xiquets $i$ les xiquetes observen la presència quasi constant dels nombres en la seua vida i que reconeguen la seua utilitat en qualsevol situació quotidiana.

La treballarem principalment en el darrer curs d'educació infantil a partir de conversacions entre ells i elles, lectures de diferents textos, explicacions de distintes situacions tant de la vida diària com de les que es realitzen en classe..., per fer-los reflexionar al voltant del moment en què apareixen els nombres i quina és la seua importància en cada cas. Com a activitat complementària els podem convidar a intentar viure un matí a l'aula sense utilitzar cap nombre, per tal que s'adonen de la dificultat que suposaria la seua omissió. 


\section{TEMA 3}

\section{Càlcul operacional \\ en l'educació infantil}

\section{Introducció}

En aquest tema es treballa la iniciació a l'aritmètica, per oferir als xiquets i les xiquetes les eines matemàtiques que els ajuden a respondre les preguntes que la realitat els planteja respecte a «quants n'hi havia?, què hi ha passat?, quants en queden?».

Comença amb la proposta de quatre fases per treballar les operacions a l'escola i finalitza amb el tractament didàctic de les primeres relacions de l'alumnat amb l'addició i la subtracció.

\subsection{Reflexió general sobre les operacions a l'escola}

Sembla lògic pensar que l'immediat, una vegada s'ha introduït el concepte de nombre, hauria de ser el treball d'operar amb nombres naturals i signes aritmètics. Però aquesta tasca requereix un nivell d'abstracció superior al que cal per a analitzar adequadament les accions amb objectes, que són més intuïtives i que l'alumnat no les trobarà a l'escola per primera vegada.

Es pot afirmar, doncs, que hi ha dos tipus de situacions en referència amb el fet «d'operar». Unes serien extraescolars, per tant, naturals, intuïtives i sovint necessàries. Aquestes accions es podrien anomenar també càlcul mental, pel fet que no s'ha de disposar en el moment de llapis i paper. Les altres són les escolars, on molts dels esforços s'encaminen a esbrinar mecanismes o a memoritzar algorismes (conjunt sistemàtic de passos que condueixen a l'obtenció d'un resultat) que permeten operar. Dues situacions ben diferents a priori i amb una resposta també ben diferent per part de l'alumnat.

L'escola, d'una banda, ha de solucionar aquesta situació de dicotomia; de l'altra, deu ser el lloc on es canalitze i respecte l'aprenentatge que els xiquets i les xiquetes fan fora de l'aula. Alhora ha d'afavorir que aquest s'integre en el coneixement o «reconeixement» de les operacions aritmètiques que cal desenvolupar a classe. I, és clar, l'objectiu és dotar l'alumnat de més eines, de més capacitats per tal de resoldre els nous problemes que la realitat els planteja. Per tant, el procediment se simplifica d'aquesta manera: cal partir de situacions problemàtiques de la realitat 
i treballar les eines necessàries per solucionar-les, dotant-los així de les capacitats matemàtiques que, una vegada assolides, els permetran resoldre noves situacions reals. En l'etapa d'educació infantil treballarem sols a partir de situacions quotidianes. En primària avançarem des de les situacions reals cap a les abstraccions, la reflexió sobre les operacions i els mecanismes de càlcul.

L'objectiu de l'escola, doncs, estarà cobert quan el xiquet o la xiqueta que siga capaç d'operar amb signes matemàtics reconega l'íntima relació que hi ha entre les accions extraescolars i les escolars, descobrint així que està preparat per donar resposta matemàtica a les situacions de la seua vida quotidiana. Cal esmentar que la realitat de vegades és ben diferent i l'aprenentatge escolar no garanteix l'eliminació dels entrebancs entre aquests dos tipus de situacions. El repte serà aleshores, trobar la manera d'apropar als ulls de l'alumnat els procediments que els permetran operar i que tradicionalment han pogut ser algorismes foscos allunyats de la intuïció.

En tot el treball escolar referent al càlcul operacional presentarem les operacions seguint un esquema amb les fases següents:

1. Exposar el significat de l'operació partint d'experiències de la realitat i de la seua relació amb la Teoria de Conjunts, perquè l'operació tinga sentit per a l'alumnat.

2. Traduir simbòlicament l'operació.

3. Automatitzar l'operació. Conèixer l'algorisme, saber utilitzar-lo.

4. Resoldre i inventar situacions problemàtiques relacionades amb l'operació.

Quan treballem aquestes fases, l'expressió numèrica de l'operació serà la transcripció de les manipulacions dels xiquets i les xiquetes. Cal tenir en compte la dificultat que suposa per a l'alumnat passar d'una acció concreta amb els objectes a la seua expressió simbòlica. Per exemple, entre la situació de reunir un conjunt de tres pomes i un altre de sis, i l'expressió $3+6$, s'han de salvar una sèrie de dificultats a causa dels significats diferents que tenen per a ells les dues accions. La utilització de signes matemàtics per a escriure les operacions, per a simbolitzar-les, exigeix una preparació prèvia mitjançant algunes etapes successives. En primer lloc, repetirem la manipulació amb els objectes les vegades que ho considerem necessari. Al mateix temps, treballarem la translació al llenguatge verbal demanant-los que ens conten què han fet, les seues reflexions, els seus pensaments. Superat aquest moment, podem introduir el pas al llenguatge gràfic i a la expressió mitjançant símbols i signes matemàtics. El problema del docent és aconseguir que l'alumnat siga capaç de relacionar les accions reals o imaginades amb la seua traducció al llenguatge matemàtic, que utilitza els seus signes propis i les seues fórmules. No es tracta, doncs, de fer comprendre als xiquets i les xiquetes el significat de l'operació després d'haver-los ensenyat a calcular-la, sinó al contrari, cal que utilitzen una operació en la mesura que comprenen el que aquesta expressa i significa. Alhora hem de treballar la reversibilitat del seu pensament respecte a les operacions, és a dir, cal que l'alumnat siga capaç de pensar en situacions reals que es resolguen utilitzant les diferents operacions estudiades. 


\section{El càlcul operacional a l'aula d'infantil}

\subsection{Consideracions prèvies}

De la mateixa manera que al nostre voltant sempre està present la idea de quantificar la realitat i la seua expressió provoca la presència constant dels nombres en qualsevol acció o relació que establim, la idea de càlcul està també present i íntimament unida al concepte de nombre natural.

Per tal d'operar és necessari un coneixement ampli del Sistema de Numeració Decimal (SND) i el fet d'obtenir un resultat en aplicar una operació mitjançant un algorisme, exigeix també un desenvolupament cognitiu que en la majoria de casos sobrepassa les edats que corresponen a l'educació infantil.

Per tant, si la pregunta és si s'opera en aquesta etapa educativa a l'estil proposat en el paràgraf anterior, la resposta és no. Però ¿vol dir això que a l'educació infantil no hi ha activitat mental que es pot relacionar amb càlcul operacional? Rotundament, també, la resposta és no.

Serà doncs, aquest tema, $i$ en concret les quatre capacitats dedicades al segon cicle d'educació infantil, l'encarregat de posar els primers passos en aquesta nova manera de pensar, que combina els representants de les quantitats, els nombres, per tal d'obtenir-ne altres que formen part de les solucions de les situacions problemàtiques que es plantejaran a l'aula per a contextualitzar la nostra tasca docent i trobar l'interés d'ells i elles en allò que operen.

El nostre objectiu serà tractar d'una manera interessant i amb molta implicació dels xiquets $i$ les xiquetes aquestes primeres aproximacions al que significa operar, evitant l'avanç de processos que poden anguniar-los o predisposar-los de manera negativa cap a les matemàtiques i que amb la maduració cognitiva natural, és a dir, fent-ho en el moment oportú, no suposaria cap entrebanc. Evidentment en l'etapa d'educació infantil sols treballarem les dues primeres fases de les operacions i amb un nivell molt incipient.

No serà, doncs, el nostre objectiu demostrar tot el que sap l'alumnat d'infantil si, quan passen a educació primària, ja operen de manera bàsica. Serà guiar el seu procés d'adquisició matemàtica de la manera més respectuosa amb el seu nivell de desenvolupament i estimular totes les seues capacitats per tal de dotar-los de les eines que els permetran fer, en el seu moment, les progressions matemàtiques que ara no hem treballat de forma explícita, però sí d'una manera implícita per tal de propiciar ulteriors èxits. 


\subsection{Capacitats per desenvolupar a l'aula d'infantil}

Com establir els primers passos d'una manera seqüencial i adequada a l'educació infantil respecte del càlcul operacional serà l'objectiu del tema, contribuint a desenvolupar en l'alumnat les capacitats següents:

1. Compondre i descompondre nombres d'una xifra.

2. Resoldre situacions problemàtiques senzilles.

3. Realitzar transformacions que modifiquen i que no modifiquen una quantitat (amb materials separats).

4. Iniciar el càlcul mental.

\subsection{Desenvolupament de les capacitats}

Amb les mateixes consideracions de l'apartat 3.3 del tema 1, estudiarem a continuació els procediments per a construir els primers passos del càlcul operacional a l'aula d'educació infantil.

\section{Compondre i descompondre nombres d'una xifra}

En aquesta capacitat posem la mirada en la quantitat i en algunes situacions en les quals hi roman invariable. Es pot redistribuir o reorganitzar, però no hi haurà cap augment o disminució en ella.

Començarem component $\mathrm{i}$ descomponent diferents quantitats en activitats molt properes i amb nombres petits. Per exemple, per al cas de compondre, podem agrupar damunt la taula de la mestra dues cartolines i una cartolina que hi havia en les taules d'un xiquet i d'una xiqueta de la classe. Per al cas de la descomposició i, per posar-ne un a cada finestra de l'aula, repartirem en dos gerros les tres flors que un xiquet ha dut per a la mestra. En ambdós casos tenim tres objectes tant a l'inici com al final de les activitats, però estan organitzats de formes diferents.

A mesura que avança el $2 \mathrm{n}$ cicle, ampliarem el treball a nombres més grans, encara que seguirem component a partir de dues quantitats inicials i descomponent també en dos conjunts d'objectes. A més, podem iniciar la representació gràfica de situacions d'aquest tipus en les quals utilitzaran dibuixos agrupant o separant els elements de la mateixa manera que es feia manipulativament. Per exemple, retallaran cinc taronges d'un catàleg situant-ne tres en un mural sobre alimentació i dues en un altre sobre productes típics de la Comunitat Valenciana (figura 63) o col-locaran quatre zebres en un tancat reunint-ne una i tres que hi havia en altres dos que apareixen en les imatges d'un zoològic, que s'està treballant a l'aula relacionat amb un projecte globalitzat sobre animals salvatges. 

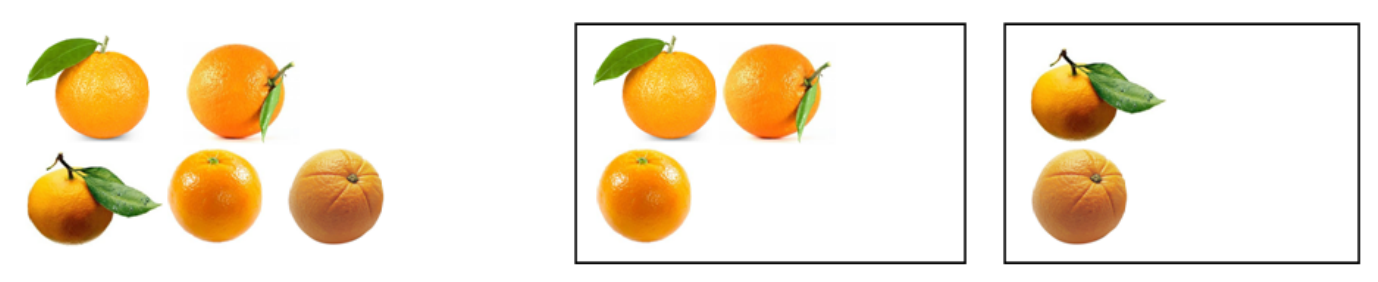

Figura 63. Representació de cinc taronges retallades d'un catàleg i la seua distribució en dos murals

Al darrer curs del cicle es continua fent activitats com les esmentades, però ara s'utilitzen ja tots els nombres que s'estudien en infantil i es pot compondre un nombre a partir de més de dues quantitats inicials i descompondre'l també en més de dos nombres. Com a exemples podem reprendre el de les cartolines, que ara en seran set $i$ estaran inicialment en tres taules, o el de les flors, que en seran vuit $i$ hauran de repartir en tres gerros per a adornar l'aula.

En tots els nivells de treball l'alumnat ha de verbalitzar el que ocorre en cada cas (hi havia tres cartolines separades en dues i una i ara estan les tres juntes, per exemple, per a la primera situació descrita amb cartolines), observant que no varia la quantitat i reflexionant sobre les diferents maneres de distribuir-la (en el cas de vuit elements, dues flors en un gerro, dues en un altre i quatre en un altre o bé, tres flors en un gerro, tres en un altre i dues en un altre o..., per exemple).

\section{Resoldre situacions problemàtiques senzilles}

Ens interessen ara situacions en les quals la quantitat es veu modificada, perquè afegim o llevem elements. No es pretén arribar al fons de les operacions, encara que les accions d'afegir o llevar estan en la seua base. El que volem és potenciar en l'alumnat un pensament d'anticipació i reflexió a partir d'una modificació de la quantitat d'elements inicials.

Des del principi del cicle i començant amb els primers nombres, buscarem situacions d'afegir o llevar quantitats interessant-nos per tot el que ocorre en elles. Per exemple, la mestra de la classe ha comprat tres barres de pa per fer berenars, la de la classe del costat n'ha portat dues més i ens preguntem quantes barres tenim en total. Cal que acompanyem el procés manipulatiu amb la seua verbalització, insistint en la situació inicial, la transformació que ha sofert la quantitat i la situació final. És a dir, hem de fer-los conscients de quants n'hi havia al principi, de què ha passat i de quants en queden al final. En el cas de les barres de pa diran «teníem tres barres de pa, la mestra del costat n'ha dut dues més i ara en tenim cinc».

Anirem augmentant els nombres que utilitzen per a aquestes situacions i introduirem activitats gràfiques en les quals els xiquets i les xiquetes representen amb dibuixos l'augment o disminució de la quantitat per l'efecte d'afegir o llevar elements als que hi havia dibuixats al principi. Per exemple, hi ha dibuixades quatre llunes i en fan falta dues més o hi ha sis llunes i en retallen dues. 
Per desenvolupar aquesta capacitat i a més d'activitats com les que acabem d'esmentar que podem trobar en el dia a dia de l'alumnat, ens podem ajudar de situacions de compra venda escenificades a l'aula. Són molt motivadores i proporcionen una estupenda ocasió per a treballar activitats d'afegir i de llevar elements amb nombres senzills. Utilitzarem monedes de valor 1 (euro, cèntim o qualsevol altra) perquè no ens interessa ara que aprenguen el sistema monetari, només que usen les monedes per a propiciar l'intercanvi entre ells i les situacions d'augment i de disminució de la quantitat que es produeixen.

En la primera part del $2 \mathrm{n}$ cicle d'infantil manipularan una quantitat de monedes no superior a cinc, compraran sols un producte (el preu del qual no serà superior a cinc monedes) i serà la mestra o el mestre qui farà de botiguer/a. S'escenificarà el que seria el procés de compra-venda a l'aula i es verbalitzarà el que ocorre, prestant especial atenció als tres moments esmentats abans: situació inicial, transformació i situació final. Cal que siguen conscients dels diners amb què compten a l'inici. Que ho verbalitzen i que tinguen clar què tenen. En el pas següent, i en relació amb les transformacions, es trobaran dos tipus de situacions diferents: quan van a demanar diners al docent perquè no en tenen prou o quan van a comprar. En els dos casos estem modificant la quantitat. Quan en demanen, reben unes monedes que augmenten les que tenien i quan van a comprar han de pagar uns diners i, per tant, al final en tenen menys. En ambdós casos han d'acabar dient allò que els ha quedat al final: «Tenia una moneda i me n'han donat dues més, ara en tinc tres» o «Tenia quatre monedes i n'he gastat tres, me'n queda una». Cal insistir en la importància d'estimar el resultat de les seues accions per esbrinar si poden comprar o no un producte amb uns determinats diners o si han pagat bé i els queda el que esperaven.

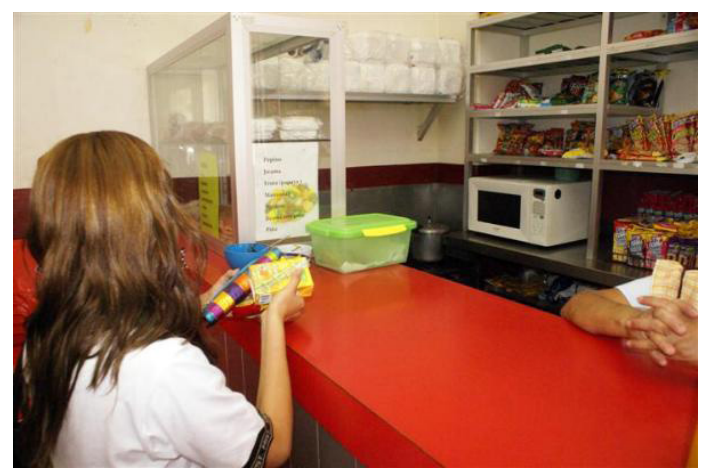

Figura 64. Imatge d'una tenda escolar

Més endavant organitzarem els prestatges en què es troben els productes de la tenda de manera que, comprant un de cada prestatge, no se supere la quantitat major de monedes que estiguen utilitzant (per exemple, en un prestatge, 1lepolies, el preu de les quals arriba fins a tres monedes i, en l'altre, refrescs que poden valer-ne fins a dues). L'alumnat prepararà les monedes que corresponen als dos productes i verbalitzarà el que ocorre en aquestes compres. Per exemple, «He preparat quatre monedes per pagar-ne dues que val una bossa de caramels i dues que val una ampolla d'aigua». 
A l'últim curs, els compradors podran tenir fins a nou monedes i les situacions continuaran sent d'afegir o de llevar de manera anàloga a les esmentades abans. La novetat és que ara els mateixos alumnes poden ser els venedors i que es pot introduir la realització de la llista de la compra per part dels xiquets i les xiquetes que van a comprar dos productes i del tiquet de venda per part dels que actuen com a venedors. En els dos casos escriuran els noms dels productes i els seus preus respectius, així com el preu final, que poden calcular reunint les monedes de cada producte o dibuixant les monedes respectives al costat de cada nombre i comptant-les totes juntes, com es pot veure, en forma d'exemple, en la figura 65.

\begin{tabular}{|l|l|}
\hline PAS 1 & PAS 2 \\
\hline CARAMELS 2 & CARAMELS 2 \\
XICLETS 3 & XICLETS 3 \\
TOTAL ? & TOTAL ? \\
\hline PAS 3 & PAS 4 \\
\hline CACLETS 3 & CARAMELS 2 \\
\hline TOTAL & TOTAL 5
\end{tabular}

Figura 65. Representació del càlcul manipulatiu i numèric del preu d'una compra de dos productes

Per portar la seua comptabilitat i comprovar els diners que els queden després de fer una compra, poden fer els càlculs necessaris amb les monedes reals o amb els seus dibuixos, com es veu en la figura 66. 


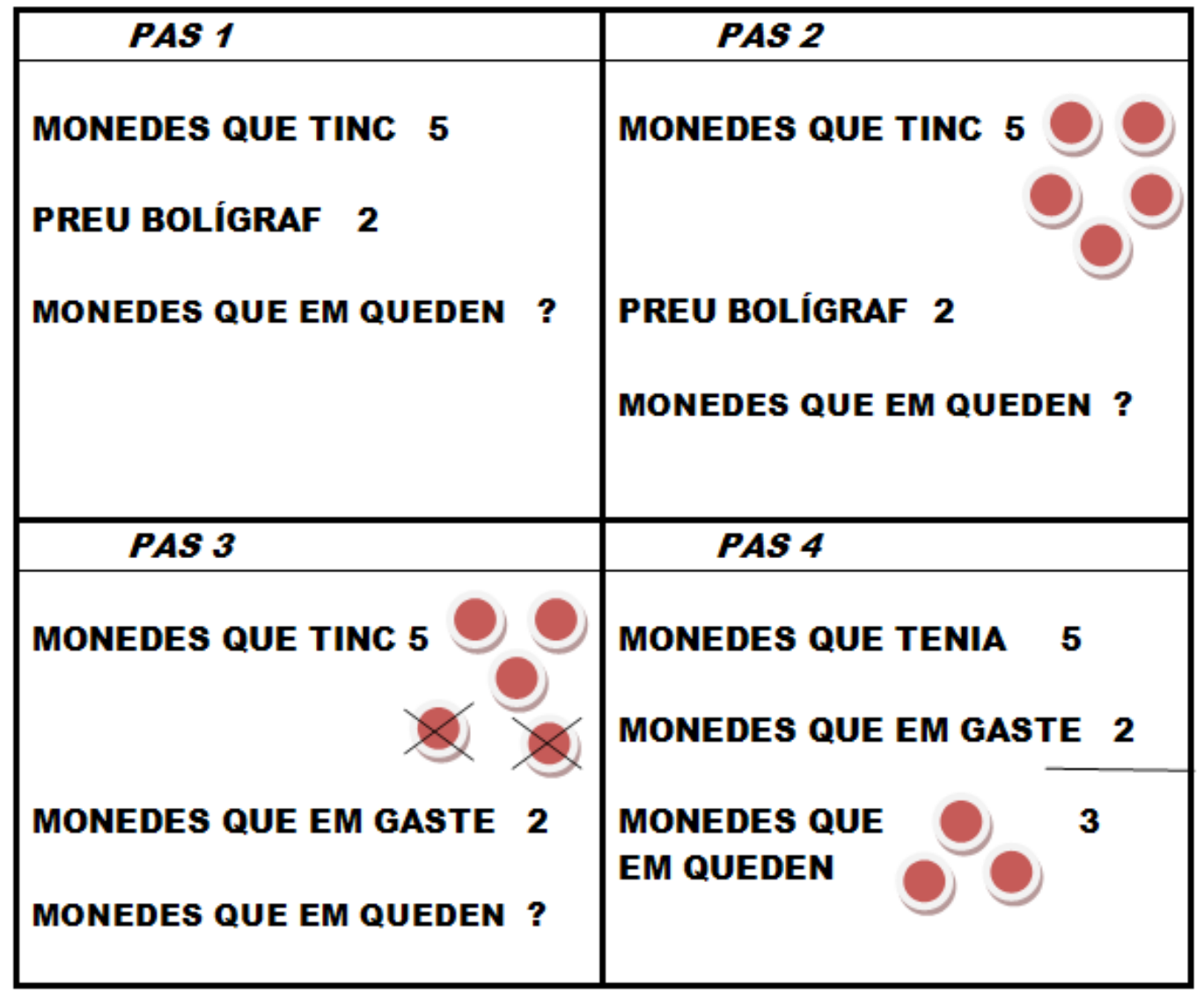

Figura 66. Representació del càlcul manipulatiu i numèric dels diners que els queden després de fer una compra

Encara que en educació infantil no és obligatòria la introducció dels signes matemàtics de les operacions, es pot iniciar la utilització del nom i del signe de l'addició en alguna d'aquestes activitats. Si el desenvolupament del curs i el nivell de l'alumnat ho permet, també es podria introduir el nom i el signe de la sostracció en activitats escrites on els xiquets i les xiquetes calculen les monedes que els quedaran després d'haver comprat uns determinats productes.

Es pot completar tot aquest treball amb activitats gràfiques realitzades a partir de catàlegs amb preus, cartells de productes, etc., i simulant el que seria una compra en la tenda corresponent utilitzant com a ajuda la llista de la compra i el tiquet.

3. Realitzar transformacions que modifiquen i que no modifiquen una quantitat (amb materials separats)

Aquesta capacitat pretén ajudar els xiquets i les xiquetes a reflexionar sobre els diferents efectes de les distintes transformacions que podem aplicar a les quantitats de materials separats.

Es treballarà només en l'últim curs del cicle, després d'haver resolt moltes situacions dels tipus que hem desenvolupat en les dues capacitats anteriors. Es tracta 
de contraposar les activitats que no modifiquen una quantitat i les que sí que la modifiquen (d'afegir o de llevar). És com la fusió dels dos apartats previs i caldrà observar el que passa i reflexionar-hi.

Front a situacions en les quals sols es canvia la distribució espacial o l'aparença dels elements (es trasllada un pilot de llibres d'una taula a una altra; es lleva l'envoltori a uns caramels; etc.) en què no es modifiquen les quantitats inicials, presentem altres en les quals hi ha accions d'afegir o de llevar elements (portem més llibres de la classe del costat; ens mengem dos caramels; etc.) i, per tant, es produeixen modificacions de les quantitats. Pretenem que l'alumnat reflexione sobre aquestes situacions i que arribe a descobrir que sols es modifica una quantitat quan afegim o llevem elements i mai en els altres casos. És a dir, que siguen capaços d'aconseguir una conservació raonada de la quantitat de materials separats i que no es deixen confondre per percepcions o apreciacions equivocades al respecte.

És probable que no tot l'alumnat de la classe arribe a entendre aquesta qüestió d'una manera definitiva. El seu tractament es reprén en 1r curs de primària amb la intenció que tots els xiquets i les xiquetes interioritzen aquest pensament i dominen els canvis de quantitats i les seues causes en tot el que es refereix a materials separats.

\section{Iniciar el càlcul mental}

Ara intentem que l'alumnat puga treballar amb els nombres sense que siga necessària la presència dels objectes que els corresponen. És un treball incipient però molt important, ja que recorre els primers passos per desenvolupar la capacitat de calcular mentalment que els xiquets i les xiquetes han d'assolir en educació primària.

Començarem amb nombres petits i amb situacions reals i properes en les quals l'alumnat té al davant el material inicial al qual es refereix l'activitat $\mathrm{i}$ han de pensar què passaria si afegiren o llevaren elements. Per exemple, hem agafat tres llapis de colors per a pintar un arbre, quants tindríem si n'agafarem dos més?, o José ha dut cinc coquetes per ser el seu natalici, quantes en quedarien si ens menjarem tres?

Més endavant provarem a llevar el material i, per tant, hauran d'imaginar què passa sense manipular cap element, treballant amb els primers nombres al principi i augmentant fins al nou més tard. Sempre s'intentarà que la situació siga el més real possible i es crearà la necessitat de modificar una quantitat a partir d'un cas concret. Per exemple, si hem de comprar una planta per a l'aula que val 3 euros i un test en el qual posar-la que val 2, quants diners necessitem?, o bé, si hem triat 7 xiquets i xiquetes per a representar un conte i 3 es posen malalts, quants en queden per fer el conte? 


\section{Iniciació a la mesura}

\section{Introducció}

En aquest tema es treballa la iniciació a la mesura, per oferir als xiquets i les xiquetes les eines matemàtiques que els ajuden a respondre les preguntes que la realitat els planteja respecte a «quant n'hi ha?» d'alguna cosa o «quan ocorren els fets?».

Comença el tema amb una referència històrica sobre els conceptes de magnitud $\mathrm{i}$ mesura i sobre el Sistema Internacional d'unitats, continua amb un breu comentari sobre la seua formalització i finalitza amb un extens tractament didàctic dels continguts corresponents a l'aula d'infantil.

\subsection{Històrica}

En física, magnitud és qualsevol propietat d'un fenomen, cos o substància, que pot expressar-se quantitativament mitjançant un nombre i una referència. ${ }^{1}$ Algunes magnituds poden ser directament apreciables pels nostres sentits, com la longitud, la massa, la superfície...; unes altres no ho són i necessiten mètodes indirectes per a mesurar-les (acceleració, energia...). S'anomenen magnituds escalars les que poden expressar-se numèricament $\mathrm{i}$ vectorials les que queden determinades per un vector. La bellesa, tanmateix, no és una magnitud, perquè no és possible elaborar una escala ni molt menys un aparell que determine quantes vegades un ésser o un objecte és més bell que no pas un altre.

La noció de magnitud està inevitablement associada amb la de mesura. Mesurar és relacionar una quantitat d'una magnitud amb una altra o unes altres de la mateixa magnitud que es consideren unitats, per saber el nombre de vegades que la unitat està continguda en la quantitat a mesurar. És a dir, l'acció de mesurar comporta tres entitats: una magnitud, una unitat d'aquesta magnitud i un nombre. La mesura és, per tant, el resultat numèric de la comparació de certa quantitat d'una magnitud amb la unitat escollida a l'efecte.

Antigament es triaven moltes unitats de referència per a mesurar un mateix tipus de magnitud. Una unitat menuda per a quantitats menudes de la magnitud i una de gran per a quantitats grans, tractant que els nombres que resultaven de comparar les quantitats de magnitud a mesurar amb la seua unitat foren nombres senzills, nombres de dues o tres xifres i tal volta una xifra decimal o dues. Així, la massa de pedres precioses es mesurava en quirats, que és una llavor de massa $0,2 \mathrm{~g}$ d'un

1. Definició de magnitud extreta del «Vocabulario Internacional de Metrología. Conceptos fundamentales y generales, y términos asociados». Ministeri d'Indústria, Energia i Turisme, 3a edició 2012, darrera visita 20-7-2016 de http://www.cem. es/sites/default/files/vim-cem-2012web.pdf. 
arbre àrab (no s'ha de confondre amb l'altra accepció de la paraula quirat, fracció màssica d'or en un aliatge multiplicada per 24, el que fa que els tipus de quirats només es puguen diferenciar pel context) i les quantitats grans d'aquesta magnitud, com per exemple les que es refereixen a les collites, en tones.

Aquesta primera manera de mesurar és clar que no és útil, perquè cada zona pot triar la seua manera particular de fer-ho. Concretament, al nostre país, la fanecada és una unitat de superfície dels camps de cultiu, que en la actualitat encara s'usa. Equival a 833,3 $\mathrm{m}^{2}$. És l'extensió de terra que es calcula que es pot sembrar amb una faneca de gra; conté quatre quartons (unitat de mesura de la terra agrícola a Mallorca) i equival a la dotzena part d'una hectàrea (unitat de mesura de superfícies al Sistema Internacional) (Dorce, 2013; 2014).

Una segona opció és adoptar una única unitat i usar-la amb els seus múltiples i submúltiples, per exemple, el metre, el quilòmetre, el mil·límetre..., i intentar que el nombre que resulta de la mesura siga un nombre còmode.

La tercera de les opcions és triar només una unitat i acceptar que el nombre que resulte de mesurar la magnitud no siga senzill. Per exemple, el diàmetre d'una agulla és $8,5 \times 10^{-5} \mathrm{~m}$, que es llegeix «vuit coma cinc, per deu elevat a menys cinc metres» $\mathrm{i}$ el diàmetre de la Terra és $1,27 \times 10^{7} \mathrm{~m}$.

Al llarg de la història aquest tema ha evolucionat notablement per diverses raons, la primera i més important, perquè la necessitat de mesurar és d'un ús quotidià habitual. No es pot fugir d'aquest fet.

\section{El Sistema Internacional d'unitats}

El primer conjunt d'unitats concebut com un sistema estable fou el Sistema Mètric Decimal, creat a França amb la Revolució Francesa a finals del segle XVIII.

En 1881, es va adoptar en el Congrés Internacional dels Electricistes, celebrat a París, el Sistema Cegesimal (CGS, inicials de centímetre, gram, segon), proposat pel matemàtic alemany Karl Gauss.

Basat en el primer, l'any 1901, el físic i enginyer italià Giovanni Giorgi proposà el sistema MKS (inicials de metre, kilogram, segon), adoptat oficialment en 1935, el qual va donar lloc, després de ser ampliat, al Sistema Internacional en 1960 (Segovia y Rico, 2011).

Actualment, arreu del món, la norma és utilitzar el Sistema Internacional (sI) d'unitats, encara que als Estats Units d'Amèrica es continua en procés de transició, des que al 1875 s'hi adoptara formalment el Sistema Mètric Decimal.

El si és el resultat del treball de diverses organitzacions internacionals durant més d'un segle, amb el qual s'ha aconseguit un sistema d'unitats de mesura comú per a totes les àrees de la ciència $i$ la tecnologia. 
Cada estat estableix adopcions i exclusions legals de caràcter formatiu o industrial. A Espanya, la Llei de pesos i mesures, de 8 de juliol de 1892; la Llei 88/1976, de 8 de novembre; el Reial decret 1317/1989, de 27 d'octubre, i la correcció d'errades; i la Norma une 82100:1996 són les que s'hi apliquen. Però, com que és estrany que es penalitze per no complir-les, es comú veure aparells destinats a mesurar la pressió graduats en $« \mathrm{~kg} / \mathrm{cm}^{2} » \mathrm{i}$, per exemple, característiques de calderes $\mathrm{i}$ refrigeradors amb mesures en «calories» $\mathrm{i}$ «frigories», respectivament.

A més d'homogeneïtzar les transaccions científiques, tècniques i comercials, un dels majors avantatges d'un sistema coherent d'unitats, com el si, és que facilita la comparació de valors dispars d'una mateixa magnitud (per exemple, distàncies microscòpiques $i$ astronòmiques) i les relacions entre les diferents magnituds.

En la nomenclatura científica els símbols usats per a les unitats no són abreviatures ortogràfiques, són només símbols. En general, aquests símbols són lletres simples o, excepcionalment, parelles o tríades.

Les normes per a la correcta utilització de magnituds, unitats i símbols científics, les proposen les associacions científiques internacionals ${ }^{2}$ (en aquest cas el Comité Internacional de Peses i Mesures) i les adopten les administracions de cada estat, amb la finalitat de facilitar els intercanvis d'informació i les transaccions materials (particularment entre organismes i empreses multinacionals).

El si està constituït per tres classes d'unitats: fonamentals, derivades i suplementàries. A una magnitud particular només li correspon un conjunt d'unitats en aquest sistema.

Les unitats fonamentals són set. Les unitats derivades provenen de la relació algebraica (multiplicació o divisió) entre les unitats fonamentals. Les unitats suplementàries són un cas particular d'unitats derivades, només n'existeixen dues, el radian i l'estereoradian, que corresponen a les magnituds angle pla i angle sòlid respectivament.

La Conferència General de Pesos i Mesures, a més, ha admès l'ús d'altres unitats que, sense pertànyer al si, són importants i àmpliament utilitzades arreu del món. Aquesta admissió és temporal i, per això, es coneixen com a unitats temporals. Alguns exemples d'aquests tipus d'unitats són els que figuren en els quadres següents:

\section{UNITATS FONAMENTALS}

\begin{tabular}{|c|c|c|}
\hline MAGNITUD & NOM & SÍMBOL \\
\hline longitud & metre & $\mathrm{m}$ \\
\hline massa & kilogram & $\mathrm{kg}$ \\
\hline temps & segon & $\mathrm{s}$ \\
\hline intensitat del corrent elèctric & ampere & $\mathrm{A}$ \\
\hline
\end{tabular}

2. La informació actualitzada respecte de les unitats, les seues relacions i les normes d'ús es pot trobar en la pàgina web del Bureau International des Poids et Mesures, http://www.bipm.org/. 


\begin{tabular}{|c|c|c|}
\hline temperatura termodinàmica & kelvin & $\mathrm{K}$ \\
\hline quantitat de substància & mol & $\mathrm{mol}$ \\
\hline intensitat lluminosa & candela & $\mathrm{cd}$ \\
\hline
\end{tabular}

\section{UNITATS DERIVADES}

\begin{tabular}{|c|c|c|}
\hline \multicolumn{3}{|c|}{ Sense nom especial } \\
\hline MAGNITUD & NOM & SÍMBOL \\
\hline superfície & metre quadrat & $\mathrm{m}^{2}$ \\
\hline volum & metre cúbic & $\mathrm{m}^{3}$ \\
\hline velocitat & metre per segon & $\mathrm{m} / \mathrm{s}$ \\
\hline acceleració & metre per segon quadrat & $\mathrm{m} / \mathrm{s}^{2}$ \\
\hline \multicolumn{2}{|c|}{ Amb nom especial } \\
\hline freqüència & hertz & $\mathrm{Hz}$ \\
\hline força & newton & $\mathrm{N}$ \\
\hline potència & watt & $\mathrm{W}$ \\
\hline resistència elèctrica & ohm & $\Omega$ \\
\hline
\end{tabular}

UNITATS ACCEPTADES QUE NO PERTANYEN AL SI

\begin{tabular}{|c|c|c|}
\hline MAGNITUD & NOM & SÍMBOL \\
\hline massa & tona & $\mathrm{t}$ \\
\hline temps & minut, hora & $\mathrm{min}, \mathrm{h}$ \\
\hline temperatura & grau Celsius & ${ }^{\circ} \mathrm{C}$ \\
\hline volum & litre & L ó 1 \\
\hline
\end{tabular}

\section{UNITATS EN ÚS TEMPORAL}

\begin{tabular}{|c|c|c|}
\hline MAGNITUD & NOM & SÍMBOL \\
\hline longitud & $\begin{array}{c}\text { àngstrom, } \\
\text { milla nàutica }\end{array}$ & $\AA$ \\
\hline energia & kilovat hora & $\mathrm{kWh}$ \\
\hline superfície & hectàrea & ha \\
\hline pressió & bar & bar \\
\hline radioactivitat & curie & $\mathrm{Ci}$ \\
\hline Velocitat & nus & \\
\hline
\end{tabular}


UNITATS DESAPROVADES PEL SI

\begin{tabular}{|c|c|c|}
\hline MAGNITUD & NOM & SÍMBOL \\
\hline pressió & atmosfera & atm \\
\hline energia & caloria & cal \\
\hline força & kilogram - força & $\mathrm{kgf}$ \\
\hline
\end{tabular}

\section{Prefixos al sI}

Per tal de no haver d'utilitzar nombres massa grans o massa menuts el si admet l'ús de múltiples i submúltiples de les unitats, que s'indiquen mitjançant uns prefixos que s'anteposen al nom de la unitat i al seu símbol. Per a anomenar un múltiple o submúltiple d'una unitat composta es recomana fer servir només un prefix; si la unitat composta és un quocient, el prefix mai ha d'acompanyar la unitat que es trobe al denominador.

\begin{tabular}{|c|c|c|}
\hline \multicolumn{3}{|c|}{ MÚLTIPLES } \\
\hline Factor & Prefix & Símbol \\
\hline $10^{18}$ & exa & $\mathrm{E}$ \\
\hline $10^{9}$ & giga & $\mathrm{G}$ \\
\hline $10^{6}$ & mega & $\mathrm{M}$ \\
\hline $10^{3}$ & kilo & $\mathrm{k}$ \\
\hline $10^{2}$ & hecto & $\mathrm{h}$ \\
\hline $10^{1}$ & deca & $\mathrm{da}$ \\
\hline
\end{tabular}

\begin{tabular}{|c|c|c|}
\hline \multicolumn{3}{|c|}{ SUBMÚTIPLES } \\
\hline Factor & Prefix & Símbol \\
\hline $10^{-1}$ & deci & $\mathrm{d}$ \\
\hline $10^{-2}$ & centi & $\mathrm{c}$ \\
\hline $10^{-3}$ & mil·li & $\mathrm{m}$ \\
\hline $10^{-6}$ & micro & $\mu$ \\
\hline $10^{-9}$ & nano & $\mathrm{n}$ \\
\hline $10^{-18}$ & atto & $\mathrm{a}$ \\
\hline
\end{tabular}

\section{Normes del SI}

Qualsevol llenguatge conté regles per escriure'l, que evita confusions i facilita la comunicació. El si té les pròpies regles d'escriptura que permet una comunicació correcta.

Pel que fa als símbols:

- Se escriuen amb caràcters romans rectes.

- S'utilitza lletra minúscula tret dels derivats de noms propis (N, Hz).

- No van seguits de punt ni prenen una $s$ per al plural $(17 \mathrm{~m})$.

- No s'ha de deixar espai entre el prefix i la unitat (nanòmetre: $\mathrm{nm}$ ).

- El producte de dos símbols s’indica mitjançant un punt. 
Pel que fa a les unitats:

- Si el valor s'expressa amb lletres, la unitat també (dèsset metres).

- Les unitats derivades de noms propis s'escriuen igual que el nom propi però amb minúscules (dos newtons).

- Els noms de les unitats prenen una $s$ en el plural, llevat dels casos d'algunes terminacions en consonants (tres metres, catorze nus, vint hertz).

\section{Formalització dels conceptes de magnitud i mesura}

L'esquema matemàtic que es necessita per tal d'abordar la definició formal de magnitud i mesura és el següent: una magnitud és un conjunt, els elements del qual s'anomenen quantitats de la magnitud i en el qual es defineixen unes operacions $i$ un ordre; una mesura és una aplicació que a cadascuna de les quantitats li assigna un nombre. Aquest nombre serà la mesura d'eixe element.

Caldrà doncs, determinar aquest conjunt, les quantitats corresponents i l'aplicació anomenada mesura.

\subsection{Concepte de magnitud}

Definirem una magnitud a partir d'un conjunt $\boldsymbol{S}$. Determinar aquest conjunt, en general, pot resultar complicat. Acompanyarem la definició amb un exemple, la longitud. $\boldsymbol{S}$ serà el conjunt de tots els objectes que tenen longitud. En aquest conjunt cal definir una relació binària d'equivalència $\boldsymbol{R}$ que relacionarà els elements del conjunt. En el cas de la longitud, aquesta RBE relacionarà els objectes que tenen la mateixa longitud. Mitjançant aquesta relació, obtenim el conjunt $\boldsymbol{S} / \boldsymbol{R}$ anomenat conjunt quocient, on els elements són ara classes d'equivalència. Cadascuna d'aquestes classes estarà formada per tots els elements que per mig d'aquesta RBE són equivalents. Per l'exemple triat, aquestes classes estaran formades per tots els objectes amb la mateixa longitud, és a dir, l'objecte en si ja no és important, ho és la seua longitud, i obtenim així la característica que interessa. Per tant, les classes d'equivalència són quantitats de longitud. Una quantitat de longitud la poden tenir molts objectes.

Perquè el conjunt quocient anterior siga una magnitud, necessitem definir en ell una operació interna, una relació d'ordre i una operació externa, que acomplisquen les següents condicions:

1. L'operació interna tindrà les propietats associativa i commutativa.

2. La relació d'ordre serà compatible amb l'operació anterior.

3. L'operació externa ens dirà quantes vegades una quantitat és més «gran» que 
una altra. Es formalitza a partir del producte d'una quantitat de magnitud per un nombre no negatiu (real o natural), és distributiva respecte de l'addició de nombres i de l'operació interna anterior i és compatible amb la relació d'ordre definida.

Amb totes aquestes condicions es diu que $S / R$ és una magnitud. Cal notar que aquesta definició correspon a les magnituds escalars.

La definició d'operació externa es refereix a magnituds escalars contínues si el conjunt numèric que utilitzem és $\mathbb{B}^{+} \cup\{0\}$ i a magnituds escalars discretes si és $\mathbb{N}$.

Aquest procediment es repeteix de manera anàloga per a construir les altres magnituds que s'estudien a l'escola.

Una formalització més extensa del concepte de magnitud es pot trobar en Pérez, Alcalde i Lorenzo (2014).

\subsection{Mesura d'una magnitud}

Mesurar serà l'acte mitjançant el qual s'assigna un nombre (natural o real no negatiu) a una quantitat de magnitud. Aquest acte (independentment de l'instrument de mesura, context i condicions ambientals) matemàticament és una aplicació que associa les classes d'equivalència del conjunt quocient anteriorment definit amb els nombres naturals o amb els nombres reals no negatius, segons el cas.

Formalment, s'anomena mesura d'una magnitud escalar continua $S / R$ a qualsevol aplicació bijectiva m: $S / R \rightarrow \mathbb{R}^{+} \cup\{0\}$ que conserva les operacions definides i que és compatible a més amb l'ordre. En el cas de les magnituds discretes $\mathbf{m}: S / R$ $\rightarrow \mathbb{N}$.

Per tant, la mesura ens permet associar les quantitats d'una magnitud escalar amb nombres que, alhora, es poden representar per punts a sobre d'una semirecta (aquests punts se situaran en el lloc dels nombres naturals, en el cas de magnituds discretes, $i$ en tots els punts de la semirecta real no negativa, en el cas de les contínues).

Les magnituds anomenades vectorials no satisfan els axiomes d'ordre que verifiquen les escalars i, en conseqüència, no es poden representar per punts d'una recta. Aquestes magnituds no es poden relacionar, per tant, amb valors reals no negatius per tal de donar la mesura. A més, cal donar informació de la direcció en la qual s'apliquen i del sentit, components que no tenen les magnituds escalars. Exemples d'aquest tipus de magnituds poden ser la velocitat, l'acceleració, la força... 


\subsection{Unitat de mesura}

Donada una magnitud escalar contínua $S / R$ i una mesura m: $S / R \rightarrow \mathbb{R}^{+} \cup\{0\}$ s'anomena unitat de mesura de $\mathbf{m}$ la quantitat $[n] \in S / R / m([n])=1$. Anàlogament, es definirà la unitat per les magnituds discretes.

\section{La iniciació a la mesura a l'aula d'infantil}

\subsection{Consideracions prèvies}

La pregunta que ens podem fer quan es tracta un tema dedicat a qüestions d'una repercussió tan important com les que s'expressen en la introducció històrica i que al llarg dels temps ha suposat tants esforços fins que s'ha aconseguit un mínim de consens internacional, és «què sap l'alumnat d'educació infantil abans d'entrar a l'aula sobre les magnituds i la seua mesura?». És cert que són conceptes que poden semblar llunyans al seu desenvolupament cognitiu, però el que sembla també cert és que estan envoltats de referents que tenen molt a veure amb la mesura de magnituds. Quan van amb els seus familiars comprar hi ha referències a diferents magnituds, per exemple, a la capacitat dels recipients de líquids que s'adquireixen, a la massa que pot tenir el producte que volen adquirir..., i al sistema monetari també. Encara més, al cotxe que segurament han pujat moltes vegades, hi ha un instrument que marca quina longitud s'ha recorregut i qui el condueix farà al·lusions a ella; o a la televisió es parla de marques de temps en esports, i per això és necessari aclarir-los que el temps és quelcom que es mesura amb rellotges que es duen a la mà, però que també estan penjats a les parets o damunt d'un moble o en els electrodomèstics i que hi ha de dos tipus, uns porten unes agulles, d'altres no...

És evident que no podem parlar d'absència de nocions de magnituds en els infants, ara bé, és ben palés també que no tenen una idea formada de manera reflexiva $i$ contrastada del que són i del que suposen. No serà al llarg d'educació infantil quan es construiran totalment aquests conceptes. Ens caldrà només iniciar el camí, esbrinar les primeres llums del que significa una magnitud i la seua mesura, per tal d'acabar de fonamentar-les bé a l'aula de primària.

En l'apartat 2 d'aquest tema es parla de la formalització dels conceptes de magnitud i mesura. És evident que no es pot realitzar un treball d'aquest nivell a les aules d'infantil o primària, però com a docents és interessant saber com, des d'un concepte tan genèric com la relació binària d'equivalència $i$ la formació a partir d'ella del conjunt quocient, els elements del qual són les classes d'equivalència, s'arriba a la construcció d'una maquinària matemàtica que dóna resposta a tot el que suposa analitzar i construir de manera general els conceptes del tema. 
Resulta curiós advertir com la pràctica més elemental de la iniciació a la idea de mesura a les aules d'infantil o primària manté paral·lelismes amb aquestes construccions més formals o teòriques. Si agafem l'exemple de la necessitat d'una unitat patró, això es manifesta quan es vol comunicar el que s'ha fet a classe (per exemple, quan comparem les capacitats de dos recipients grans amb gots diferents) als seus pares i mares a casa o a uns altres companys/es de les aules del costat, perquè la necessitat d'entendre'ns ens porta a la de disposar d'una unitat comuna coneguda i utilitzada per tothom. I aquest fet es posa de manifest espontàniament. Tot això, és clar, manipulant, comparant, estimant...

Per tant, la mesura serà la ferramenta matemàtica que ens permet quantificar la realitat formada per materials continus. Com que la unitat triada per a mesurar pot variar per a la mateixa magnitud, el resultat de la mesura dependrà d'aquesta, és a dir, serà relatiu a la unitat utilitzada. Aquest fet fa més complicada per a l'alumnat escolar la tasca de mesurar que la de comptar. A més, de vegades també és necessari utilitzar instruments especials i complicats per als xiquets i les xiquetes, cosa que encara dificulta més aquest treball.

Per avançar en el desenvolupament de totes les nocions relacionades amb la mesura, caldrà anar creant en l'alumnat la idea de magnitud com tot allò susceptible de poder ser mesurat i també que, per tal de fer-ho, necessitem les unitats de mesura, els nombres, la idea de divisió d'un tot en parts agregades, el transport de la unitat sobre la quantitat a mesurar i la seua repetició totes les vegades que siga necessari.

\subsection{Capacitats per desenvolupar a l'aula d'infantil}

Com establir els primers passos d'una manera seqüencial i adequada en l'educació infantil respecte de la mesura serà l'objectiu del tema, contribuint a desenvolupar en l'alumnat les següents capacitats:

1. Comparar objectes diferents per les seues dimensions per a establir contrastos: gran-petit, llarg-curt, alt-baix, ample-estret, gros-prim.

2. Comparar objectes diferents pel seu pes per a establir nocions: pesat-lleuger.

3. Comprovar amb la balança anticipacions intuïtives realitzades sobre el pes de diferents objectes.

4. Relacionar quantitats de materials continus sòlids per la semblança (tan com) o per la diferència (més_que, menys _ que).

5. Construir (manipulativament i gràficament) objectes de diferents dimensions.

6. Transvasar materials continus líquids o àrids entre recipients de diferent grandària, comparant les seues capacitats.

7. Relacionar per la semblança o per la diferència diversos recipients amb diferents quantitats de materials continus líquids o àrids.

8. Establir relacions d'equivalència i d'ordre en funció de la longitud, la capacitat i la massa.

9. Iniciar experiències de mesura de longituds, capacitats i masses. 
10. Realitzar transformacions que modifiquen i que no modifiquen una quantitat (amb materials continus).

11. Captar, per mitjà de situacions quotidianes, les nocions bàsiques relacionades amb el temps.

12. Situar en el temps diferents fets quotidians.

13. Representar seqüències temporals per mitjà de dibuixos successius.

14. Ordenar seqüències temporals representades gràficament.

15. Comparar la durada del temps en dues accions diferents.

16. Identificar una hora, un dia, una setmana.

\subsection{Desenvolupament de les capacitats}

Amb les mateixes consideracions de l'apartat 3.3 del tema 1, estudiarem a continuació els procediments per a construir els primers conceptes referents a magnituds i mesura a l'aula d'educació infantil.

\section{Comparar objectes diferents per les seues dimensions per a establir contrastos: gran-petit, llarg-curt, alt-baix, ample-estret, gros-prim}

Aquesta capacitat està treballada en el tema 1, concretament en la capacitat 1 , però l'hem inclosa també ací perquè el coneixement d'aquestes característiques dels objectes i les comparacions entre elles constitueixen els primers passos per arribar més endavant a la necessitat de quantificar exactament les diferències i a través d'ella a la utilitat de la mesura.

\section{Comparar objectes diferents pel seu pes per a establir nocions: pesat-lleuger}

En aquesta capacitat es treballarà una de les característiques dels objectes que no havíem treballat encara: la massa.

Cal considerar la massa com la magnitud que mesura la quantitat de matèria que té un cos. Aquesta resulta invariant quan canvien les condicions d'altura, pressió, situació geogràfica... El pes és la força que la gravetat exerceix sobre un cos i depén de la seua massa, a més d'altres factors. Aquest sí que és variable en funció de les característiques esmentades anteriorment. La massa és la magnitud per estudiar, però com que generalment situarem la nostra activitat docent en un mateix entorn geogràfic, la treballarem mitjançant la seua manifestació, el pes, que romandrà invariable en no canviar les condicions anteriors.

Començarem en aquest treball amb l'alumnat comparant dos objectes reals amb pesos molt diferents, però adequats a les seues possibilitats físiques. Per exemple, si els xiquets i les xiquetes estan ajudant a organitzar el material escolar en les prestatgeries corresponents, poden comparar el pes d'un paquet de 500 fulls i d'un de guix. Caldrà que els manipulen, que els toquen i en funció de la sensació 
que tinguen, que expliquen quin els sembla més pesat. En la verbalització de les activitats utilitzarem un vocabulari que els ajude a transmetre aquestes experiències: «pesa poc», «pesa molt», «pesa més», "pesa menys». El docent pot anar utilitzant també les paraules «pesat» $\mathrm{i}$ «lleuger » sense que l'alumnat tinga que dominar-les.

Més endavant, es realitzarà un treball semblant, amb dos objectes els pesos dels quals no siguen ara tan diferents (per exemple, dos caixes de retoladors, una de 12 i una altra de 24 unitats) arribant de manera progressiva a comparar objectes que pesen igual (una caixa de guixos blancs i una altra de guixos de colors). En el reforç del vocabulari associat ampliarem les expressions esmentades abans afegint-hi ara «pesen igual».

Per a realitzar les estimacions sobre el pes dels objectes caldrà que l'alumnat adopte unes posicions corporals semblants a les de la balança (braços oberts cap els costats del cos o cap endavant i perpendiculars al tronc en els dos casos) per tal de percebre millor i amb més claredat la diferència de pesos (figura 67).

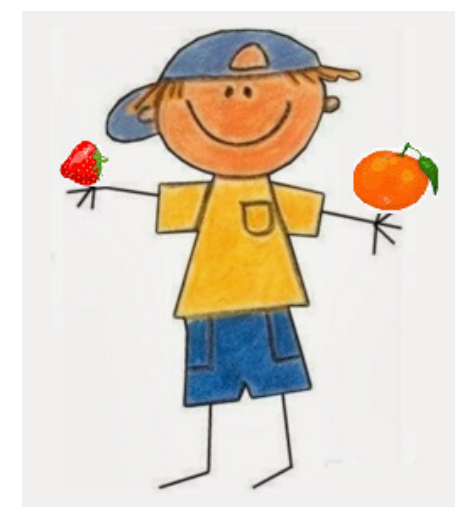

Figura 67. Representació d'un xiquet en posició de balança sospesant unes fruites

Cap al final del cicle compararan aleatòriament objectes que pesen igual o diferent, augmentant la quantitat d'objectes i la variabilitat de pesos. Treballarem sempre amb objectes quotidians $i$ haurem d'aconseguir que els xiquets i les xiquetes finalitzen l'etapa expressant correctament les comparacions entre els pesos dels objectes i la seua condició de pesats o lleugers.

3. Comprovar amb la balança anticipacions intuïtives realitzades sobre el pes de diferents objectes

Aquesta capacitat completa el treball de la anterior, de manera que els dubtes que es presenten quan la diferència de pes siga petita o els objectes que es comparen tinguen el mateix pes, han de resoldre's amb una balança de plats (figura 68). 


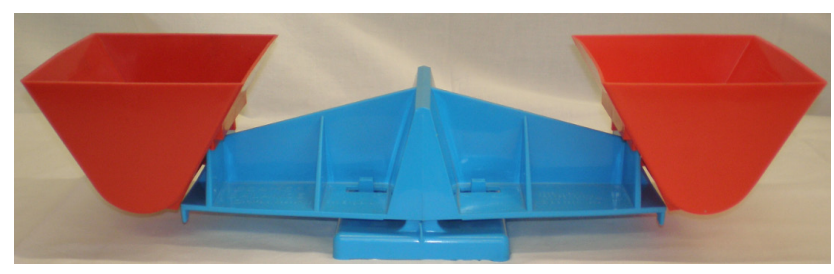

Figura 68. Representació d'una balança (fabricada per Osmiroid)

Introduirem aquest instrument cap a la segona meitat del cicle, per tal de comprovar les estimacions intuïtives sobre el pes que s'havien fet amb anterioritat. Però, és clar, usar un instrument implica saber com funciona. Així, una vegada es presenta com l'eina que ens ajudarà a resoldre els nostres dubtes sobre diferències de pesos, cal fer un parèntesi i manipular aquest nou aparell.

La manipulació començarà amb objectes de pesos molt diferents i, tot i que no presenten dubtes a l'hora d'estimar amb les mans quin pesa més o menys, els posarem en la balança per tal d'observar el comportament dels plats, comprovant que baixa el que conté l'objecte més pesant i descobrint així com funciona (de manera anàloga al que ocorre amb els seus braços). Després, quan ja siga un instrument conegut i manipulat, de manera progressiva, s'usaran pesos més semblants o també iguals (els plats queden a la mateixa altura) fins a arribar a conèixer les posicions dels plats en tots els casos.

Més endavant (en la capacitat 9) les activitats s'encaminaran a utilitzar la balança, ja no només per comparar pesos, sinó també per a mesurar el pes d'un objecte utilitzant com a unitats elements de l'entorn. Després, quan es troben a primària, seran peses convencionals les que s'utilitzaran per tal d'equilibrar els plats de la balança.

\section{Relacionar quantitats de materials continus sòlids per la semblança (tan_com) o per la diferència (més_que, menys_que)}

Al llarg del 2n cicle d'infantil i acompanyant la resta de capacitats de totes les magnituds que es treballen, usarem el vocabulari que s'explicita en el títol de la capacitat perquè l'alumnat expresse correctament les comparacions d'objectes que realitze respecte de les característiques que conega en cada moment: més llarg que, més baix que, tan gruixut com, etc. Per tal que puguen arribar a fer-ho, en un primer moment el docent les expressarà en contextos que no es presten a confusió. Per exemple, en situacions de joc en què l'alumnat construïsca trens o torres amb blocs encaixats, verbalitzaran si uns són més o menys llargs o alts respectivament que no altres; o també si els troncs d'uns arbres del pati són més o menys gruixuts que no altres. Posteriorment $\mathrm{i}$ de manera natural, caldrà que ells $\mathrm{i}$ elles usen aquests termes.

A més de reconèixer les semblances o diferències entre dos objectes que tenen al davant, han de treballar també la cerca d'entre diversos objectes d'un que com- 
plisca unes determinades condicions respecte d'un altre que els oferirem com a model: de la carpeta dels papers xarol, porta'n un més ample que aquest; de la caixa de les cordes, dus-ne una menys llarga que aquesta; de la cistella dels pals de fusta, porta'n un que siga tan alt com aquest; etc.

Es pot completar aquest treball manipulatiu amb activitats gràfiques en les quals compararan objectes representats gràficament o hauran de buscar algú en una imatge amb unes condicions donades respecte d'un altre, verbalitzant correctament les comparacions (figura 69).

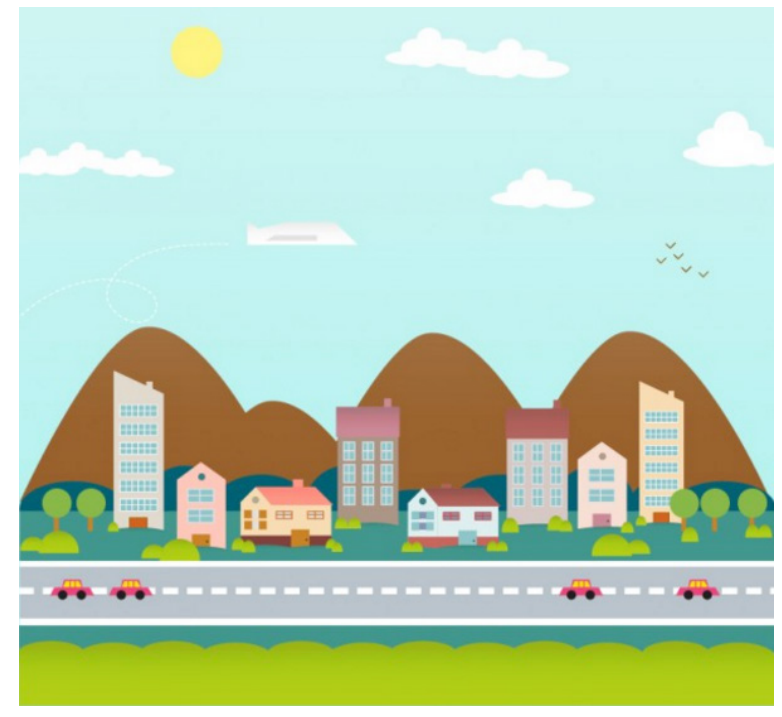

Figura 69. Representació d'alguns edificis d'una ciutat

\section{Construir (manipulativament i gràficament) objectes de diferents dimensions}

Durant els dos darrers cursos del cicle i associat amb situacions que es presenten a l'aula, el que es pretén és que hi construïsquen objectes de diferents dimensions. Al principi no és una activitat lliure, cal tenir un model al davant, proporcionat pel docent, per poder observar-lo, fer el que es demana i comprovar després que s'han seguit les indicacions de més, menys o igual referides a les diferents dimensions dels objectes. Per exemple, hem tallat una corda per a lligar un paquet i ens resulta curta, els demanem que en tallen una altra que siga més llarga o que retallen un paper igual d'ample que un altre per a embolicar una caixa, etcètera.

Més endavant ja no serà el docent qui els mostre el model, seran ells i elles qui construiran diferents objectes amb les condicions de semblança o diferència que se'ls haja proposat. Per exemple, per a fer els troncs de dos arbres d'un mural han de preparar dos cilindres de plastilina, un més gruix que l'altre o per a fer el teulat d'una casa que forma part d'una maqueta han de tallar dos trossos de cartolina, igual de grans.

També es pot treballar gràficament i que siga dibuixant la manera de crear els diferents objectes. Per exemple, per tal de fer un mural d'una ciutat, els oferim imatges 
d'alguns edificis i ells i elles han de dibuixar uns altres amb característiques diferents (d'altura, d'amplària, etc.) als proporcionats.

Tant en el treball manipulatiu com en el gràfic hem de propiciar que l'alumnat expresse correctament les comparacions entre objectes que hi apareguen.

\section{Transvasar materials continus líquids o àrids entre recipients de diferent grandària, comparant les seues capacitats}

Comencem en aquesta capacitat el treball amb materials continus que necessiten un recipient per a poder manipular-los: els líquids o els àrids (grans, llegums i altres materials sòlids que, per qüestions pràctiques, es quantifiquen mitjançant la mesura).

En un primer moment es comparen per la seua capacitat recipients de grandàries molt distintes i formes semblants, comprovant si hi cap o no el material d'un en transvasar-lo a l'altre. Per exemple, podem comparar la capacitat d'un poal d'escurar en què hem posat terra per a treballar en l'hort escolar i la d'un poal de platja que utilitzarem per transportar-la. Per a expressar les observacions s'usarà un vocabulari adequat, com hi cap/no hi cap, ple/buit.

Quan estiguen clares les diferències dels casos inicials, compararan recipients de grandàries menys diferents $\mathrm{i}$ de formes menys semblants com ara un got $\mathrm{i}$ una copa, per exemple, amb l'increment del vocabulari afegint a les expressions anteriors la idea de mig ple, quan la situació ho requerisca.

Hem d'aconseguir que, en finalitzar l'etapa d'educació infantil, l'alumnat siga capaç de comparar la capacitat de recipients de formes prou diferents i grandàries més semblants (envàs de iogurt, de crema catalana, bric de suc, etc.) expressant correctament el que observen.

\section{Relacionar per la semblança o per la diferència diversos recipients amb diferents quantitats de materials continus líquids o àrids}

En aquest moment cal introduir l'ús del vocabulari de les comparacions que hem vist a la capacitat 4: més que, menys que, tan _ com, igual _ que, per al cas del materials líquids o àrids.

Iniciarem el treball en el $2 \mathrm{n}$ curs del cicle amb les activitats més senzilles, comparant recipients de la mateixa grandària i formes molt semblants amb diferents quantitats de materials (arribaran a distintes altures) per a diferenciar molt-poc i expressar les relacions hi ha més_que o hi ha menys_que. A continuació i amb recipients com els anteriors, compararan les mateixes quantitats de materials (arribaran a la mateixa altura) per a observar la igualtat i expressar hi ha igual_que o hi ha tant _com. Per exemple, podem utilitzar gots o botelles de plàstic amb di- 
ferents o iguals quantitats d'aigua per a regar les plantes de classe o l'hort escolar, si n'hi ha.

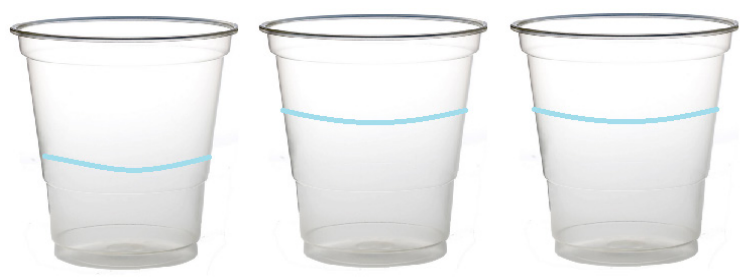

Figura 70. Representació de gots amb diferents quantitats d'aigua (tots dos de l'esquerra) i amb la mateixa quantitat (tots dos de la dreta)

Més endavant s'utilitzaran recipients de grandàries i formes distintes amb diferents quantitats de líquids o àrids per a observar les diferències i amb les mateixes quantitats de materials perquè descobrisquen la igualtat. Aquesta darrera es podria considerar la comparació més complicada i les raons són obvies. En aquest cas es pot fer necessari utilitzar algun instrument (got, pot, etc.) com a unitat de mesura per a comprovar amb ella el que intueixen en aquestes comparacions o per desmentir allò que asseguren equivocadament.

Al llarg de totes aquestes activitats l'alumnat ha d'anar utilitzant el vocabulari associat a elles de manera correcta i natural.

\section{Establir relacions d'equivalència i d'ordre en funció de la longitud, la capacitat i la massa}

A les capacitats 13 i 15 del tema 1 ja es treballaren relacions d'equivalència i d'ordre amb la longitud i la grandària dels objectes. Seguint els mateixos passos que en aquell tema s'establien, caldrà incorporar ara les característiques dels objectes que s'associen a la seua massa i les dels recipients que es deriven de la seua capacitat, per a utilitzar-les com a criteris de classificacions o d'ordenacions de la mateixa manera que s'ha fet en les dues magnituds anteriors.

Aquest treball es realitzarà al llarg de tot el cicle, tenint en compte que amb la massa l'avanç és més lent que amb les altres magnituds i que, a diferència d'aquestes, per a les quals no necessitem cap instrument que faça d'intermediari, ens haurem d'ajudar de la balança per fer les comparacions que ens permeten establir les relacions entre les masses treballades.

\section{Iniciar experiències de mesura de longituds, capacitats $i$ masses}

A partir d'aquesta capacitat ja no és suficient la comparació d'objectes respecte d'aquestes propietats físiques, ara es busca una quantificació concreta i precisa de les diferents magnituds mitjançant la seua mesura. 
Cap a la segona meitat del cicle intentarem trobar situacions reals idònies per tal de crear la necessitat que ens duga a mesurar qualsevol de les tres magnituds. Aquestes situacions poden estar immerses dins d'unes altres o de projectes de treball o d'accions més globals que puguen tenir un altre objecte d'interés. En la mesura que es contextualitze el treball d'aquesta manera, les experiències cobraran un sentit afegit, la qual cosa no s'aconseguiria si es desenvoluparen aïlladament.

Respecte de la longitud, per exemple, si necessitem traure la taula de la mestra al passadís per fer una exposició de treballs de l'alumnat, podem preguntar-los com esbrinar si cabrà la taula per la porta, tenint en compte que pesa molt i és un gran esforç arrossegar-la per a comprovar-ho directament. En una situació d'aquest tipus és convenient que no hi haja a l'aula cap objecte que siga més llarg que la taula i la porta (per exemple un tros de corda, un pal, un regle...) que ens permeta respondre la pregunta amb una simple comparació. El nostre interés és aconseguir que proposen algun objecte com a unitat de mesura que siga necessari repetir diverses vegades per recobrir les longituds que cal mesurar.

Com encara no estem pensant en introduir les unitats convencionals, es poden utilitzar dos tipus d'unitats:

- Unitats naturals: aquelles que deriven del propi cos, com per exemple peus, pams, colzes...

- Unitats arbitràries: aquelles que poden prendre del seu voltant, com ara 1lapis, bolígrafs, palets, cordes o qualsevol objecte semblant.

El procediment consisteix a col·locar, una al costat de l'altra, totes les unitats de mesura que siguen necessàries per recobrir totalment les longituds per mesurar. En l'exemple anterior, i suposant que han triat els peus dels xiquets i les xiquetes com a unitat de mesura, el que farien és situar els peus de diversos alumnes recobrint les dues longituds que es vol mesurar i, després de comptabilitzar els peus de cadascuna, fer la comparació corresponent per poder resoldre el seu dubte. En aquest treball hem d'insistir en la necessitat d'expressar el resultat obtingut utilitzant el nombre i la unitat triada per a mesurar. Així, no diran que la taula mesura 4 i la porta 7 , sinó que la taula medis «4 peus» i la porta «7 peus» i, per tant, sí que es pot traure la taula al passadís (figura 71).
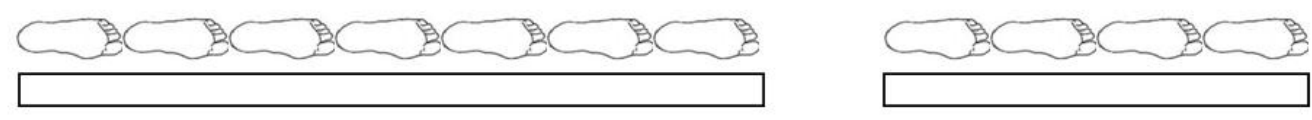

Figura 71. Representació del càlcul experimental de la mesura de les longituds d'una taula i una porta amb diversos peus iguals

És clar que estem usant unitats de mesura no homogènies (els peus dels xiquets i les xiquetes no són exactament igual de llargs) però podem obviar aquestes diferències amb la finalitat d'insistir en la idea d'unitat de mesura per damunt d'altres qüestions. 
Si en esbrinar les mesures de les longituds s'obtingueren nombres molt elevats per als coneixements de l'alumnat, es podria repetir la mesura amb una unitat més llarga per a obtenir nombres més petits o bé es faria la comparació mitjançant una correspondència biunívoca associant un a un els peus de les dues longituds fins que s'acabaren els d'una d'elles i decidint aleshores quina és la més llarga.

Si es produeix una situació en la qual la quantitat d'unitats que s'utilitzen no recobreix exactament la longitud que cal mesurar, es podria també repetir la mesura amb una altra unitat per intentar millorar l'exactitud o expressar la mesura amb «7 peus i un tros» o bé menysprear el tros que quede sense recobrir-lo si aquest és poc important en el resultat final.

Quan aquestes primeres experiències de mesura estiguen treballades i utilitzant el mateix tipus de unitats, se'ls pot plantejar una pregunta sobre la possibilitat de mesurar longituds amb un sol objecte com a unitat (un únic peu, un únic llapis...). La resposta ens ha de dur a esbrinar la mesura transportant aquesta unitat al llarg de la longitud que cal mesurar tantes vegades com siga necessari per recórrer-la completa (figura 72). En aquest cas i per saber el resultat de la mesura, aniran assenyalant amb una ratlla cada vegada que transporten la unitat, visualitzant d'aquesta manera i una vegada finalitzat el mesurament, quantes vegades la longitud total conté la unitat triada.

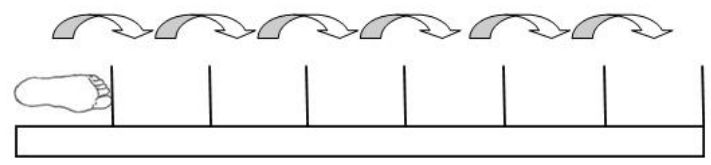

Figura 72. Representació del càlcul experimental de la mesura de la longitud d'una taula mitjançant el transport d'una sola unitat fent marques

Més endavant ja no serà necessari marcar les ratlles que ens assenyalen les vegades que es repeteix la unitat, sinó que es farà un recompte simultani amb l'acció de transportar-la, obtenint al final el nombre que ens dóna el resultat de la mesura (figura 73). Insistirem en la necessitat d'expressar aquest resultat donant el nombre i la unitat utilitzada com hem comentat abans.

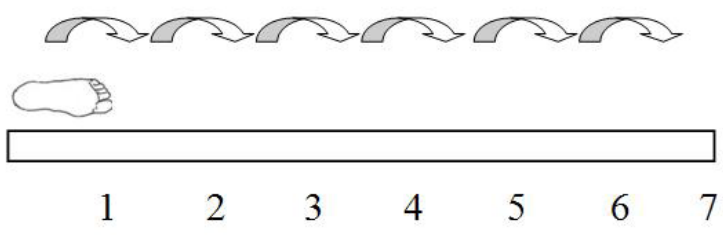

Figura 73. Representació del càlcul experimental de la mesura de la longitud d'una taula comptabilitzant el transport d'una sola unitat de longitud

Cap al final de l'etapa caldrà iniciar alguna activitat que els faça veure la dependència de la mesura respecte de la unitat triada. Si seguim amb l'exemple de la taula i la porta, podem fer grups en classe i que cadascun d'ells mesure les longituds 
amb unitats diferents (uns en peus, altres en pams, altres en barretes de guix, etc.), observant després la disparitat de resultats (la taula mesura 4 peus, 3 pams, 6 barretes de guix) i reflexionant sobre aquest fet per a aconseguir-hi una explicació raonada. Posteriorment, en primària, es reprendrà aquest tipus d'activitats per tal de justificar la introducció de les unitats convencionals.

Respecte de la capacitat, seguirem un procediment totalment anàleg al desenvolupat per a la longitud. Així, s'iniciaran experiències de mesura de la capacitat a partir també de necessitats creades en situacions reals i utilitzant ara com a unitats gots, pots o caixes del nostre context habitual per a mesurar els materials líquids o àrids amb els quals treballem.

Podem començar, per exemple, amb la comparació de les quantitats de suc que hi ha en dos gerros diferents que hem preparat per a un berenar en classe. Utilitzarem com a unitat tants gots iguals com siga necessari per buidar el contingut de cadascun dels gerros i després farem la comparació tenint en compte totes les consideracions que hem fet abans per al cas de la longitud (figura 74).
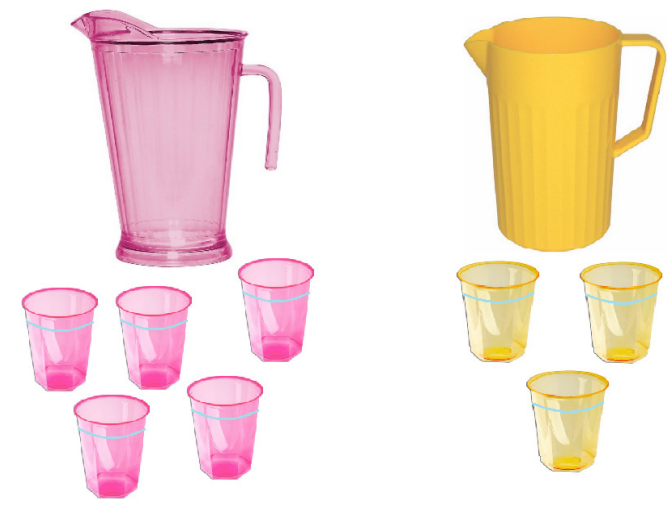

Figura 74. Representació del càlcul experimental de la mesura de la capacitat de dos gerros amb diversos gots iguals

Més endavant s'utilitzarà un objecte només per tal de realitzar aquests mesuraments. De la mateixa manera que es feia en la longitud, anirem posant-hi marques per cada vegada que s'òmpliga la unitat quan es realitze la mesura i les comptarem després per fer la comparació. Finalment, caldrà anar fent el recompte simultani sense necessitat d'anotar res.

Al llarg de tot aquest treball insistirem també en la necessitat d'expressar el resultat de qualsevol mesura utilitzant el nombre i la unitat triada per a mesurar. A més a més, realitzarem activitats que posen de manifest que, de la mateixa manera que passava en la longitud, el resultat obtingut quan s'amida depén de la unitat de mesura triada.

Respecte de la massa, serà convenient esperar fins a l'últim curs de l'etapa per a treballar-la. Com hem explicat en la capacitat 3, ens ajudarem de la balança per comparar les masses de diferents objectes i per aclarir més tard quan pesa exactament un més que un altre. 
Així, es faran activitats encaminades a equilibrar els plats de la balança posant un objecte en un d'ells i diversos objectes iguals, que seran les unitats de mesura, en l'altre. Per exemple, la recepta d'un pastís de poma i nous que farem a l'aula ens indica que hem de posar el mateix pes d'ambdós ingredients. Per tant, necessitem saber quantes nous ens fan falta per a igualar el pes d'una poma. Per tal d'esbrinar-ho usarem la balança, equilibrant els seus plats, posant la poma en un d'ells i les nous necessàries en l'altre. Caldrà expressar sempre els resultats amb el nombre i la unitat (la poma pesa 7 nous, per exemple) i realitzar comprovacions que posen de manifest la dependència del resultat de la mesura respecte de la unitat utilitzada. Així, poden pesar també la poma amb figues seques, cireres, quadradets de xocolata i reflexionar sobre els diferents resultats que s'hi obtenen.

\section{Realitzar transformacions que modifiquen i que no modifiquen una quantitat (amb materials continus)}

De manera anàloga a la capacitat 3 del tema anterior, aquesta també pretén ajudar els xiquets i les xiquetes a reflexionar sobre els diferents efectes de les distintes transformacions que podem aplicar a les quantitats de materials, en aquest cas continus.

Es treballarà només en l'últim curs del cicle, comparant i contrastant situacions en les quals no es modifique la quantitat amb d'altres on sí que es modifique (d'afegir o de llevar).

Front a situacions en què sols es canvia la distribució espacial o l'aparença dels elements (s'enrotlla una corda que estava estirada; es canvia l'aigua d'una ampolla a un gerro; es converteix en rosquilleta una pilota de plastilina; etc.), en què no es modifiquen les quantitats inicials, presentarem d'altres en les quals hi haja accions d'afegir o de llevar material (tallem un tros d'una corda; afegim a l'aigua d'un poal un poc d'aigua de l'aixeta; llevem un pessic de la plastilina d'una bola per a fer un ninot, etc.) i, per tant, es produeixen modificacions de les quantitats. Pretenem que l'alumnat reflexione sobre aquestes situacions i que arribe a descobrir que sols es modifica una quantitat quan afegim o llevem material i mai en els altres casos. És a dir, pretenem que l'alumnat siga capaç d'assolir una conservació raonada de la quantitat de materials continus, que no es deixe confondre per percepcions o apreciacions equivocades al respecte.

Aquesta pretensió resulta prou més difícil d'aconseguir que en el cas dels materials separats, ja que segurament la majoria de l'alumnat d'infantil no arribarà a entendre la qüestió per als continus. El seu tractament es reprèn en els primers cursos de primària amb la intenció que els xiquets i les xiquetes interioritzen aquest pensament $i$ dominen els canvis de quantitats $i$ les seues causes en tot el que es refereix a materials continus. 


\section{Captar, per mitjà de situacions quotidianes, les nocions bàsiques relacionades amb el temps}

Quan es parla del temps, cal tenir en compte que aquesta magnitud té un caràcter especial i que el seu desenvolupament és molt diferent al de les altres magnituds. És per això que el seu treball d'iniciació a nivell experimental i pràctic no té res a veure amb el realitzat amb les magnituds anteriors i l'adquisició competencial d'aquesta segueix un procés més lent que no les altres.

Ens posarem com a objectiu ajudar-los a observar el pas del temps, a descobrir que molts dels fets que ocorren tots els dies segueixen una mateixa seqüència $i$ a situar-se i situar accions en el temps, mitjançant el que podem anomenar coordenades temporals. Aleshores caldrà anar creant en l'alumnat una xarxa de referents temporals que el seu conscient puga assimilar i que els permeta aconseguir tot allò esmentat abans.

Desenvoluparem aquest treball des de l'inici del 2n cicle d'educació infantil, començant pel tractament de les diferències entre el dia i la nit. En un primer moment es buscaran referències estables (la claror o l'obscuritat del color del cel, la presència o l'absència de llum natural...) que sempre es donen i que no depenen de si el dia està assolellat o ennuvolat o de les fases de la Lluna. Com a complement d'aquests referents, ressaltarem la presència del Sol en el cel durant la majoria dels dies i de la Lluna en algunes nits. La referència a les estrelles, que en principi sempre estan relacionades amb la nit, es veu obstaculitzada per la contaminació lumínica en les ciutats i la impossibilitat de veure-les amb facilitat. Caldrà relacionar el dia i la nit amb els fets quotidians que realitza l'alumnat (anar al col·legi, dinar, jugar, dormir...), per a ajudar-los a què els situen de manera rutinària en algun dels referents temporals estudiats.

Per a ampliar aquestes qüestions inicials i relacionat amb el pas del temps i, per tant, amb el present, el passat i el futur, es treballaran els conceptes abans, ara i després. Ens aproximarem a aquestes referències temporals a partir del present, amb la utilització de la paraula ara per a referir-nos a l'instant en el qual ocorre el que estem fent en eixe mateix moment, per exemple, si preguntem a un xiquet què està fent $i$ ens respon, «menjar el meu entrepà», insistirem en verbalitzar «ara estàs menjant l'entrepà». Per introduir les altres expressions haurem d'enllaçar el que estem fent amb el que acabem de fer (passat) o amb el que farem quan finalitzem (futur) i, així, incloure en el nostre vocabulari i dotar de sentit les expressions abans i després per indicar aquests moments i perquè l'alumnat vaja incorporant-les al seu. En el mateix exemple anterior, si preguntem a algun xiquet què acaba de fer i ens respon, rentar-me les mans, nosaltres direm «abans de menjar ens rentem les mans» i si li preguntem què farà quan acabe de menjar i ens respon "guardar el saquet en la motxilla», nosaltres direm «després de menjar guardem el saquet en la motxilla».

Relacionat amb aquests referents temporals i prenent com a referència el temps del dinar i els conceptes de dia i nit, s'amplia el treball anterior amb la introducció 
de al matí com la part del dia que transcorre abans de dinar, a la vesprada com la part del dia que es situa després de dinar i abans que el cel es torne fosc i a la nit com la part del dia que ja tenen identificada i associada amb l'obscuritat del cel. Els tipus de situacions i les preguntes que els podem formular són del mateix estil que les expressades anteriorment.

En el darrer curs del cicle es treballen els conceptes ahir, avui i demà, centrant novament l'atenció en el moment present, avui, i identificant ahir com el dia abans d'avui i demà com el dia de després d'avui. Per a treballar aquestes nocions ens ajudarem de les rutines diàries que es fan a l'aula amb el calendari per posar la data, dels natalicis de l'alumnat, de les excursions previstes, etc. (figura 75), que ens permetran observar amb ells els dies que passen, els que falten per a anar al circ, els que fa que anàrem a la granja-escola, etc., i que donaran sentit a les expressions associades «ahir, avui i demà».

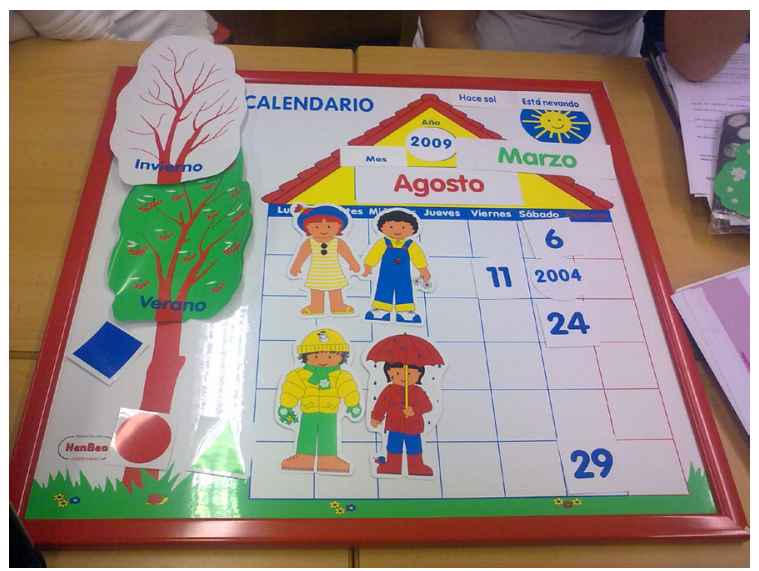

Figura 75. Calendari magnètic (fabricat per HenBea)

Aquest referents temporals costen més de distingir i assimilar que els anteriors, especialment la idea de demà, que els crea molts problemes perquè els sembla que no existeix, ja que quan pregunten si «ja és demà», resulta que és «una altra vegada avui». Probablement, la major part de l'alumnat terminarà l'etapa d'infantil sense haver comprés completament aquestes darreres nocions temporals, però normalment les dificultats es resolen en $1 \mathrm{r}$ de primària.

Cal establir també les diferències entre els dies feiners, els de col·legi, i els dies de cap de setmana, que són no lectius per als xiquets i les xiquetes, igual que els dies festius especials que apareixen de vegades entre els dies feiners.

Prestarem atenció també a les estacions de l'any, sobretot als canvis que es produeixen en passar d'una a l'altra, observant les diferents temperatures, els menjars que també són diferents, la roba que portem en cadascuna d'elles i les activitats que es desenvolupen tant en l'escola com en casa i que no seran tampoc iguals en les diferents estacions. Utilitzarem els noms de les estacions de manera habitual, per tal que l'alumnat els integre en el seu vocabulari de forma natural. 
Al llarg de tot aquest treball haurem d'informar els pares i les mares del que estem fent a l'aula i demanar la seua ajuda per tal de reforçar en casa les nocions temporals que es desenvolupen en l'escola i de treballar les que no s'hi presenten.

\section{Situar en el temps diferents fets quotidians}

Aquesta capacitat està totalment lligada a l'anterior i es refereix a la necessitat de contextualitzar tot el treball que hi desenvolupem mitjançant activitats quotidianes.

Serà essencial, per tant, estudiar les nocions temporals bàsiques relacionant-les amb les distintes activitats que l'alumnat realitza de forma habitual en els diferents moments del dia. Aquesta relació es treballarà al llarg de tot el cicle i resulta molt important que es verbalitze correctament utilitzant les expressions corresponents associades a tots els referents temporals estudiats. Així, per exemple, anem a l'escola quan és de dia, dormim en casa quan és de nit, desdejunem de bon matí, berenem a la vesprada, avui és el meu natalici, ahir estava malalt de les angines, demà és festa, som a l'hivern perquè fa molt de fred, a l'estiu anem a la platja...

A més d'aquest treball que es refereix puntualment a situar en el temps alguns fets aïllats, és molt important potenciar també la narració per part dels xiquets i les xiquetes de diferents activitats o situacions que han viscut al llarg del dia per observar si utilitzen adequadament les expressions relacionades amb el pas del temps i si el relat és clar i segueix un ordre temporal lògic.

\section{Representar seqüències temporals per mitjà de dibuixos successius}

Com hem comentat en la capacitat anterior, a més de conèixer els referents temporals treballats fins ara, l'alumnat d'infantil ha de ser capaç d'ordenar en el temps de manera lògica una successió de fets que han tingut una determinada continuïtat.

Així, completarem el treball verbal esmentat abans atenent el de representació gràfica que puguen fer els xiquets i les xiquetes i que es plantejarà com una manera de recordar el que ha passat o de poder guardar-lo per si ens fa falta més endavant o de poder mostrar-ho a altres persones. Començarem partint d'un fet que acaba d'ocórrer a l'aula (la narració d'un conte o d'una història personal, la realització d'un joc, la interpretació d'una cançó...) i demanant-los que representen gràficament, amb seqüències ordenades, allò que els ha semblat més interessant i que es referisca a moments importants del que ha succeït.

Es treballa normalment en els dos darrers anys de l'etapa i es comença demanant que representen dos o tres escenes o moments per a intentar arribar cap al final del cicle fins a quatre o cinc escenes. És important que l'alumnat explique després de fer els dibuixos què és el que ha representat i per què ho ha fet així, cosa que els ajudarà a millorar i perfeccionar les seues capacitats d'expressió verbal i gràfica. 


\section{Ordenar seqüències temporals representades gràficament}

En aquesta capacitat no es treballa a partir d'un fet ocorregut a l'aula, sinó d'una història que mostrem als xiquets i les xiquetes representada en diferents imatges desordenades i que han d'entendre i ordenar. És necessari escoltar la interpretació que fan del que veuen a les imatges per poder ajudar-los si ho necessiten abans que intenten ordenar-les.

Prestarem una atenció especial a les seqüències que poden ordenar-se tant de manera ascendent com descendent (vestir-se/desvestir-se, per exemple) acceptant qualsevol de les dues si el xiquet o la xiqueta ho explica correctament, així com a les que es refereixen a fets que són cíclics (el cicle de l'aigua o els cucs de seda, per exemple) i que poden ordenar-se començant i acabant per diferents imatges.

Es treballa també en els dos darrers cursos d'infantil i, de la mateixa manera que en la capacitat anterior, es comença per seqüències amb dos o tres escenes, amb la intenció d'arribar-hi fins a cinc o sis. Podem ajudar-nos de materials didàctics comercialitzats com el que es mostra en la figura 76.

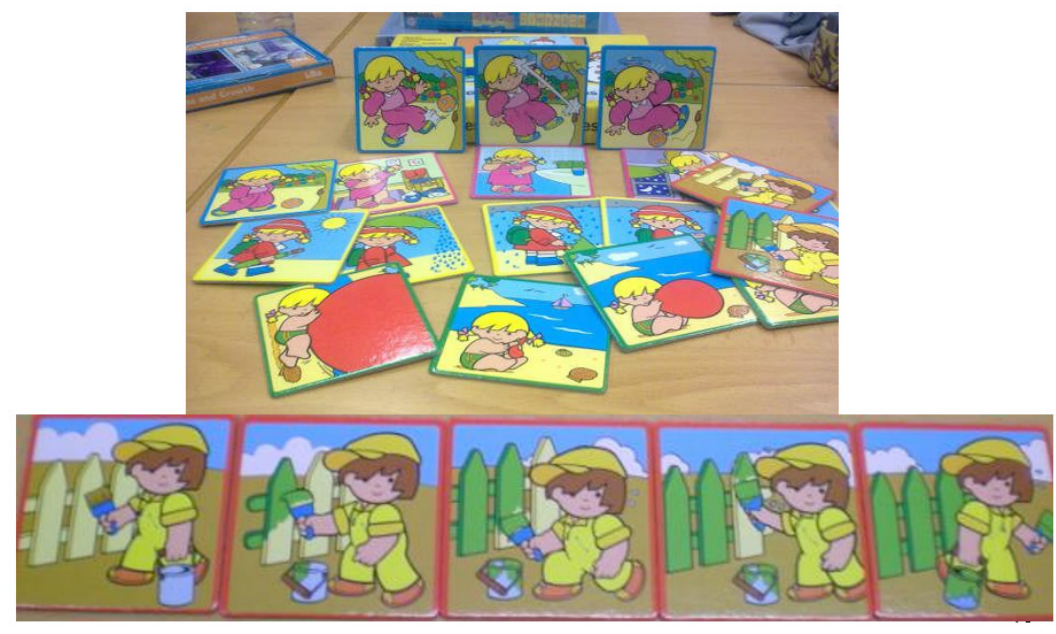

Figura 76. Seqüències temporals Zaro i Nita (fabricat per Akros)

\section{Comparar la durada del temps en dues accions diferents}

Com hem comentat en la capacitat 11, el desenvolupament de la magnitud temps en l'alumnat no és igual que el de les altres magnituds. En aquest sentit, 1'aproximació a la mesura del temps que es fa en aquesta etapa no segueix els mateixos passos que hem vist per a la longitud, la capacitat i la massa.

Inicialment anem a comparar les durades de dues accions diferents, com a pas previ per arribar més tard a la mesura del temps.

En un primer moment, l'alumnat compararà la durada del temps en dues accions simultànies que comencen alhora $\mathrm{i}$ acaben amb una gran diferència temporal 
(un xiquet comença a pintar un arbre al mateix temps que un altre comença a menjar-se un entrepà, per exemple) observant que dura menys temps l'acció que finalitza abans de les dues i més temps la que ho fa després. Acompanyant les accions i mentre parla amb l'alumnat del que està ocorrent, el docent verbalitzarà adequadament ha durat o ha tardat molt/poc de temps, més/menys temps, ..., amb la intenció que els xiquets i les xiquetes utilitzen també aquestes expressions cada vegada amb més encert i correcció (Raül ha tardat més temps a menjar-se l'entrepà que Jordi a pintar l'arbre, per exemple).

Més endavant caldrà comparar també la durada del temps en dues accions simultànies amb unes diferències temporals no tan grans com les d'abans, però amb la intenció progressiva d'arribar-hi a la igualtat. Completarem el vocabulari anterior afegint ha durat o ha tardat el mateix temps, ha durat o tardat igual, intentant que l'alumnat faça servir ja aquestes expressions sense cap problema.

Caldrà també comparar la durada del temps en dos accions no simultànies, sabent que sempre estarà present el problema de la subjectivitat en la percepció del pas del temps i que no podrem convèncer l'alumnat que hem estat més temps al pati que fent alguna tasca a l'aula, per exemple, mentre no disposem d'algun instrument alié a nosaltres, que ens permeta objectivar el pas del temps i poder afirmar sense errors de percepció si una acció ha durat més o menys que una altra.

Precisament amb la introducció d'aquest instrument, i en el darrer curs de l'etapa, quan els xiquets i les xiquetes ja es relacionen millor amb el temps, serà el moment d'objectivar la seua durada, cosa que no vol dir encara usar instruments per a mesurar-lo, sinó sols per comparar les durades i poder estar segurs de quin període dura més que un altre o si duren igual.

Amb aquesta finalitat utilitzarem per exemple els rellotges d'espelmes, de sorra o d'aigua. El funcionament d'aquests tres instruments és molt semblant i el procediment per a introduir-1 os a l'aula també ho és. L'explicarem pel cas de les espelmes.

Necessitarem dues espelmes exactament iguals i les disposarem en una base sobre la qual queden en posició vertical (xapa de fusta amb dos forats per ficar-les, per exemple). Posarem una cartolina darrere d'elles i unida a la base, per poder fer marques que indiquen les altures de les espelmes.

En primer lloc, i per a validar el funcionament del dispositiu en les comparacions objectives de durades de temps que fem, observarem en classe com es comporten les espelmes quan comparem dues accions simultànies. Marcarem en la cartolina una ratlla indicant l'altura de les dues espelmes (que serà la mateixa) i les encendrem quan comencen les dues accions. Apagarem cadascuna d'elles quan finalitze l'acció que li corresponga i tornarem a marcar unes altres ratlles indicant ara les noves altures de les dues espelmes. L'alumnat sap quina acció ha durat més i quina ha durat menys temps perquè han començat a la vegada $i$, quan observen les marques de la cartolina, comprovaran que l'espelma que s'ha cremat molt correspon 
a l'acció que ha durat més temps i la que s'ha cremat poc està associada a l'acció que ha durat menys temps (es compara l'espelma que s'ha cremat i no la que queda per evitar relacions inverses que puguen complicar la interpretació dels xiquets i les xiquetes).

Una vegada comprovat i validat el funcionament d'aquest instrument, podem utilitzar-lo per comparar la duració d'accions no simultànies sense cap problema amb la subjectivitat en la percepció del pas del temps. En aquests casos, associarem una espelma a cada acció i encendrem i apagarem cadascuna d'elles quan comence i acabe l'acció corresponent, assenyalant les altures respectives amb ratlles com en el cas anterior. Després sols caldrà comparar el tros que s'ha cremat per saber quina acció ha durat més (figura 77), amb la seguretat que hem eliminat el problema de la percepció personal del pas del temps.

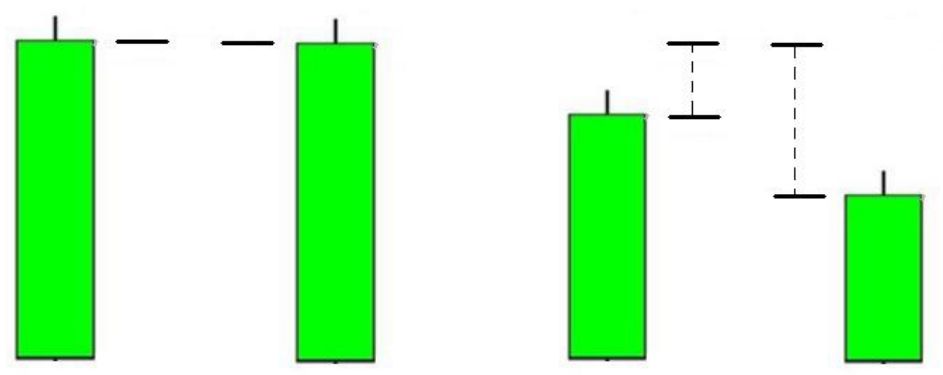

Figura 77. Representació del càlcul experimental del pas del temps amb espelmes: situació inicial (esquerra) i final (dreta)

La possibilitat de comparació de la durada del temps en accions distintes, millora la relació de l'alumnat amb aquesta magnitud però encara no els permet mesurar-lo. En aquest moment sols saben quin període ha durat més o menys, però no quant de temps més o menys ha durat un respecte de l'altre.

Per poder respondre aquesta última pregunta haurem de mesurar el temps i per a això necessitarem els rellotges i les unitats convencionals de mesura del temps, que s'iniciaran de manera incipient en la capacitat següent i que es desenvoluparan de manera completa en educació primària.

\section{Identificar una hora, un dia, una setmana}

En aquesta capacitat realitzarem una aproximació a les unitats més quotidianes de mesura del temps i que dins del llenguatge comú apareixen amb molta freqüència. En realitat, l'alumnat no les veu com unitats sinó com nous referents temporals que afegiran als ja coneguts de les capacitats anteriors i que els ajuden en el treball de situar-se en el temps i situar els diferents fets en què participen i les accions que hi realitzen.

Per la seua dificultat reservarem aquest treball per a l'últim curs de l'etapa i començarem parlant de l'hora. Per tal d'introduir-la, es poden usar rellotges escolars 
amb el format dels rellotges analògics i que disposaran, per tant, d'una maneta (o busca) curta (horària) i una altra més llarga (minutera). Associarem l'hora a la duració d'alguns períodes de temps dins de l'aula i tindrem com a referència per a observar la seua durada, un rellotge que estiga en funcionament i un dels escolars que no funcionen. Al principi del temps que vulguem considerar observaran l'hora en el rellotge que funciona i posaran la mateixa hora en l'altre (és convenient treballar amb hores en punt). Quan el docent sàpiga que ha passat l'hora els ho farà notar verbalitzant-ho (ja ha passat una hora des que estem en classe, ja ha passat una hora des que hem tornat del pati...) i revisaran l'hora que marca el rellotge en funcionament, comparant les posicions de les seues busques amb les de l'altre rellotge. En aquests moments han d'observar que la maneta curta ha passat d'un nombre al següent $i$ els farem conscients que la llarga ha fet una volta completa, amb l'ajuda d'un rellotge auxiliar en el qual podem desplaçar les busques de manera sincronitzada (figura 78).

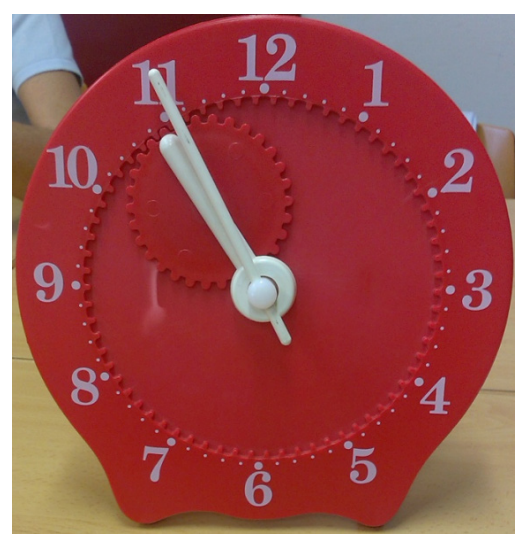

Figura 78. Rellotge d'engranatges (fabricat per Kalmarsund)

Aleshores associarem l'hora amb el temps que tarda la maneta llarga en fer una volta completa al rellotge o la curta en passar d'un nombre al següent i podem treballar amb ells la lectura d'algunes hores. És convenient informar els pares i les mares del que estem fent en classe respecte de les hores, perquè puguen ajudar-nos des de casa completant el coneixement d'algunes hores en què mai són a l'escola, insistint que només cal reforçar el treball que es fa a classe, sense introduir minuts i segons, ni rellotges digitals.

Respecte del dia, aquest és considerarà de manera conjunta com el període de temps integrat pel matí, la vesprada i la nit, conceptes que ja s'han estudiat en capacitats anteriors. Com que treballar el principi i el final del dia pot resultar un poc complicat per a l'alumnat (a les dotze de la nit, habitualment estan dormint), per tal de fer significatiu el pas d'un dia a un altre, optarem per la identificació d'un dia amb el període de temps que transcorre des que ens alcem del llit fins que ens tornem a alçar, que és una forma més fàcil de tractar aquesta qüestió amb els xiquets i les xiquetes. Es treballa conjuntament amb els conceptes d'ahir, avui, demà i tornaran a ser de gran ajuda les rutines diàries amb el calendari per situar-se en un o altre dia i per saber quan ha acabat un dia i comença el següent. 
Quant a la setmana, com que és un període de set dies, es relaciona amb l'estudi fet els dies de col·legi i els del cap de setmana. Podem ajudar-nos també de les rutines esmentades abans i de l'elaboració conjunta amb l'alumnat de calendaris setmanals, en els quals s'apleguen els set dies, que es consideraran complets quan els dilluns comentem amb l'alumnat què han fet durant el cap de setmana i siga conscient del pas d'aquest parell de dies que no han estat a l'escola. Utilitzarem calendaris com el que es mostra a la figura 79, en el què podem composar cada setmana, a més d'oferir-los altres informacions sobre els referents temporals socials. No cal que s'aprenguen ordenadament els noms dels dies de la setmana, sols que sàpiguen quins són i que diferencien els feiners del que no ho són.

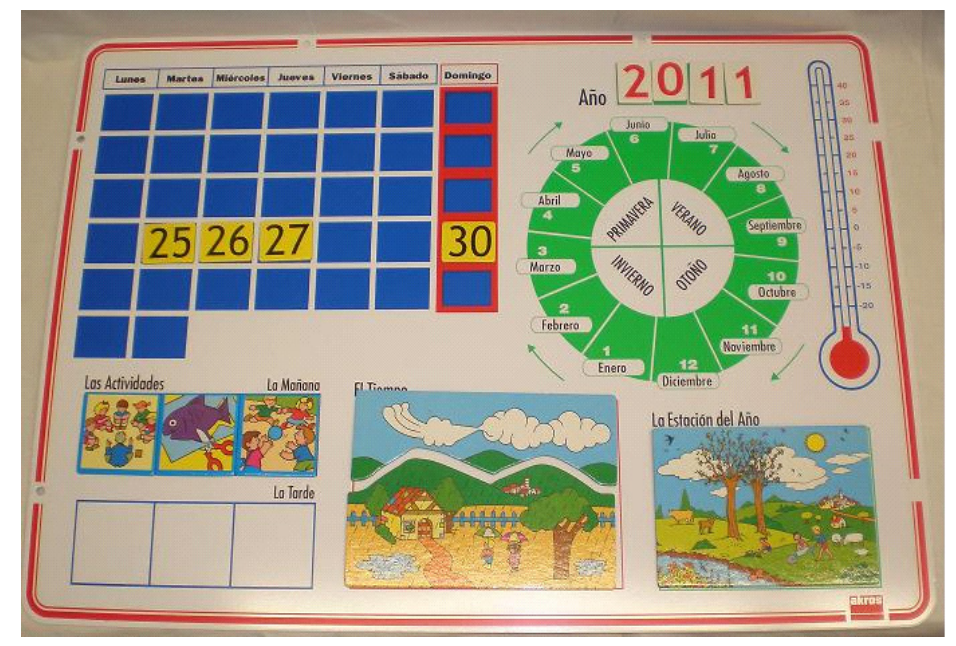

Figura 79. Calendari escolar (fabricat per Akros) 


\section{TEMA 5}

\section{Primeres nocions espacials i geomètriques}

\section{Introducció}

En aquest tema es treballen les primeres aproximacions al seu context espacial, per oferir als xiquets $i$ les xiquetes les eines matemàtiques que els ajuden a respondre les preguntes que la realitat els planteja respecte a «com són els objectes?, on estàs tu i on es troben aquests?, com es relacionen espacialment?».

Comença amb una referència històrica sobre la geometria, seguida d'una reflexió sobre les diferents geometries que existeixen i d'un recull teòric sobre els conceptes corresponents que necessitarà el docent d'infantil. Finalitza amb un extens tractament didàctic dels continguts geomètrics per al seu desenvolupament en aquesta etapa educativa.

\subsection{Històrica}

Del grec gea, terra, i metron, mesura, la geometria, des dels seus orígens, va ser l'encarregada de resoldre problemes de la realitat. Un tipus de problemes se centrava en la mesura i reconstrucció de terrenys i camps de cultiu (Segovia i Rico, 2011). Un altre es referia a la necessitat de fer construccions arquitectònicament estables, cosa que es podia aconseguir dotant-les d'una certa estructura geomètrica. La cerca de solució a aquests problemes proporcionava a la humanitat eines matemàtiques per controlar l'entorn i servir-se'n. Els grecs combinaren aquesta utilitat de la geometria purament pràctica, amb altres aspectes de caire teòric (Argüelles, 1989) i artístic (frisos, mosaics, sanefes, etc.).

Tot i que filòsofs com Aristòtil (segle IV aC) sostenen que la geometria va nàixer a Egipte, gràfics i dibuixos del Neolític ja mostren interés per les distribucions espacials. Concretament en aquest país trobem el Papir Rhind, que es va publicar l'any $1700 \mathrm{aC}$. Conté una col·lecció de 84 problemes de caràcter aplicat, com ara càlcul d'àrees de terra, capacitat de magatzems, etc. En el problema 50 s'indica com calcular l'àrea d'un cercle amb una aproximació molt precisa de $\pi$; en el 51 , l'àrea d'un triangle i, en el 52, l'àrea d'un trapezi isòsceles. En el problema 56 es demana calcular el volum d'una piràmide regular de base quadrangular, coneguts el costat de la base i l'altura. En aquestes i altres troballes egípcies s'observen patrons comuns per a resoldre alguns tipus de problemes, tot i que encara no hi ha evidència de cap document que sistematitze $\mathrm{i}$ justifique els processos emprats. 
La civilització mesopotàmica, i en concret els babilonis (molt avançats en matemàtiques), disposaven de molts coneixements geomètrics que els permetien resoldre problemes pràctics, com per exemple càlculs d'àrees de diferents superfícies. De la mateixa manera que en el cas dels egipcis, tampoc no es coneix cap escrit que generalitze els diferents procediments de resolució d'aquests problemes.

Els matemàtics grecs van recollir el llegat dels egipcis i dels mesopotàmics i progressaren fins a elaborar un cos de coneixements que sistematitzava els anteriors, justificant i demostrant els diferents processos i generalitzant els conceptes geomètrics necessaris per a desenvolupar-los. Foren els seus màxims exponents Tales de Milet (segle vi aC) i Pitàgores (segles VI-V aC), amb els seus coneguts resultats pel que fa a l'estudi dels triangles.

Plató (segles v-IV aC), deixeble de Sòcrates (segle v aC) i mestre de Aristòtil (segle IV $\mathrm{aC}$ ), va optar per la utilització de la matemàtica pura en la geometria. Va ser el fundador del que es coneix com Escola Platònica, a la qual li devem:

- La classificació dels políedres regulars (políedres convexos determinats per polígons regulars iguals els vèrtexs dels quals són uniformes, és a dir, en ells s'uneix la mateixa quantitat de cares o arestes). El mot políedre prové del grec polýhedros; de polýs, molt, i hédra, cara. Atesa la importància que l'Escola Platònica els hi va donar, avui en dia es coneixen com a sòlids platònics. Aquests són: el tetràedre, el cub o hexàedre, l'octàedre, el dodecàedre i l'icosàedre, tots aquests regulars. Plató associa a aquests sòlids els elements foc, terra, aire, el material amb el qual es van formar les constel·lacions i el cel (univers), i l'aigua, respectivament.

- La determinació de successives aproximacions a l'àrea del cercle mitjançant el mètode exhaustiu o per esgotament que, posteriorment, consolidarà Arquímedes.

Euclides va recopilar la matemàtica que es coneixia fins a aquell moment en els tretze llibres que componen els Elements, al voltant de l'any $300 \mathrm{aC}$ (Dorce, 2013). És, possiblement, l'obra matemàtica més llegida (per ser la més editada) al 1larg de la història. En els volums dedicats a la geometria va descriure, entre altres continguts, com construir figures amb regle i compàs, $i$ va enunciar que només hi ha cinc políedres regulars.

A finals del segle XVI, Kepler imaginà una relació entre els cinc políedres regulars i les òrbites dels planetes del sistema solar aleshores coneguts (Mercuri, Venus, Mart, Júpiter i Saturn). Segons ell, cada planeta es movia en una esfera separada de la contigua per un sòlid platònic.

D'altra banda, els sòlids arquimedians, també coneguts com semiregulars (políedres convexos formats per polígons regulars de dos o més tipus amb vèrtexs uniformes) deuen el nom a Arquímedes, que els va descobrir i estudiar al segle III $\mathrm{aC}$. Tot i que el seu treball es va perdre, en tenim constància per un altre de Pappus 
d'Alexandria. Serà Kepler als segles XVI i XVII qui va demostrar que només poden haver-hi tretze políedres amb aquestes característiques (Dorce, 2013).

La geometria exposada és només una part de l'anomenada descriptiva, que s'ha desenvolupat al llarg dels segles mencionats. A partir del segle XVI comença a introduir-se la situació de les figures en el pla i l'espai mitjançant coordenades. Aquest fet és molt important, perquè origina una geometria més analítica i comença a abandonar-se la representació gràfica com a únic suport dels càlculs. Tot aquest coneixement de la matemàtica més geomètrica s'articula a partir de cinc axiomes exposats per Euclides, que cal considerar com a veritats absolutes. Mai no s'havien qüestionat, però tampoc demostrat. Un en concret, el cinquè, o axioma del paral·lelisme, diu que «per un punt exterior a una recta, es pot traçar només una paral·lela a ella». Fins al segle XIX no es va posar en dubte aquest postulat i seran Gauss (1777-1855), Bolyai (1775-1856) i Lobachewski (1792-1856), els qui, de manera separada, no sols no l'asseveren sinó que encaminen els respectius estudis suposant la seua falsedat, i creen, així, la geometria hiperbòlica.

Amb els treballs de Riemann (1826-1866) sobre la geometria esfèrica i la teoria de la relativitat d'Einstein (1879-1955) incloent-hi el temps en la concepció geomètrica de l'univers, es produeix l'explosió de les geometries no euclidianes.

L'existència d'aquestes geometries va provocar l'interrogant al voltant de què és, realment, la geometria. El 1872, el matemàtic alemany Felix Klein (1849-1925) va respondre a aquest interrogant amb la publicació del seu Programa d'Erlangen, on classifica les diferents geometries a partir de grups de transformacions geomètriques (Stewart, 2008; Dorce, 2014).

Actualment, aquesta part de la matemàtica investiga nous coneixements en els camps de la topologia i la geometria algebraica.

\subsection{Al tema}

Si posem la mirada en l'educació infantil, la geometria adquireix la capacitat de ser la part de la matemàtica encarregada de vehicular la relació espacial dels xiquets i les xiquetes amb el món que els envolta. Assumint que aquest món és tridimensional, caldrà descobrir les infinites direccions que hi ha per moure-s'hi i veure'n quines són possibles en funció del context on es trobe l'individu que ha d'iniciar el moviment i dels interessos que dictaminen modificar-lo.

Com que aquesta part inicial de la geometria, la de l'exploració de l'espai, va molt lligada al desenvolupament natural de les persones en aquestes edats, ens podem trobar que, a grans trets, la intuïció els farà adquirir aquestes capacitats de manera autònoma. Però un treball de situació, reconeixement i reproducció de posicions d'objectes en l'espai i l'ordre que ocupen en funció d'uns altres, els ajudarà, indubtablement, a l'adquisició de nocions geomètriques bàsiques (línies, superfícies i espai) que els dotaran dels estris adequats per a treballar de manera més simbòlica en primària aquests conceptes. 
L'objectiu del tema és, d'una banda, donar a conèixer els conceptes, elements rellevants, propietats i característiques de les figures geomètriques que es treballen a l'escola i, de l'altra, com s'ha de fer la transposició didàctica d'aquesta part de la geometria a l'aula d'educació infantil.

\section{Els primers passos per la geometria}

\subsection{Preliminars}

L'evolució dels primers conceptes geomètrics, basada en el procés d'abstracció que la Humanitat fa de les formes de l'entorn i de la seua idealització, ha produït la immensitat de ramificacions geomètriques que hi ha en l'actualitat. Són moltes les persones que han investigat $\mathrm{i}$ investiguen en la branca de les matemàtiques dedicada a la geometria, i que fan gran inversió d'hores en línies de treball de tal potencial d'abstracció, que ni tan sols podríem imaginar.

Però, l'essència més primitiva, intuïtiva o descriptiva d'aquesta primera geometria, la que s'encarrega del coneixement de l'espai (considerat com el conjunt de tots els punts existents) i de les figures geomètriques, és la que ens interessa per a les aules d'infantil i primària. I la raó és ben senzilla, cal dotar l'alumnat d'eines perquè sàpiga orientar-se en el seu entorn (que, a més, està en contínua transformació) i perquè siga capaç de descriure i classificar allò que l'envolta.

Si s'assumeix, com a punt de partida, la definició de figura geomètrica, com qualsevol conjunt de punts en l'espai, sembla lògic pensar que l'evolució natural dels conceptes matemàtics hauria de ser estudiar els punts, després les línies, més tard les superfícies i, per a finalitzar, els cossos geomètrics.

Aquesta concepció s'enfronta amb la percepció que hi ha en els xiquets i les xiquetes d'educació infantil i de primària de la seua realitat i l'aproximació que poden fer-hi. Si s'atén a qüestions de psicomotricitat, de desenvolupament cognitiu i de coneixement general del medi on viuen, l'aproximació didàctica hauria d'adreçar-se primer als cossos geomètrics (poden agafar-los, manipular-los...), després a les figures geomètriques planes que els limiten, com els llindars d'aquestes figures i cossos, més endavant a les línies (costats o arestes) i, per a finalitzar, com a interseccions d'aquestes línies, als punts. En l'àmbit de la matemàtica formal, cal fer el recorregut contrari per poder definir un objecte geomètric de més envergadura a partir de l'anterior.

En tot el treball que es desenvolupe a l'aula caldrà tenir en compte la impossibilitat de materialitzar les figures geomètriques de menys de tres dimensions. Les rectes o triangles que es poden dibuixar o observar en un objecte, només són representacions perceptibles dels conceptes matemàtics abstractes. Perquè una recta, com a concepte, és un ens infinit i il·limitat que no té grossor i, per tant, no es pot cons- 
truir físicament. Per la segona raó (la inexistència de grossària) s'arriba també a la impossibilitat de poder construir materialment un triangle, un cercle i, en general, qualsevol figura plana.

\subsection{Geometries}

Els canvis que afecten l'entorn de l'alumnat vénen donats per les modificacions de les figures geomètriques que s'hi troben. El que fa que unes figures geomètriques es transformen en unes altres són les transformacions geomètriques. En la realitat, una transformació és una deformació, una projecció, un desplaçament, etc. Matemàticament, aquestes transformacions les podem abstraure en aplicacions bijectives de l'espai en si mateix que agafen una figura geomètrica i la transformen en una altra. Però, quines propietats de la figura original es conserven en la figura transformada o homòloga? Dit d'una altra manera, quines seran les característiques invariables de la figura geomètrica original, per aquestes transformacions?

D'acord amb el Programa d'Erlangen, publicat per Felix Klein en 1872, l'estudi d'aquestes propietats invariables el fa la geometria i, com que hi ha diversos tipus de transformacions, podem mencionar diferents geometries.

Si estudiem més detingudament les transformacions que hi poden aparèixer, tenim:

1. Transformacions topològiques. Si es pot parlar d'una escala d'intensitat en les transformacions a les quals poden estar sotmeses les figures geomètriques, les que ocupen un dels llocs més alts en aquella escala serien les transformacions topològiques, que deformen, estiren o contrauen, i provoquen grans canvis en la figura original però sense produir-li trencaments, per la qual cosa s'anomenen també bicontínues. Exemples d'aquestes transformacions serien les que es poden apreciar en la figura 80 .
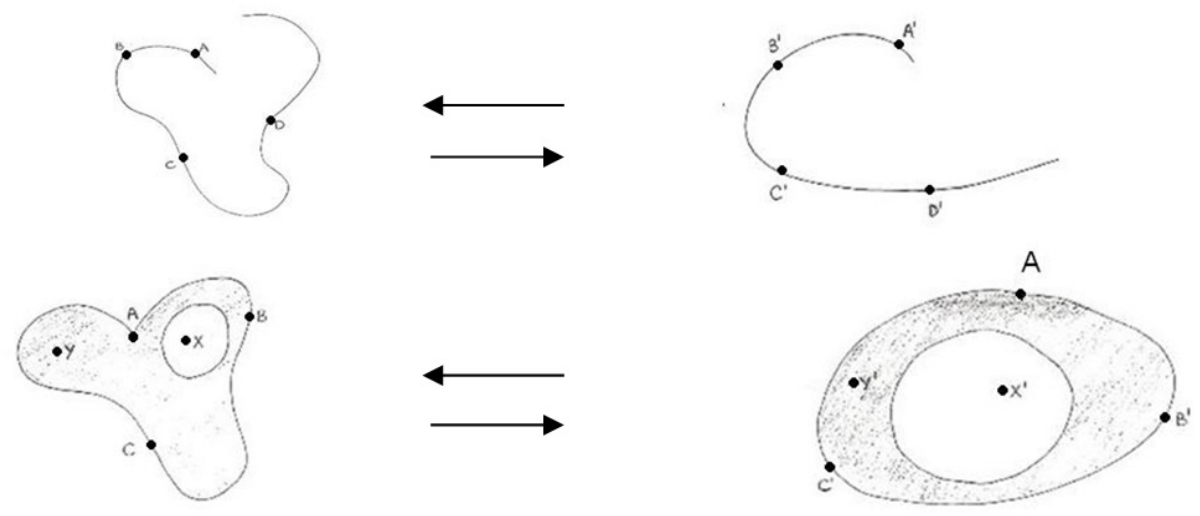

Figura 80. Exemples de transformacions topològiques

Com s'hi pot observar, aquestes transformacions no conserven longituds, ni angles, ni mesures de cap tipus, però sí que hi ha unes altres propietats que 
es conserven. Per exemple el caràcter d'obert o tancat d'una figura; el seu interior i exterior; l'ordre dels seus punts.

2. Projeccions. Si ara es compara una figura plana amb l'ombra que hi fa sobre un pla (per obtenir sols una aproximació intuïtiva a aquestes transformacions), observarem que, segons on estiga el focus de llum (prop o en l'infinit) i com estiga el pla (paral·lel o no al que ocupa la figura) on es projecta aquesta ombra, hi trobarem diferents tipus de transformacions, anomenades projeccions o transformacions projectives.

Totes elles conserven les línies rectes i corbes i també la convexitat, com es pot veure en la figura 81 .
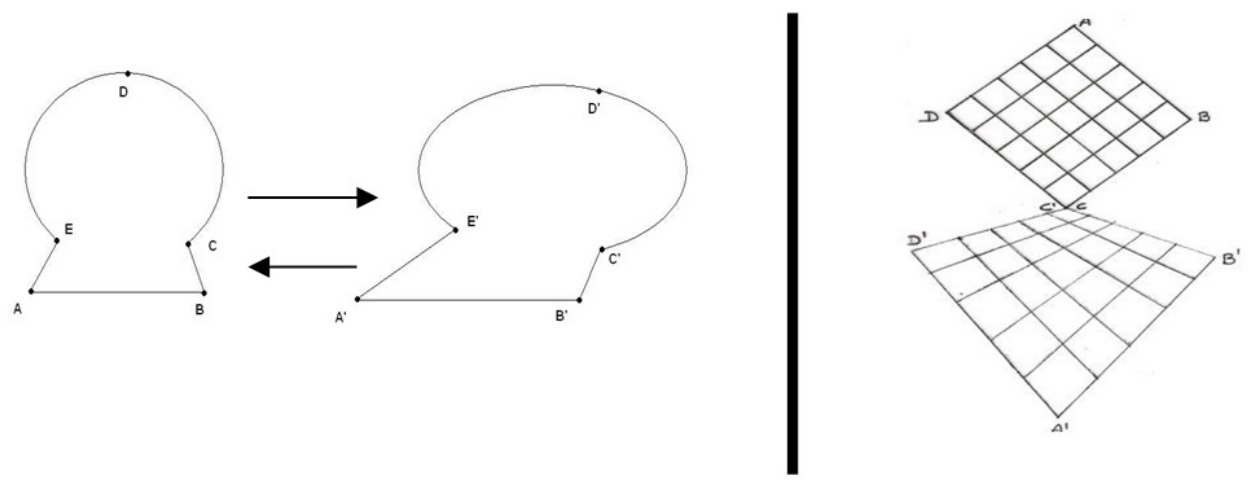

Figura 81. Exemples de projeccions

Algunes projeccions conserven, a més, el paral·lelisme i la proporcionalitat i s'anomenen transformacions afins o afinitats (figura 82).
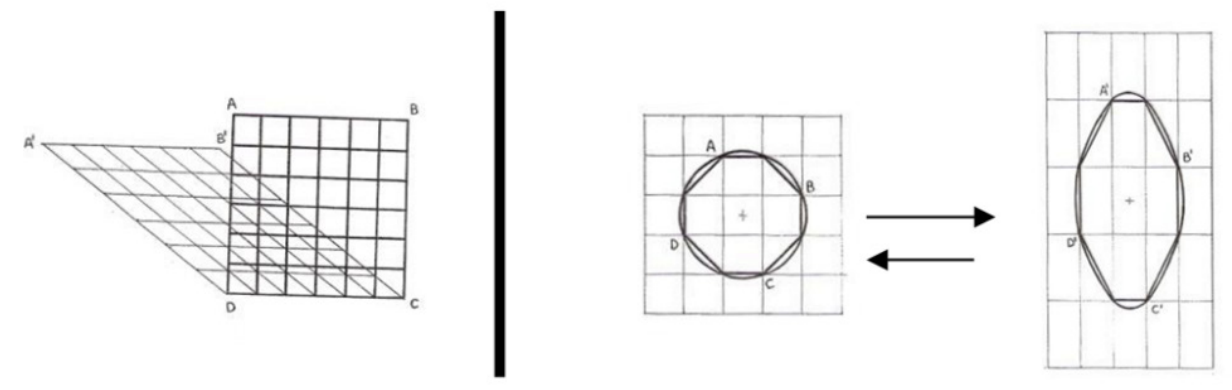

Figura 82. Exemples de transformacions afins

Dins de les afinitats, existeixen projeccions que augmenten o disminueixen la mida de les longituds, però no canvien la forma. Són les anomenades semblances $\mathrm{i}$ en tenim un exemple en el gràfic de la figura 83. 

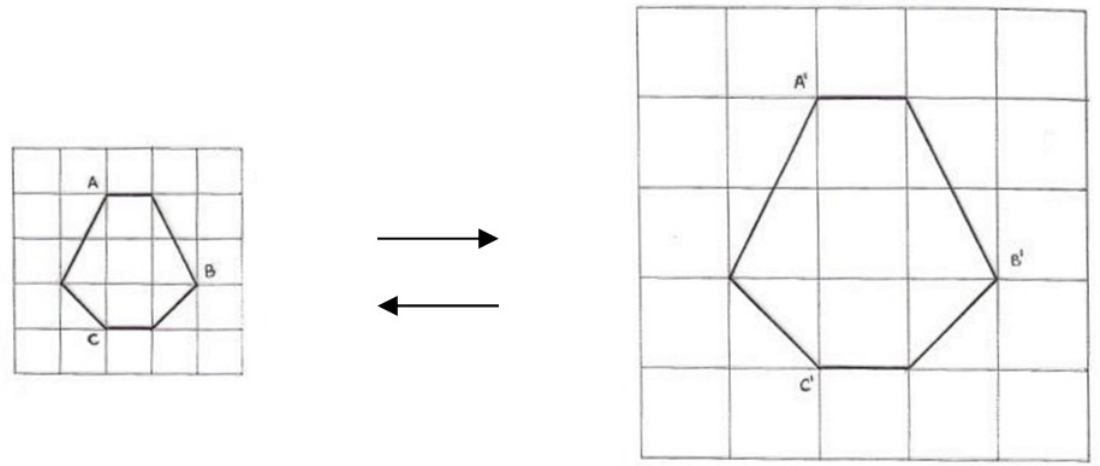

Figura 83. Exemples de semblances

3. Moviments rígids. Si comparem dues figures geomètriques iguals, una al costat de l'altra, podem considerar que s'ha produït un desplaçament. En tenim dos exemples en els gràfics de la figura 84 .
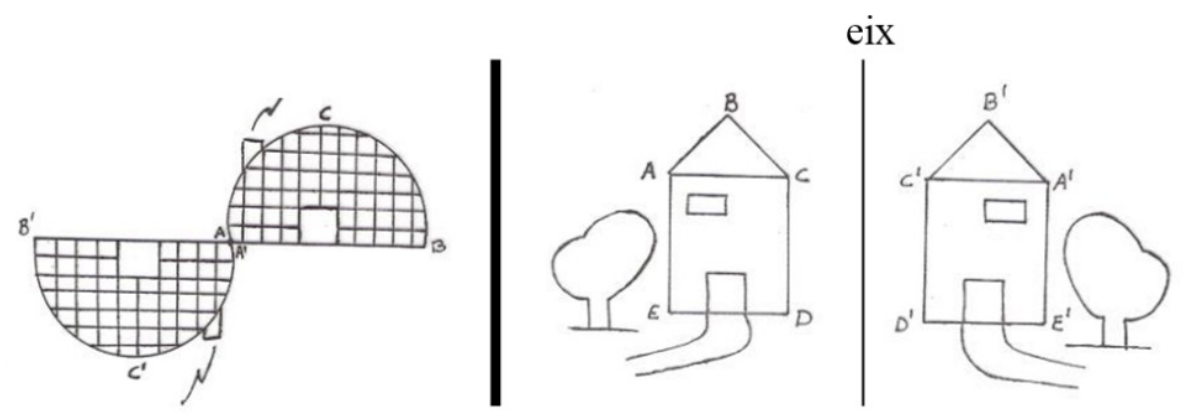

Figura 84: Exemples d'un gir i una simetria axial en figures planes

Observem que totes les dimensions d'una figura i de la seua transformada són iguals. En cada cas podem donar una explicació a l'obtenció de la segona figura, com el resultat de transformar la primera per un moviment rígid en l'espai, a conseqüència del qual hi ha un desplaçament, però no un canvi de dimensions, és per això que aquestes transformacions s'anomenen també isometries. Dins dels moviments rígids podem trobar tres tipus de transformacions diferents: translacions, girs i simetries axials (els gràfics anteriors corresponen als dos darrers).

Si agrupem les diferents propietats de les figures que es conserven en aplicar-los les transformacions, es generen els següents camps d'estudi en la geometria:

\section{Topologia}

És la part de la geometria que estudia les propietats de les figures que es conserven quan se'ls aplica una transformació topològica, és a dir, l'ordre dels punts, l'interior i l'exterior de les figures, si són tancades o obertes i la frontera. 
Aleshores, des del punt de vista topològic, un cercle és equivalent o homòleg a un quadrat, un triangle o un pentàgon..., per exemple. En tres dimensions, una esfera seria topològicament homòloga a un tetràedre o a un cub.

\section{Geometria de les projeccions o projectiva}

Es pot definir com la geometria que s'encarrega d'estudiar les propietats de les figures geomètriques que es mantenen invariants quan se'ls aplica una projecció, és a dir. una transformació projectiva, una transformació afí o una semblança:

- Quan s'aplica una transformació projectiva a una figura geomètrica, les propietats específiques que es mantenen invariants són: el caràcter de línia recta o corba i la convexitat de les figures.

- Quan s'aplica una transformació afí a una figura geomètrica, les propietats específiques que es mantenen invariants són: el paral·lelisme, el punt mig i la proporcionalitat entre segments.

- Quan la transformació que s'aplica a una figura geomètrica és una semblança, les propietats específiques que es conserven són: els angles i, per tant, la forma de la figura.

L'estudi de les propietats invariants abans esmentades es pot considerar de manera global dins de l'anomenada geometria de les projeccions o, de manera individual, donant origen a tres camps geomètrics anomenats geometria projectiva, geometria afí i geometria de la semblança, respectivament.

\section{Geometria euclidiana}

Aquesta branca de la geometria, també anomenada mètrica, s'encarrega d'estudiar les propietats de les figures geomètriques que es mantenen invariants quan se'ls hi aplica un moviment rígid (gir, translació o simetria axial). Les figures homòlogues mantenen invariants les propietats de mesura de longituds $i$, com a conseqüència, de superfícies i volums.

\subsection{Referents psicoevolutius}

Una vegada s'han presentat, a grans trets, les matisacions de les diferents geometries, caldrà recórrer a elles cada vegada que es presente una connexió amb el treball que es farà a les aules escolars i que, en el cas de l'educació infantil, es desenvolupa en el punt 4 d'aquest tema.

Tampoc podem oblidar el moment evolutiu de l'alumnat que tindrem al davant i com respon a l'adquisició dels conceptes geomètrics. Jean Piaget (1896-1980), amb els seus quatre estadis del desenvolupament cognitiu de zero a quinze anys, 
estableix una connexió de la geometria amb la concepció espacial dels xiquets i les xiquetes.

A l'escola començarem estudiant els conceptes de la topologia per a construir l'espai topològic, passant després als de les geometries projectiva i mètrica amb la finalitat de construir els espais projectiu i euclidià, respectivament.

Abans de desenvolupar els continguts i les capacitats geomètriques a l'aula d'infantil, es fa necessari fonamentar matemàticament els conceptes corresponents. Per donar resposta a aquesta necessitat es presenta a continuació una introducció teòrica de tot allò que el docent d'aquesta etapa pot requerir per portar a terme la seua tasca.

\section{Introducció teòrica}

\subsection{Línies en el pla}

Qualsevol línia oberta que es puga traçar és una representació d'una transformada d'una recta o d'alguns dels seues subconjunts. De la mateixa manera, qualsevol línia tancada serà una representació d'una transformada d'una circumferència.

L'expressió analítica d'una recta o una circumferència (amb coordenades, dins d'un sistema de referència) sorgeix de la necessitat de controlar, si més no, aquestes manifestacions de la realitat on, de manera natural, hi apareixen.

Serà, doncs, útil conèixer mínimament aquestes consideracions de caràcter més formal, per a després connectar-les amb el que s'ha d'explicar a l'aula de primària.

\subsubsection{Antecedents: pla, punts i vectors}

Es considera el pla com la porció de l'espai determinada per dues rectes diferents paral·leles o secants, on situarem dos eixos de coordenades perpendiculars (eix X i eix Y, o d'abscisses i d'ordenades, respectivament), i en el qual podem representar totes les figures geomètriques planes, entre d'altres: punt, vector, recta, circumferència..., que són les que estudiarem. És de dimensió dos, precisament per ser dos els eixos necessaris per a determinar-lo, i s'anomena habitualment amb lletres gregues $(\pi, \alpha, \beta \ldots)$. En el pla trobem un punt important en el qual es tallen els dos eixos, que s'anomena origen de coordenades i que es fa correspondre amb la posició del 0 . A partir d'aquest punt, i a intervals de la mateixa longitud, se situen cap a la dreta i cap amunt els nombres enters positius i en els altres sentits els negatius.

Qualsevol punt que es vulga situar en el pla ha de contenir informació ordenada respecte d'aquests dos eixos, primer de X i després de Y (figura 85). 


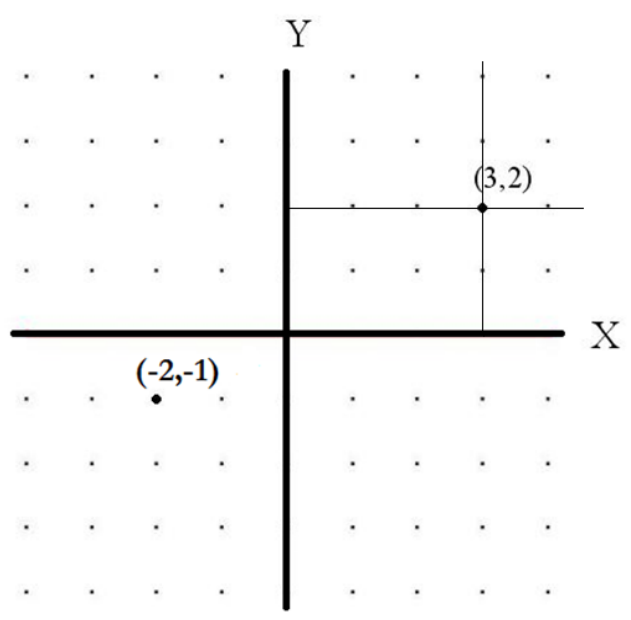

Figura 85. Representació dels eixos de coordenades amb la situació de dos punts

El punt és la mínima figura geomètrica. Analíticament es representa per un parell de nombres separats per una coma i a dintre d'un parèntesi, que són les coordenades del punt. Per exemple, l'origen de coordenades es representaria per $(0,0)$. El primer nombre indica el valor corresponent a l'eix X, i el segon, a l'eix Y. La representació gràfica d'aquest parell de nombres, és una marca petita, que se situarà en la intersecció de dues rectes imaginàries perpendiculars entre si, i paral·leles cadascuna d'elles a un dels eixos, que tallaran l'altre pels valors que hi apareixen al parell de coordenades (per exemple, el $(3,2)$ ). El punt no té grandària, ni forma i, per tant, no es pot deformar per cap transformació geomètrica, sí que es pot desplaçar, però només això. Usualment s'anomena amb una lletra majúscula.

Un vector fix en el pla, $\overrightarrow{A B}$, és un segment orientat que té l'origen en el punt $\boldsymbol{A}$ i

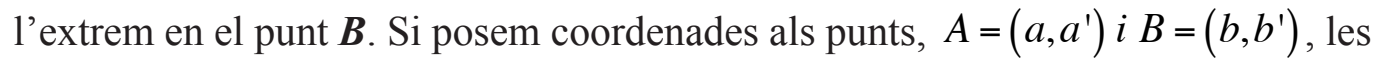
del vector seran $\overrightarrow{A B}=\left(b-a, b^{\prime}-a^{\prime}\right)$.

\section{- Elements d'un vector:}

- Direcció: Es defineix com la recta sobre la qual es troba el vector. Totes les rectes que li són paral·leles tenen la mateixa direcció.

- Sentit: És el del recorregut de la recta quan ens traslladem de $\boldsymbol{A}$ a $\boldsymbol{B}$. És evident que cada direcció admet dos sentits, el de $\boldsymbol{A}$ a $\boldsymbol{B}$ i el de $\boldsymbol{B}$ a $\boldsymbol{A}$. Per tant, la manera de determinar-los serà diferent, així $\overrightarrow{A B}=\left(b-a, b^{\prime}-a^{\prime}\right)$ i anàlogament $\overrightarrow{B A}=\left(a-b, a^{\prime}-b^{\prime}\right)$.

- Mòdul: És la distància entre $\boldsymbol{A}$ i $\boldsymbol{B}$, és a dir, la longitud del segment $\overline{A B}$. Es representa per $|\overrightarrow{A B}|$ i es calcula a partir del teorema de Pitàgores segons: $|\overrightarrow{A B}|=\sqrt{(b-a)^{2}+\left(b^{\prime}-a^{\prime}\right)^{2}}$. Direm que un vector és unitari si el seu mòdul és $\mathbf{1}$. 


\subsubsection{La recta}

Una recta en el pla queda determinada vectorialment per un punt $(\mathbf{a}, \mathbf{b})$ i un vector $(\mathbf{v}, \mathbf{w})$ que marcarà la direcció de la recta i que s'anomena vector director, i usualment s'anomenarà amb una lletra minúscula $(r, s, t . .$.$) . La mateixa recta també$ quedarà determinada si agafem com a vector director el de sentit contrari a l'inicial, (-v,-w).

D'aquesta manera s'observa que en la direcció que determina una recta trobem dos sentits oposats com s'ha comentat amb anterioritat (figura 86).

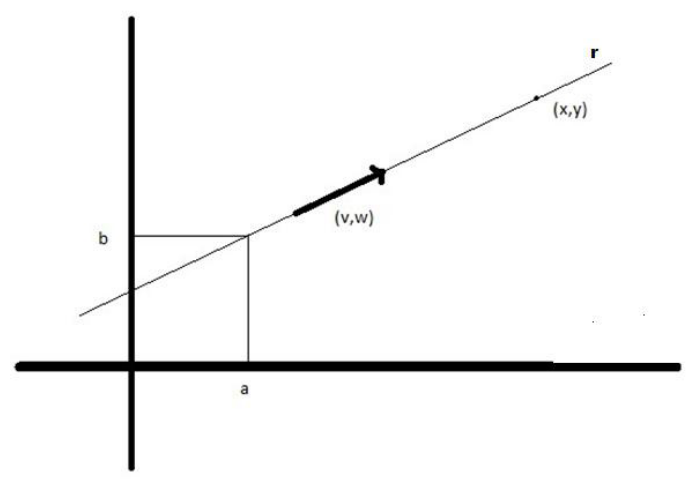

Figura 86. Representació vectorial d'una recta

Qualsevol punt (x,y) de la recta, s'obtindrà traslladant el punt fix (a,b), segons un vector múltiple de $(\mathbf{v}, \mathbf{w})$.

Així:

$$
(\mathrm{x}, \mathrm{y})=(\mathrm{a}, \mathrm{b})+\mathrm{k} \cdot(\mathrm{v}, \mathrm{w}), k \in R
$$

L'expressió anterior s'anomena equació vectorial de la recta, i forma part de la llista completa d'«equacions de la recta» en la qual no entrarem en aquest apartat.

Qualsevol punt d'una recta la divideix en dues semirectes que tenen aquest punt com a origen i que s'anomenen oposades.

Totes les semirectes que tenen origen en un punt donat d'un pla (feix de semirectes) recobreixen aquest i permeten orientar-lo en dos sentits diferents. Si a partir d'una semirecta concreta recorrem el feix seguint el sentit de les agulles del rellotge, s'haurà orientat el pla en un sentit anomenat negatiu. En cas contrari el sentit serà positiu.

Qualsevol parell de punts d'una recta, $\boldsymbol{A}$ i $\boldsymbol{B}$, determina un segment $\overline{A B}$ format per tots els punts de la recta que es troben situats entre $\boldsymbol{A}$ i $\boldsymbol{B}$, i per aquests dos punts (extrems del segment) si és tancat. Si el segment no inclou cap dels extrems és obert i si només n'inclou un és semiobert. En general, quan es parla de segments ens referirem a segments tancats. 
La longitud d'un segment $\overline{A B}$ es calcula mesurant la distància entre els seus extrems i es representa per $|\overrightarrow{A B}|=\mathrm{d}(A, B)$, tal com s'ha especificat al cas dels vectors en el punt 3.1.1.

La recta perpendicular a un segment pel punt mig del mateix s'anomena mediatriu.

Dos segments qualssevol poden tenir o no punts en comú. Direm que dos segments són concatenats quan tenen un extrem comú, i són consecutius quan tenen un extrem comú i estan alineats.

Si considerem dues línies rectes al pla, les posicions relatives que hi poden tenir són:

1. Rectes secants: tenen sols un punt en comú. Analíticament $r \cap s=\{P\}$ (figura 87).

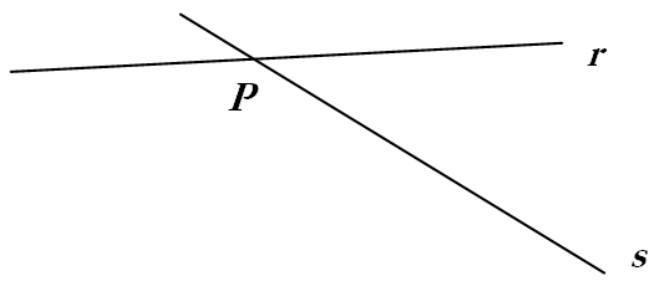

Figura 87. Representació de rectes secants en el pla

2. Rectes paral·leles no coincidents: no tenen cap punt en comú. Analíticament $r \cap s=\Phi$ (figura 88).

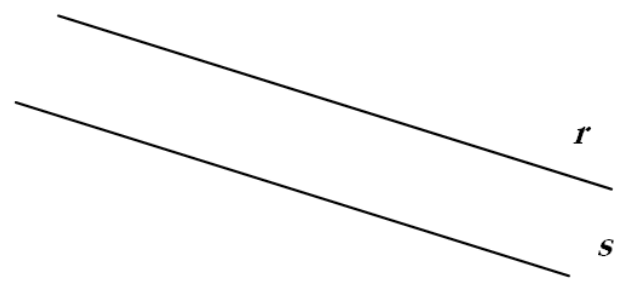

Figura 88. Representació de rectes paral·leles no coincidents

3. Rectes paral $\cdot$ leles coincidents: tenen tots els punts comuns. Analíticament $r \cap s=r=s$ (figura 89).

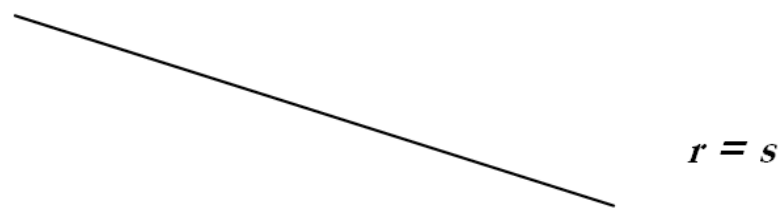

Figura 89. Representació de rectes paral·leles coincidents 
Nota: Si considerem dues línies rectes en l'espai, caldria afegir un nou cas als tres precedents: Rectes que es creuen en l'espai, tampoc tenen punts en comú i no pertanyen al mateix pla. Analíticament $r \cap s=\Phi$ (figura 90).

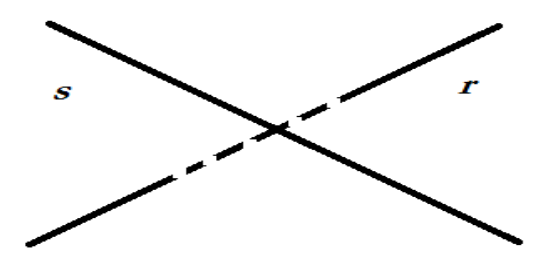

Figura 90. Representació de rectes que es creuen en l'espai

\subsubsection{La circumferència}

Definim circumferència com el lloc geomètric de tots els punts del pla que equidisten d'un fix anomenat centre. Aquesta distància fixa s'anomena radi. Cal notar que amb la paraula radi, ens referim també a cadascun dels segments que uneixen el centre amb un punt qualsevol de la circumferència (figura 91).

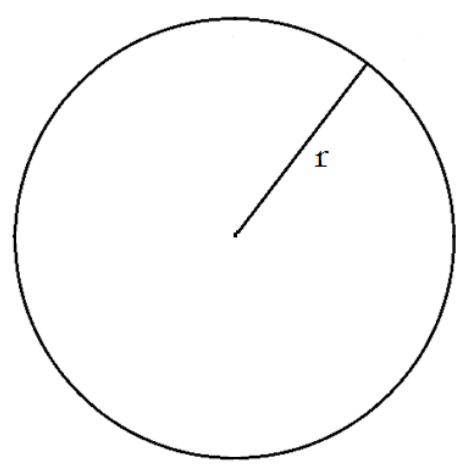

Figura 91. Representació d'una circumferència i d'un dels seus radis

Definim a continuació alguns dels seus elements bàsics:

- Corda: segment que uneix dos punts qualssevol de la circumferència.

- Diàmetre: corda que passa pel centre de la circumferència.

- Arc: tram o porció de la circumferència comprés entre dos dels seus punts. Quan els punts són els extrems d'un diàmetre, l'arc és una semicircumferència.

Quan calga calcular la longitud d'una circumferència de radi $\boldsymbol{r}$, utilitzarem l'expressió $L=2 \cdot \pi \cdot r$.

Si es considera una circumferència $\mathrm{i}$ una recta, les posicions relatives que poden tenir en el pla són les següents (figura 92): 
a) Recta tangent: la recta i la circumferència sols tenen un punt en comú.

b) Recta secant: la recta i la circumferència tenen dos punts en comú.

c) Recta exterior: la recta i la circumferència no tenen punts en comú.

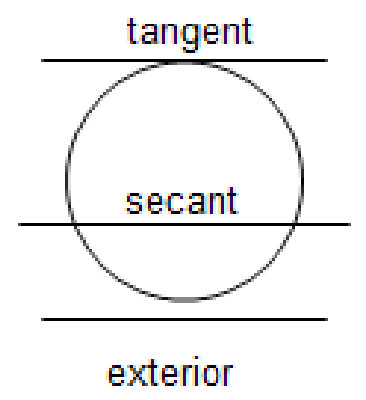

Figura 92. Representació de les posicions relatives d'una circumferència i una recta en el pla

De tots els tipus de línies que podem trobar en el pla, ens interessen particularment les obertes i les tancades simples (aquelles que no tenen cap punt per on la línia passa dues vegades). En el cas de les obertes, el principi i el final són dos punts diferenciats, mentre que en les tancades, són el mateix punt. En general, obtindrem línies obertes simples en aplicar una transformació topològica a una recta, una semirecta o un segment, i línies tancades simples en aplicar-la a una circumferència.

\subsection{Superfícies en el pla}

Una superfície plana és una figura geomètrica que resulta de considerar una part del pla determinada per línies d'aquest. En particular, qualsevol recta d'un pla el divideix en dues regions anomenades semiplans que inclouen la recta.

Una superfície plana és convexa (figura 93) quan conté tots els segments que uneixen qualsevol parell de punts d'aquesta. I còncava (figura 94) quan algun d'aquests segments no està contingut en la superfície.

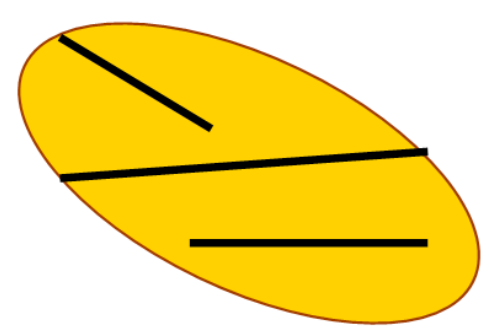

Figura 93. Representació d'una superfície plana convexa 


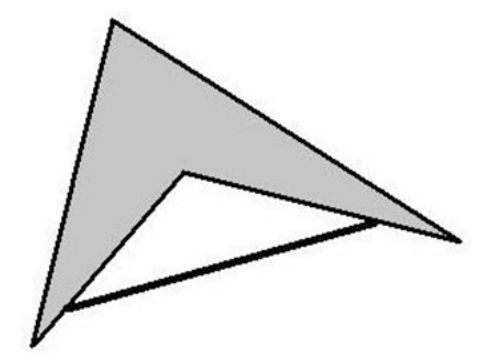

Figura 94. Representació d'una superfície plana còncava

\subsubsection{Angles}

Les primeres superfícies planes que s'han d'estudiar són les anomenades angles.

Quan dues rectes són secants, defineixen quatre regions en el pla. Es denomina angle a cadascuna d'aquestes regions, incloent-hi les semirectes d'origen comú que les defineixen. A aquest origen se l'anomena vèrtex i les semirectes són els costats de l'angle (figura 95).

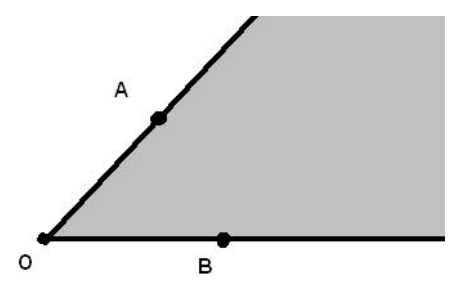

Figura 95. Representació d'una regió angular

Simbolitzem l'angle de dues maneres diferents: mitjançant només el vèrtex, $\hat{O}$, o bé amb una terna de punts composta per un punt de cada costat de l'angle i el seu vèrtex, $A \hat{O} B$.

Quan les quatre regions són iguals, els angles s'anomenen rectes, i la seua amplitud angular és de $90^{\circ}$. Quan les semirectes que determinen l'angle són oposades, aquest es denomina angle pla. La seua amplitud és igual a dos angles rectes, és a $\operatorname{dir}, 180^{\circ}$.

Els angles que tenen una amplitud menor que el recte s'anomenen aguts.

Els angles la amplitud dels quals està compresa entre un angle recte i un angle pla, es denominen obtusos.

Quan les dues semirectes que determinen l'angle són coincidents, l'angle que es forma s'anomena complet. La seua amplitud és igual a quatre angles rectes, és a $\operatorname{dir}, 360^{\circ}$. 
Aquests cinc tipus d'angles són convexos. Seran còncaus la resta d'angles, és a dir, els que mesuren més de $180^{\circ}$ i menys de $360^{\circ}$.

Dos angles seran complementaris quan la suma de les seues amplituds siga igual a $90^{\circ}$; seran suplementaris quan sumen $180^{\circ}$ i conjugats quan sumen $360^{\circ}$.

En qualsevol angle, s'anomena bisectriu la semirecta continguda en ell que té l'origen en el vèrtex de l'angle i el divideix en dues parts iguals.

\subsubsection{Polígons}

Definim línia poligonal com una col·lecció de segments concatenats no consecutius.

Una línia poligonal serà simple (figura 96) si no hi ha cap punt diferent dels extrems dels segments que pertanya a dos d'ells a la vegada. En cas contrari, es diu no simple (figura 97).

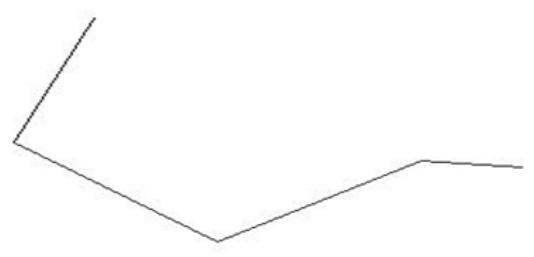

Figura 96. Representació d'una línia poligonal simple

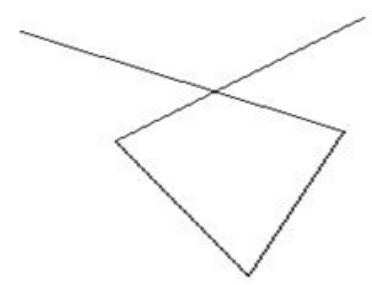

Figura 97. Representació d'una línia poligonal no simple

En una línia poligonal de més de dos segments, si el primer i darrer tenen un extrem comú, aquesta serà tancada. En cas contrari serà oberta.

A partir d'aquests conceptes, definim polígon com la porció del pla limitada per una línia poligonal tancada simple, incloent-hi aquesta línia.

Cada segment de la línia poligonal s'anomena costat del polígon i si sumem les longituds de tots els costats d'un polígon, obtenim el seu perímetre. Els extrems dels costats son els vèrtexs del polígon. El segment que uneix dos vèrtexs no consecutius d'un polígon és una diagonal d'aquest. 
Anomenarem els costats d'un polígon amb lletres minúscules: $a, b, c . . . ;$ i els vèrtexs amb lletres majúscules: A, B, C... En el cas dels triangles, s'acostuma a utilitzar la mateixa lletra per a un costat i per al vèrtex oposat.

Les semirectes que contenen dos costats concurrents d'un polígon i que tenen l'origen en el vèrtex comú a aquests costats determinen dos angles (figura 98). L'angle que conté el polígon s'anomena angle interior del polígon. Usualment es denominen angles del polígon els angles interiors del mateix.

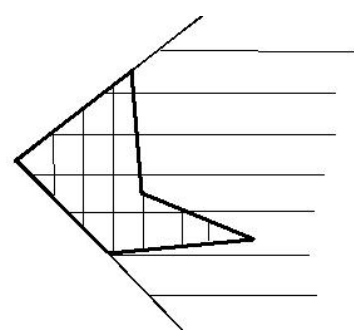

Figura 98. Representació d'un angle interior d'un polígon

Un polígon és equilàter quan té tots els costats de la mateixa longitud. Es diu equiangle quan els angles interiors tenen la mateixa amplitud, i és regular quan és equilàter $\mathrm{i}$ equiangle. Els polígons regulars tenen en l'interior un punt equidistant de tots els vèrtexs que s'anomena centre del polígon.

Els polígons s'anomenen pel nombre dels costats o angles que tenen. Així, trobem triangles, quadrilàters, pentàgons, hexàgons, heptàgons, octògons, enneàgons $\mathrm{o}$ nonàgons, decàgons, hendecàgons (endecágonos en castellà), dodecàgons...

A continuació, estudiem més detalladament alguns polígons, per la rellevància que tenen a les aules d'infantil i primària, donada la gran quantitat d'aproximacions a ells que trobem en els objectes reals de l'entorn.

\subsubsection{Triangles}

Un triangle és un polígon determinat per una línia poligonal simple tancada de tres segments. Tindrà, per tant, tres costats, tres angles i tres vèrtexs.

Podem anomenar els triangles en funció dels seus angles i dels seus costats.

Si atenem els angles, la denominació produeix la següent classificació:

A. Triangles acutangles, són els que tenen els tres angles aguts (figura 99).

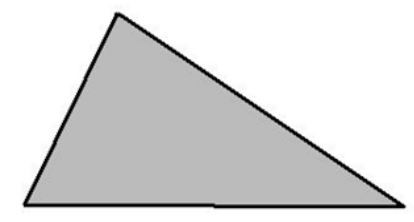

Figura 99. Representació d'un triangle acutangle 
B. Triangles rectangles, són els que tenen un angle recte (figura 100). Els costats que determinen l'angle recte es diuen catets i el tercer costat, hipotenusa.

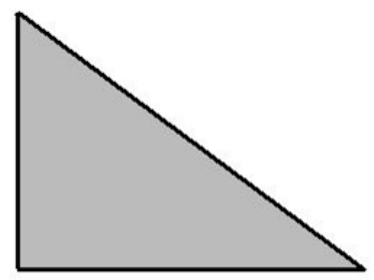

Figura 100. Representació d'un triangle rectangle

C. Triangles obtusangles, un dels tres angles és obtús (figura 101).

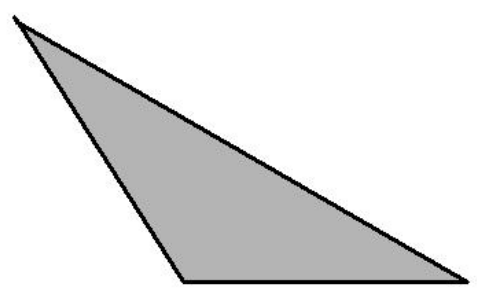

Figura 101. Representació d'un triangle obtusangle

Si atenem els costats, les denominacions són:

A. Triangles equilàters, són aquells que tenen els tres costats d'igual longitud (figura 102).

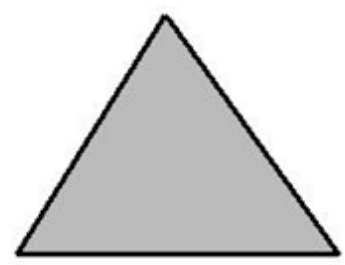

Figura 102. Representació d'un triangle equilàter

B. Triangles isòsceles, tenen dos costats d'igual longitud (figura 103).
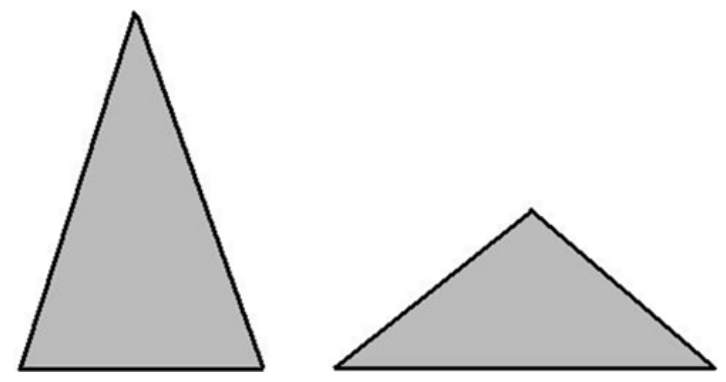

Figura 103. Representació de dos triangles isòsceles 
C. Triangles escalens, els tres costats tenen diferent longitud (figura 104).

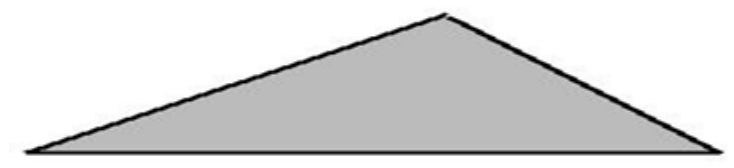

Figura 104. Representació d'un triangle escalè

Si ens fixem en els costats dels triangles en podem obtenir dues classificacions diferents. Una seria excloent i l'altra inclusiva. La classificació excloent és aquella que presenta tantes classes d'equivalència (vegeu 2.4 del tema 1) com denominacions diferents n'hi ha. La inclusiva permet que en una mateixa classe puga haver-hi elements corresponents a més d'una denominació. La diferència es troba en la manera de definir els elements.

Per exemple: si es diu que «els triangles isòsceles són aquells que només tenen dos costats iguals», un triangle equilàter no és isòsceles. Per tant, l'hem exclòs. És a dir, aconseguim una classificació excloent dels triangles que es pot representar de la següent manera:

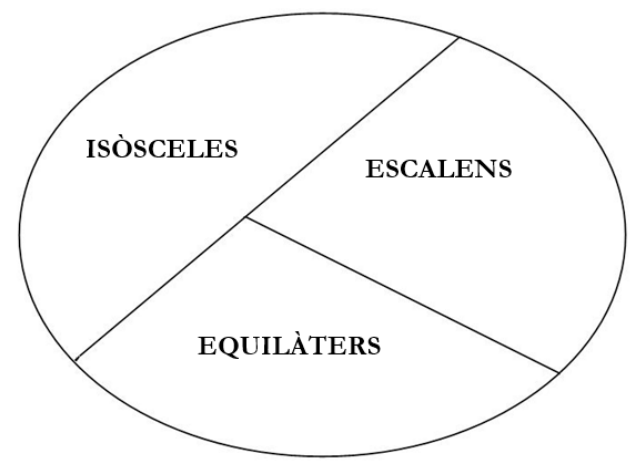

Però si la definició considerada és «els triangles isòsceles són aquells que tenen almenys dos costats iguals», un triangle equilàter sí que és isòsceles. Per això, aquest tipus de classificació s'anomena inclusiva, perquè inclou. En aquest cas, obtenim dues classes d'equivalència, la dels triangles que tenen alguns costats iguals i la dels que els tenen tots diferents, és a dir, la dels isòsceles, que conté els equilàters com a subconjunt, i la dels escalens, respectivament:

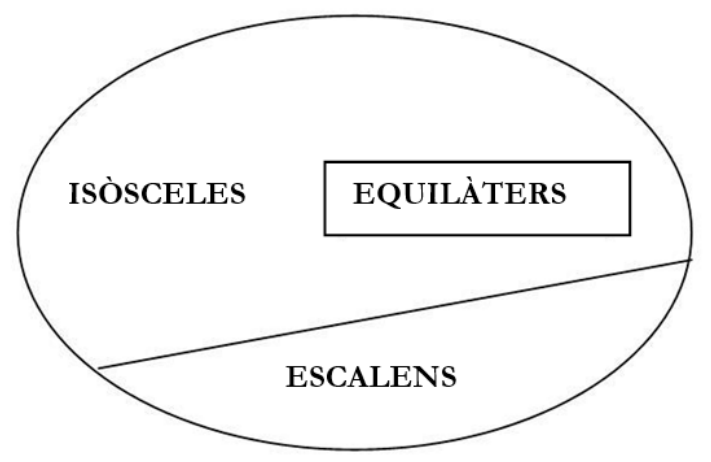




\subsubsection{Quadrilàters}

Un quadrilàter és un polígon determinat per una línia poligonal simple tancada de quatre segments. Tindrà, per tant, quatre costats, quatre vèrtexs i quatre angles.

Hi ha diferents tipus de quadrilàters. Segons les característiques que hi considerem per cadascun d'ells, obtindrem diferents classificacions.

Així, si atenem el paral lelisme dels costats trobem tres grans classes de quadrilàters: paral lelograms (tenen els dos parells de costats oposats paral·lels), trapezis (tenen sols un parell de costats oposats paral·lels, que s'anomenen bases) i trapezoides (no tenen cap costat paral·lel a un altre).

Els quadrilàters que componen cadascuna d'aquestes classes es poden determinar per les següents definicions:

A. Paral·lelograms. En funció de la igualtat dels costats i/o dels angles, obtenim les quatre subclasses següents:

A.1. Quadrats (figura 105).

- Els quatre angles són d'igual amplitud (equiangle). I, a més, són de $90^{\circ}$.

- Els quatre costats són d'igual longitud (equilàter).

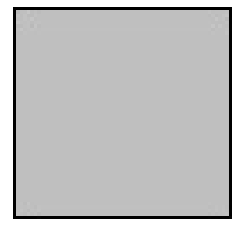

Figura 105. Representació d'un quadrat

A.2. Rectangles (figura 106).

- Els quatre angles són d'igual amplitud (equiangle). I, a més, són de $90^{\circ}$.

- Els costats oposats són d'igual longitud. Els concurrents no ho són.

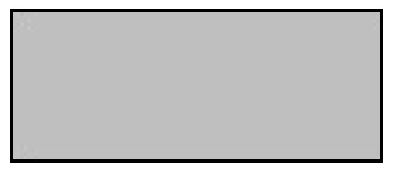

Figura 106. Representació d'un rectangle

A.3. Rombes (figura 107).

- Els angles oposats són de la mateixa amplitud. Els no oposats no ho són.

- Els quatre costats són d'igual longitud (equilàter).

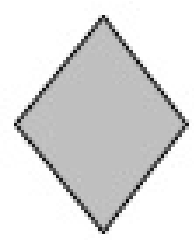

Figura 107. Representació d'un rombe 


\section{A.4. Romboides (figura 108).}

- Els angles oposats són de la mateixa amplitud. Els no oposats no ho són.

- Els costats oposats són d'igual longitud. Els concurrents no ho són.

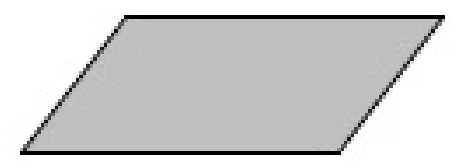

Figura 108. Representació d'un romboide

B. Trapezis. En funció de la igualtat dels costats i/o dels angles, obtenim les dues subclasses següents:

B.1. Trapezis isòsceles (figura 109).

- Les longituds dels costats no paral·lels són iguals.

- Els angles que comparteixen un mateix costat bàsic són iguals dos a dos.

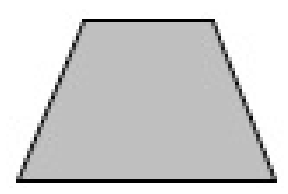

Figura 109. Representació d'un trapezi isòsceles

B.2. Trapezis escalens (figura 110).

- Les longituds dels costats no paral·lels són diferents.

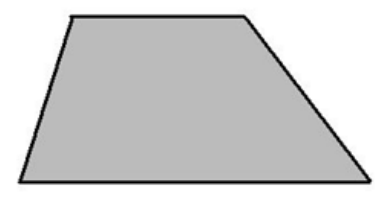

Figura 110. Representació d'un trapezi escalè

Quan en un trapezi escalè un dels costats no paral·lels és perpendicular a les bases, s'anomena trapezi rectangle (figura 111).

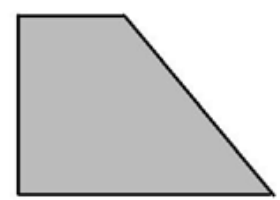

Figura 111. Representació d'un trapezi rectangle

C. Trapezoides. No tenen cap costat paral·lel a cap altre i no s'exigeix igualtat de costat ni d'angles (figura 112).

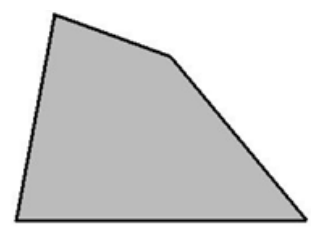

Figura 112. Representació d'un trapezoide 
Amb aquestes definicions s'aconsegueix una classificació excloent dels quadrilàters, que es pot representar de la següent manera:

\begin{tabular}{|c|c|c|} 
PARAL·LELOGRAMS & TRAPEZIS & \\
\hline QUADRATS & T. ISÒSCELES & \\
\hline RECTANGLES & & TRAPEZOIDES \\
\hline ROMBES & T. ESCALENS & \\
\hline ROMBOIDES & & \\
\hline
\end{tabular}

Si es vol obtenir una classificació inclusiva dels paral·lelograms hem d'incorporar alguns canvis en les definicions anteriors. Per a facilitar la comprensió de la nova classificació, ens inclinem per mantenir les tres grans classes de la classificació inicial dels quadrilàters, modificar les definicions dels paral-lelograms i deixar sense canvis les dels trapezis i trapezoides.

Així considerarem:

- Romboide com el quadrilàter que té els costats oposats d'igual longitud.

- Rombe com el que té els quatre costats d'igual longitud.

- Rectangle com el que té els quatre angles rectes.

- Quadrat com el que té els quatre costats d'igual longitud i els quatre angles rectes.

Segons les definicions exposades, la idea general de paral·lelogram s'identifica amb el concepte de romboide. A més, els quadrats estan inclosos en les classes de rectangles i de rombes. Aleshores, la representació gràfica d'aquesta classificació inclusiva serà:

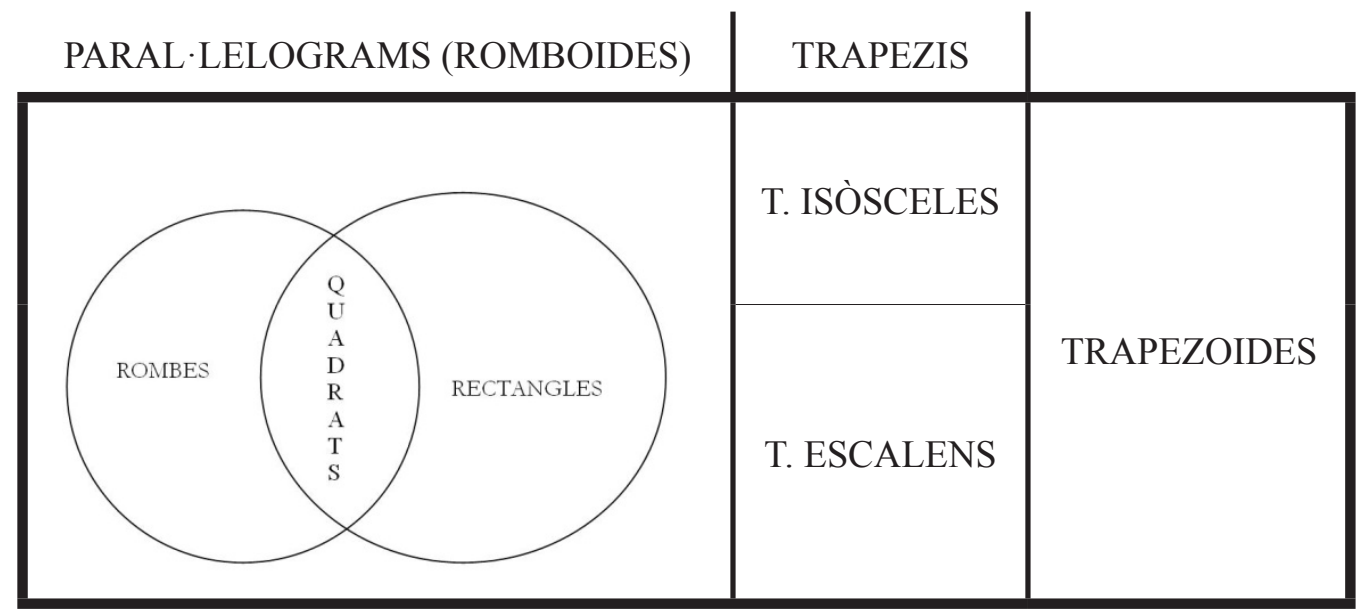




\subsubsection{Pentàgons}

Un pentàgon és un polígon determinat per una línia poligonal simple tancada de cinc segments. Tindrà, per tant, cinc costats, cinc angles i cinc vèrtexs. Podem considerar pentàgons regulars i irregulars. Encara que habitualment s'associa la idea d'aquest polígon a un pentàgon regular, hem de tenir en compte que hi ha també altres pentàgons que no ho són, tant convexos com còncaus (figura 113).
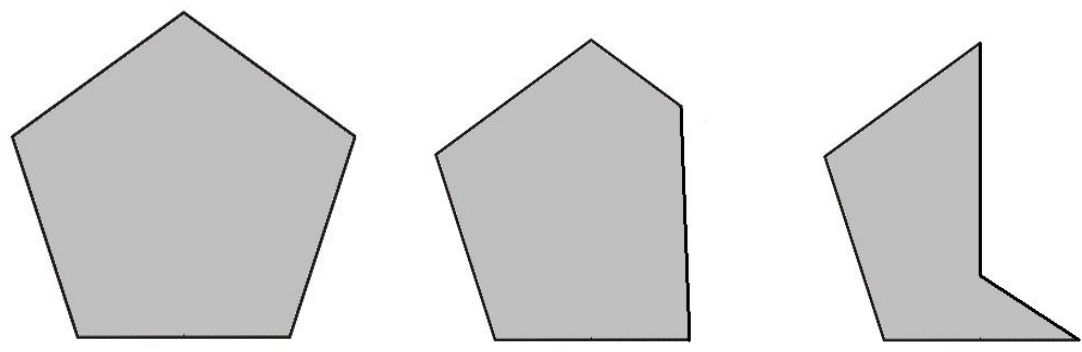

Figura 113. Representació de pentàgons: regular convex (esquerra), irregular convex (centre) i irregular còncau (dreta)

El pentàgon regular ha estat molt utilitzat al llarg de la història en els àmbits de la construcció, la religió, les creences i l'art.

Les rectes que contenen els costats del pentàgon regular es tallen en punts exteriors,,determinant una figura que s'anomena pentacle (figura 114) i que correspon al tipus de polígons coneguts com estrellats. Si unim els punts de tall esmentats trobem un nou pentàgon.

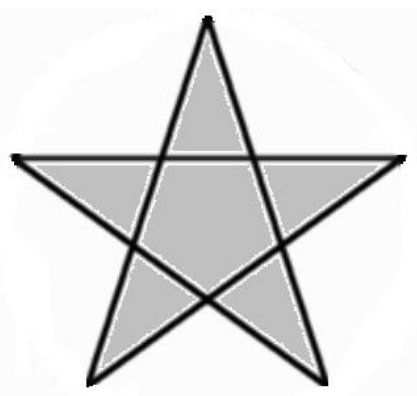

Figura 114. Representació d'un pentacle

En l'art, el pentacle també s'ha utilitzat durant tota la història. Un dels casos més significatius, és el quadre de Dalí, Leda atòmica de 1949, on l'harmonia de les formes s'aconsegueix per la inscripció de totes les figures en un pentacle regular, com es mostra en la figura 115. 

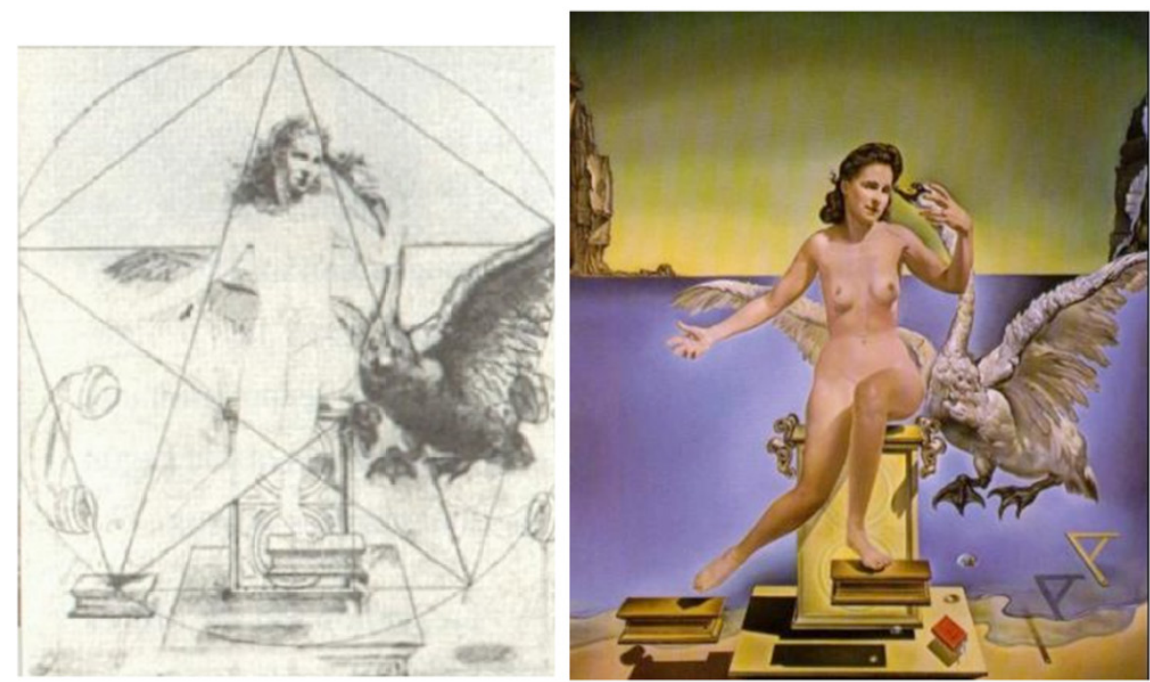

Figura 115. Representació de l'esbós i del quadre Leda atòmica de Dalí, 1949

\subsubsection{Hexàgons}

Un hexàgon és un polígon determinat per una línia poligonal simple tancada de sis segments. Tindrà, per tant, sis costats, sis angles i sis vèrtexs. Podem considerar hexàgons regulars i irregulars. Encara que habitualment s'associa la idea d'aquest polígon a un hexàgon regular, hem de tenir en compte que hi ha també altres hexàgons que no ho són, tant convexos com còncaus (figura 116).
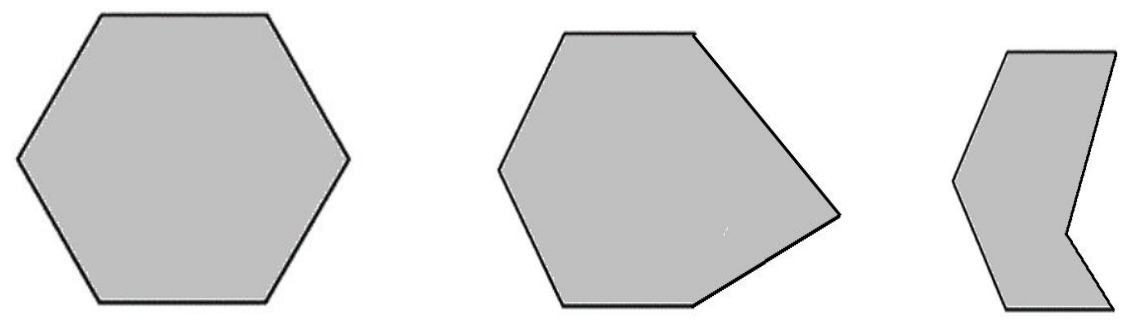

Figura 116. Representació d'hexàgons: regular convex (esquerra), irregular convex (centre) i irregular còncau (dreta)

Una característica que es repeteix en tots els polígons regulars és que es poden dividir en triangles isòsceles iguals unint el centre amb tots els vèrtexs del polígon. Particularment, en l'hexàgon regular, aquests triangles són equilàters (figura 117).

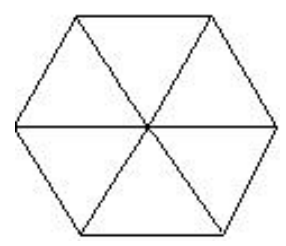

Figura 117. Representació d'un hexàgon regular dividit en triangles equilàters 
L'hexàgon és un polígon amb molta presència en la natura. La imatge més comuna és la xarxa de cel·les de secció hexagonal que formen les abelles als ruscs o les facetes dels ulls d'alguns insectes (figura 118).
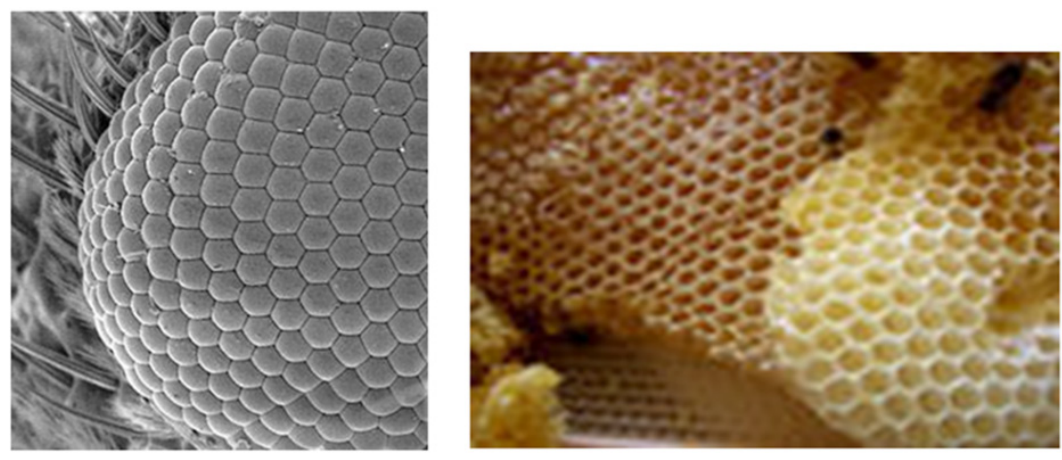

Figura 118. Representació de formes hexagonals a la natura: facetes de l'ull d'un insecte ( esquerra), ruscs d'abelles (dreta)

En l'àmbit de la química, l'hexàgon apareix també en moltes de les formes en les quals el carboni es presenta en la natura, en particular la coneguda com carboni 60, que presenta una estructura tridimensional semblant a la d'un baló de futbol, com la que es mostra a la figura 119.

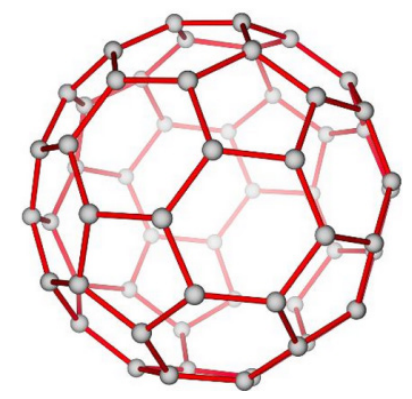

Figura 119. Representació de l'estructura tridimensional del carboni 60 (imatge proporcionada per www.pdm.com.co)

Una vegada estudiats els exemples de polígons amb un nombre parell i imparell de costats es fa innecessari detenir-se en l'estudi detallat de polígons amb més costats, atés que els conceptes vistos fins ara es repeteixen de manera semblant.

\subsubsection{Consideracions sobre els polígons}

\subsubsection{Mosaics}

Els mosaics són imatges compostes per peces, que tradicionalment han estat utilitzats en l'art. El seu origen se situa en construccions de civilitzacions antigues (Grècia, Roma, figura 120) i posteriorment s'han trobat també en altres cultures, sent una tècnica que ha arribat fins als nostres dies. 


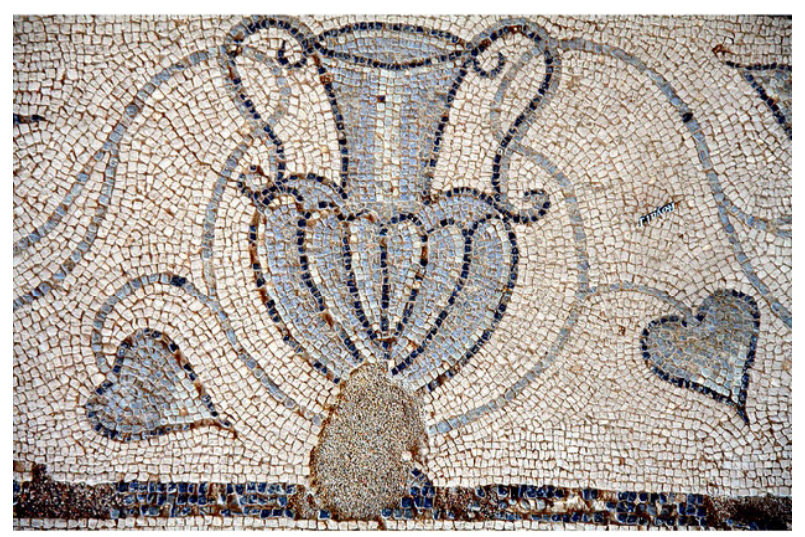

Figura 120. Imatge d'un mosaic romà a Carranque: La Casa de Materno (proporcionada per flickr.com)

Estan compostos per peces de ceràmica o vidre, l'objectiu de les quals és formar una figura plana sense deixar cap fragment de superfície per cobrir. Cadascuna d'aquestes peces s'anomena tessel·la.

Matemàticament, s'han estudiat els possibles recobriments del pla quan les tesselles són polígons regulars. Les conclusions d'aquest estudi són:

1. Si utilitzem polígons regulars d'un sols tipus, les xarxes que es poden obtenir són les que es mostren en la figura 121.
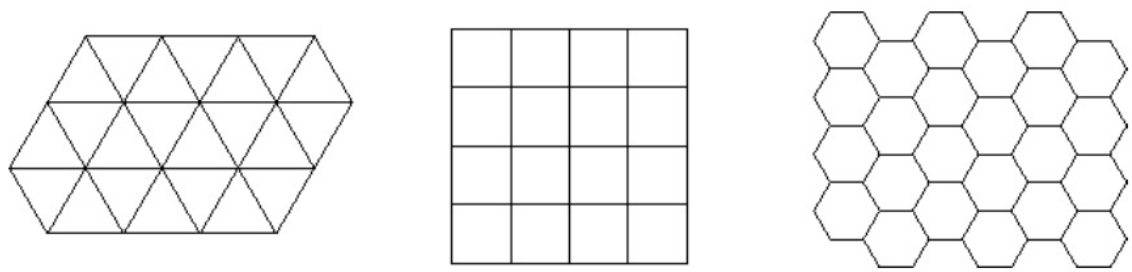

Figura 121. Xarxes de tessel·les d'un sol polígon: triangle equilàter (esquerra), quadrat (centre) i hexàgon regular (dreta)

Cal notar que només es troben aquestes tres xarxes perquè per a recobrir el pla és necessari que en un punt donat els angles dels polígons que concorren sumen $360^{\circ}$ i això només passa amb aquests tres polígons regulars.

2. Si s'utilitza més d'un tipus de polígon regular, sols s'acompleix la condició anterior en els casos de les combinacions de la figura 122.
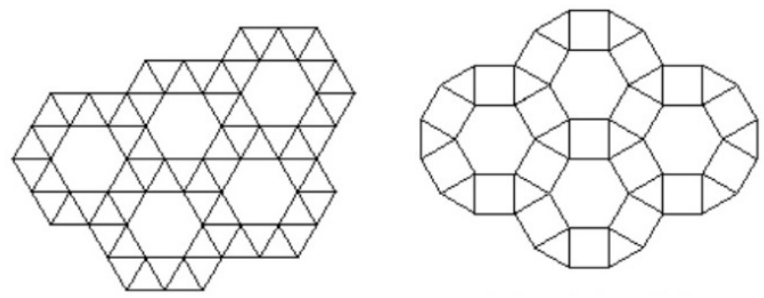

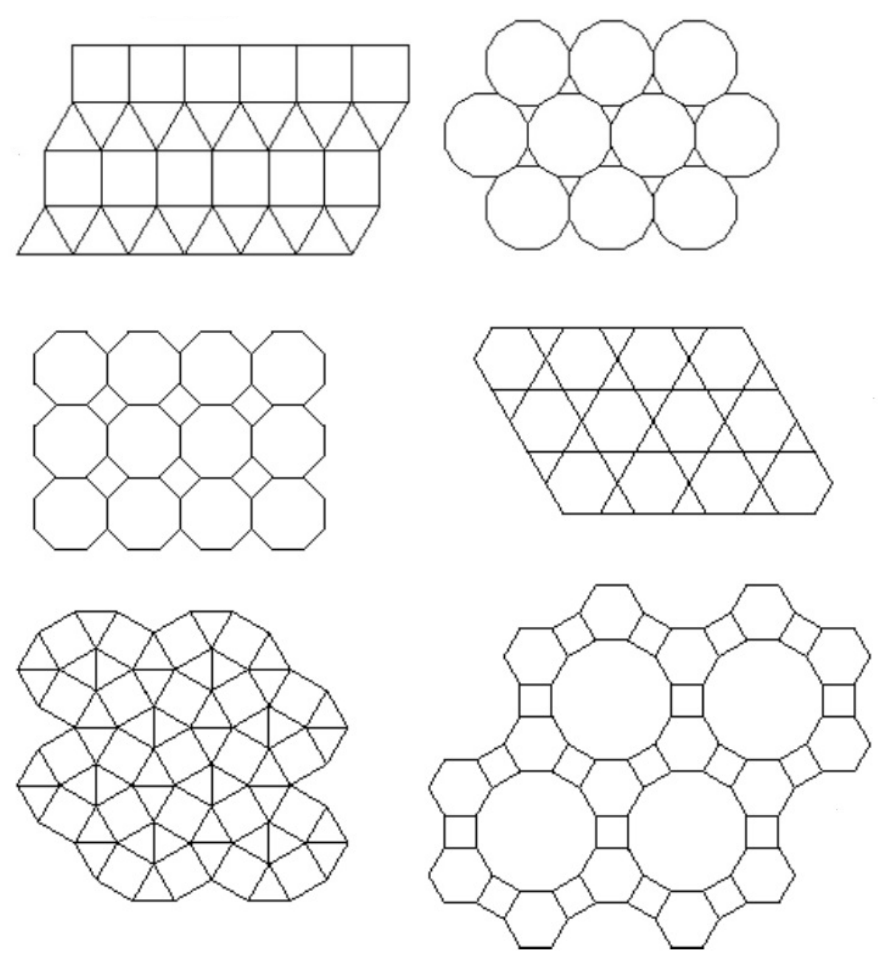

Figura 122. Xarxes de tessel·les amb formes de diferents polígons regulars

\subsubsection{Polígons regulars: simetries}

Una figura serà simètrica quan, a partir d'un eix de simetria, es desenvolupe d'igual manera a cadascun dels seus costats. L'eix de simetria és una recta que no existeix en la realitat, però que la podem imaginar. Els polígons regulars, per ser equilàters i equiangles, tenen igual nombre d'eixos de simetria que de costats. Les dues figures següents ens serviran per a il·lustrar els casos generals:

1. Quan el nombre de costats és imparell, els eixos de simetria són les bisectrius dels angles interns, que passen pel punt mig dels costats oposats al vèrtex de cada angle. Com que hi ha tants angles com costats, el nombre d'eixos de simetria coincideix amb el de costats. Un exemple pel cas d'un triangle equilàter el trobem en la figura 123.

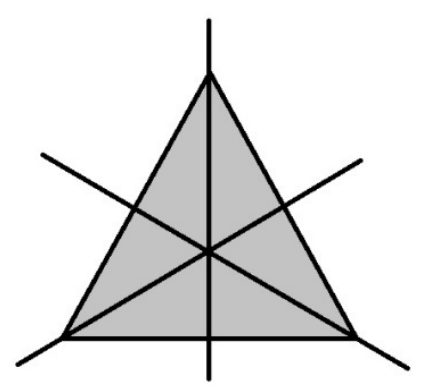

Figura 123. Representació dels eixos de simetria d'un triangle equilàter 
2. Quan el nombre de costats és parell, hi ha dos tipus d'eixos de simetria. Les bisectrius dels angles interns, que en aquest cas coincideixen per cada parell d'angles oposats, i les rectes que passen pels punts mitjans de cada parell de costats oposats. Per aquest fet, el nombre d'eixos de simetria que són bisectrius, serà la meitat del nombre d'angles del polígon i el nombre d'eixos de simetria que passen pel centre dels costats oposats, serà la meitat del nombre de costats. Si sumem aquestes dues quantitats, obtindrem el nombre total d'eixos, que coincidirà novament amb el nombre de costats. Un exemple pel cas d'un quadrat, el trobem en la figura 124.

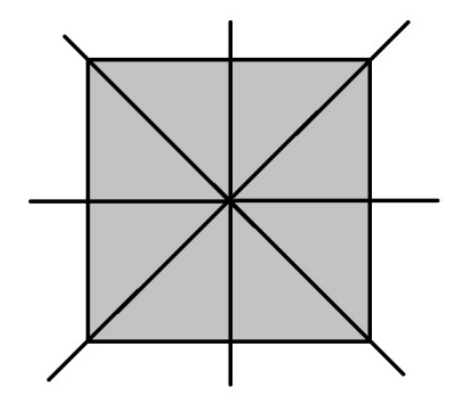

Figura 124. Representació dels eixos de simetria d'un quadrat

Quan el polígon no és regular, no es pot garantir el nombre d'eixos de simetria, però això no nega que en tinga.

\subsubsection{Cercle}

Definim cercle com la porció del pla limitada per una circumferència, incloent-hi també aquesta línia. També es podria definir com el lloc geomètric dels punts del pla la distància dels quals a un punt anomenat centre, $\boldsymbol{C}$, és menor o igual que un valor $\boldsymbol{r}$, anomenat radi.

Per a calcular l'àrea d'un cercle, utilitzarem l'expressió $A=\pi \cdot r^{2}$.

Tenint en compte les definicions dels elements bàsics de la circumferència incloses en el punt 3.1.3, podem definir algunes superfícies notables relacionades amb el cercle:

- Angle central: és el que determinen dues semirectes que contenen dos radis $i$ té el vèrtex en el centre del cercle (figura 125). Cal adonar-se que hi ha dos angles centrals representats en la figura: el que es troba ombrejat és convex i el seu conjugat, en blanc, que és còncau.

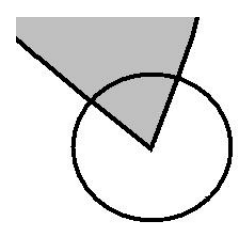

Figura 125. Representació d'un angle central 
- Sector circular: és la intersecció d'un cercle amb qualsevol angle central del mateix (figura 126). Quan l'angle central és un angle pla el sector circular és un semicercle.

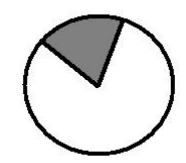

Figura 126. Representació d'un sector circular

- Segment circular: és la porció de cercle compresa entre una corda i l'arc corresponent (figura 127). Qualsevol corda determina dos segments circulars, ja que els seus extrems delimiten dos arcs en la circumferència. Quan la corda és un diàmetre, el segment circular s'anomena semicercle, que també es pot definir com la porció de cercle compresa entre una semicircumferència i el diàmetre que la defineix.

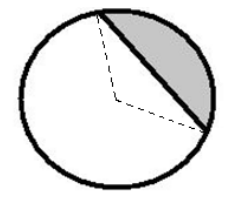

Figura 127. Representació dels dos segments circulars d'un cercle determinats per la mateixa corda

- Corona circular: és la porció del pla delimitada per dues circumferències concèntriques (figura 128).

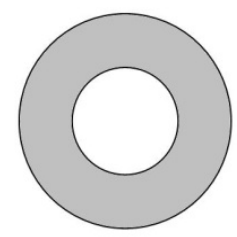

Figura 128. Representació d'una corona circular

\subsection{Figures en l'espai}

Com s'ha comentat en el punt 3.1.1, dues rectes secants determinen un pla. Si es considera una tercera recta no coplanària $\mathrm{amb}$ aquestes $\mathrm{i}$ que siga perpendicular a les dues, apareix una nova dimensió que completa les que ja tenia el pla. Aquestes tres dimensions configuren l'ens geomètric anomenat espai, que és el conjunt de tots els punts existents, introduït en el punt 2.1.

Qualsevol pla de l'espai el divideix en dues regions anomenades semiespais, que inclouen el pla. 


\subsubsection{Angles en l'espai}

Si considerem dos plans en l'espai, les posicions que hi poden tenir són:

1. Plans secants: tenen només una recta en comú (figura 129). Analíticament $\pi_{1} \cap \pi_{2}=r$.

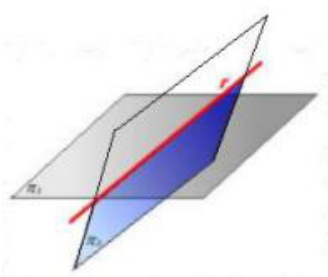

Figura 129. Representació de dos plans secants

2. Plans paral·lels no coincidents: no tenen cap punt en comú (figura 130). Analíticament $\pi_{1} \cap \pi_{2}=\Phi$.

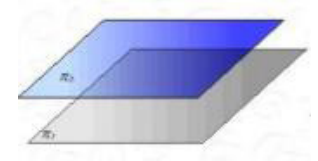

Figura 130. Representació de dos plans paral·lels no coincidents

3. Plans paral·lels coincidents: tenen tots els punts en comú (figura 131). Analíticament $\pi_{1} \cap \pi_{2}=\pi_{1}=\pi_{2}$.

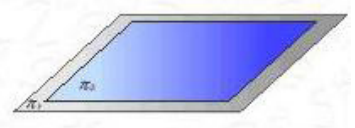

Figura 131. Representació de dos plans paral·lels coincidents

Quan dos plans són secants, determinen quatre regions en l'espai. S'anomena angle díedre o simplement díedre cadascuna d'aquestes regions, incloent-hi els semiplans que les delimiten (figura 132). La recta comuna als dos semiplans s'anomena aresta de l'angle díedre. Obtenim la mesura d'aquest angle si mesurem l'amplitud de l'angle pla que determinen dues semirectes d'origen comú contingudes en cadascun dels semiplans i que siguen perpendiculars a la seua recta d'intersecció.

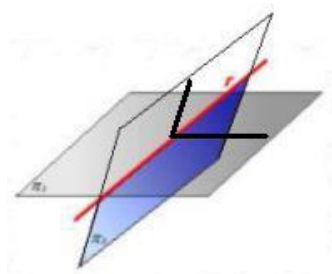

Figura 132. Representació dels elements d'un angle díedre 
Quan el nombre de plans que considerem en l'espai és superior a dos, la quantitat de posicions en les quals ens els podem trobar augmenta considerablement. Ens fixarem únicament en les situacions on tots els plans tenen sols un punt en comú i considerarem les semirectes d'origen comú en eixe punt, de manera que el pla determinat per cada dues semirectes consecutives deixa a totes les altres en el mateix semiespai. Anomenarem angle políedre convex la intersecció de tots els semiespais determinats pels plans que cada parella d'aquestes semirectes consecutives defineix (figura 133).

L'origen comú de les semirectes és el vèrtex de l'angle, cadascuna és una aresta de l'angle políedre i la porció de superfície plana limitada per cada dues semirectes consecutives (l'angle bidimensional que determinen) s'anomena cara de l'angle.

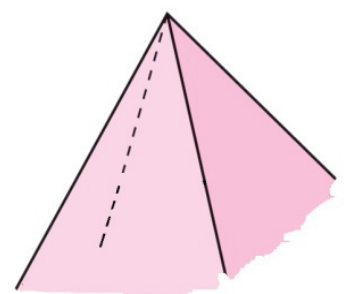

Figura 133. Representació d'un angle políedre

En el cas de tres plans amb un punt en comú, l'angle rep el nom d'angle tríedre o simplement tríedre. Quan el nombre de plans que determinen l'angle, $\boldsymbol{n}$, és igual o superior a quatre, aquest s'anomena bé amb les arrels gregues o bé amb l'expressió angle políedre amb $\boldsymbol{n}$ cares.

La mesura d'un angle políedre s'obté amb la suma de les amplituds de tots els angles bidimensionals que determinen les seues parelles d'arestes consecutives. L'amplitud de l'angle ha de ser menor que $360^{\circ}$, ja que si s'arribara a aquesta quantitat de graus, la superfície que formarien les cares de l'angle políedre seria un pla en l'espai i deixaria de limitar un angle políedre.

\subsubsection{Cossos geomètrics}

A més de les superfícies planes, en l'espai podem trobar superfícies que no ho són i que s'anomenen corbes. A diferència de les superfícies planes finites, que sempre són obertes, les superfícies finites corbes poden ser obertes o tancades (quan no envolten o sí que envolten una zona de l'espai, respectivament).

Un cos geomètric és una figura geomètrica que resulta de considerar una part de l'espai limitada per una superfície tancada simple (la que sols delimita una regió interior en l'espai) incloent aquesta superfície. Aquestes figures també s'anomenen sòlids. 
Anàlogament a les superfícies planes còncaves i convexes, es poden definir els cossos geomètrics còncaus i convexos.

Pel treball que es realitza a dintre de l'aula de primària, considerarem dos tipus de cossos geomètrics: els políedres i els cossos redons. Els primers estaran delimitats per polígons i els segons per superfícies corbes i/o superfícies planes no poligonals.

\subsubsection{Políedres}

Són els cossos geomètrics limitats per superfícies tancades simples compostes per polígons. A cadascun d'aquests polígons se l'anomena cara del políedre. Els costats dels polígons són les arestes del políedre i els seus vèrtexs són també vèrtexs del políedre. En cadascuna de les arestes es forma un angle díedre i en cadascun dels vèrtexs un angle políedre.

Qualsevol políedre convex té, almenys, quatre cares, quatre vèrtexs i sis arestes. Un vèrtex d'un políedre pertany, almenys, a tres cares i a tres arestes. En qualsevol políedre convex es compleix la fórmula d'Euler, que relaciona el nombre de cares $(C)$, de vèrtexs $(V)$ i d'arestes $(A)$, segons l'expressió: $C+V=A+2$.

Podem classificar els políedres en funció de les següents característiques: la regularitat de les cares, la igualtat d'aquestes i la igualtat dels angles del mateix tipus que es formen en el políedre. Obtindrem, així, dues classes, la dels políedres regulars i la dels que no ho són. Si un políedre verifica les tres condicions anteriors direm que és regular o platònic. Si no verifica alguna de les condicions anteriors, direm que és irregular. En particular, si verifica la primera i la tercera però no la segona, direm que és arquimedià.

\section{PolíEDRES REGULARS}

Estudiarem quins són els políedres regulars que hi ha i com es construeixen a partir dels polígons que els delimiten.

Tenint en compte que la mesura d'un angle políedre ha de ser menor que $360^{\circ}$ i que, com a mínim, en cada vèrtex han de concórrer tres cares, ens apareixen els següents sòlids platònics: 


\begin{tabular}{|c|c|c|c|c|}
\hline CARES & $\begin{array}{c}\text { Nombre } \\
\text { de cares } \\
\text { per vèrtex }\end{array}$ & $\begin{array}{l}\text { Suma dels } \\
\text { angles }\end{array}$ & Políedre & Representació \\
\hline \multirow{4}{*}{$\begin{array}{l}\text { Triangles } \\
\text { equilàters }\end{array}$} & 3 & $3 \cdot 60^{\circ}=180^{\circ}$ & $\begin{array}{c}\text { TETRÀEDRE } \\
\text { REGULAR }\end{array}$ & \\
\hline & 4 & $4 \cdot 60^{\circ}=240^{\circ}$ & $\begin{array}{l}\text { OCTÀEDRE } \\
\text { REGULAR }\end{array}$ & \\
\hline & 5 & $5 \cdot 60^{\circ}=300^{\circ}$ & $\begin{array}{c}\text { ICOSÀEDRE } \\
\text { REGULAR }\end{array}$ & \\
\hline & 6 & $6 \cdot 60^{\circ}=360^{\circ}$ & No existeix & \\
\hline \multirow[t]{2}{*}{ Quadrats } & 3 & $3 \cdot 90^{\circ}=270^{\circ}$ & $\begin{array}{c}\text { CUB O } \\
\text { HEXÀEDRE- } \\
\text { REGULAR }\end{array}$ & \\
\hline & 4 & $4 \cdot 90^{\circ}=360^{\circ}$ & No existeix & \\
\hline \multirow{2}{*}{$\begin{array}{l}\text { Pentàgons } \\
\text { regulars }\end{array}$} & 3 & $3 \cdot 108^{\circ}=324^{\circ}$ & $\begin{array}{c}\text { DODECÀEDRE } \\
\text { REGULAR }\end{array}$ & \\
\hline & 4 & $4 \cdot 108^{\circ}=432^{\circ}$ & No existeix & \\
\hline $\begin{array}{l}\text { Hexàgons } \\
\text { regulars }\end{array}$ & 3 & $3 \cdot 120^{\circ}=360^{\circ}$ & No existeix & \\
\hline
\end{tabular}

I com es veu, a partir de l'hexàgon regular, no es pot formar cap angle políedre perquè la suma de tres angles de qualsevol altre polígon regular sempre serà superior a $360^{\circ} \mathrm{i}$, per tant, no es podrà determinar cap políedre. Aleshores, només es poden formar políedres regulars amb triangles equilàters, quadrats i pentàgons regulars.

Cal fixar-se un poc en la construcció d'aquests cossos:

\section{Quan són triangles equilàters:}

A partir de la xarxa de triangles equilàters que ja s'ha estudiat (vegeu 3.2.3.1 d'aquest tema), ens fixem només en una part, la que forma un hexàgon (figura 134).
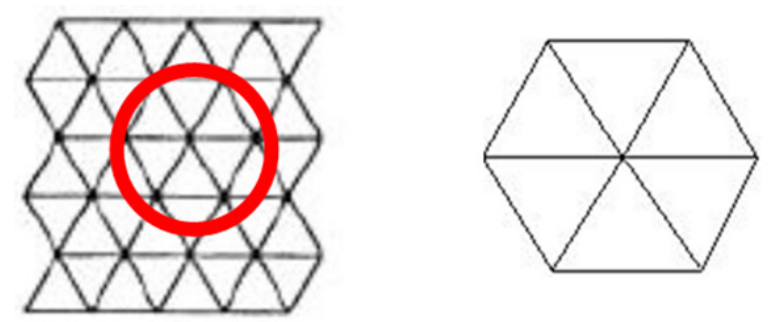

Figura 134. Representació d'una xarxa de triangles equilàters (esquerra) i una selecció de sis (dreta) 
És clar que aquest hexàgon no es pot doblegar per a formar una figura susceptible de ser un cos geomètric (com es pot veure en el quadre anterior). Caldrà, doncs, llevar triangles per a poder fer- ho.

Si es lleva un dels triangles, aleshores el cos que es pot formar tindrà vèrtexs en els quals conflueixen cinc cares que són triangles equilàters. Perquè el cos acomplisca totes les condicions per a ser regular, necessitem quinze triangles equilàters més, $\mathrm{i}$ el que se n'obté rep el nom d'icosàedre regular (figura 135).

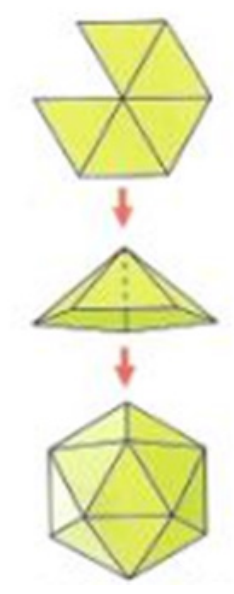

Figura 135. Representació de la construcció d'un icosàedre regular

Si es lleven ara dos triangles equilàters, el cos que es pot formar tindrà vèrtexs en els quals conflueixen quatre triangles equilàters. Per a completar el cos regular en aquest cas, necessitem quatre triangles equilàters més i el que s'obté és un octàedre regular (figura 136).

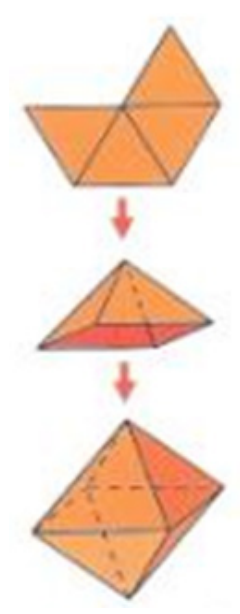

Figura 136. Representació de la construcció d'un octàedre regular

Per últim, si són tres els triangles que es lleven, el cos que es pot formar tindrà vèrtexs en els quals confluiran tres triangles equilàters. Sols necessitarem un altre per a completar el cos geomètric anomenat tetràedre regular (figura 137). 


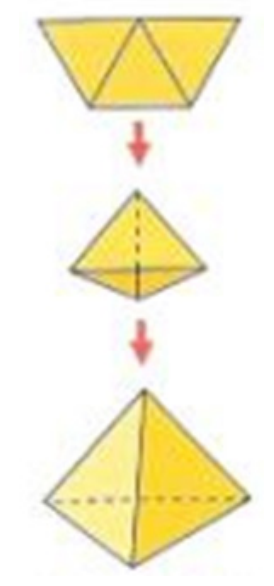

Figura 137. Representació de la construcció d'un tetràedre regular

Nota: En general, qualsevol políedre les cares del qual siguen totes triangles equilàters, s'anomena deltàedre.

\section{Quan són quadrats:}

A partir de la xarxa formada per quadrats (figura 138) i agafant-ne només quatre, es pot seguir un procediment semblant.

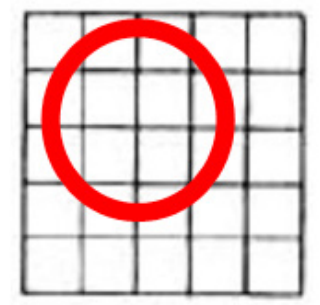

Figura 138. Representació d'una xarxa de quadrats

Com que necessitem tres cares per a aconseguir un vèrtex, només es pot llevar un dels quadrats. Faran falta tres quadrats més per a completar el cos geomètric que es denomina hexàedre regular o cub (figura 139).

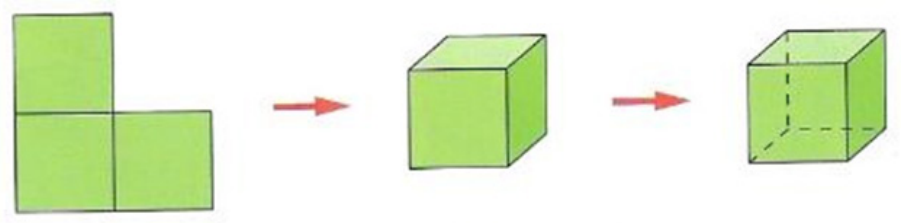

Figura 139. Representació de la construcció d'un cub

\section{Quan són pentàgons regulars:}

En aquest cas no es pot partir d'una xarxa plana, no existeix, ja que amb pentàgons regulars no es pot recobrir el pla, però sí que es pot formar un políedre. Quan es 
construeix el vèrtex fent coincidir tres cares en aquest, la suma dels angles que el formen és menor que $360^{\circ}$, ja que cadascun dels angles interiors d'un pentàgon regular mesura $108^{\circ}$.

En aquest cas necessitarem nou pentàgons més per a completar el cos que s'anomena dodecàedre regular (figura 140).

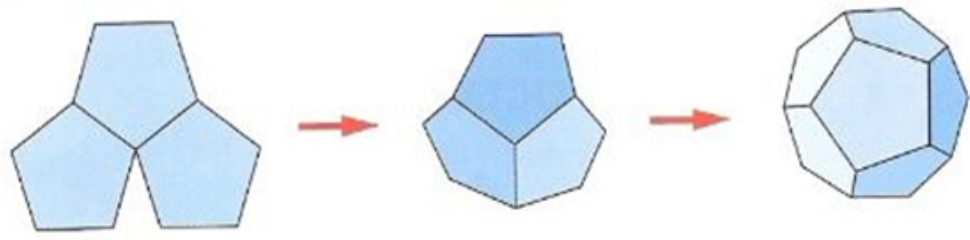

Figura 140. Representació de la construcció d'un dodecàedre regular

Dins del conjunt dels políedres, trobem unes famílies molt particulars, la dels prismes i la de les piràmides que, per la gran varietat de cossos que contenen i per la seua presència en la realitat, seran les primeres que estudiarem.

\section{PRISMES}

Un prisma és un políedre limitat per dos polígons iguals i paral·lels que s'uneixen mitjançant tants paral·lelograms com costats tinguen aquells (figura 141). Els polígons esmentats reben el nom de bases o cares bàsiques (homòlegs en una translació, vegeu 3.4.1.1 d'aquest tema) i els paral·lelograms, cares laterals. L'altura del prisma és el segment de la perpendicular a les dues bases comprès entre elles.

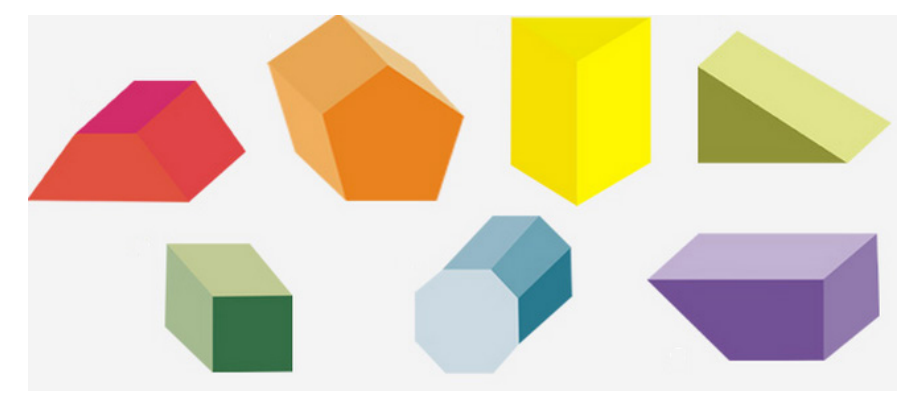

Figura 141. Representació de prismes de diferents bases

Si les bases del prisma són polígons còncaus o convexos el prisma serà còncau $\mathrm{o}$ convex, respectivament.

Si totes les cares laterals són rectangles, seran perpendiculars a les bases, i és per això que s'anomena prisma recte. Si les cares laterals no són perpendiculars a les bases, es denomina prisma oblic (figura 142). 


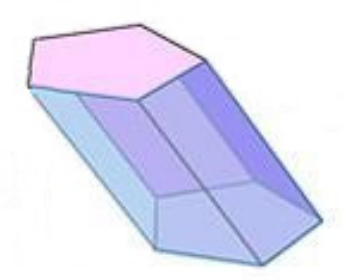

Figura 142. Representació d'un prisma oblic

Si les bases d'un prisma recte són polígons regulars, el prisma és regular.

Les arestes laterals d'un prisma són segments iguals i paral·lels entre si. En els prismes rectes són perpendiculars a les bases.

Segons que les bases siguen triangles, quadrilàters, pentàgons, etc., el prisma es denomina triangular, quadrangular, pentagonal, etc.

El desenvolupament pla d'un prisma és el resultat de desplegar i col·locar a sobre d'un pla totes les seues cares de manera que cada dues contigües estiguen unides per una aresta. Vegem, per exemple, en la figura 143, el cas d'un prisma regular hexagonal.

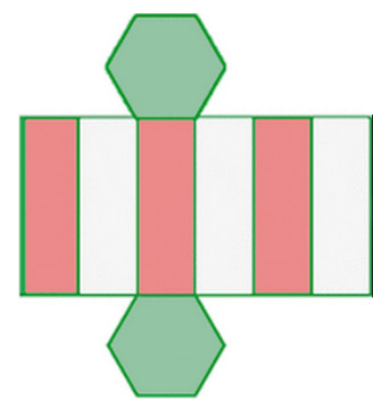

Figura 143. Representació del desenvolupament pla d'un prisma regular hexagonal (imatge proporcionada per narceaeduplastica.weebly.com)

És important destacar que l'expressió «desenvolupament pla d'un cos geomètric» es refereix sols al de la superfície que limita el cos i no al del cos complet que és sòlid i massís i que, evidentment, no es pot desenvolupar en un pla.

\section{Paral·lelepípedes:}

Un paral·lelepípede és un prisma les cares del qual són totes paral·lelograms. Cada dues cares oposades són iguals (figura 144).

Si les bases són quadrats, aquest paral·lelepípede serà un prisma quadrangular, ja esmentat abans.

Si totes les cares són rectangles, es denomina ortòedre. Si són quadrats, s'anomena hexàedre regular o cub, també esmentat abans. Si són rombes, serà rombòedre. 


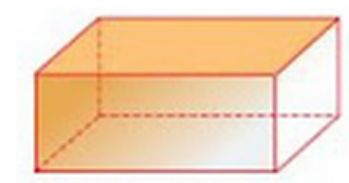

Figura 144. Representació d'un ortòedre

\section{PIRÀMIDES}

Una piràmide és un políedre limitat per un polígon qualsevol, la seua base, unit a tants triangles com costats hi té, les seues cares laterals, que coincideixen en un vèrtex, cúspide o àpex de la piràmide, en què tots els triangles formen un angle políedre. L'altura és el segment de la perpendicular a la base traçada pel vèrtex de la piràmide, que té per extrems el propi vèrtex i la intersecció d'aquesta perpendicular amb el pla que conté la base de la piràmide.

Si la base de la piràmide és un polígon còncau o convex la piràmide s'anomena còncava o convexa, respectivament.

Si les cares laterals són triangles isòsceles (poden ser també equilàters), la piràmide es denomina recta. En cas contrari, serà obliqua (figura 145).
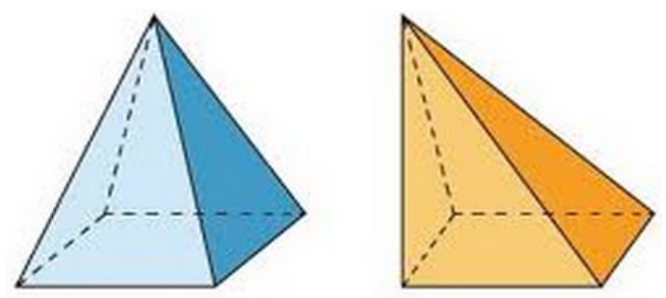

Figura 145. Representació d'una piràmide quadrangular recta (esquerra) i d'una obliqua (dreta)

Si la base d'una piràmide recta és un polígon regular, aquesta serà una piràmide regular. El vèrtex de la piràmide regular es projecta sobre el centre de la seua base.

En una piràmide regular totes les arestes laterals són de la mateixa longitud i les cares laterals són triangles isòsceles iguals. Les altures dels triangles són les apotemes de la piràmide.

Segons que les bases siguen triangles, quadrilàters, pentàgons, etc., la piràmide s'anomenarà triangular, quadrangular, pentagonal...

Vegem en la figura 146 un exemple del desenvolupament pla d'una piràmide regular quadrangular. 


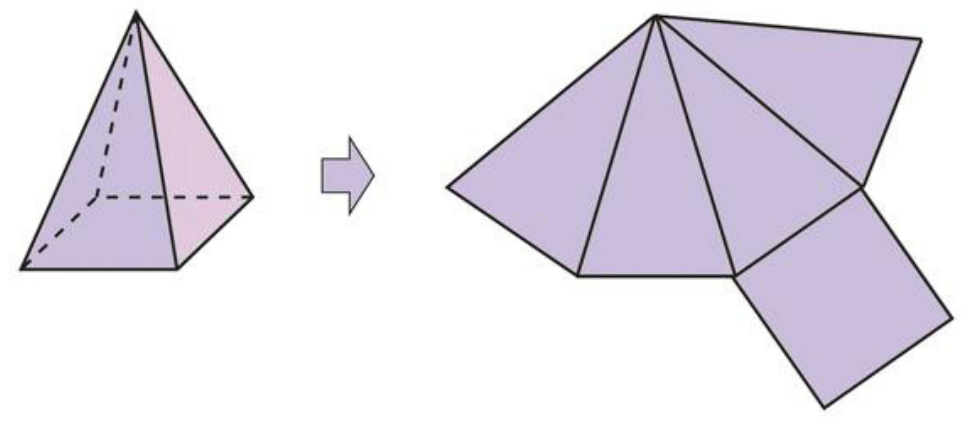

Figura 146. Representació del desenvolupament pla d'una piràmide regular quadrangular

\section{Tronc de piràmide}

Quan es talla una piràmide per un pla paral·lel al de la base, el cos comprés entre els dos plans es denomina tronc de piràmide (figura 147).

Un tronc de piràmide té dues bases que són polígons semblants (homòlegs en una semblança, vegeu 3.3.2.4 d'aquest tema). L'altura del tronc és el segment de la perpendicular als plans que contenen les dues bases, comprés entre aquests.

Si la piràmide és regular, el tronc de piràmide corresponent també s'anomena regular. Les cares laterals són trapezis isòsceles iguals. L'altura de cadascun d'ells es denomina apotema del tronc de piràmide.

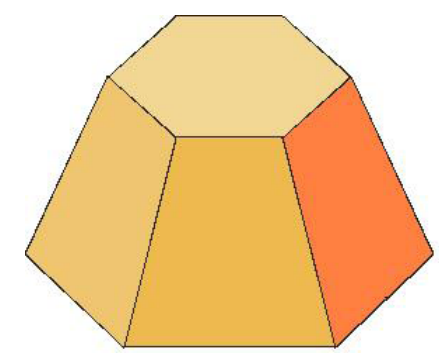

Figura 147. Representació d'un tronc de piràmide regular hexagonal

\subsubsection{Cossos redons}

Seran aquells cossos geomètrics limitats per superfícies tancades simples on totes les cares siguen superfícies corbes i/o planes no poligonals.

Encara que hi ha molts cossos d'aquest tipus, ens interessarem particularment per aquells que deriven del cercle o que contenen cercles entre les superfícies que els delimiten.

Començarem parlant dels cossos de revolució que són els sòlids que en resulten quan fem girar una figura plana al voltant d'un eix, anomenat eix de revolució. 
En funció de com siga aquesta figura, obtindrem diferents cossos. Estudiarem a continuació els més representatius per a l'aula de primària: el cilindre, el con i l'esfera.

\section{Cilindre}

Si es fa girar una recta, anomenada generatriu, al voltant d'un eix paral lel a ella, es genera una superfície infinita, en forma de tub, que denominem superfície cilíndrica circular recta. El cos que queda delimitat en tallar una d'aquestes superfícies per dos plans paral·lels entre si i perpendiculars a l'eix de revolució, s'anomena cilindre circular recte. La intersecció d'aquests plans amb la superfície cilíndrica dóna lloc a dues circumferències que determinen dos cercles. Aquests dos cercles són les bases del cilindre i la superfície cilíndrica compresa entre aquestes és la superfície o cara lateral del cilindre.

De manera més intuïtiva podem definir el cilindre circular recte, d'ara endavant cilindre recte, com el cos geomètric que s'obté en fer girar un rectangle al voltant d'un dels seus costats. Els cercles que generen els dos costats perpendiculars al que actua com a eix de revolució, són les bases del cilindre.

L'altura, $\boldsymbol{h}$, és el segment de la perpendicular als plans que contenen les bases comprés entre aquests $i$ el radi de les bases és el radi del cilindre, $\boldsymbol{r}$.

De manera anàloga als políedres, podem obtenir el desenvolupament pla d'un cos redó. En la figura 148 es mostra un cilindre recte i el seu desenvolupament pla.

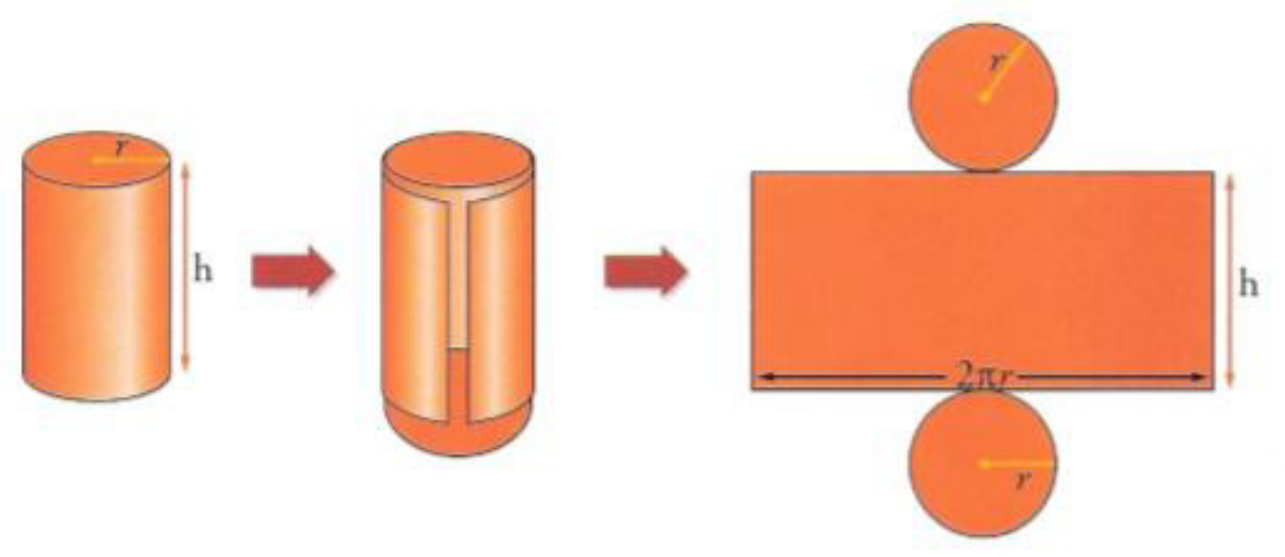

Figura 148. Representació d'un cilindre circular recte i el seu desenvolupament pla

Quan la generatriu del cilindre circular no és perpendicular a les bases, el cilindre s'anomena oblic, com es mostra en la figura 149. 


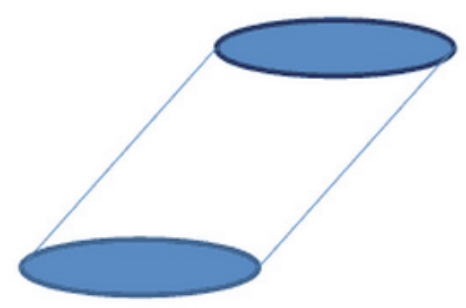

Figura 149. Representació d'un cilindre oblic

Es pot estendre la idea de cilindre, tant recte com oblic, a uns altres cossos redons les bases del quals no són cercles, sinó superfícies planes que poden estar delimitades per el·lipsis o altres tipus de línies corbes tancades planes (figura 150).

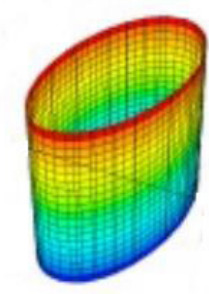

Figura 150. Representació d'un cilindre el·líptic

La superfície cilíndrica també es pot entendre com la superfície generada per una recta que es desplaça paral·lela a si mateixa i tangent a una línia corba tancada que rep el nom directriu.

\section{CON}

Si fem girar una recta anomenada generatriu al voltant d'un eix, al qual talla, es genera un superfície infinita, en forma de dos cucurutxos amb el vèrtex comú, que denominem superfície cònica. El cos que queda delimitat en tallar la superfície cònica anterior pel vèrtex i per un pla perpendicular a l'eix de revolució s'anomena con circular recte. La intersecció d'aquest pla amb la superfície cònica dóna lloc a una circumferència que determina un cercle. Aquest cercle és la base del con i la superfície cònica compresa entre aquesta i el vèrtex es la superfície o cara lateral del con.

Anàlogament al cas del cilindre, podem definir el con circular recte, o simplement con recte, com el cos geomètric que s'obté en fer girar un triangle rectangle al voltant d'un dels seus catets. El cercle que genera quan gira l'altre catet del triangle és la base del con.

El segment de la generatriu comprés entre el vèrtex i la base, és la generatriu del con, $\boldsymbol{g}$. L'altura, $\boldsymbol{h}$, és el segment de la perpendicular al pla que conté la base del con traçada pel vèrtex i comprés entre aquest i l'esmentat pla. El radi de la base és el radi del con, $\boldsymbol{r}$. En el cas dels cons rectes, l'altura uneix el vèrtex amb el centre del cercle de la base. 
De manera semblant al cilindre, podem obtenir el desenvolupament pla d'un con, com es mostra en la figura 151.

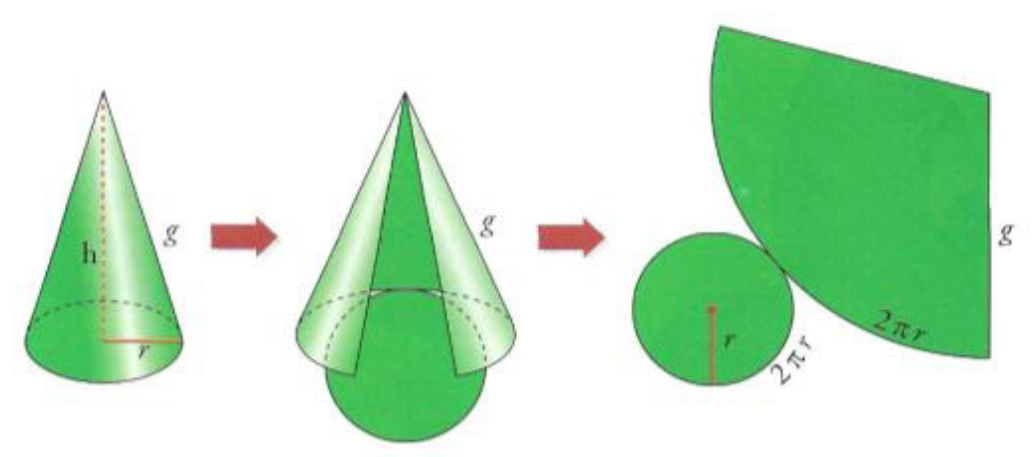

Figura 151. Representació d'un con circular recte i el seu desenvolupament pla

Quan el pla que conté la base del con circular no és perpendicular a l'eix de revolució, el con s'anomena oblic (figura 152). En aquest cas, l'altura del con no passa pel centre de la base.

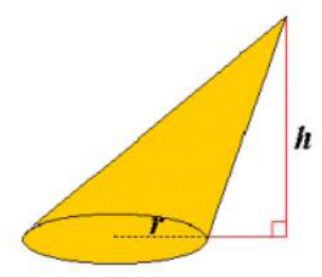

Figura 152. Representació d'un con oblic

Es pot estendre la idea de con, tant recte com oblic, a uns altres cossos redons la base del quals no és un cercle, sinó una superfície plana que pot estar delimitada per el·lipsis o uns altres tipus de línies corbes tancades planes.

La superfície cònica també es pot entendre com la superfície generada per una recta que es desplaça mantenint fix un dels seus punts i de manera tangent a una línia corba tancada que s'anomena directriu.

\section{Tronc de con}

Si es talla un con per un pla paral·lel al que conté la base, el cos geomètric comprés entre els dos plans, es denomina tronc de con (figura 153).

El tronc de con recte és un cos de revolució que es genera fent girar un trapezi rectangle al voltant del costat perpendicular a les bases. Té dues cares bàsiques circulars i l'altura és el segment de la perpendicular als plans que contenen les bases comprés entre aquests. La generatriu, $\boldsymbol{g}$, és el segment que ha generat la superfície lateral i, per tant, és el costat del trapezi no perpendicular a les bases. 

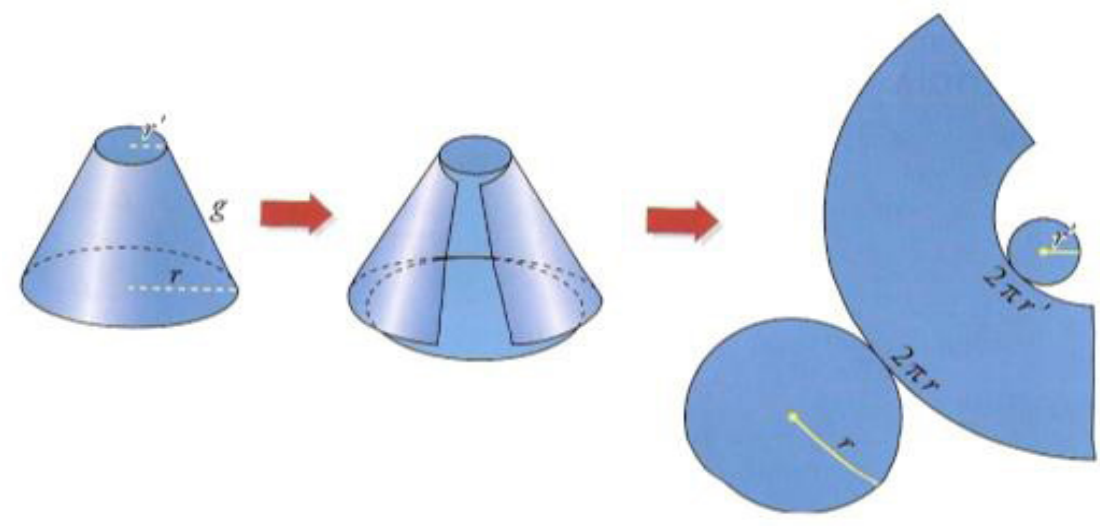

Figura 153. Representació d'un tronc de con recte i el seu desenvolupament pla

\section{ESFERA}

L'esfera es genera fent girar un semicercle al voltant d'un eix que conté el diàmetre que el determina. També es pot definir com el lloc geomètric dels punts de l'espai la distància dels quals a un punt anomenat centre és menor o igual que un valor $\boldsymbol{R}$ anomenat radi.

La superfície de l'esfera, anomenada superfície esfèrica, es genera en fer girar una semicircumferència al voltant del diàmetre. Només es pot desenvolupar sobre el pla aproximadament, però no de manera exacta.

A continuació es defineixen algunes figures derivades de l'esfera i la superfície esfèrica.

Denominem casquet esfèric (figura 154) cadascuna de les dues parts de la superfície esfèrica que resulten de tallar-la amb un pla. Si el que es talla és una esfera, les dues parts resultants s'anomenen segments esfèrics d'una base. Si el pla secant passa pel centre, obtindrem, respectivament, dues semisuperfícies esfèriques o dues semiesferes.

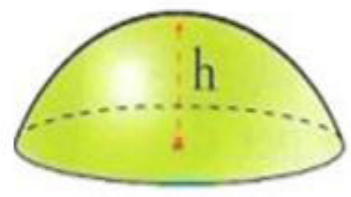

Figura 154. Representació d'un casquet esfèric

La porció de superfície esfèrica compresa entre dos plans paral·lels que la tallen, s'anomena zona esfèrica (figura 155). Si el que es talla és una esfera, la figura resultant es diu segment esfèric de dues bases. 


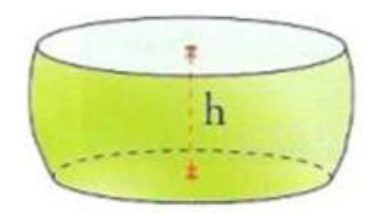

Figura 155. Representació d'una zona esfèrica

Si es considera un angle díedre, l'aresta del qual conté el diàmetre de l'esfera, la seua intersecció amb la superfície esfèrica es denomina fus esfèric. La intersecció amb l'esfera s'anomena tascó esfèric, falca esfèrica o cuny esfèric (figura 156).

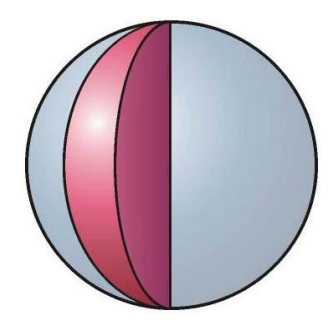

Figura 156. Representació d'un tascó esfèric

\subsection{Transformacions geomètriques en el pla}

Com ja s'ha explicat en el punt 2.2 d'aquest tema, una transformació geomètrica és una aplicació bijectiva de l'espai en si mateix que pren una figura geomètrica i la transforma en una altra. En aquest apartat treballarem algunes de les transformacions geomètriques planes que es poden definir. Concretament, veurem les isometries i les transformacions equiformes en el pla.

\subsubsection{Moviments rígids o isometries}

Un moviment rígid o isometria és una transformació geomètrica que conserva les dimensions de les figures. Dit d'una altra manera, és una transformació que compleix la següent condició: la distància entre els punts de la figura original és la mateixa que la que hi ha entre els seus corresponents homòlegs en la figura transformada. Quan dues figures són homòlogues per una isometria es diu que són congruents.

\subsubsection{Translacions}

Una translació de vector $\vec{v}, T_{\vec{v}}$ és un moviment rígid en el pla en el qual tots els seus punts es desplacen seguint aquest vector que s'anomena vector de translació. Per veure el comportament d'aquestes transformacions, treballem amb l'exemple de la figura 157 , on la translació està determinada pel vector lliure $\vec{v}=\overrightarrow{A A^{\prime}}$. 


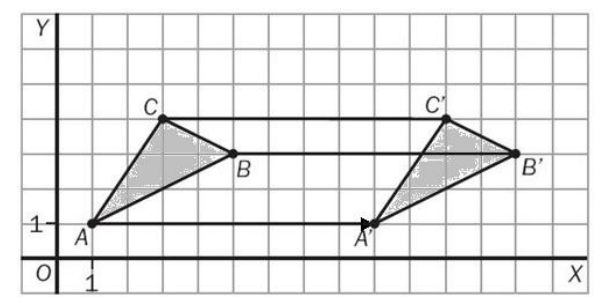

Figura 157. Representació de dos triangles homòlegs per una translació

En aquest cas $T_{\vec{v}}(A)=A^{\prime}$ i la figura homòloga del triangle $\boldsymbol{A} \boldsymbol{B C}$ és el triangle $\boldsymbol{A}^{\prime} \boldsymbol{B} \boldsymbol{B}^{\prime} \boldsymbol{C}^{\prime}$. Es pot comprovar que les distàncies entre dos punts i els seus corresponents transformats son iguals $\left(\boldsymbol{d}(\boldsymbol{A}, \boldsymbol{C})=\boldsymbol{d}\left(\boldsymbol{A}^{\prime}, \boldsymbol{C}^{\prime}\right)\right.$, per exemple) o el que és el mateix, es conserven les distàncies, per tant, és una isometria.

Com es veu en la figura 157, el sentit d'orientació del pla que determinen els punts $\boldsymbol{A}, \boldsymbol{B}$ i $\boldsymbol{C}$, és el mateix que el determinat pels respectius homòlegs d'aquests $\boldsymbol{A}^{\prime}, \boldsymbol{B}^{\prime}$ i $C^{\prime}$, és a dir, la translació és una isometria que conserva el sentit d'orientació del pla. Per aquesta raó, les translacions s'anomenen moviments directes.

Quan el vector $\vec{v}=\mathbf{0}$, la translació és la transformació identitat, i aleshores per qualsevol punt $\boldsymbol{P}$ del pla: $T_{o}(P)=P$.

\subsubsection{Girs o rotacions}

Un gir o rotació de centre $\boldsymbol{O}$ i angle $\alpha, G_{O, \alpha}$, és un moviment rígid en el pla segons el qual un punt qualsevol d'aquest $\boldsymbol{P}$ distint de $\boldsymbol{O}$, es transforma en un altre punt $\boldsymbol{P}$ ', de manera que $\mathrm{PO}^{\prime} \mathrm{P}^{\prime}=\alpha, \boldsymbol{d}(\boldsymbol{O}, \boldsymbol{P})=\boldsymbol{d}\left(\boldsymbol{O}, \boldsymbol{P}^{\prime}\right)$ i el centre de gir $\boldsymbol{O}$ és un punt fix que es transforma en ell mateix: $G_{O, \alpha}(O)=O$.

L'angle de gir ve determinat per l'amplitud d'aquest i un sentit de gir. Aquest sentit serà negatiu quan coincidisca amb el moviment de les agulles del rellotge i positiu en cas contrari.

Per veure un exemple de gir, treballem amb la figura 158, on el centre de gir és l'origen de coordenades i l'angle de gir és $\alpha=+\mathbf{9 0}^{\circ}$.

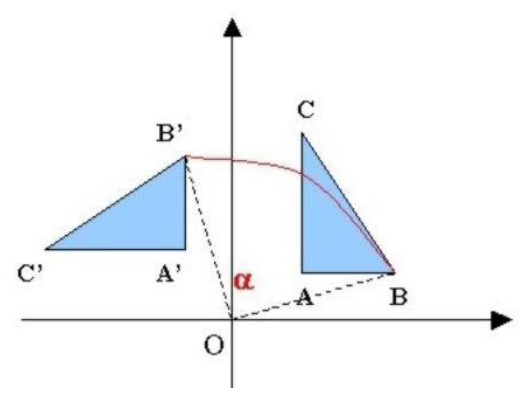

Figura 158. Representació de dos triangles homòlegs per un gir 
En aquest cas $G_{O,+90^{\circ}}(B)=B^{\prime}$ i la figura homòloga del triangle $A B C$ és el triangle $A^{\prime} \boldsymbol{B}$ ' $C^{\prime}$. Es pot comprovar també que les distàncies entre dos punts i els seus corresponents transformats son iguals $\left(\boldsymbol{d}(\boldsymbol{A}, \boldsymbol{C})=\boldsymbol{d}\left(\boldsymbol{A}^{\prime}, \boldsymbol{C}^{\prime}\right)\right.$, per exemple) o el que és el mateix, es conserven les distàncies, per tant, és una isometria.

Com es veu en la figura 158, el sentit d'orientació del pla que determinen el punts $\boldsymbol{A}, \boldsymbol{B}$ i $\boldsymbol{C}$ és el mateix que el determinat pels respectius homòlegs d'aquests $\boldsymbol{A}^{\prime}, \boldsymbol{B}{ }^{\prime} \mathrm{i}$ $C^{\prime}$, és a dir, el gir és una isometria que conserva el sentit d'orientació del pla. Per aquesta raó, els girs s'anomenen també moviments directes.

Quan l'angle és $\mathbf{0}^{\circ}$ el gir és la transformació identitat i per a qualsevol punt $\boldsymbol{P}$ del pla: $G_{O, 0^{\circ}}(P)=P$.

I quan l'angle és $\mathbf{1 8 0}^{\circ}$, el gir s'anomena simetria central: $G_{O, 180^{\circ}}=S_{O}$. Un exemple d'aquestes transformacions es veu en la figura 159 , on $\mathbf{O}$ és el punt $(0,+1)$.

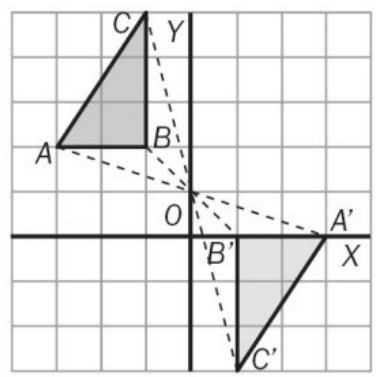

Figura 159. Representació de dos triangles homòlegs per una simetria central (gir de $180^{\circ}$ )

\subsubsection{Simetries axials}

Una simetria axial d'eix $\boldsymbol{e}, S_{e}$, és un moviment rígid en el pla en el qual un punt d'aquest $\boldsymbol{P}$, exterior a la recta $\boldsymbol{e}$, es transforma en un altre punt $\boldsymbol{P}$ ' de manera que la recta $\boldsymbol{e}$ és la mediatriu del segment $\overline{P P^{\prime}}$ i qualsevol punt $\boldsymbol{Q}$ de l'eix de simetria es transforma en ell mateix, $S_{e}(Q)=Q$, és a dir, l'eix de simetria és homòleg de sí mateix, $S_{e}(e)=e$.

Per a veure un exemple de simetria axial, treballem amb la figura 160, on l'eix de simetria és la recta vertical $\boldsymbol{e}$.

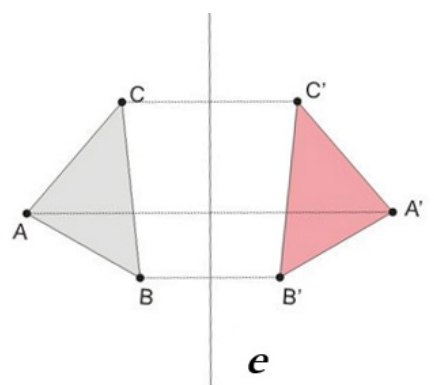

Figura 160. Representació de dos triangles homòlegs per una simetria axial 
En aquest cas $S_{e}(A)=A^{\prime}$ i la figura homòloga del triangle $\boldsymbol{A B C}$ és el triangle $\boldsymbol{A}^{\prime} \boldsymbol{B}$ ' $\boldsymbol{C}$ '. Anàlogament a les transformacions anteriors, es pot comprovar que les distàncies entre dos punts i els seus corresponents transformats són iguals $(\boldsymbol{d}(\boldsymbol{A}, \boldsymbol{C})$ $=\boldsymbol{d}\left(\boldsymbol{A}^{\prime}, C^{\prime}\right)$, per exemple) o el que és el mateix, es conserven les distàncies, per tant, és una isometria.

Com es veu en la figura 160, el sentit d'orientació del pla que determinen el punts $\boldsymbol{A}, \boldsymbol{B}$ i $\boldsymbol{C}$, és invers al determinat pels seus respectius homòlegs $\boldsymbol{A}^{\prime}, \boldsymbol{B}^{\prime}$ i $\boldsymbol{C}^{\prime}$. La simetria axial és, per tant, un moviment que canvia el sentit d'orientació del pla. Per aquesta raó les simetries axials s'anomenen moviments inversos.

\subsubsection{Composició de moviments en el pla}

Si apliquem successivament dos moviments a una figura geomètrica plana obtenim com a resultat una figura congruent amb la primera. Direm que aquestes dues figures són homòlogues mitjançant una composició de moviments. Intuïtivament el que s'hi fa és desplaçar i girar la figura original, o desplaçar-la dues vegades, o girar-la i després desplaçar-la...

Quan componem dues simetries axials obtenim com a resultat translacions o girs segons els eixos de les simetries siguen, respectivament, paral·lels o secants. Podem observar aquestes composicions en la figura 161.

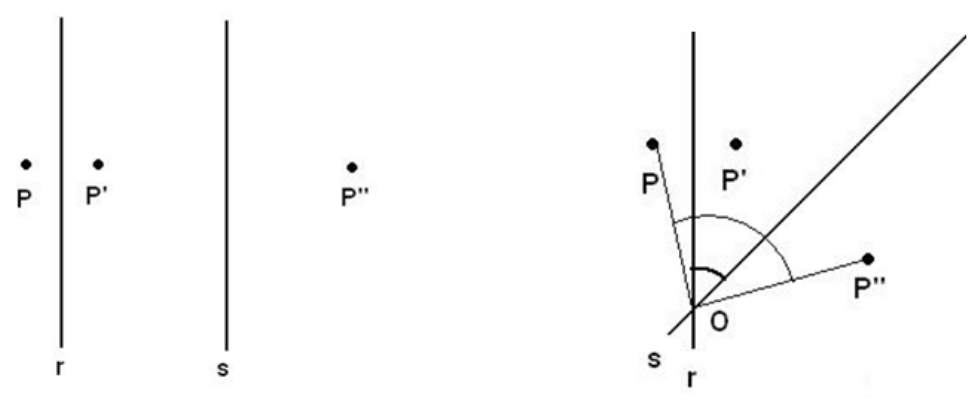

Figura 161. Representació de dos composicions de simetries axials: eixos paral·lels (esquerra) i eixos secants (dreta)

En el cas dels eixos paral'lels el punt $\boldsymbol{P}$ s'ha traslladat a $\boldsymbol{P}$ ', d'acord amb el vector de translació $\overrightarrow{P P}^{\prime \prime}$, de direcció perpendicular als eixos de les simetries el sentit del qual té origen $\boldsymbol{P}$ i extrem $\boldsymbol{P}$ "' i de mòdul $\left|\overrightarrow{P P^{\prime \prime}}\right|=2 \cdot d(r, s)$.

Si els eixos es tallen en el punt $\mathbf{O}$ i formen un angle agut $\alpha$, el punt $\boldsymbol{P}$ s'ha transformat en $\boldsymbol{P}$ ', segons un gir de centre $\mathbf{O}$ i d'angle $P O^{\prime \prime}=2 \cdot \alpha$. 


\subsubsection{Transformacions equiformes}

Una transformació geomètrica equiforme és la que transforma una figura en una altra de la mateixa forma i dimensions proporcionals a les de l'original. Quan dues figures són homòlogues per una transformació equiforme es diu que són semblants.

\subsubsection{Proporcionalitat de segments}

Donats dos segments $\overline{A B}$ i $\overline{C D}$, definim raó entre aquests com la raó numèrica entre les seues respectives longituds, calculades respecte d'una unitat de mesura comuna. És a dir, $\frac{\overline{A B}}{\overline{C D}}=\frac{d(A, B)}{d(C, D)}$.

Si tenim dos parells de segments $\overline{A B}$ i $\overline{C D}, \overline{P Q}$ i $\overline{R S}$, direm que són proporcionals si les raons entre els segments de cada parell són iguals, és a dir: $\frac{\overline{A B}}{\overline{C D}}=\frac{\overline{P Q}}{\overline{R S}}$. A aquest valor se l'anomena raó de proporcionalitat entre els parells de segments.

\subsubsection{Teorema de tales}

Una aplicació directa de la definició de proporcionalitat entre segments que acabem de veure és el conegut teorema de Tales: «Si tres rectes paral·leles a, b i c tallen dues rectes secants $\mathbf{r}$ i r', els segments que es determinen en elles són proporcionals». Una representació geomètrica d'aquest teorema s'ofereix en la figura 162.

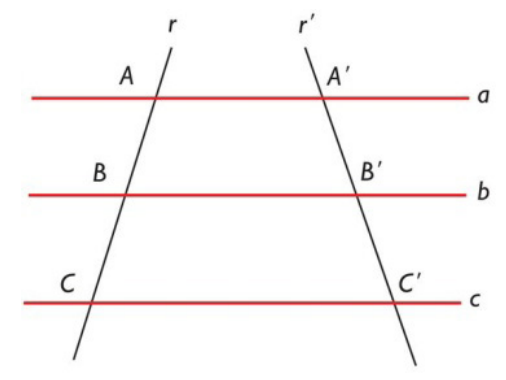

Figura 162. Representació geomètrica del teorema de Tales

De la representació anterior, es desprén la següent relació entre les mesures dels segments:

$$
\frac{\overline{A B}}{\overline{A^{\prime} B^{\prime}}}=\frac{\overline{B C}}{\overline{B^{\prime} C^{\prime}}}=\frac{\overline{A C}}{\overline{A^{\prime} C^{\prime}}}
$$

Aquest teorema és molt important per a treballar la semblança de figures en general i en particular la de triangles. 


\subsubsection{Homotècies}

Una homotècia de centre $\boldsymbol{O}$ i raó $k \in R, \boldsymbol{H}_{\boldsymbol{o}, \boldsymbol{k}}$, és una transformació geomètrica en el pla en la qual un punt qualsevol d'aquest $\boldsymbol{P}$ distint de $\boldsymbol{O}$, es transforma en un altre punt $\boldsymbol{P}^{\prime}$, situat a sobre de la recta $\boldsymbol{O P}$ tal que $\overline{O P^{\prime}}=k \cdot \overline{O P}$ i el punt $\boldsymbol{O}$ roman fix. Com s'observa en la figura $163, \boldsymbol{H}_{\boldsymbol{O}, \boldsymbol{k}}(\boldsymbol{A})=\boldsymbol{A}^{\prime}$ ' i $\operatorname{com} \boldsymbol{k}>\boldsymbol{0}$ el punt $\boldsymbol{A}^{\prime}$ pertany a la semirecta $\boldsymbol{O} \boldsymbol{A}$. La figura homòloga del pentàgon $\mathrm{ABCDE}$ és el pentàgon A'B'C'D'E'.

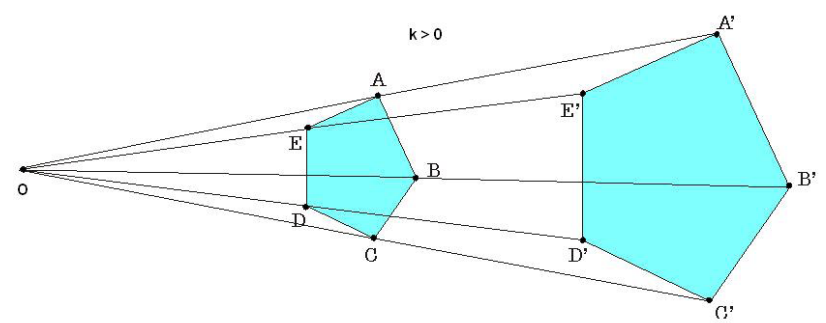

Figura 163. Representació de dos pentàgons homòlegs per una homotècia de raó positiva

Anàlogament, si $\boldsymbol{k}<\boldsymbol{0}$ el punt $\boldsymbol{A}$ ' pertany a la semirecta oposada a $\boldsymbol{O} \boldsymbol{A}$, com s'observa en la figura 164 .

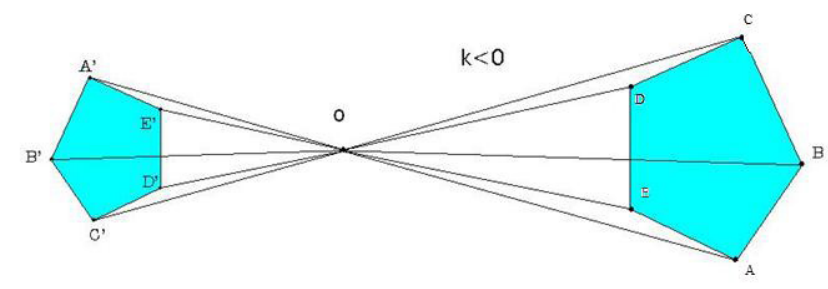

Figura 164. Representació de dos pentàgons homòlegs per una homotècia de raó negativa

Cal notar que si $|k|>1$ les longituds que es puguen mesurar en la figura homòloga són proporcionalment majors que les corresponents de la figura original, és a dir, la figura homòloga és una ampliació de la inicial.

Si $0<|k|<1$ les longituds de la figura homòloga són proporcionalment menors que les corresponents de la figura original, és a dir, la figura homòloga és una reducció de la inicial.

En les figures anteriors es pot veure una ampliació en el primer cas i una reducció en el segon. 


\subsubsection{Semblances}

Una semblança és una transformació geomètrica en el pla que resulta de la composició d'una homotècia i un moviment rígid o a l'inrevés.

Com ja s'ha esmentat, dues figures són semblants quan tenen la mateixa forma i les dimensions dels segments homòlegs són proporcionals (figura 165).

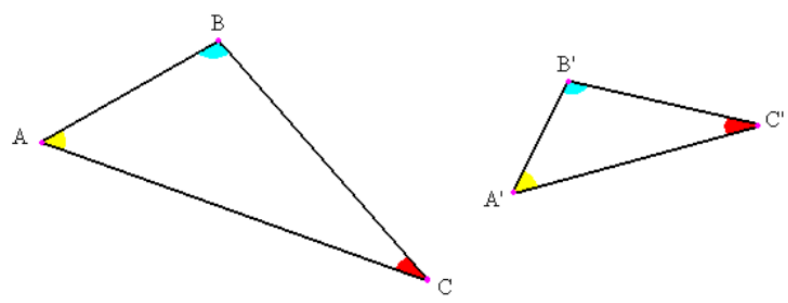

Figura 165. Representació de dos triangles semblants

D'aquesta definició es dedueix que qualsevol homotècia és una semblança on el moviment rígid utilitzat en la composició de transformacions és la identitat.

De la mateixa manera es pot deduir també que un moviment és una semblança l'homotècia de la qual és de raó +1 .

\subsection{Transformacions geomètriques en l'espai}

Totes les transformacions vistes en el pla tenen les seues corresponents en l'espai.

La definició de translació espacial és idèntica a la que s'ha donat per al cas del pla, tenint en compte que les figures són tridimensionals i els vectors han de situar-se en l'espai.

La definició de gir en l'espai es anàloga a la de gir en el pla, amb la diferència que, en l'espai, es gira al voltant d'un eix que es manté fix, en lloc de girar al voltant d'un punt.

Una simetria axial en l'espai és un gir espacial l'eix del qual és el de la simetria i l'amplitud de l'angle de gir és de $180^{\circ}$.

La definició d'homotècia espacial és anàloga a la que s'ha donat en el cas del pla, tenint en compte que les figures són tridimensionals.

La definició de semblança espacial és idèntica a la que s'ha donat per al cas del pla, tenint en compte que les figures són tridimensionals.

Com que la simetria especular en l'espai és una transformació que no procedeix de la generalització en l'espai de cap transformació plana, és la que es tractarà de manera més detallada. 


\subsubsection{Simetria especular}

Una simetria especular respecte del pla $\pi, S_{\pi}$ és una transformació geomètrica en l'espai segons la qual un dels seus punts, $\boldsymbol{A}$, exterior al pla $\pi$, es transforma en un altre punt $A^{\prime}$ ' de manera que $\pi$ és el pla «mediatriu» del segment $\overline{A A^{\prime}}$ i qualsevol punt $Q$ del pla de simetria es transforma en ell mateix, $S_{\pi}(Q)=Q$, és a dir, el pla de simetria és homòleg de si mateix, $S_{\pi}(\pi)=\pi$. Un exemple de simetria especular el trobem en la figura 166.

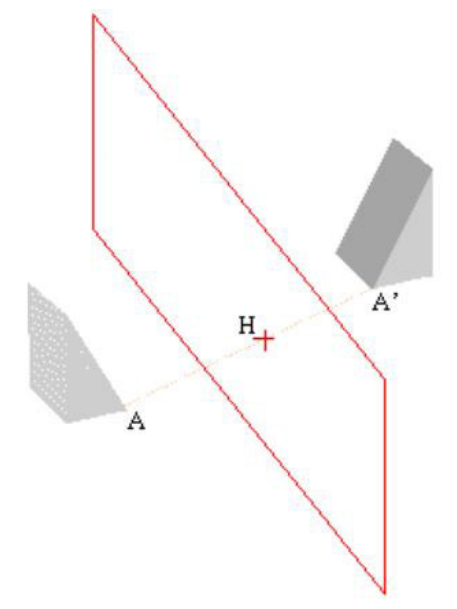

Figura 166. Representació de dos prismes triangulars homòlegs per una simetria especular

\section{La iniciació a la geometria a l'aula d'infantil}

\subsection{Capacitats per desenvolupar a l'aula d'infantil}

Establir els primers passos de manera adequada a l'educació infantil respecte de les primeres nocions espacials i geomètriques serà l'objectiu del tema que contribuirà a desenvolupar en l'alumnat les capacitats següents:

1. Aplicar les nocions d'orientació estàtica (davant-darrere, dalt-baix, a un costat-a l'altre costat) al propi cos i experimentar la direccionalitat que en sorgeix.

2. Aplicar les nocions d'orientació espacial a la situació del propi cos i dels objectes.

2.1. Situar objectes en l'espai i reconèixer la situació dels objectes en relació amb el propi cos.

2.2. Situar-se en l'espai i reconèixer la situació del propi cos en relació amb els objectes. 
2.3. Situar objectes en l'espai i reconèixer les seues posicions en relació amb altres objectes.

3. Aplicar les nocions d'orientació espacial al treball amb representacions gràfiques.

4. Recórrer, reconèixer, construir i dibuixar trajectes i laberints.

5. Reconèixer i reproduir l'ordre espacial: lineal i cíclic.

6. Iniciar una primera aproximació intuïtiva a les nocions de punt, línia, superfície i espai. Reconèixer línies, superfícies i volums en l'espai que ens envolta.

7. Distingir línies i superfícies obertes i tancades. Construir línies i superfícies obertes i tancades i modificar la seua forma i longitud sense alterar la seua propietat.

8. Experimentar les nocions «dins» $\mathrm{i}$ «fora» en relació amb els termes «obert» i «tancat». Adquirir les nocions de frontera i regió.

9. Distingir, construir i representar línies rectes i corbes. Distingir l'horitzontalitat o verticalitat de la línia recta.

10. Experimentar la intersecció de línies. Reconéixer nusos i xarxes.

11. Distingir i construir superfícies planes i corbes.

12. Reconèixer, nomenar, construir i representar les figures geomètriques planes: cercle, triangle, quadrat i rectangle.

13. Reconèixer i nomenar els cossos geomètrics: cub i esfera.

14. Compondre i descompondre figures i cossos geomètrics.

15. Iniciar la idea de simetria en el propi cos, en figures planes i en cossos qualssevol.

16. Organitzar trencaclosques, puzles, sanefes, etc.

\subsection{Desenvolupament de les capacitats}

Novament amb les mateixes consideracions de l'apartat 3.3 del tema 1, estudiarem a continuació els procediments per a construir els primers conceptes referents a nocions espacials i geomètriques a l'aula d'infantil.

1. Aplicar les nocions d'orientació estàtica (davant-darrere, dalt-baix, a un costat-a l'altre costat) al propi cos $i$ experimentar la direccionalitat que en sorgeix

L'espai en el qual vivim té tres dimensions. Això vol dir que una vegada situats enlloc, podríem considerar que som l'origen del gràfic que es mostra a la figura 167.

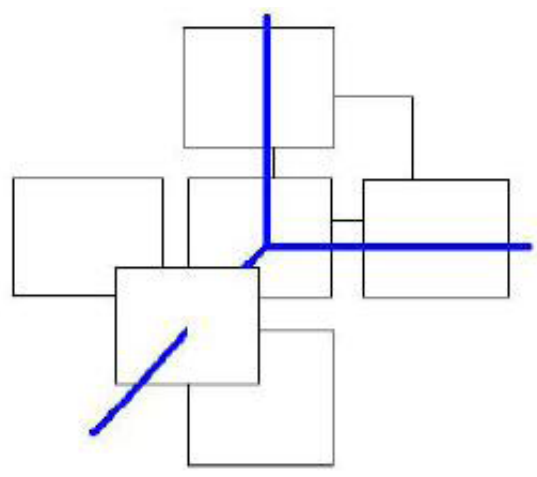

Figura 167. Representació d'un sistema tridimensional d'eixos 
Aleshores és important, en un primer moment, saber anomenar les posicions que inicialment ens situaran en aquest espai i ens permetran relacionar-nos amb ell $\mathrm{i}$ amb tot el que hi ha al nostre voltant. Les posicions que apareixen en aquesta capacitat, davant i darrere, dalt i baix, a un costat i a l'altre, són les primeres que es treballen perquè ofereixen a l'alumnat un conjunt de tres eixos ortogonals en el seu propi cos, que és el sistema de referència de l'espai tridimensional en el qual viuen. És evident que no usarem aquest vocabulari a l'aula d'infantil, però el que s'intenta és configurar aquesta visió espacial amb el sistema de referència, a partir d'activitats adequades al seu desenvolupament cognitiu.

Començarem des de ben petits amb el reconeixement per part de l'alumnat de les parts del seu cos que tenen al davant i les que tenen al darrere. Les indicacions poden ser molt elementals: el que està al davant és la cara, els genolls, el melic..., allò que està en la mateixa part que els ulls i que poden veure amb facilitat, mentre que allò que hi ha al darrere és l'esquena, el cul..., el que no hi podem veure fàcilment $i$ es troba en la part contrària que els ulls (figura 168).

Més endavant i tenint com a referència la cintura, observaran quines parts del seu cos estan a dalt i quines a baix, treballant amb indicacions de l'estil anterior: el cap està dalt, els peus baix, les espatlles dalt, els genolls baix... (figura 168).

Com a complement de les posicions assenyalades fins ara i cap a la meitat del $2 \mathrm{n}$ cicle d'educació infantil, hem de treballar també en els xiquets i les xiquetes el descobriment dels dos costats del seu cos. No es parla de simetria, però s'utilitza la que està present en ells i elles. Es tracta d'observar que algunes parts que hi ha a un costat estan també a l'altre: les mans, els peus, les orelles... Ens podem ajudar d'un espill, en el qual haurem posat un fil o una ratlla que represente l'eix de simetria o també d'un cordó que se subjecte en el front de l'infant i caiga verticalment fins a terra marcant l'esmentat eix per tal que puguen situar les parts del seu cos que es troben "a un costat o a l'altre» (figura 168). Per concretar aquestes posicions i anomenar-les de manera clara i diferenciada introduirem, en el darrer curs de l'etapa, els mots esquerra i dreta per a referir-nos a elles. Si els xiquets i les xiquetes tingueren problemes per a associar adequadament cada paraula amb el costat corresponent, podem utilitzar algun senyal en una de les dues mans per a ajudar-los a recordar-ho (un gomet, un llaç, una creu pintada...).

Cal dir que aquests conceptes resulten molt més complicats per a l'alumnat que els de davant i darrere o dalt i baix esmentats anteriorment. L'explicació d'aquesta dificultat resideix en la simetria, que fa que el seu cos es desenvolupe de la mateixa manera a un costat i a l'altre. Estem posant dos noms diferents a posicions que no els ho semblen. Aquest és el motiu de la confusió entre dreta i esquerra que desapareix normalment en els primers cursos d'educació primària. 

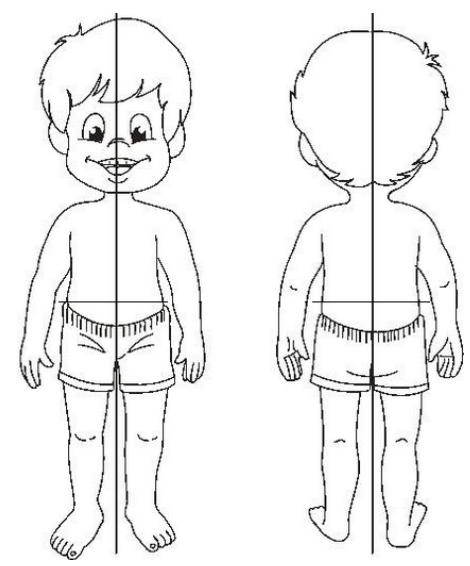

Figura 168. Representació de les nocions d'orientació estàtica en el cos d'un nen

Segons van identificant les diferents nocions d'orientació espacial treballades sobre el cos, es complementa el seu coneixement amb activitats en les quals els xiquets i les xiquetes mouen tot el cos o una de les seues parts d'acord amb alguna de les direccions determinades per les posicions estudiades. Així, en el seus moviments habituals, utilitzarem indicacions del tipus "fes un pas endavant», "posa els braços cap amunt» o "mou el cap a un costat», per exemple, amb la intenció que ells mateixos usen també aquestes formes d'expressar la direccionalitat en la que es mouen.

\section{Aplicar les nocions d'orientació espacial a la situació del propi cos $i$ dels objectes}

Aquesta capacitat amplia a l'espai exterior les nocions d'orientació estàtica esmentades en l'anterior punt i introdueix altres de noves que permeten a l'alumnat organitzar correctament l'espai que els envolta i tot el que aquest conté.

Se subdivideix en tres apartats que estableixen diferències entre les nocions treballades, segons siga un xiquet o una xiqueta el punt de referència per estudiar les posicions dels objectes, un objecte el punt de referència per a les posicions de l'alumnat o un objecte el punt de referència per a les posicions d'altres objectes.

D'acord amb aquestes consideracions, els apartats seran els següents:

2.1. Situar objectes en l'espai i reconèixer la situació dels objectes en relació amb el propi cos (per exemple: posa la cadira darrere de tu; porta el paper que tens al davant).

2.2. Situar-se en l'espai i reconèixer la situació del propi cos en relació amb els objectes (per exemple: posa't al darrere de la porta; de totes les pilotes, porta aquella de la que estàs a prop).

2.3. Situar objectes en l'espai i reconèixer les seues posicions en relació amb altres objectes (per exemple: posa la paperera darrere de la porta; porta la carpeta que hi ha damunt de la taula). 
Per a desenvolupar aquests apartats, i com a criteri general, es considera convenient prestar atenció en primer lloc a activitats de situar objectes o situar-se en diferents posicions i, més endavant, treballar les del seu reconeixement. Es connectarà tot el treball amb les situacions quotidianes que es presenten en diferents moments de la jornada escolar i s'incorporarà a la parla de l'alumnat el vocabulari corresponent de la manera més natural possible.

Es començarà el $2 \mathrm{n}$ cicle d'educació infantil desenvolupant els apartats 2.1 i 2.2 amb les posicions següents:

- Davant, darrere: partirem de les mateixes nocions d'orientació estàtica i identificaran aquestes posicions en l'espai associant-les respectivament a la zona del mateix que poden veure sense girar-se i a la que no.

- Dalt, baix: de manera anàloga al cas anterior, identificaran aquestes posicions associant-les respectivament a la zona de l'espai que queda en un pla superior al seu cap o inferior als seus peus.

- Damunt, davall: per a treballar aquestes posicions és molt important aclarir les relacions $i$ diferències que existeixen entre elles $i$ les de dalt $i$ baix esmentades abans. Parlarem de damunt i davall quan els elements se situen per dalt o per baix d'altres i tinguen una vertical comú amb ells. Per exemple, "la pilota t'ha caigut baix del ribàs», l'objecte, pilota, està en un pla inferior al que situem com a referència, el ribàs, però pot haver una superfície molt gran on trobar-la. Mentre que si la indicació és «la pilota t’ha caigut a sota del pont», caldrà buscar-la només a la superfície que cobreix el pont. Cal notar que sempre que un element estiga damunt (davall) d'un altre, està també dalt (baix) del mateix, però no és cert al contrari en tots els casos.

Per a treballar totes aquestes nocions cal tenir una atenció especial a la posició dels nens i de les nenes, que ha de ser sempre vertical (dret, assegut, agenollat...) però mai tombat, que seria horitzontal, on les intuïcions de dalt, baix, damunt, davall, etc., varien molt i poden conduir a confusió.

- Prop, lluny: en aquest cas les consideracions al respecte poden ser molt variades, ja que no són conceptes absoluts, però en aquestes edats es pot arribar al consens que estarà prop qualsevol element que puguen agafar sense moure's del lloc on es troben, mentre que per tal d'agafar un objecte que es troba lluny, han d'iniciar un moviment que els faça desplaçar-se.

Cap a la meitat del cicle caldrà ampliar les nocions d'orientació espacial treballades en els dos primers apartats introduint les següents posicions espacials:

- A un costat, a l'altre costat: novament partirem de les mateixes nocions d'orientació estàtica i identificaran aquestes posicions en l'espai associant-les respectivament a les zones del mateix que s'estenen a partir de cadascun dels costats del seu propi cos.

- Junt, separat: en aquest cas i per a establir clarament la diferència entre les dues posicions, es considerarà que dues persones o objectes estan junts o separats en funció de l'existència o no de contacte real i permanent entre ells. 
- Estar entre: per tal d'establir aquesta nova posició espacial i a diferència de les anteriors es necessiten almenys tres elements. Es dirà que un objecte es troba entre altres dos quan en té un a cadascun dels seu costats o un davant $i$ l'altre darrere.

- Al voltant: considerarem ara diversos elements respecte d'un altre per tal de parlar d'aquesta posició. Els elements que es troben al voltant d'un altre ocupen diferents posicions individuals respecte del mateix, però considerats en conjunt es situen de manera que aquest està, més o menys, en el centre de tots ells. Per poder parlar d'aquesta posició és necessari que hi hagen, almenys, quatre elements.

- Enfront de: per a poder parlar amb propietat d'aquesta posició és necessari que els elements considerats tinguen una part davantera clara. En aquest cas, direm que estan un enfront de l'altre quan, a banda de trobar-se un davant de l'altre, estiguen cara a cara, és a dir, cadascun puga veure la part davantera de l'altre, si aquesta existeix clarament.

En el moment que estiga prou avançat el coneixement de les nocions d'orientació espacial referides als dos primers apartats en els quals els xiquets i les xiquetes són un dels elements que intervenen directament en les posicions estudiades, anirem treballant en l'apartat 2.3 totes aquestes posicions però ara referides exclusivament a objectes respecte a objectes. És molt important que l'alumnat siga capaç de construir el coneixement de les posicions en les quals el seu cos és un dels elements per a poder estendre-ho després a les posicions generals entre objectes i poder així organitzar adequadament tot l'espai que els envolta. A més de treballar amb els objectes de l'entorn, podem ajudar-nos de materials didàctics específics, com el que es mostra en la figura 169 , amb què poden crear i reproduir totes les posicions espacials abans esmentades.

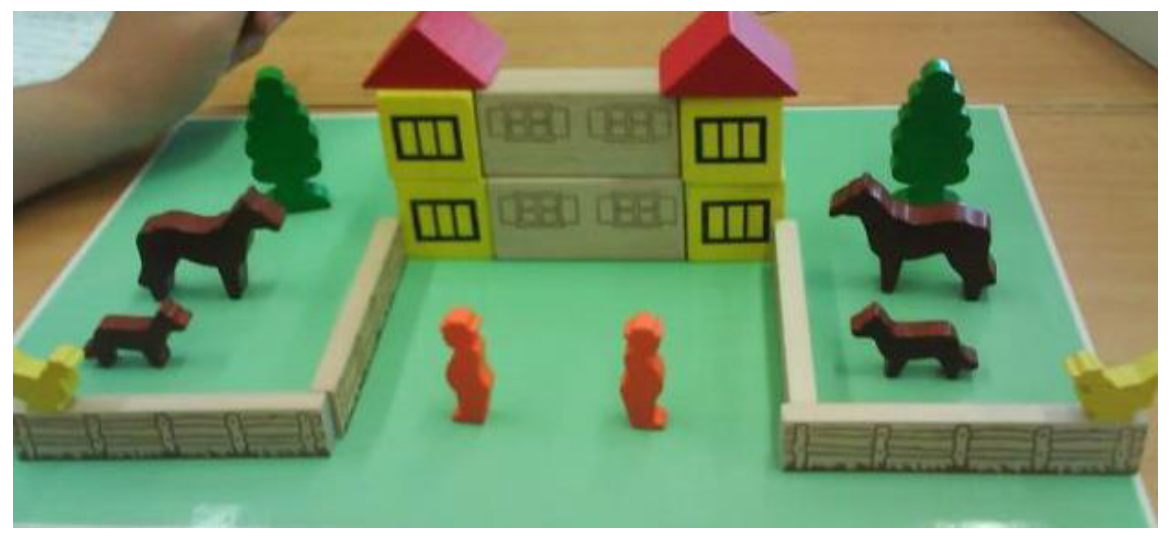

Figura 169. Taller de Topologia 2 (fabricat per Nathan)

Per completar aquesta capacitat i ja en l'últim curs de l'etapa el treball es dirigirà, a més de reforçar totes les nocions estudiades en els cursos anteriors, a ampliar-les amb la introducció d'esquerra i dreta que, a partir del seu propi cos, s'encaminarà a intentar que els xiquets $i$ les xiquetes projecten la seua lateralitat en els altres elements que hi ha en l'espai. És un treball molt important i que presenta moltes dificultats per tal de construir amb claredat la lateralitat de les altres persones i la 
de l'espai en general i no es pot desenvolupar adequadament si no està ben construïda la lateralitat pròpia de l'alumnat.

\section{Aplicar les nocions d'orientació espacial al treball amb representacions gràfiques}

L'objectiu és ara traslladar les posicions espacials estudiades en les capacitats anteriors al treball amb representacions gràfiques, sabent que és necessari construir aquests conceptes primer en la realitat per després passar al paper.

L'alumnat no podrà començar a desenvolupar adequadament aquesta capacitat fins que no s'haja treballat en la realitat el tercer apartat de la capacitat anterior. Això no vol dir que abans els xiquets i les xiquetes no dibuixen o pinten, però no podem esperar correcció i fidelitat en les seues representacions pels nivells cognitius i de motricitat que abasten.

Cal intentar que l'alumnat inicie aquest treball amb representacions de situacions (jocs o activitats) acabades de fer, que tinguen utilitat per a guardar-les, recordar-les, mostrar-les a uns altres, etc. (es podria relacionar aquesta activitat amb la representació de seqüències temporals esmentada en el tema anterior). Més endavant el treball gràfic no necessariament haurà d'estar associat a cap activitat real.

Seguint l'ordre dels apartats 2.1, 2.2 i 2.3 de la capacitat anterior, treballarem al principi sobre dibuixos en els quals aparega la imatge d'un xiquet o una xiqueta. Es tracta que l'alumnat s'identifique amb la imatge i represente o reconega posicions d'objectes respecte d'ell o ella. Per exemple, «en una representació del pati del col·legi en la qual es troba el xiquet, se li demana que dibuixe el pal que tenia al seu costat quan jugàvem a futbol», «en una representació de l'aula on es troba la imatge del xiquet $i$ altres objectes, li demanem que pinte de roig la prestatgeria que està lluny d'ell o ella».

A continuació els punts de referència seran els objectes representats i l'alumnat haurà de dibuixar la seua imatge o reconèixer la seua posició respecte d'ells. Les activitats seran del tipus «pinta't a prop de la cistella», en un dibuix del pati on es juga a bàsquet $\mathrm{o}$ "racoloreix la teua imatge que hi ha damunt del banc que acabes de saltar», en una representació del gimnàs del col·legi on poden aparèixer més xiquets $i$ xiquetes en altres posicions. Més tard passarem al treball en què sols intervenen objectes mitjançant activitats com "pinta damunt de la taula de la mestra la caixa de llibres que hem estat buidant abans», en una representació de l'aula de classe o "pinta l'estrella que hi ha damunt del cap de la vaca», en una imatge nocturna d'una granja (figura 170). 


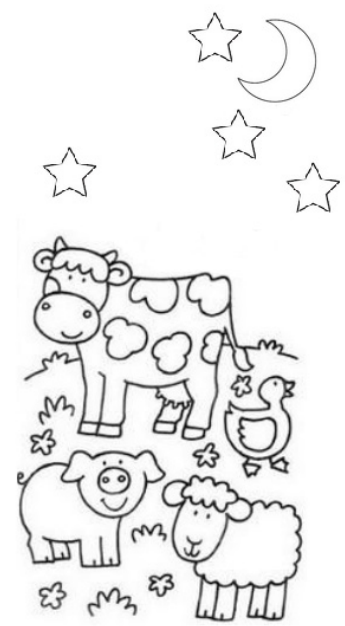

Figura 170. Imatge infantil nocturna d'uns animals de granja

També tindrem en compte la conveniència d'oferir-los al principi imatges inicials a partir de les quals desenvolupen la seua representació i de deixar que dibuixen sense cap pista per la nostra part més endavant.

Hem de tenir una especial atenció amb les representacions de «darrere de» o «al voltant de» per la seua especial dificultat. En el primer dels casos, serà necessari que en el dibuix sobreïsca una part de l'objecte que estiga al darrere d'un altre (figura 171).

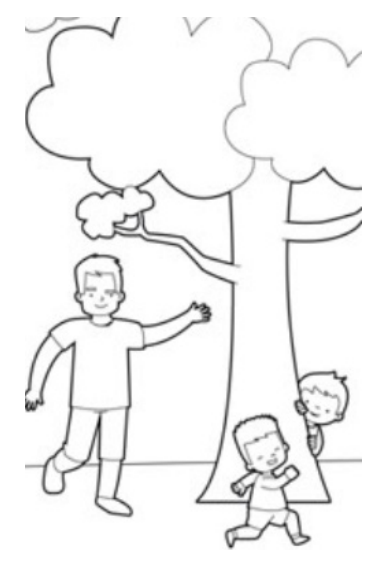

Figura 171. Imatge de xiquets davant i darrere d'un arbre

En el segon es pot confondre amb una representació de dalt i baix si no s'han realitzat suficients activitats reals amb aquesta posició i l'alumnat no té suficient destresa per a interpretar i dibuixar la perspectiva. Per a resoldre aquest problema podem situar les criatures jugant en rogle al voltant d'una xiqueta i a sobre d'un paper continu. Un altre nen o nena marcarà amb un cercle les posicions dels seus companys i companyes i la de la xiqueta central. Després d'observar aquesta representació amb el paper en horitzontal, el canviarem a la posició vertical per adonar-nos que el que ara semblen altres posicions (en aquest cas dalt, baix, esquerra i dreta) és en realitat la manera de representar «al voltant» de la nena central. 

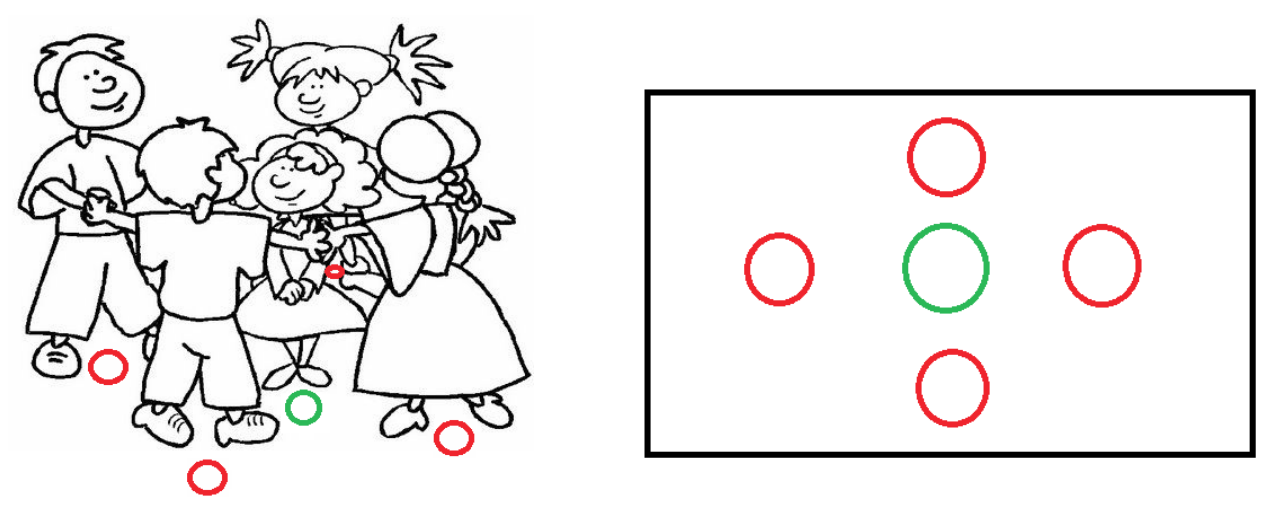

Figura 172. Imatge d'un rogle de xiquets i xiquetes (esquerra) i la representació simbòlica de la posició «al voltant de» (dreta)

\section{Recórrer, reconèixer, construir i dibuixar trajectes i laberints}

En aquesta capacitat continuem amb el coneixement de l'organització espacial incorporant les diferents possibilitats de moviment que l'alumnat pot desenvolupar a partir dels seus desplaçaments dins de l'espai.

En aquest sentit i de manera intuïtiva, entendrem com a trajecte, recorregut o itinerari un camí perfectament determinat que es pot recórrer des d'un punt inicial fins a un final sense necessitat de retrocedir en cap moment, i com a laberint un recorregut que no està determinat en el qual s'hi poden trobar obstacles que obliguen a retrocedir i buscar un tram del camí alternatiu al qual no es pot recórrer. Es pot considerar el treball amb laberints com una manera d'aplicar les possibilitats de moviment per l'espai que s'aprenen amb les activitats de trajectes o recorreguts.

Iniciarem aquest treball cap al final del $1 \mathrm{r}$ cicle d'educació infantil i en el primer curs del $2 \mathrm{n}$ cicle, amb jocs en els quals l'alumnat haja de recórrer trajectes senzills marcats en terra amb pals, cordes, etc., mitjançant activitats de reomplir amb les mans o els peus banyats de pintura alguns camins marcats sobre paper continu o de desplaçar-se per l'espai d'acord amb algunes instruccions del docent (corrent, saltant, caminant cap enrere...).

Cap a la meitat del $2 \mathrm{n}$ cicle caldrà complicar un poc més els recorreguts i les indicacions, iniciant també el treball amb representacions gràfiques. Més endavant introduirem els laberints amb objectes reals (caixes de cartró, mobiliari escolar, etc.) per tal de passar després al format gràfic.

Es poden organitzar recorreguts i laberints dins l'aula, en l'edifici del col·legi o en el pati, en el barri o en el poble. En el cas dels trajectes hi ha diferents maneres de treballar:

1. Recórrer un camí real sense prendre nota del que s'ha recorregut, simplement senyalitzant amb cordes o línies el trajecte per on es passa i verbalitzant els diferents moviments i canvis de direcció. 
2. Completar l'activitat anterior amb la representació gràfica del recorregut en el plànol de manera simultània al desplaçament.

3. Recórrer un camí a partir de les indicacions verbals o gràfiques (plànol) que han estat proporcionades pel docent, en un primer moment, o un altre grup de companys més endavant.

4. Recórrer un camí en la realitat i, després de realitzar l'activitat, assenyalar el trajecte sobre el plànol corresponent verbalitzant els diferents moviments realitzats.

En el cas dels laberints, hi trobem:

1. Recórrer un laberint real, fet a classe per la mestra o el mestre, amb taules $i$ cadires, amb caixes buides (per exemple d'electrodomèstics), etc.

2. Completar l'activitat anterior amb la representació gràfica del laberint en el plànol de manera simultània al desplaçament.

3. Recórrer un laberint en la realitat i, després de realitzar l'activitat, assenyalar el recorregut seguit sobre l'esquema del laberint i verbalitzar els diferents moviments realitzats.

4. A partir d'un laberint representat gràficament, assenyalar-hi el camí adequat per anar del punt d'eixida al punt d'arribada, i verbalitzar els diferents moviments realitzats.

Un material didàctic que ens pot ajudar a desenvolupar aquest treball és l'anomenat Pistes màgiques 1 i 2 (figura 173), que ens ofereix diferents camins i laberints representats en relleu sobre superfícies de plàstic. L'alumnat els recorrerà amb el dit, amb un retolador, amb el ninotet que acompanya el material o amb un iman que mourà l'esmentat ninotet des de la part de davall de les safates.
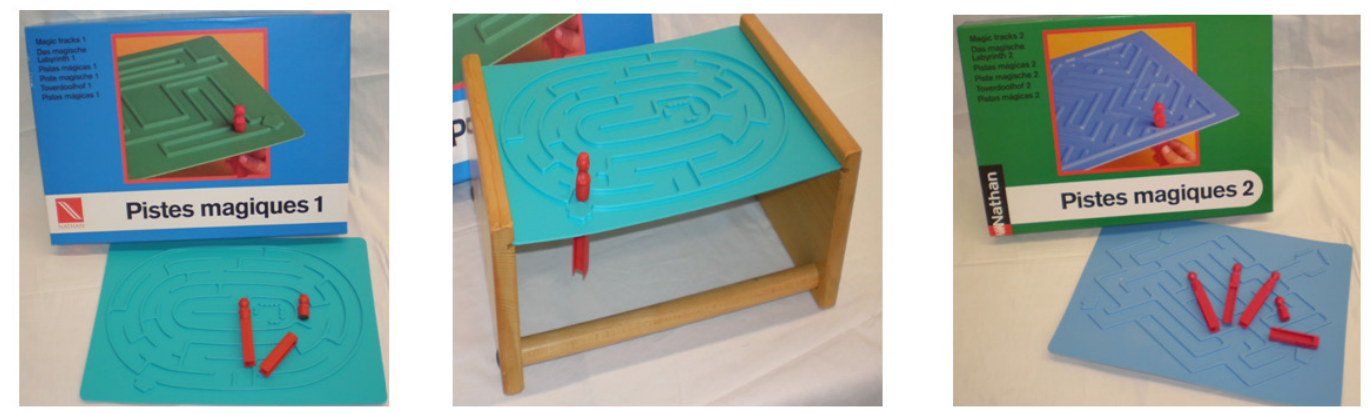

Figura 173. Pistes màgiques 1 i 2 (fabricat per Nathan)

Un altre material que també pot ser útil per aquest treball és el Geoplà. Consisteix en una superfície plana quadrada i rígida en la qual hi ha una xarxa de pivots als quals es poden enganxar gomes elàstiques per a representar-hi diferents figures geomètriques planes. Segons la disposició dels pivots, els geoplans poden ser: de xarxa quadrada (els pivots hi ocupen vèrtexs de quadrats iguals), de xarxa triangular o isomètrica (els pivots hi ocupen vèrtexs de triangles equilàters iguals) $i \mathrm{de}$ xarxa circular (els pivots hi ocupen punts equidistants d'una o diverses circumferències concèntriques) com es mostren a la figura 174 . 

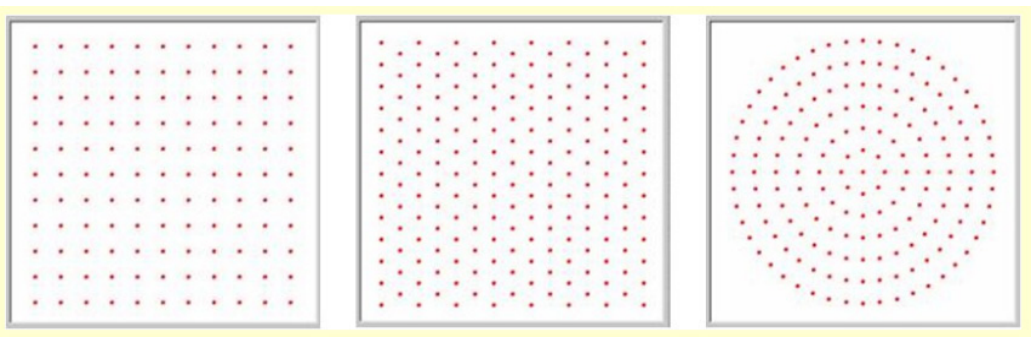

Figura 174. Representació de les malles de tres geoplans: quadrangular (esquerra), triangular (centre) i circular (dreta)

Amb la utilització d'aquest material, l'alumnat pot construir diferents trajectes i laberints amb els elàstics i, posteriorment, recórrer-los amb el dit o amb algun objecte per a escriure (guix, retolador...), com es pot veure en la figura 175.

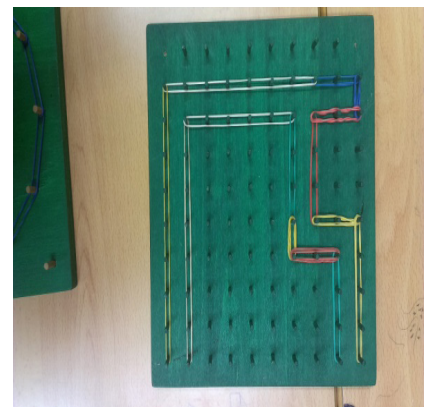

Figura 175. Representació d'un trajecte elaborat amb elàstics en un geoplà

També cal intentar, cap al final de l'etapa, que ells i elles puguen arribar a construir els seus propis laberints (tant en la realitat com gràficament); per exemple, dissenyant-los en grups, per a resoldre'ls individualment o per part d'un altre grup.

\section{Reconèixer i reproduir l'ordre espacial: lineal i cíclic}

Comencem en aquesta capacitat amb el desenvolupament dels conceptes topològics a l'aula. L'objectiu que ens plantegem ara és reconèixer i reproduir les posicions d'alguns punts en l'espai (que per a l'alumnat es materialitzaran en persones, objectes...) i la seua ordenació.

Per a treballar aquests conceptes distingirem entre ordre lineal i ordre cíclic. Així, parlarem d'ordre lineal quan els punts considerats es troben a sobre d'una línia oberta i d'ordre cíclic quan els punts considerats es troben a sobre d'una línia tancada. També diferenciarem ordre directe i ordre invers, segons si la reproducció de l'ordre inicial del punts es fa respectant totes les seues posicions o intercanviant les del primer i l'últim i amb ells les posicions de tots els altres, respectivament.

Començarem el $2 \mathrm{n}$ cicle d'educació infantil treballant amb l'alumnat l'ordre lineal directe en situacions properes i molt senzilles, on han de reproduir una ordenació inicial de punts que els donem com a model. Per exemple, si per preparar la festivitat 
de carnaval tenim una filera de xiquets disfressats de pirata, bomber, indi, jardiner i metge i una altra filera del mateix nombre de xiquetes sense disfressar, l'activitat consisteix en què un alumne o alumna ha de donar a les xiquetes els vestits que necessiten per a disfressar-se de la mateixa manera $i$ en el mateix ordre que els seus companys.

En les primeres activitats d'aquest tipus els marcarem les posicions de les imatges dels punts dels quals partim (com s'ha explicat en l'exemple anterior) i més endavant ja no ho farem (les xiquetes no formaran una fila des del primer moment, sinó que s'aniran posant en el seu lloc a mesura que es desenvolupa l'activitat).

També tindrem en compte, en un primer moment, la necessitat de treballar amb alineacions del mateix tipus, orientades de la mateixa manera respecte del xiquet $o$ xiqueta que realitza l'activitat i mantenint distàncies semblants entre els punts originals i entre les seues imatges. En el cas de les disfresses, per exemple, l'alumne o alumna que reparteix els vestits als seus companys observarà les dues files des d'una única posició, sense necessitat de girar-se per passar d'una filera a l'altra (figura 176).

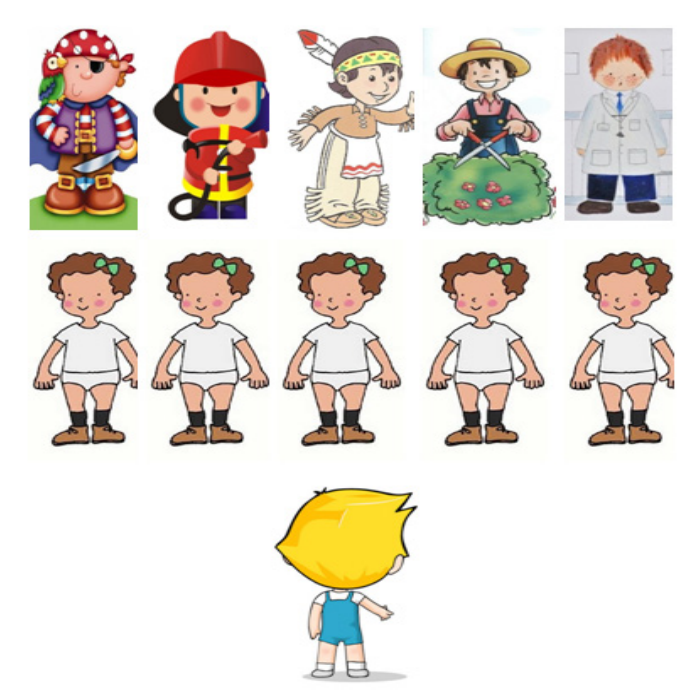

Figura 176. Representació de la reproducció d'un ordre lineal directe

Cap a la meitat del cicle es poden incorporar variacions en els tipus de línies (combinant rectes $i$ corbes en les posicions dels punts de partida $i$ en les de les seues imatges) $i$ en les distàncies entre els punts, a més de realitzar activitats en les quals l'alumnat haja de reproduir gràficament un ordre de punts conegut també mitjançant una representació gràfica (copiar objectes d'un dibuix en un ordre determinat, dibuixar sanefes, etc.).

Més endavant, es pot treballar transformant posicions de punts situats sobre línies horitzontals en altres que ocupen línies verticals, tant en situacions reals com gràfiques. Per exemple, si estem ordenant una comanda de material escolar que ens ha arribat a l'aula, hauran d'apilar pastilles de plastilina en el mateix ordre de 
colors que apareix en una filera de paquets de cartolines que ja han guardat en una prestatgeria de la classe (figura 177).

Figura 177. Representació de la reproducció d'un ordre lineal en horitzontal a un altre en vertical

Al llarg de totes aquestes activitats hem de potenciar la verbalització per part de l'alumnat de les posicions que ocupen els diferents punts que intervenen en elles, utilitzant el vocabulari associat: «primer», «últim», «anterior», «posterior», «entre», «al costat», «a l'esquerra»...

Conjuntament amb l'avanç en el coneixement de l'ordre lineal directe i també cap a la meitat del $2 \mathrm{n}$ cicle hem d'iniciar l'ordre cíclic, treballant anàlogament $\mathrm{amb}$ xiquets i xiquetes i objectes de l'entorn. La dificultat és ara major ja que els punts se situen a sobre de línies tancades i, per tant, no hi ha principi ni final preestablert. Per reproduir en aquests casos l'ordre espacial cal establir quin serà el primer element $i$ en quin sentit ens desplaçarem per la línia tancada per a determinar l'ordre a reproduir. En un principi, el treball consistirà a traslladar les posicions d'una línia tancada a una altra amb la mateixa forma i mantenint les distàncies entre els punts. Com en el cas de l'ordre lineal, caldrà trobar exemples que els puguen ser propers, podent ser vàlids els mateixos que hem comentat abans modificant el tipus de línia on es situen els punts. Per exemple, els xiquets i les xiquetes de la figura 176, en compte de fer una filera poden formar un rogle.

Més endavant, ampliarem l'estudi de l'ordre cíclic combinant línies tancades de diferents tipus (circumferències, el·lipses, ovoïdals, poligonals...) i variant les distàncies entre els punts originals i entre les seues imatges. També dedicarem atenció a les representacions gràfiques d'aquest tipus d'orde espacial, demanant-los, per exemple que pinten estrelles per a decorar l'aula seguint un model que els donarem (figura 178).
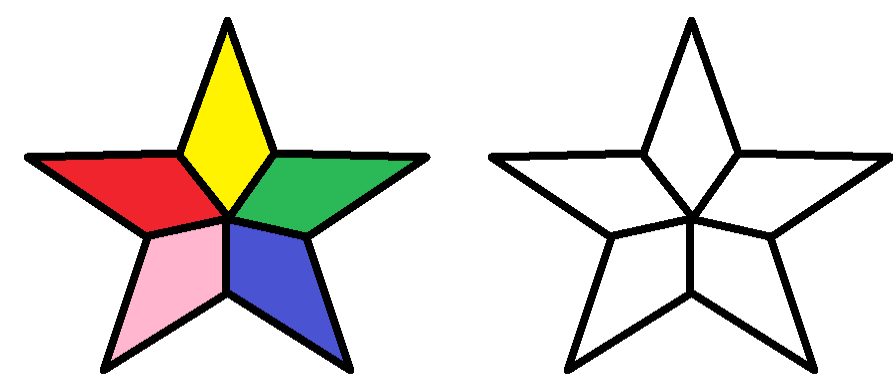

Figura 178. Representació d'estrelles per reproduir un ordre cíclic

En l'últim curs de l'etapa completarem tot el treball anterior combinant l'ordre lineal directe i l'ordre cíclic, situant els punts dels quals partim sobre línies obertes i els punts imatge sobre línies tancades o a l'inrevés (per exemple, copiar un collar tancat enfilant boles en un fil obert). 
Per finalitzar, es podrà introduir l'ordre lineal invers, passant de punts situats sobre línies obertes a uns altres també sobre línies obertes i en la mateixa posició, mantenint invariants les distàncies entre els punts originals i entre les seues imatges, però invertint el seu ordre de col·locació. És convenient realitzar les activitats començant per un nombre imparell de punts de partida, per passar-hi més endavant a un nombre parell. En el primer cas, el punt que ocupa el lloc central no canvia de posició en invertir l'ordre i pot servir d'ajuda per a trobar les posicions de les altres imatges, mentre que no ocorre així en l'altre cas, on totes les imatges canvien de posició respecte de les inicials.

A més dels exemples esmentats anteriorment i per ajudar a contextualitzar aquest treball en situacions reals, podem aprofitar les activitats relacionades amb la capacitat anterior, fent recorreguts tant cíclics com no cíclics que hagen de reproduir en algun plànol, marcant l'ordre de determinats punts del recorregut, i també les relacionades amb la realització de sanefes que veurem en la capacitat 16 d'aquest tema.

\section{Iniciar una primera aproximació intuïtiva a les nocions de punt, línia, superficie i espai. Reconèixer línies, superfícies $i$ volums en l'espai que ens envolta}

Intentarem ara apropar l'alumnat als conceptes geomètrics de punt, línia, superfície i espai a partir de l'entorn i dels objectes que els envolten. Evidentment, en aquesta etapa educativa no podrem arribar a l'abstracció dels esmentats conceptes, sols construirem aproximacions reals als mateixos.

En aquest sentit, és important que el mestre o la mestra tinga clara la diferència entre les seues dimensions. Parlar de dimensions és una abstracció que no entra a l'aula d'infantil, però conèixer-les ens ajudarà a mesurar la dificultat que presenten. Matemàticament, un punt té dimensió 0 , una línia té dimensió 1 , una superfície 2 i l'espai, dimensió 3.

Ens proposem que els xiquets i les xiquetes puguen anar formant-se la seua pròpia imatge mental de les nocions geomètriques estudiades mitjançant activitats de contacte amb objectes reals i de reflexió sobre les seues experiències, que es realitzaran en qualsevol moment relacionades amb altres situacions i activitats de l'aula. També introduirem el vocabulari associat amb la intenció que l'alumnat puga incorporar-lo progressivament al seu i treballarem amb representacions gràfiques dels conceptes estudiats, tenint en compte les limitacions dels nens i nenes d'aquestes edats.

Aquesta capacitat es desenvolupa al llarg de tot el 2n cicle d'educació infantil i el coneixement dels conceptes que la integren s'amplia i complementa amb l'ajuda del treball que es realitza en les restants capacitats del tema. Com que la percepció de l'alumnat és global i l'espai on vivim és tridimensional, començarem per aproximar-nos-hi, continuant després amb les superfícies i les línies fins a arribar, en últim lloc, al punt com el concepte geomètric més simple i que constitueix l'element que compon a tots els demés. 
La primera aproximació a l'espai és reconèixer-lo com l'aire que ens envolta, en el qual estem nosaltres i totes les altres persones i coses. La segona aproximació anirà en relació amb la idea d'espai ocupat per un objecte com una porció de l'espai anterior. Així es construeix la distinció entre espai geomètric «complet», que habitualment és l'espai general, i espai geomètric «particular», ocupat per un cos que es quantifica calculant la mesura del seu volum.

L'alumnat haurà d'observar també que el seu contacte amb l'espai general és complet, que pot moure's dins d'ell i col·locar o desplaçar per ell tot allò que l'envolta. En aquests nivells no es treballarà de manera específica la representació gràfica de l'espai ni dels cossos, per la impossibilitat dels xiquets i les xiquetes de traslladar a les dues dimensions del pla les tres dimensions de l'espai.

En el cas de les superfícies, l'alumnat prendrà contacte amb parets, taules, el terra, pàgines de llibres, teles de vestits, caixes, pots... Novament s'està construint una idea: que la superfície és allò que puc recórrer amb la mà estesa, amb la planta del peu, on puc recolzar-me jo i recolzar altres objectes i damunt de la qual es poden dibuixar punts, línies, objectes, coses...

Relacionat amb diferents situacions d'aula (fer una cabanya, una disfressa, un mural...) treballarem la construcció de diverses superfícies amb paper, tela, cartró, etc., i farem tasques de recobriment d'algunes superfícies amb pintura, boletes de paper, etc.

Posteriorment, intentarem realitzar un treball gràfic, però els resulta complicat també plasmar gràficament les superfícies llevat de quan són planes (es necessita perspectiva en molts casos). Per tant, deixarem que dibuixen el que puguen sense esperar correcció en les seues produccions.

Caldrà posar especial atenció en distingir la superfície d'un cos tridimensional de l'espai ocupat per aquest objecte. La primera és la que es toca, la part de l'objecte que es veu i es pot recórrer amb la mà, la frontera del cos. L'espai que ocupa l'objecte és l'espai geomètric particular que només conté aquest cos.

Podem aproximar-nos a la idea de línia a través del recorregut de camins marcats de diferents maneres, de la formació de fileres amb els xiquets i les xiquetes, de la realització de sèries, de l'enfilament de boletes... També mitjançant activitats amb cordes, fils, vores d'un full, arestes d'alguns objectes, etc., que permeten l'alumnat d'anar construint el concepte de línia. D'aquesta manera els xiquets i les xiquetes observaran que el contacte amb les línies és dinàmic, que poden recórrer-les amb la punta del dit o d'un llapis i que a sobre d'elles no es pot recolzar res i sols es poden dibuixar punts.

Relacionat amb situacions habituals a l'aula (posar les taules en fila, marcar un camí en el terra, dibuixar una casa, encerclar uns objectes...) es treballarà també la construcció de línies i les activitats gràfiques de dibuixar, pintar i repassar línies. 
Per últim, identificarem el punt amb l'extrem de la vora d'un full, d'una caixa...; amb la punta d'un llapis, d'un ganivet, d'unes tisores...; amb la marca d'un llapis en un paper, etc. L'alumnat ha d'observar que el seu contacte amb el punt és mínim, estàtic, i que a sobre d'un punt no es pot recolzar ni dibuixar res.

És important que els xiquets i les xiquetes reconeguen aquests conceptes en objectes de la vida real. Per exemple, a partir d'una caixa qualsevol, hauran d'identificar punts, línies, superfícies i l'espai que hi ocupa (figura 179).

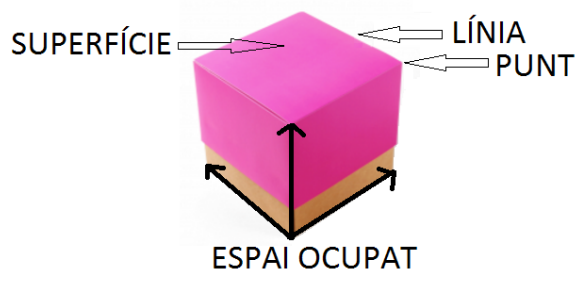

Figura 179. Representació d'una caixa amb indicacions de l'espai que ocupa i d'un punt, una línia, i la superfície d'una de les seues cares

7. Distingir línies i superfícies obertes i tancades. Construir línies $i$ superficies obertes $i$ tancades $i$ modificar la seua forma $i$ longitud sense alterar la seua propietat

D'ara endavant es completarà la capacitat anterior amb l'estudi particular de diferents tipus de línies i superfícies i, a partir d'elles, dels conceptes que se'n deriven: figures planes i cossos geomètrics.

En el 1r curs del cicle i relacionat amb situacions de jocs, d'activitats físiques o d'altres treballs d'aula, l'alumnat realitzarà desplaçaments «des del principi fins al final» per damunt de línies assenyalades en el terra amb pals, cordes, ratlles, etc., observant el que ocorre en funció de l'existència o inexistència d'extrems en les línies. D'acord amb aquestes experiències, si hi ha extrems la línia serà oberta i, en cas contrari, tancada (figura 180). És important introduir la verbalització i usar el vocabulari adequat en cada situació, en principi per part del docent i, a poc a poc, també pels xiquets i les xiquetes.

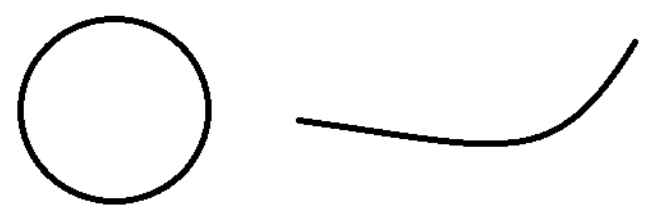

Figura 180. Representació d'una línia tancada (esquerra) i d'una oberta (dreta)

Més endavant, i per comprovar si l'alumnat va elaborant adequadament la seua pròpia imatge mental dels conceptes estudiats, es treballarà la construcció i la 
representació gràfica de línies obertes i tancades, oferint-los al principi un model de referència si el necessiten i sense cap model després.

Cap a la meitat del cicle cal treballar també les superfícies obertes i tancades, a partir del contacte amb elles (teles, papers, cartolines, cartons, caixes..., que es recorren amb les mans) i d'observar que unes tenen extrems que indiquen clarament on comença i on acaba la superfície, les obertes, i d'altres no, les tancades (figura 181). Estendrem l'ús del vocabulari utilitzat per a les línies aplicant-ho també a les superfícies. És important que els xiquets i les xiquetes observen que les superfícies obertes ens deixen recórrer tot l'espai geomètric sense cap problema mentre que les tancades no, sent necessari travessar-les per poder fer-ho (per passar d'una regió a l'altra hem de trencar-les).
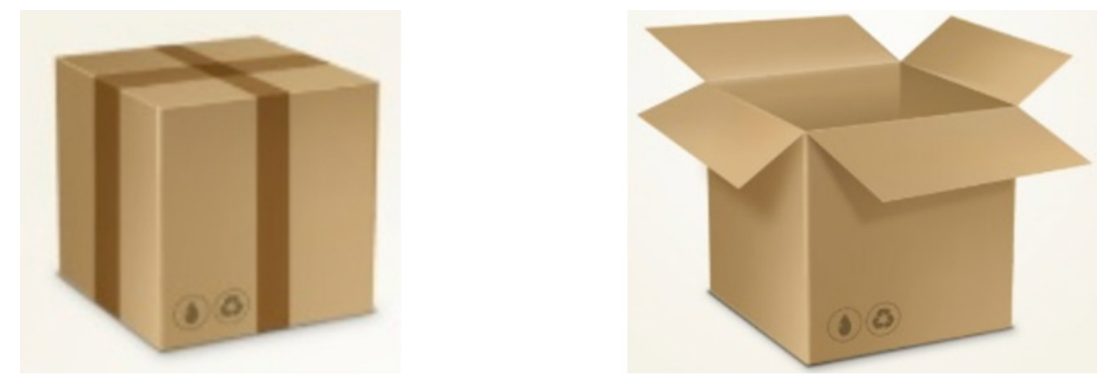

Figura 181. Representació d'una superfície tancada (esquerra) i d'una oberta (dreta)

De manera anàloga al cas de les línies i relacionat amb algunes situacions d'aula, es treballarà la construcció de superfícies obertes i tancades, oferint-los al principi un model de referència si el necessiten i sense cap model després. Com ja hem comentat en la capacitat anterior, existeixen moltes dificultats per poder treballar adequadament la representació gràfica de superfícies, per tant, continuarem deixant-los dibuixar sense esperar fidelitat i correcció total en les seues produccions.

Per últim, i com a complement de tot el que ja hem comentat, cal realitzar també activitats de construcció de línies i superfícies obertes i tancades, en les quals haja de modificar-se la forma o longitud d'unes altres que s'hi donen inicialment, però conservant el seu caràcter d'obertes o tancades (per exemple, corda més llarga per nugar un paquet, collar més curt, barret de fada més petit, cartolina més gran...).

Els conceptes estudiats en aquesta capacitat s'amplien i complementen amb el treball de la capacitat següent.

8. Experimentar les nocions «dins» $i$ «fora» en relació amb els termes «obert» $i$ «tancat». Adquirir les nocions de frontera i regió

Per a desenvolupar aquesta capacitat es fa necessari parlar del concepte de frontera com un conjunt de punts que separa una línia, una superficie o l'espai en dues regions clarament diferenciades i que és necessari travessar per anar d'una regió a l'altra. 
La definició anterior va irremeiablement unida al concepte geomètric respecte del qual considerem la frontera, per això, si parlem de l'espai, que té dimensió 3, el que definirà la frontera serà una superfície tancada, que és de dimensió 2 (la d'una caixa tapada, la d'un armari tancat, etc.). En el cas de les superfícies, la frontera vindrà determinada per una línia tancada, que té dimensió 1 (la circumferència del cercle central d'un camp de futbol, un diagrama de Venn, etc.). Podem trobar superfícies a sobre les quals algunes línies tancades no són frontera (per exemple, en la superfície d'un flotador, com el que es mostra en la figura 182, cadascuna de les línies tancades representades no forma frontera per si mateixa), però no són objecte d'estudi en aquesta etapa.

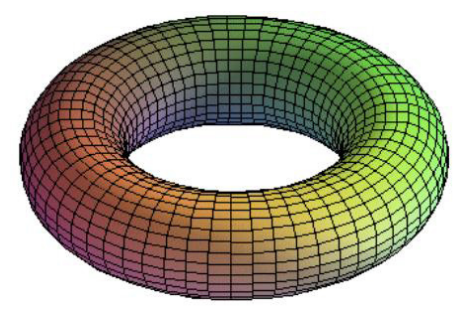

Figura 182. Representació d'una superfície toroïdal

Per últim, quan es tracte de línies (figura 183), la frontera vindrà determinada per un punt, que és de dimensió 0 , en el cas de les obertes i dos punts no consecutius en el de les tancades (per exemple, establir dos trams en les boles d'un collar obert o tancat, etc.).

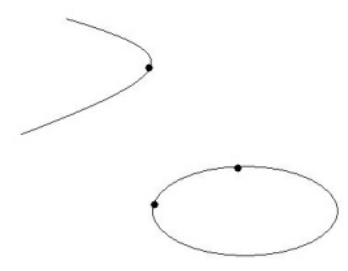

Figura 183. Representació de fronteres en línies

La idea de frontera que es va construint l'alumnat és que no es pot passar d'una a l'altra zona si no es travessa la frontera. La importància d'aquest concepte rau en la seua utilitat per a establir els límits de les figures planes i dels cossos geomètrics i, per tant, per a reconèixer-los, definir-los, estudiar-los i caracteritzar-los.

Començarem des del principi del $2 \mathrm{n}$ cicle $\mathrm{i}$, a partir del moviment $\mathrm{i}$ de les posicions dels xiquets $i$ les xiquetes, introduirem les nocions «dins» $\mathrm{i}$ «fora» respecte d'una superfície tancada, que serà una frontera en l'espai (caixa, armari, aula...), per a treballar-les a continuació amb objectes i amb altres fronteres (ampolla, bossa, estoig...).

En tots els casos es verbalitzaran les posicions que es treballen utilitzant el vocabulari associat, en primer lloc per part del docent i després també per l'alumnat. Hem d'intentar evitar algunes confusions prou habituals en el llenguatge: «dins» no 
és igual a «en» (l'aigua es troba «en» el got, no «dins» del got, què és una superfície oberta; però «dins» l'ampolla tapada, no «en» l'ampolla tapada, què és una superfície tancada). És a dir, només es pot parlar de dins i fora quan existeix realment una frontera. En qualsevol altre cas aquestes paraules no són correctes.

A més del treball amb fronteres en l'espai que acabem de comentar, prestarem atenció també, des del principi del cicle, a les nocions dins i fora respecte d'una línia tancada, que ara serà frontera en una superfície: xafar dins/fora d'un cèrcol, recolzar una pilota dins/fora de la línia tancada d'un camp de deport, etc. En aquests casos hem de procurar no utilitzar expressions incorrectes: per exemple, demanar a un xiquet o xiqueta que es pose o que col·loque un objecte, dins d'una línia tancada; és impossible que qualsevol cosa de 3 dimensions estiga dins d'una altra de 2. Haurem de dir «xafa dins del cèrcol»o «recolza el llibre dins de la línia». És convenient treballar primer les fronteres en superfícies planes i després en altres que no ho siguen (una pilota, una cabanya...) per a comprovar que sempre que necessitem una frontera en una superfície hem de treballar amb una línia tancada.

Posteriorment al treball manipulatiu es farà un de gràfic amb les fronteres en una superfície: acolorir dins/fora de la silueta d'un dibuix, acolorir dins/fora del contorn de les figures geomètriques planes, etc.

Cap a la meitat del cicle cal ampliar el vocabulari inicial, introduint-hi les paraules zona o regió (per a referir-se a cadascuna de les parts en què es divideix l'espai o una superfície) i frontera (com l'element que separa dues zones o regions). Com en altres ocasions, serà el docent qui utilitze el vocabulari en un primer moment per a passar a usar-lo més endavant l'alumnat.

Per ampliar el coneixement de tots aquests conceptes, s'ha de treballar també per part dels nens i les nenes la construcció de fronteres tant en l'espai com en una superfície (utilitzant materials com paper, teles, cartolines, cèrcols, pals, cordes...) i, en aquest últim cas, tant en la realitat com en representacions gràfiques (encerclar els elements d'un conjunt amb un diagrama, per exemple).

Cal treballar també el reconeixement de punts/elements que es troben en la mateixa zona o en una de diferent respecte d'una determinada frontera, en un primer moment en situacions reals i, posteriorment, de manera gràfica. Per exemple, si tenim xiquets i xiquetes dins i fora de l'aula fent diferents activitats, caldrà que a uns els posem al coll un mocador de color roig i als altres de color verd, per diferenciar-los. Si el treball és gràfic, assenyalaran de diferent manera els objectes que hi ha representats dins o fora de la frontera. Per exemple, pintaran de diferent color les vaques que hi ha dins d'un cercat i les que són fora.

Cap al final del cicle, ampliarem aquest treball amb situacions en les quals l'alumnat haja d'utilitzar més d'una frontera en l'espai o en una superfície. Per exemple, en el cas de l'espai, podem estar dins de l'aula però fora de l'armari o posar unes sabates fora de l'armari però dins de la seua caixa. Si ens situem sobre una superfície, es pot xafar dins de la línia del camp de bàsquet però fora de l'àrea de tir 
(figura 184), dibuixar un ocell fora de la casa però dins del requadre, o dins d'un diagrama de conjunts però fora d'un altre. És important que observen les diferents posicions respecte de les fronteres que es consideren i que sàpiguen verbalitzar-les correctament.

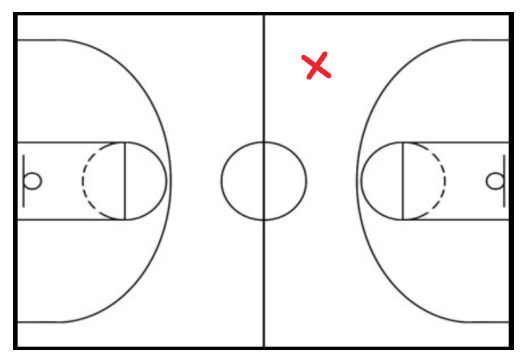

Figura 184. Representació de la posició d'un jugador dins del camp de bàsquet però fora de l'àrea de tir

També en l'últim curs de l'etapa i, com sempre, relacionat amb situacions reals, s'introduirà la frontera en la línia. Cal notar que aquest concepte resulta més complicat que els anteriors. Buscarem situacions en les quals es puga veure clarament que, per a tenir definida una frontera en una línia, necessitem un punt si la línia és oberta i dos si és tancada. Podem utilitzar fileres o rogles formats amb els mateixos xiquets i xiquetes i observar que, per a seleccionar uns quants d'ells sols necessitem un punt de tall en la filera en el primer cas i dos en el rogle, en el segon.

\section{Distingir, construir i representar línies rectes i corbes. Distingir l'horitzontalitat o verticalitat de la línia recta}

Amb aquests nous conceptes que ens ajuden a caracteritzar les línies, amb propietats diferents de les de ser oberta i tancada, entrem dins del camp de la geometria projectiva.

Quan l'alumnat accedeix al 2 n cicle d'educació infantil de ben segur que ha tingut contacte amb línies rectes i corbes en les seues experiències anteriors a l'escola en la realitat $\mathrm{i}$ amb les altres persones. Haurà estat en contacte amb objectes de vores rectes i/o corbes (caixes, pots, fulls, botelles...), haurà escoltat els majors dir d'alguna cosa que és recta o que no, etc.

En aquests moments, encara no podrem treballar de manera específica a l'aula les característiques particulars de les línies rectes i corbes, ni les seues diferències essencials. Sols posarem a l'abast dels xiquets i les xiquetes, perquè els puguen manipular, objectes delimitats tant per línies rectes com per corbes i observarem els traços que fan en les seues produccions gràfiques, per incidir-hi potenciant l'ús equilibrat dels dos tipus de línies (pluja, ones, camins...). El docent anirà utilitzant el vocabulari associat sense esperar necessàriament que ho faça l'alumnat.

Quan estiga un poc avançat el cicle, desenvoluparem activitats que ens aproximen a les idees de línia recta i corba a partir de la realització de fileres de xiquets i xiquetes, 
taules o altres objectes, així com de la seua observació i reflexió sobre les mateixes. Així descobriran que, si miren la filera des d'enfront d'ella i fent coincidir l'altura dels ulls amb el centre del primer element, algunes vegades sols poden veure aquest primer element, mentre que en altres ocasions poden veure diversos elements. La verbalització d'aquestes situacions ens portarà a associar les esmentades fileres amb les idees de línia recta i línia corba, respectivament, i a utilitzar de manera habitual, per part de tots, el vocabulari corresponent per anomenar-les.

A continuació es presenten unes imatges que pretenen escenificar les situacions anteriors, a partir de dues fileres de xiquets i xiquetes (figura 185).
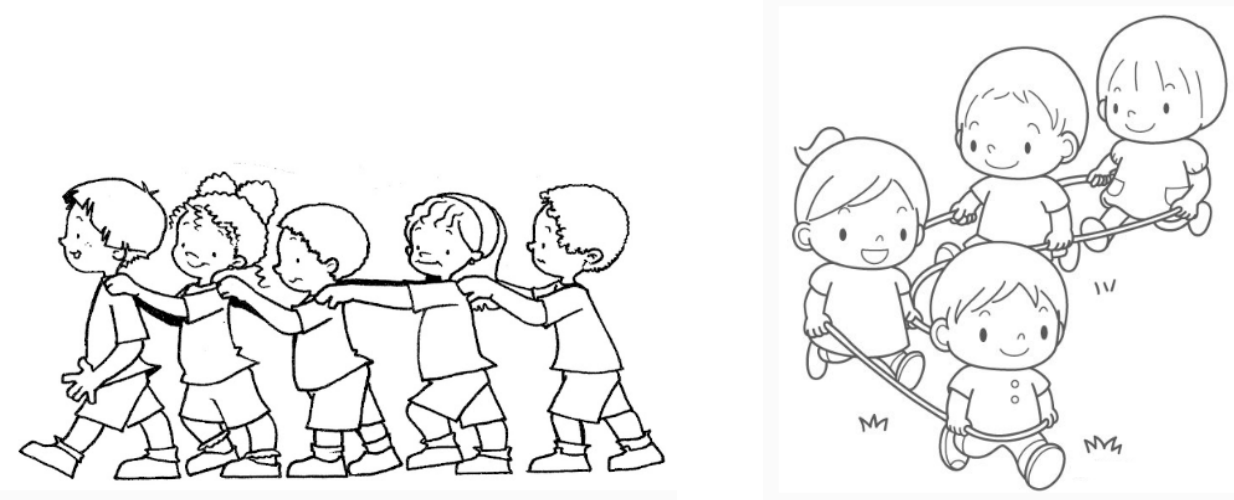

Figura 185. Representació de fileres rectes i corbes de nens i nenes

Ens plantegem què es veuria des de dalt $\mathrm{i}$ ho representem simbòlicament (figura 186).

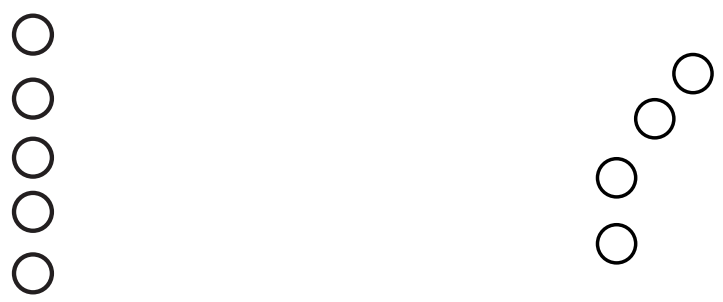

Figura 186. Representació de la vista superior de fileres rectes i corbes

Per tant, des d'una posició situada al davant de la filera, esquemàticament, veuríem el que es representa a la figura 187.
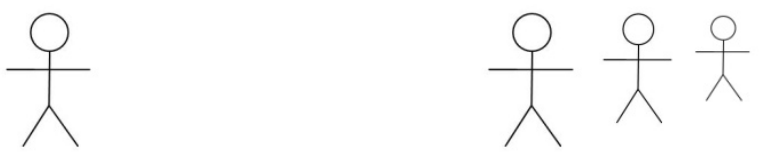

Figura 187. Representació de la vista frontal de fileres rectes i corbes

Com a complement d'aquestes activitats, l'alumnat en realitzarà altres en les quals caminaran per damunt de línies rectes i corbes, o paral·lelament a elles, posant el taló d'un peu junt a la punta de l'altre, observant que a sobre d'un camí recte es 
pot avançar mantenint els peus sempre en la mateixa direcció mentre que, en el cas de la línia corba, és necessari canviar-la girant els peus per poder seguir endavant (figura 188).
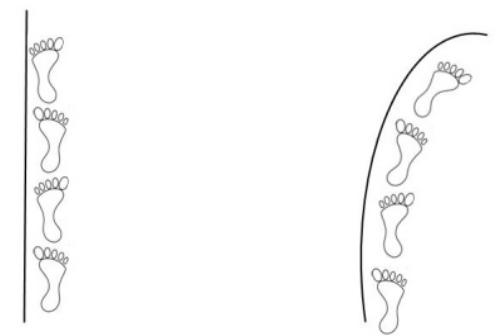

Figura 188. Representació amb petjades d'un recorregut recte (esquerra) i d'un de corb (dreta)

També és convenient treballar la construcció de línies rectes i corbes amb diferents materials (cordes, fils, pals...) i la seua representació gràfica, a partir d'un model si és necessari en un primer moment i sense model més endavant. A més d'altres situacions, és important relacionar aquesta tasca amb activitats reals i gràfiques de camins i laberints com les esmentades en la capacitat 4 d'aquest tema. Observarem sempre que les aproximacions a les línies rectes i corbes que construeixen o dibuixen siguen correctes i les anomenarem adequadament reforçant el vocabulari associat.

En la segona part del cicle i una vegada diferenciades les línies rectes i corbes, prestarem atenció en particular a les primeres, per estudiar les diferents posicions en les quals podem trobar una línia recta. Introduirem aquests conceptes associant-los a les posicions corporals de l'alumnat. Així, un nen «dret» es relacionarà amb una línia vertical i un nena «tombada» amb una d'horitzontal. S'estudiaran també aquestes dues posicions de la línia recta a partir de l'horitzontalitat o verticalitat d'alguns elements de l'entorn: tren, horitzó, farola, arbre, etc., i es completaran amb la idea de línia obliqua, que correspon a qualsevol posició d'una línia recta que no siga vertical ni horitzontal (per exemple, es pot aprofitar l'observació de les posicions que va ocupant un llapis des que es troba dret fins que està totalment recolzat en la taula, com es pot veure en la figura 189).

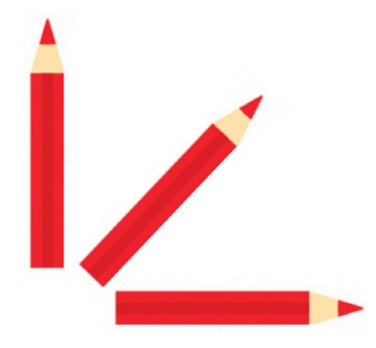

Figura 189. Representació d’un llapis en posició vertical, obliqua i horitzontal

Per anomenar aquestes posicions de la recta introduirem el vocabulari corresponent, que amb el seu ús passarà a formar part del que utilitzen els xiquets i les xiquetes de manera natural. També haurem de treballar el reconeixement de línies 
verticals, horitzontals i obliqües en objectes quotidians: caixes, llibres, joguines, taules, etc., i la seua construcció amb diferents materials: fils, cordes, peces per a muntar trens o torres, etc.

Per portar al paper aquests tipus de línies rectes podem reproduir en fulls grans, que estiguen enganxats a una paret, les siluetes d'alguns alumnes drets i tombats, i també les diferents posicions del llapis esmentat abans. Més endavant seran ells i elles qui les repassen i representen, amb un model si cal.

Cap al final de l'etapa, completarem aquests conceptes associant la posició vertical amb la direcció que va «de dalt a baix» i horitzontal amb la que va «d'un costat a l'altre».

També en el darrer curs és convenient realitzar activitats que els permeten comprovar que la distància més curta entre dos punts és la que es recorre en línia recta. Es pot experimentar amb camins rectes i corbats assenyalats entre dos punts, que l'alumnat recorrerà amb un ritme marcat pel mestre o la mestra i col·locant els peus en línia continua per a observar que hi arriba primer el xiquet o xiqueta que camina per l'itinerari recte.

\section{Experimentar la intersecció de línies. Reconèixer nusos i xarxes}

En aquesta capacitat ampliem l'estudi de les línies amb la consideració de diverses a la vegada, en lloc de treballar-les de manera aïllada com hem fet fins ara.

En aquest context, s'anomena nus a qualsevol punt que pertany a més d'una línia, en el cas que siga simple, o a la mateixa línia si no ho és (figura 190). Inevitablement hi ha un concepte associat, el de xarxa que és un conjunt de línies connectades per diversos nusos.
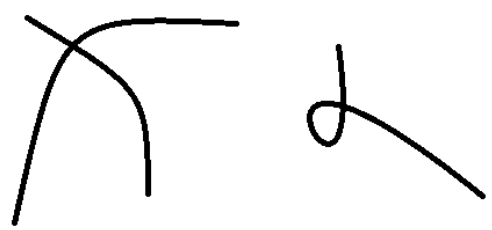

Figura 190. Representació de nusos determinats per dues línies simples (esquerra) i per una no simple (dreta)

En la segona meitat del cicle caldrà fer un reconeixement de nusos a partir dels desplaçaments de l'alumnat per diferents camins que tinguen punts en comú: intersecció de passadissos, de carrers, camins o carreteres, i treballar també la construcció d'itineraris amb nusos i la representació gràfica de camins que els continguen i que, per tant, formen xarxes.

Per últim, realitzarem activitats gràfiques de representació de nusos i xarxes, que poden ser reflex d'alguna situació que hagen viscut en la realitat o ser un recorregut inventat directament a partir d'un plànol, mapa, etc. (figura 191). 


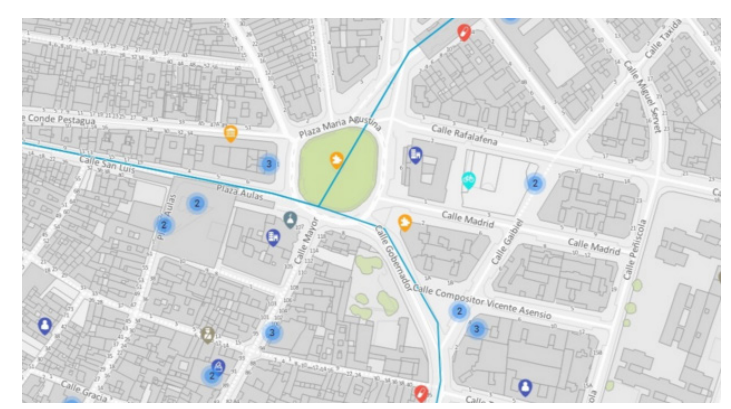

Figura 191. Representació d'un plànol de la ciutat de Castelló amb un recorregut assenyalat

El docent utilitzarà el vocabulari específic associat a aquests conceptes, però no es treballa amb la intenció que l'usen els xiquets i les xiquetes.

Relacionat amb la presència de nusos entre les línies, es pot desenvolupar l'aprenentatge per part de l'alumnat de la tasca de «cordar-se» els cordons de les sabates.

Nota: Quan entre dues línies rectes situades en el mateix pla no hi ha cap punt de contacte, ens trobem en presència de línies paral·leles. El concepte de paral·lelisme resulta complicat per als xiquets i les xiquetes, ja que està associat al concepte d'infinit i exigeix sempre que pensen en la prolongació de les línies que estan observant $i$ aventuren si es tallaran o no més enllà del que es veu. Per aquestes raons, el paral·lelisme no s'estudia en educació infantil, on les línies que es treballen sempre es troben.

\section{Distingir i construir superficies planes $i$ corbes}

Començarem aquest treball en l'últim curs de l'etapa mitjançant activitats de contacte directe amb diferents superfícies planes i corbes, observant les diferents sensacions que els xiquets i les xiquetes perceben en tocar, asseure's, recolzar-se o recolzar altres objectes damunt d'una caixa gran, del terra, d'una pilota, d'un tub cilíndric, etc. Aquests contactes i observacions generen idees intuïtives del que són superfícies planes i superfícies corbes, que es complementen amb la introducció del vocabulari adient per anomenar-les.

Es treballarà també el reconeixement de superfícies planes i corbes en objectes de l'entorn i la construcció d'aquests dos tipus de superfícies amb teles, papers, cartolines, etc.

Com hem comentat en algunes capacitats anteriors, l'alumnat d'aquesta etapa no pot desenvolupar adequadament la representació gràfica de superfícies, pel que continuarem deixant-los dibuixar sense esperar fidelitat i correcció en les seues produccions.

Sols al final de l'etapa es pot intentar que alguns arriben a captar la diferència geomètrica essencial entre les superfícies planes i corbes adonant-se que a sobre de 
les planes es poden dibuixar línies rectes en qualsevol direcció mentre que, en el cas de les corbes, hi ha direccions en les quals no s'hi pot fer.

\section{Reconèixer, nomenar, construir i representar les figures geomètriques planes: cercle, triangle, quadrat i rectangle}

Les qüestions relacionades amb les formes geomètriques que anem a treballar en aquesta capacitat, ens mantenen dins dels conceptes que formen part de la geometria de les projeccions, però ara referits a les transformacions geomètriques anomenades semblances.

Iniciarem el coneixement de les figures planes introduint el cercle al principi del $2 n$ cicle d'educació infantil. L'alumnat observarà i manipularà objectes reals la característica dels quals siga que roden, experimentant amb ells aquesta possibilitat de moviment (monedes, galetes, pots, pilotes, etc.). A continuació els els farem tocar perquè reconeguen la superfície plana i de perfil arrodonit que tenen alguns d'ells i traslladaran el seu contorn, per exemple, al terra o a un paper pla, envoltant-la amb un llapis i observant que sempre queda marcada una línia tancada de la mateixa forma, una circumferència. Com les figures que treballem són superfícies planes i no línies, hauran d'acolorir la zona limitada per la circumferència i introduirem el concepte de cercle com la porció de pla que han acolorit (figura 192), així com el seu nom, que utilitzarem de manera habitual.
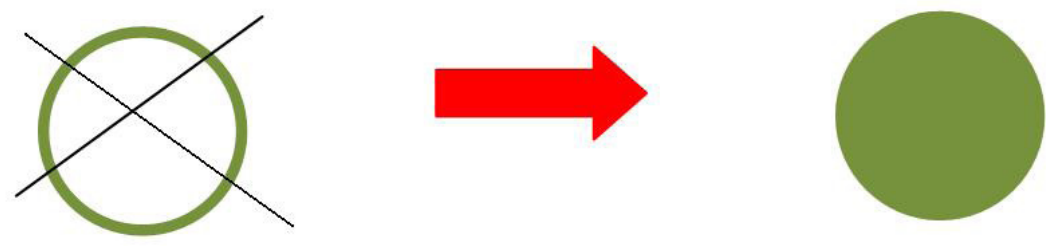

Figura 192. Representació d'una circumferència i d'un cercle

Després de conèixer el cercle, observaran i manipularan objectes que no roden (porcions i caixes de formatge, caixes d'alguns xocolates, caixes de xarop, gomes d'esborrar, daus...) per descobrir-hi la presència de «cantons o puntes» $\mathrm{i}$ de vores rectes en compte de corbes. Amb el trasllat al paper dels contorns de les cares d'alguns d'aquests objectes i després d'haver acolorit els seu interior, establirem diferències entre les figures obtingudes (tres o quatre «ratlles», tres o quatre «puntes») $\mathrm{i}$ introduirem en el vocabulari habitual de l'aula els noms triangle i quadrat per a referir-nos-en respectivament (no utilitzarem les paraules costat i vèrtex).

L'observació, manipulació i experimentació amb materials didàctics específics per part dels xiquets i les xiquetes els permetran visualitzar adequadament les figures que hem introduït i estudiar les seues semblances i diferències (vegeu figura 193). A més, insistirem en el reconeixement de cercles, triangles i quadrats en objectes quotidians reals. Tant en un cas com en l'altre i amb la finalitat d'enriquir el concepte de triangle, hem de posar a l'abast de l'alumnat triangles de diferents tipus, 
evitant la presència quasi permanent dels equilàters i l'absència, moltes vegades, dels isòsceles i dels escalens.

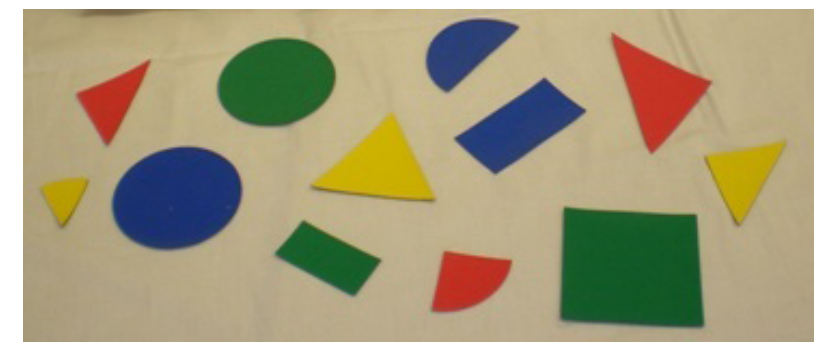

Figura 193. Figures geomètriques planes (Geometric shapes, fabricat per Ness Arnold Ltd.)

Cap a la meitat del cicle podem ampliar el treball amb aquestes figures desenvolupant activitats per a construir-les (per exemple, amb fils, pals, cordes, furgadents, gomes elàstiques, llistons, etc.) relacionades amb situacions d'aula que les necessiten (jocs, murals, exposicions de treballs, etc.). En la realització d'aquestes activitats ha de quedar clar que la figura plana és el tros de paper (de superfície plana) que està limitat pel contorn i no el contorn a soles, cosa que afavorirem retallant les figures (figura 194).
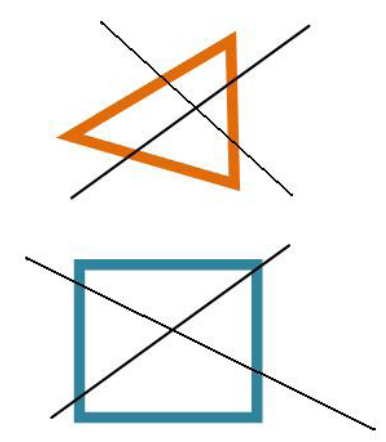
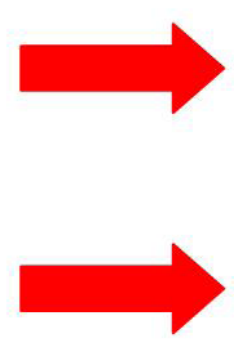
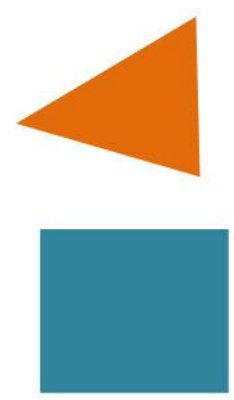

Figura 194. Representació del contorn d'un triangle i un quadrat i de les figures corresponents

També associat amb algunes situacions d'aula, caldrà treballar la representació gràfica de les figures per part dels xiquets i les xiquetes tenint en compte les seues limitacions a l'hora de fer-ho. En principi, acceptarem com a cercle qualsevol representació d'una superfície limitada per una línia corba tancada que ells reconeguen així. Per tal de representar els vèrtex de les altres figures evitant que els puguen eixir arrodonits, cal orientar-los i aconsellar-los que facen un segment recte per a cada costat, alçant el llapis del paper quan arriben a l'extrem i hagen de canviar de direcció per a continuar amb el dibuix. És a dir, cal fer el contorn del triangle (quadrat) en tres (quatre) traços separant el llapis del paper en haver acabat cadascun d'ells.

Aprofitarem totes les activitats anteriors per a insistir en les semblances i diferències que hi ha entre les figures treballades: el cercle no té vèrtex ni línies rectes, el triangle i el quadrat sí que en tenen, però el primer sols té tres puntes i tres ratlles, mentre que el segon en té quatre de cada. 
El rectangle s'introduirà de manera similar a les figures anteriors, manipulant objectes que el continguen en la seua frontera (per exemple, les cares laterals d'una caixa, d'un frigorífic...) traslladant al pla el contorn d'alguna de les cares corresponents i acolorint-ne la zona interior. En un principi l'alumnat pot confondre'l amb el quadrat ja conegut. Per a evitar-ho i, recolzant-nos en la classificació excloent dels quadrilàters, caldrà marcar clarament la diferència: el quadrat té els quatre costats de la mateixa longitud i el rectangle en té dos iguals que són més llargs que els altres dos, que també són iguals. Aquesta referència a diferents longituds, ens introdueix en la geometria mètrica.

En reomplir la superfície interior dels contorns representats, cal recordar que, de manera anàloga a les altres figures planes, el rectangle és la porció del pla delimitada pel contorn, i no el contorn a soles. Per anomenar aquestes noves figures introduirem la paraula rectangle que vindrà a completar el vocabulari corresponent a aquesta capacitat.

Per afavorir el coneixement d'aquesta nova figura es realitzaran activitats de manipulació de materials didàctics que continguen rectangles i del seu reconeixement en objectes reals, aprofitant-les per a insistir en les semblances i diferències entre les figures anteriors i aquesta.

També hauran de construir rectangles amb diferents materials i de representar-los quan siga necessari per a desenvolupar alguna tasca de l'aula, sense oblidar la necessitat de reomplir l'interior del contorn de la figura i deixant molt clares les diferències amb els quadrats.

Amb el treball d'aquesta capacitat hem fet els primers passos cap al coneixement més ampli i profund de les figures planes que es desenvoluparà en educació primària.

\section{Reconèixer i nomenar els cossos geomètrics: cub i esfera}

En la capacitat 6 hem parlat de l'espai geomètric «complet» que habitualment és l'espai general i de l'espai geomètric «particular», l'ocupat per un cos. Dedicarem atenció ara als cossos més senzills com a complement del treball realitzat en la capacitat anterior amb les figures planes.

Al llarg de tot el cicle, l'alumnat ha pres contacte amb molts objectes dels seu entorn, però sense parar-hi atenció com a cossos geomètrics.

En el darrer curs de l'etapa, manipularan i observaran objectes/cossos reals considerant-los com a elements que ocupen una part de l'espai (pilotes, taronges, daus, pots...) i diferenciant uns dels altres en funció de l'existència de superfícies planes o corbes en les fronteres que els delimiten. De manera anàloga a les figures planes, hem d'insistir en el fet que el cos és l'espai que es troba limitat per la frontera i no sols la superfície exterior que podem tocar amb les mans. 
Prestarem especial atenció als cubs i les esferes, introduint els seus noms i utilitzant-los correctament quan siga necessari. És important manipular materials didàctics específics que els permeten visualitzar correctament els cossos treballats (figura 195), a més de construir-los amb materials compactes (plastilina o fang, per exemple) i observar el seu interior tallant-los per descobrir que estan plens i no buits per dins. Si es treballa la construcció d'aquests cossos amb materials no compactes com tubs rígids o flexibles, fils d'aram, etc., és necessari insistir també en la idea de cos com tota la porció d'espai limitada per la frontera.

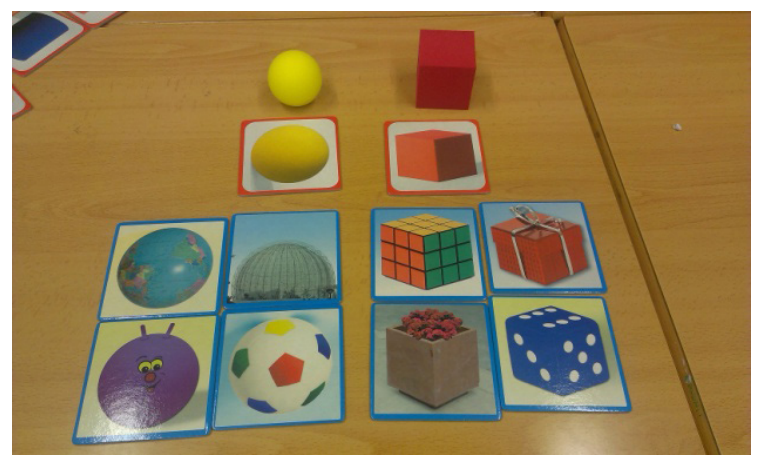

Figura 195. Figures Geomètriques en l'entorn (fabricat per Akros)

\section{Compondre i descompondre figures i cossos geomètrics}

Cap a la meitat del 2 n cicle d'educació infantil, ampliarem el coneixement de les figures planes i dels cossos geomètrics amb activitats de la seua composició i descomposició, que en general estaran relacionades amb situacions d'aula en les quals siga necessari fer-les (per exemple, muntar una figura a partir de les seues parts, completar un mosaic, un dibuix, etc.).

Podem començar component i descomponent qualsevol de les figures no circulars a partir de diferents tipus de triangles i continuar combinant totes aquestes figures per obtenir també alguna d'elles. Cal que observen com es combinen unes figures per a formar-ne d'altres i quines condicions han d'acomplir les figures inicials per poder obtenir una determinada. Per exemple, quan es pot compondre o descompondre un rectangle amb dos quadrats, un quadrat amb dos triangles iguals, o un rectangle amb dos quadrats o dos triangles, etc. (figura 196).
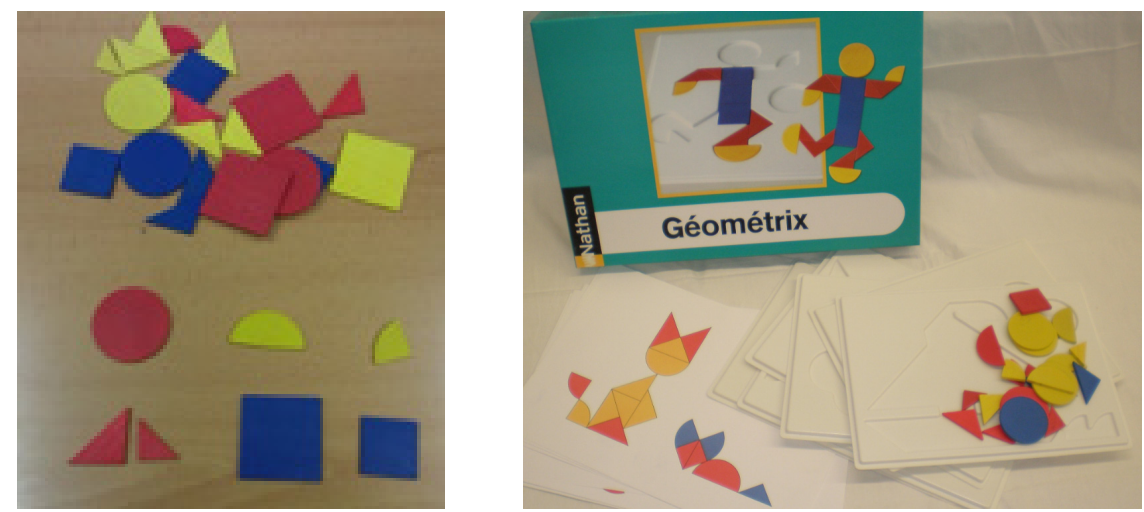

Figura 196: Géométrix (fabricat per Nathan) 
Amb el cercle farem un treball semblant, component-lo i descomponent-lo a partir de semicercles, quadrants de cercle, sectors o segments circulars i reflexionant també sobre les condicions de les figures inicials per poder compondre un cercle.

Totes les activitats comentades per a les figures planes es desenvoluparan al principi utilitzant materials formats per peces que puguen acoblar-se i, més endavant, mitjançant representacions gràfiques.

Per últim, i cap al final de l'etapa, es poden compondre i descompondre també cubs i esferes a partir de diferents fragments seus (ortòedres, semiesferes...). Evidentment, aquest treball es realitzarà sols de manera manipulativa $\mathrm{i}$ amb menys profunditat que el corresponent a les figures planes.

\section{Iniciar la idea de simetria en el propi cos, en figures planes i en cossos qualssevol}

Aquesta capacitat complementa el treball referent a les posicions espacials «a la dreta», «a l'esquerra» que hem vist en les primeres capacitats del tema i pretén que els xiquets $i$ les xiquetes puguen observar i reflexionar al voltant d'algunes figures o cossos que presenten dos costats que es desenvolupen igual en referència a un determinat eix o pla.

Es comença a treballar en l'últim curs, observant l'alumnat el seu propi cos i arribant a visualitzar un eix o un pla a partir del qual el cos es desenvolupa en dues parts iguals. Això mateix cal reconèixer-lo en alguns objectes de la realitat (fruites, construccions...) i en altres elements de la mateixa aula: lletres majúscules, nombres, figures geomètriques, etc., que treballaran de manera manipulativa i també amb representacions gràfiques (figura 197).
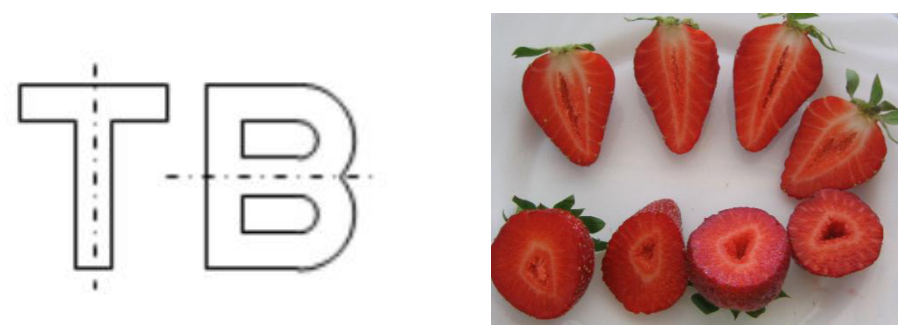

Figura 197. Representació d'imatges simètriques en objectes i figures planes

En una figura simètrica, a partir de l'eix de simetria, la figura no és igual sinó que es desenvolupa d'igual manera a cada costat d'aquest (vegeu 3.2.3.2, d'aquest tema). Si la figura es doblega per l'esmentat eix, el contorn i l'interior de les dues meitats coincideixen. Si les dues parts de la figura foren iguals als dos costats de l'eix, en doblegar-la per aquest eix, les parts no coincidirien.

Com a complement es poden realitzar activitats amb un calidoscopi perquè l'alumnat observe la simetria de les figures que s'hi creen i també deixar caure pintura 
sobre un paper i doblegar-lo després per comprovar en desplegar-lo que s'ha format una figura simètrica respecte del plec del paper.

Podem treballar amb jocs de peces en els quals cal compondre figures simètriques a partir de les seues meitats homòlogues i amb d'altres en els quals es desenvolupa la construcció de figures simètriques utilitzant alguns materials didàctics que permeten disposicions simètriques de peces o fitxes per a formar figures que també ho siguen (figura 198).
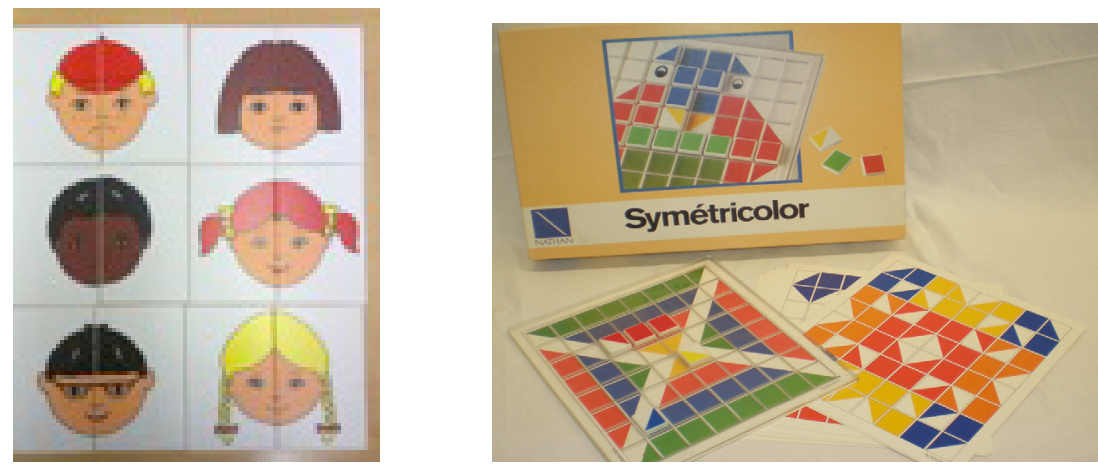

Figura 198. Caras en simetría (fabricat per HenBea, esquerra) i Symétricolor (fabricat per Nathan, dreta)

També podem intentar que completen gràficament una figura simètrica molt senzi1la, donant-los una sola meitat sobre una quadrícula i, si és necessari, amb l'ajuda d'un espill, visualitzar la figura completa abans de dibuixar-la (figura 199).

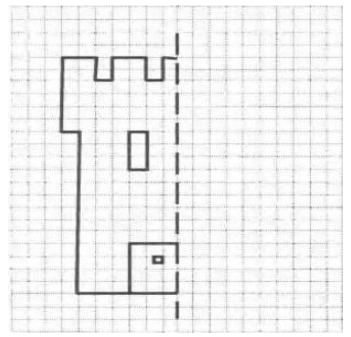

Figura 199. Representació en una quadrícula de la meitat d'una imatge simètrica

Treballar la simetria és una tasca difícil i el que es fa en educació infantil és sols una petita aproximació a les primeres idees sobre aquest concepte, que es desenvolupa amb més extensió i profunditat en educació primària.

16. Organitzar trencaclosques, puzles, sanefes, etc.

En aquesta capacitat es reprenen i reforcen molts dels aspectes topològics i geomètrics que hem treballat fins ara. Per a desenvolupar-la es fa necessari aclarir alguns dels termes que apareixen en el seu enunciat.

Així, parlarem de trencaclosques quan les peces que els componen tinguen les vores definides per línies rectes o corbes molt senzilles i de puzles quan les tinguen 
determinades per línies corbes més complexes que canvien diverses vegades de curvatura.

Es desenvolupa al llarg de tot el $2 \mathrm{n}$ cicle i es pretén que l'alumnat combine la part geomètrica amb la part artística per realitzar les activitats corresponents, que en alguns casos pretenen recobrir el pla i en d'altres sols una part.

Començarem per la resolució de trencaclosques senzills amb poques peces i, a poc a poc, augmentarem la seua dificultat fent créixer el seu nombre. Més endavant incorporarem el treball amb puzles seguint un procés anàleg a l'anterior per arribar al final de l'etapa amb un desenvolupament prou avançat de les possibilitats de l'alumnat en aquest tipus d'activitats.

En alguns dels materials que es poden utilitzar per a desenvolupar aquest treball, els proporcionem figures la forma de les quals és una composició de diferents formes geomètriques perquè tracten de compondre-la (figura 200).

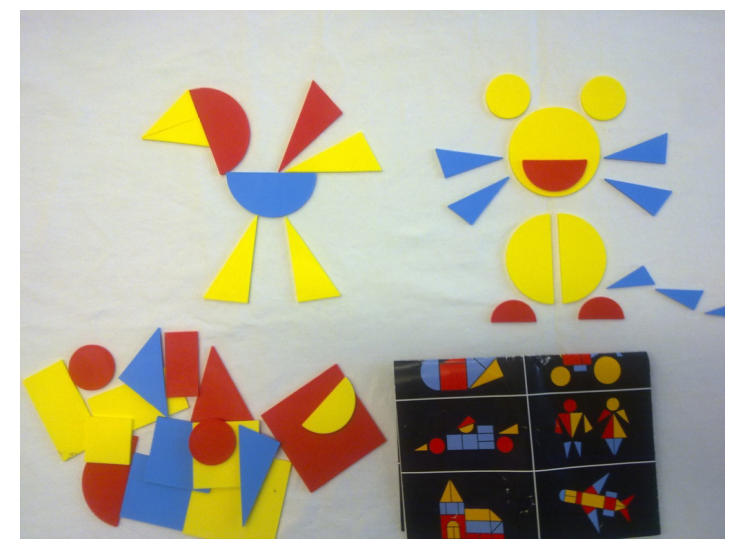

Figura 200. Mosaic Múltiple (Playshapes, fabricat per Invicta Plastics Ltd.)

En aquesta línia de treball hi ha un material molt conegut, el Tangram, amb el qual podem potenciar l'habilitat d'imaginar composicions i descomposicions de figures, al nivell corresponent a l'etapa d'infantil, en el qual s'indicarà sempre a l'alumnat els contorns dels fragments que componen la imatge (figura 201).
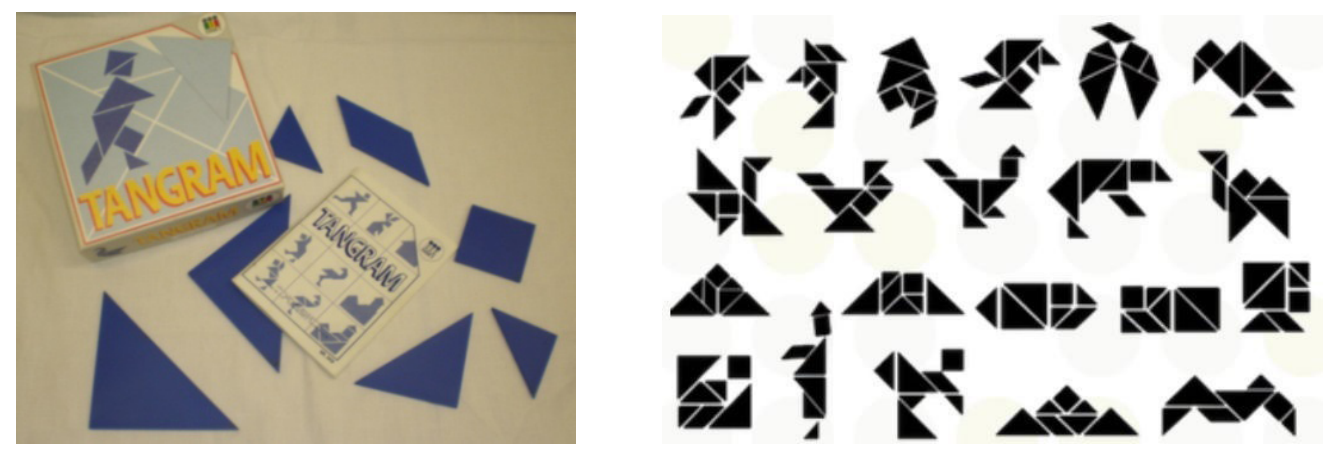

Figura 201. Tangram (fabricat per Diset, esquerra) i algunes imatges fragmentades per compondre-les (dreta) 
També es treballarà en la segona part del cicle amb la composició de sanefes, tant amb peces reals com en representacions gràfiques. En aquest sentit, al principi es poden realitzar activitats en les quals només hagen d'acolorir sanefes que ja estan dibuixades i, més endavant, se'ls demanarà que dibuixen, a partir d'un model inicial, els fragments que componen la sanefa a més d'acolorir-les després (figura 202).
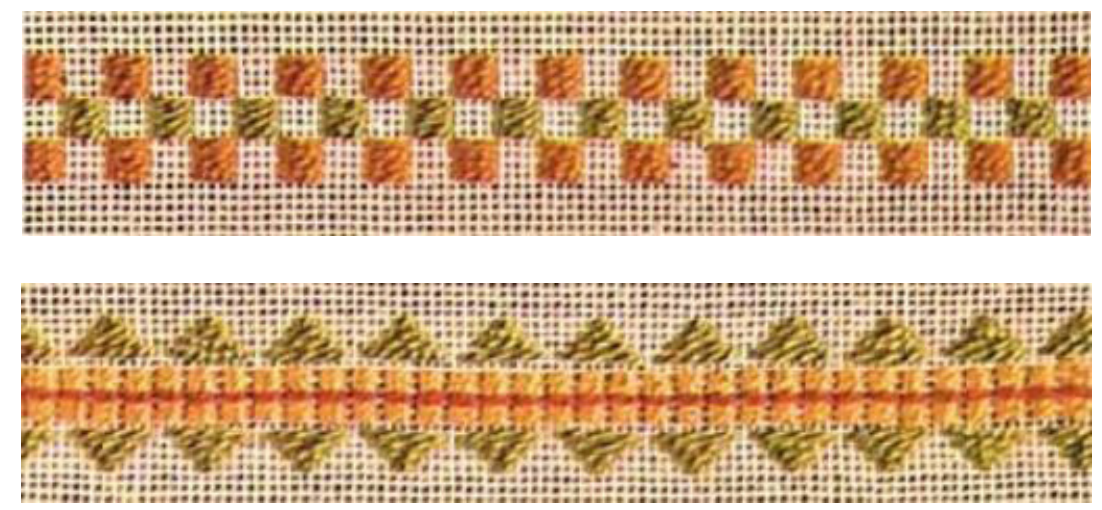

Figura 202. Representació de dues sanefes 


\section{Referències Bibliogràfiques}

Alsina, A. (2004): Com desenvolupar el pensament matemàtic, Vic, Eumo Editorial.

- (2011a): Educación matemática en contexto de 3 a 6 años, Barcelona, ICEHorsori.

— (2011b): Aprendre a usar les matemàtiques, Vic, Eumo Editorial.

Argüelles, J. (1989): Historia de la Matemática, Torrejón de Ardoz, Madrid, Akal.

Bishop, A. J. (1999): Enculturación matemática. La educación matemática desde una perspectiva cultural, Barcelona, Paidós.

Dorce, C. (2013): Història de la Matemàtica. Des de Mesopotàmia al renaixement, Barcelona, Publicacions i Edicions de la Universitat de Barcelona.

- (2014): Història de la Matemàtica. Des del segle XVII fins a l'inici de l'època contemporània, Barcelona, Publicacions i Edicions de la Universitat de Barcelona.

Gallego, C. et al. (2005): Repensar el aprendizaje de las matemáticas. Matemáticas para convivir comprendiendo el mundo, Barcelona, Graó.

IfrAH, G. (2001): Historia universal de las cifras. La inteligencia de la humanidad contada por los números y el cálculo, Espasa Calpe, Madrid.

- (1988): Las cifras. Historia de una gran invención, Madrid, Alianza Editorial.

Kноте, S. (1982): Cómo utilizar los bloques de Z. P. Dienes, Barcelona, Teide.

Pérez, I.; Alcalde, M.; Lorenzo, G. (2014): Els nombres enters i racionals, les magnituds i la mesura a l'aula de primària. Col·lecció Sapientia, núm. 96, Castelló, Publicacions de la Universitat Jaume I. http://hdl.handle.net/10234/108098

Piaget, J.; Inhelder, B. (1984): Psicología del niño, Madrid, Morata.

Santos, C. (coord.) (1992): Los Bloques Lógicos de Dienes en Educación Infantil y Primaria, Salamanca, Amarú Ediciones.

Segovia, I.; Rico, L. (coords.) (2011): Matemáticas para maestros de Educación Primaria, Madrid, Pirámide.

Stewart, I. (2008): Historia de las matemáticas en los últimos 10.000 años, Barcelona, Crítica.

Vygotsky, L. S. (1989): Desarrollo de los procesos psicológicos superiores, Barcelona, Crítica.

\section{Bibliografía recomanada}

Alcalde, M.; Pérez, I.; Lorenzo, G. (2014): Els nombres naturals a l'aula de Primària. Col·lecció Sapientia, núm. 89. Publicacions de la Universitat Jaume I. Castelló. http://hdl.handle.net/10234/81388.

Algás, P. et al. (2010): Los proyectos de trabajo en el aula. Reflexiones y experiencias prácticas, Barcelona, Graó.

Alsina, C. et al. (1995): Ensenyar matemàtiques, Barcelona, Graó.

Balaux, A. (2003): Manual de matemàtiques del professor de primària, Barcelona, Edicions de la Universitat de Barcelona. 
Berdoneau, C. (2008): Matemáticas activas (2-6 años), Barcelona, Graó.

CAlvo, X. et al. (2002). La geometría: de las ideas del espacio al espacio de las ideas en el aula. Claves para la innovación educativa, 17, Barcelona, Graó.

Canals, M. A. (2000): Viure les matemàtiques de 3 a 6 anys, Barcelona, Rosa Sensat.

- (2009a): Lògica a totes les edats, Barcelona, Rosa Sensat.

- (2009b): Primers nombres i primeres operacions, Barcelona, Rosa Sensat.

- (2009c): Transformacions geomètriques, Barcelona, Rosa Sensat.

- (2009d): Superfícies, volums i línies, Barcelona, Rosa Sensat.

- (2010): Problemes i més problemes, Barcelona, Rosa Sensat.

CArbó, L.; Gràcia, V. (2.002): Mirant el món a través dels números, Lleida, Pagés Editors, S. L.

Chamorro, M. C. (2005): Didáctica de las Matemáticas para la Educación Infantil, Madrid, Pearson Prentice Hall.

Chamoso, J. et al. (2013): Las matemàticas en las primeras edades escolares, Tres Cantos (Madrid), Nívola.

Chevallard, Y. et al. (1997): Estudiar matemáticas. El eslabón perdido entre enseñanza y aprendizaje, Barcelona, ICE Univ. Barcelona - Ed. Horsori.

Fernández, J. A. (2000): Didáctica de la Matemática en la Educación Infantil, Madrid, Ediciones Pedagógicas.

Flores, P. et al. (2011): Materiales y recursos en el aula de matemáticas, Granada, Universidad de Granada. http://digibug.ugr.es/bitstream/10481/21964/1/ libro_MATREC_2011.pdf

Godino, J. (dir. i ed.) (2003-2004): Matemáticas y su Didáctica para maestros. Proyecto Edumat-Maestros, Granada, Universidad de Granada.

http://www.ugr.es/local/jgodino/edumat-maestros/

Lorenzo, G.; Alcalde, M.; Pérez, I. (2015): La geometria i l'estadística en l'aula de. Primària, Col·lecció Sapientia, núm. 110, Castelló, Publicacions de la Universitat Jaume I, http://hdl.handle.net/10234/108118.

Ruesga, M. P. (2005): El inicio del razonamiento en la infancia, Burgos, Editoriales Universitarias Españolas, Universidad de Burgos.

StEEn, L. A. (ed.) (1.998): Las Matemáticas en la vida cotidiana, Madrid, Addison-Wesley Iberoamericana - Universidad Autónoma de Madrid. 


\section{Índex de figures}

Figura 1. Representació de conjunts. diagrama lineal (esquerra), de Venn (centre) i un altre de línia tancada (dreta)

Figura 2. Representació de la unió dels conjunts A i B

Figura 3. Representació de la unió dels conjunts $\mathrm{C}$ i B

Figura 4. Representació de la intersecció dels conjunts A i B

Figura 5. Imatge dels blocs lògics de Dienes.

Figura 6. Representació d'una correspondència unívoca

Figura 7. Representació d'una correspondència biunívoca

Figura 8. Representació d'una aplicació.....

Figura 9. Representació d'una aplicació bijectiva

Figura 10. Imatges d'objectes per a treballar cercles, quadrats i triangles ..

Figura 11. Imatge d'un material didàctic d'encaixos.

Figura 12. Representació d'un exemple d'error de contaminació

Figura 13. Representació d'un conjunt determinat per una característica negativa

Figura 14. Representació d'un conjunt de cercles i d'un altre que no ho són

Figura 15. Representació d'un exemple per a il·lustrar l'error de limitació

Figura 16. Representació amb creus de la selecció dels elements d'un conjunt

Figura 17. Representació amb diagrama individual de la selecció dels elements d'un conjunt

Figura 18. Representació amb un únic diagrama dels elements d'un conjunt

Figura 19. Representació del subconjunt de triangles dins de les peces grans dels blocs lògics

Figura 20. Classificació d'alguns blocs lògics pel color (equerra); formació del conjunt de peces roges (dreta)

Figura 21. Classificació dels mitjans de transport pel tipus de vehicle (esquerra); formació del conjunt d'avions (dreta).

Figura 22. Classificacions d'algunes peces dels blocs lògics: segons el color (esquerra); la forma (centre) i la gròssària (dreta)

Figura 23. Representació del mòdul de quatre elements diferents d'una sèrie

Figura 24. Representació del mòdul de cinc elements d'una sèrie amb tres canvis de característica.

Figura 25. Representació del mòdul de sis elements d'una sèrie amb tres canvis de característica

Figura 26. Representació de dos mòduls, de tres elements diferents per una característica, d'una sèrie

Figura 27. Representació dels cinc elements del mòdul d'una sèrie amb un canvi d'una característica .

Figura 28. Ritmo (fabricat per Nathan) 
Figura 29. Representació d'un mòdul de vuit elements d'una sèrie amb tres canvis d'una característica

Figura 30. Representació d'un mòdul de tres elements d'una sèrie amb dos canvis de dues característiques

Figura 31. Representació d'un mòdul de cinc elements d'una sèrie amb un canvi de dues característiques ....

Figura 32. Pyramide 3 en 1, fabricat per Small Foot Company (esquerra) i Decreixent tractors, fabricat per Willis Toys Ltd (dreta)

Figura 33. Representació d'una correspondència entre taules col·lectives i grups de treball.

Figura 34. Representació d'una correspondència de transformació amb blocs lògics.

Figura 35. Representació d'una classificació amb diagrames

Figura 36. Representació d'una ordenació amb fletxes (esquerra) i amb nombres (dreta)

Figura 37. Representació d'una correspondència que associa parelles d'animals iguals

Figura 38. Anelles de colors (fabricat per Goula)

Figura 39. Ús d'anelles de colors sols amb punts (esquerra) i amb punts i xifres (dreta)

Figura 40. Peces del material Aprenc a comptar (fabricat per Lado)

Figura 41. Seqüència de la construcció del nombre 6 (d'esquerra a dreta).

Figura 42. Varetes associades als nombres per la seua altura (esquerra) i ús de la vareta del 6 amb peces del 2 (dreta).

Figura 43. Representació d'una aplicació bijectiva entre dos conjunts finits.

Figura 44. Símbols en l'escriptura jeroglífica egípcia (Ifrah, 1988)

Figura 45. Escriptura jeroglífica del nombre 2.425 (Ifrah, 1988)....

Figura 46. Representacions numèriques en l'escriptura acrofònica grega (Ifrah, 1988)

Figura 47. Escriptura acrofònica del nombre 7.699 (Ifrah, 1988)

Figura 48. Numeració alfabètica grega (Ifrah, 1988)

Figura 49. Numeració romana

Figura 50. Xifres àrabs (Ifrah, 1988)

Figura 51. Evolució de les xifres àrabs a Europa (Ifrah, 1988)

Figura 52. Gravat del començament del segle XVI que representa el triomf dels algorismes sobre els àbacs. Els algoristes, emprant les nou xifres i el zero, s’imposen als abaquistes, ja que són capaços de fer més ràpidament les operacions aritmètiques. En segon pla, la dama Aritmètica, amb un vestit guarnit de xifres, mostra amb la mirada quines són les seues preferències (Ifrah, 1988).

Figura 53. Representació de pocs núvols i moltes estrelles

Figura 54. Representació d'animals de granja amb poques vaques i molts cavalls.

Figura 55. Representació d'una correspondència biunívoca entre el conjunt de cavalls i el de vaques 
Figura 56. Representació de les siluetes de 1'1, el 2 i el 3

Figura 57. Imatges d'Egipte per a comptar persones (esquerra) i piràmides (dreta)

Figura 58. Representació d'una taula amb 5 plats i d'una altra amb gots i culleres

Figura 59. Representació d'una taula amb conjunts equipotents de plats, gots i culleres.

Figura 60. Classificació d'envasos per a 6,10 o 12 ous

Figura 61. Exemple de material gràfic per a treballar la classificació pel cardinal

Figura 62. Representació d'un conjunt amb tres coets espacials i d'un altre amb nou planetes dibuixats per l'alumnat.

Figura 63. Representació de cinc taronges retallades d'un catàleg i la seua distribució en dos murals

Figura 64. Imatge d'una tenda escolar.

Figura 65. Representació del càlcul manipulatiu i numèric del preu

d'una compra de dos productes

Figura 66. Representació del càlcul manipulatiu i numèric dels diners que els queden després de fer una compra

Figura 67. Representació d'un xiquet en posició de balança sospesant unes fruites

Figura 68. Representació d'una balança (fabricada per Osmiroid)

Figura 69. Representació d'alguns edificis d'una ciutat....

Figura 70. Representació de gots amb diferents quantitats d'aigua (tots dos de l'esquerra) i amb la mateixa quantitat (tots dos de la dreta)........

Figura 71. Representació del càlcul experimental de la mesura de les longituds d'una taula i una porta amb diversos peus iguals

Figura 72. Representació del càlcul experimental de la mesura de la longitud d'una taula mitjançant el transport d'una sola unitat fent marques

Figura 73. Representació del càlcul experimental de la mesura de la longitud d'una taula comptabilitzant el transport d'una sola unitat de longitud ...

Figura 74. Representació del càlcul experimental de la mesura de la capacitat de dos gerros amb diversos gots iguals

Figura 75. Calendari magnètic (fabricat per HenBea)

Figura 76. Seqüències temporals Zaro i Nita (fabricat per Akros)

Figura 77. Representació del càlcul experimental del pas del temps amb espelmes: situació inicial (esquerra) i final (dreta).

Figura 78. Rellotge d'engranatges (fabricat per Kalmarsund).

Figura 79. Calendari escolar (fabricat per Akros).

Figura 80. Exemples de transformacions topològiques

Figura 81. Exemples de projeccions

Figura 82. Exemples de transformacions afins

Figura 83. Exemples de semblances

Figura 84. Exemples d'un gir i una simetria axial en figures planes

Figura 85. Representació dels eixos de coordenades amb la situació de dos punts....

Figura 86. Representació vectorial d'una recta. 
Figura 87. Representació de rectes secants en el pla

Figura 88. Representació de rectes paral·leles no coincidents

Figura 89. Representació de rectes paral leles coincidents

Figura 90. Representació de rectes que es creuen en l'espai

Figura 91. Representació d'una circumferència i d'un dels seus radis....

Figura 92. Representació de les posicions relatives d'una circumferència i una recta en el pla.

Figura 93. Representació d'una superfície plana convexa

Figura 94. Representació d'una superfície plana còncava

Figura 95. Representació d'una regió angular

Figura 96. Representació d'una línia poligonal simple

Figura 97. Representació d'una línia poligonal no simple

Figura 98. Representació d'un angle interior d'un polígon

Figura 99. Representació d'un triangle acutangle

Figura 100. Representació d'un triangle rectangle

Figura 101. Representació d'un triangle obtusangle.

Figura 102. Representació d'un triangle equilàter.

Figura 103. Representació de dos triangles isòsceles

Figura 104. Representació d'un triangle escalè....

Figura 105. Representació d'un quadrat

Figura 106. Representació d'un rectangle

Figura 107. Representació d'un rombe

Figura 108. Representació d'un romboide

Figura 109. Representació d'un trapezi isòsceles

Figura 110. Representació d'un trapezi escalè

Figura 111. Representació d'un trapezi rectangle.

Figura 112. Representació d'un trapezoide.

Figura 113. Representació de pentàgons: regular convex (esquerra), irregular convex (centre) i irregular còncau (dreta)

Figura 114. Representació d'un pentacle

Figura 115. Representació de l'esbós i del quadre Leda atòmica de Dalí, 1949.

Figura 116. Representació d'hexàgons: regular convex (esquerra), irregular convex (centre) $\mathrm{i}$ irregular còncau (dreta)

Figura 117. Representació d'un hexàgon regular dividit en triangles equilàters

Figura 118. Representació de formes hexagonals a la natura: facetes de l'ull d'un insecte (esquerra), ruscs d'abelles (dreta)

Figura 119. Representació de l'estructura tridimensional del carboni 60 (imatge proporcionada per www.pdm.com.co)

Figura 120. Imatge d'un mosaic romà en Carranque: La Casa de Materno (proporcionada per flickr.com)

Figura 121. Xarxes de tessel·les d'un sol polígon: triangle equilàter (esquerra), quadrat (centre) i hexàgon regular (dreta).

Figura 122. Xarxes de tessel·les amb formes de diferents polígons regulars

Figura 123. Representació dels eixos de simetria d'un triangle equilàter ... 
Figura 124. Representació dels eixos de simetria d'un quadrat.

Figura 125. Representació d'un angle central.

Figura 126. Representació d'un sector circular

Figura 127. Representació dels dos segments circulars d'un cercle determinats per la mateixa corda.

Figura 128. Representació d'una corona circular

Figura 129. Representació de dos plans secants

Figura 130. Representació de dos plans paral·lels no coincidents.

Figura 131. Representació de dos plans paral·lels coincidents

Figura 132. Representació dels elements d'un angle díedre.

Figura 133. Representació d'un angle políedre

Figura 134. Representació d'una xarxa de triangles equilàters (esquerra) i una selecció de sis (dreta)

Figura 135. Representació de la construcció d'un icosàedre regular

Figura 136. Representació de la construcció d'un octàedre regular

Figura 137. Representació de la construcció d'un tetràedre regular.

Figura 138. Representació d'una xarxa de quadrats

Figura 139. Representació de la construcció d'un cub

Figura 140. Representació de la construcció d'un dodecàedre regular ........

Figura 141. Representació de prismes de diferents bases

Figura 142. Representació d'un prisma oblic

Figura 143. Representació del desenvolupament pla d'un prisma regular hexagonal (imatge proporcionada per narceaeduplastica.weebly.com)..

Figura 144. Representació d'un ortòedre

Figura 145. Representació d'una piràmide quadrangular recta (esquerra) i d'una obliqua (dreta)

Figura 146. Representació del desenvolupament pla d'una piràmide regular quadrangular

Figura 147. Representació d'un tronc de piràmide regular hexagonal .........

Figura 148. Representació d'un cilindre circular recte i el seu desenvolupament pla

Figura 149. Representació d'un cilindre oblic

Figura 150 Representació d'un cilindre el·líptic

Figura 151. Representació d'un con circular recte i el seu desenvolupament pla....

Figura 152. Representació d'un con oblic

Figura 153. Representació d'un tronc de con recte i el seu desenvolupament pla.....

Figura 154. Representació d'un casquet esfèric

Figura 155. Representació d'una zona esfèrica

Figura 156. Representació d'un tascó esfèric

Figura 157. Representació de dos triangles homòlegs per una translació ...

Figura 158. Representació de dos triangles homòlegs per un gir

Figura 159. Representació de dos triangles homòlegs per una simetria central (gir de $180^{\circ}$ ).

Figura 160. Representació de dos triangles homòlegs per una simetria axial 
Figura 161. Representació de dos composicions de simetries axials. eixos paral·lels (esquerra) i eixos secants (dreta)

Figura 162. Representació geomètrica del teorema de Tales

Figura 163. Representació de dos pentàgons homòlegs per una homotècia de raó positiva

Figura 164. Representació de dos pentàgons homòlegs per una homotècia de raó negativa

Figura 165. Representació de dos triangles semblants

Figura 166. Representació de dos prismes triangulars homòlegs per una simetria especular

Figura 167. Representació d'un sistema tridimensional d'eixos

Figura 168. Representació de les nocions d'orientació estàtica en el cos d'un nen

Figura 169. Taller de Topologia 2 (fabricat per Nathan)

Figura 170. Imatge infantil nocturna d'uns animals de granja

Figura 171. Imatge de xiquets davant i darrere d'un arbre

Figura 172. Imatge d'un rogle de xiquets i xiquetes (esquerra)

i la representació simbòlica de la posició «al voltant de» (dreta)

Figura 173. Pistes màgiques 1 i 2 (fabricat per Nathan).

Figura 174. Representació de les malles de tres geoplans: quadrangular (esquerra), triangular (centre) i circular (dreta).

Figura 175. Representació d'un trajecte elaborat amb elàstics en un geoplà

Figura 176. Representació de la reproducció d'un ordre lineal directe

Figura 177. Representació de la reproducció d'un ordre lineal en horitzontal a un altre en vertical

Figura 178. Representació d'estrelles per reproduir un ordre cíclic

Figura 179. Representació d'una caixa amb indicacions de l'espai que ocupa i d'un punt, una línia, i la superfície d'una de les seues cares .....

Figura 180. Representació d'una línia tancada (esquerra) i d'una oberta (dreta)

Figura 181. Representació d'una superfície tancada (esquerra) i d'una oberta (dreta)

Figura 182. Representació d'una superfície toroïdal

Figura 183. Representació de fronteres en línies....

Figura 184. Representació de la posició d'un jugador dins del camp de bàsquet però fora de l'àrea de tir

Figura 185. Representació de fileres rectes i corbes de nens i nenes

Figura 186. Representació de la vista superior de fileres rectes i corbes.....

Figura 187. Representació de la vista frontal de fileres rectes i corbes .......

Figura 188. Representació amb petjades d'un recorregut recte (esquerra) i d'un de corb (dreta)

Figura 189. Representació d'un llapis en posició vertical, obliqua i horitzontal

Figura 190. Representació de nusos determinats per dues línies simples (esquerra) i per una no simple (dreta) 
Figura 191. Representació d'un plànol de la ciutat de Castelló amb un recorregut assenyalat....

Figura 192. Representació d'una circumferència i d'un cercle

Figura 193. Figures geomètriques planes (Geometric shapes, fabricat per Ness Arnold Ltd.).

Figura 194. Representació del contorn d'un triangle i un quadrat i de les figures corresponents

Figura 195. Figures Geomètriques en l'entorn (fabricat per Akros).

Figura 196. Géométrix (fabricat per Nathan)

Figura 197. Representació d'imatges simètriques en objectes i figures planes

Figura 198. Caras en simetría (fabricat per HenBea, esquerra) i Symétricolor (fabricat per Nathan, dreta)

Figura 199. Representació en una quadrícula de la meitat d'una imatge simètrica

Figura 200. Mosaic Múltiple (Playshapes, fabricat per Invicta Plastics Ltd.)

Figura 201. Tangram (fabricat per Diset, esquerra) i algunes imatges fragmentades per compondre-les (dreta)

Figura 202. Representació de dues sanefes. 